\title{
Republic of Madagascar: Poverty Reduction Strategy Paper Annual Progress Report
}

Poverty Reduction Strategy Annual Progress Reports (PRSPs) are prepared by member countries in broad consultation with stakeholders and development partners, including the staffs of the World Bank and the IMF. Updated every three years with annual progress reports, they describe the country's macroeconomic, structural, and social policies in support of growth and poverty reduction, as well as associated external financing needs and major sources of financing. This country document for the Republic of Madagascar, dated June 2006, is being made available on the IMF website by agreement with the member country as a service to users of the IMF website.

To assist the IMF in evaluating the publication policy, reader comments are invited and may be sent by e-mail to publicationpolicy@imf.org.

Copies of this report are available to the public from

International Monetary Fund • Publication Services

$70019^{\text {th }}$ Street, N.W. • Washington, D.C. 20431

Telephone: (202) 623-7430 • Telefax: (202) 623-7201

E-mail: publications@imf.org • Internet: http://www.imf.org

Price: $\$ 15.00$ a copy

\section{International Monetary Fund Washington, D.C.}



Republic OF MAdagascar

TANINDRAZANA - FAHAFAHANA - FANDROSOANA

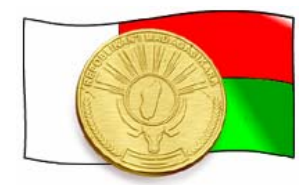

Poverty Reduction Strategy Paper
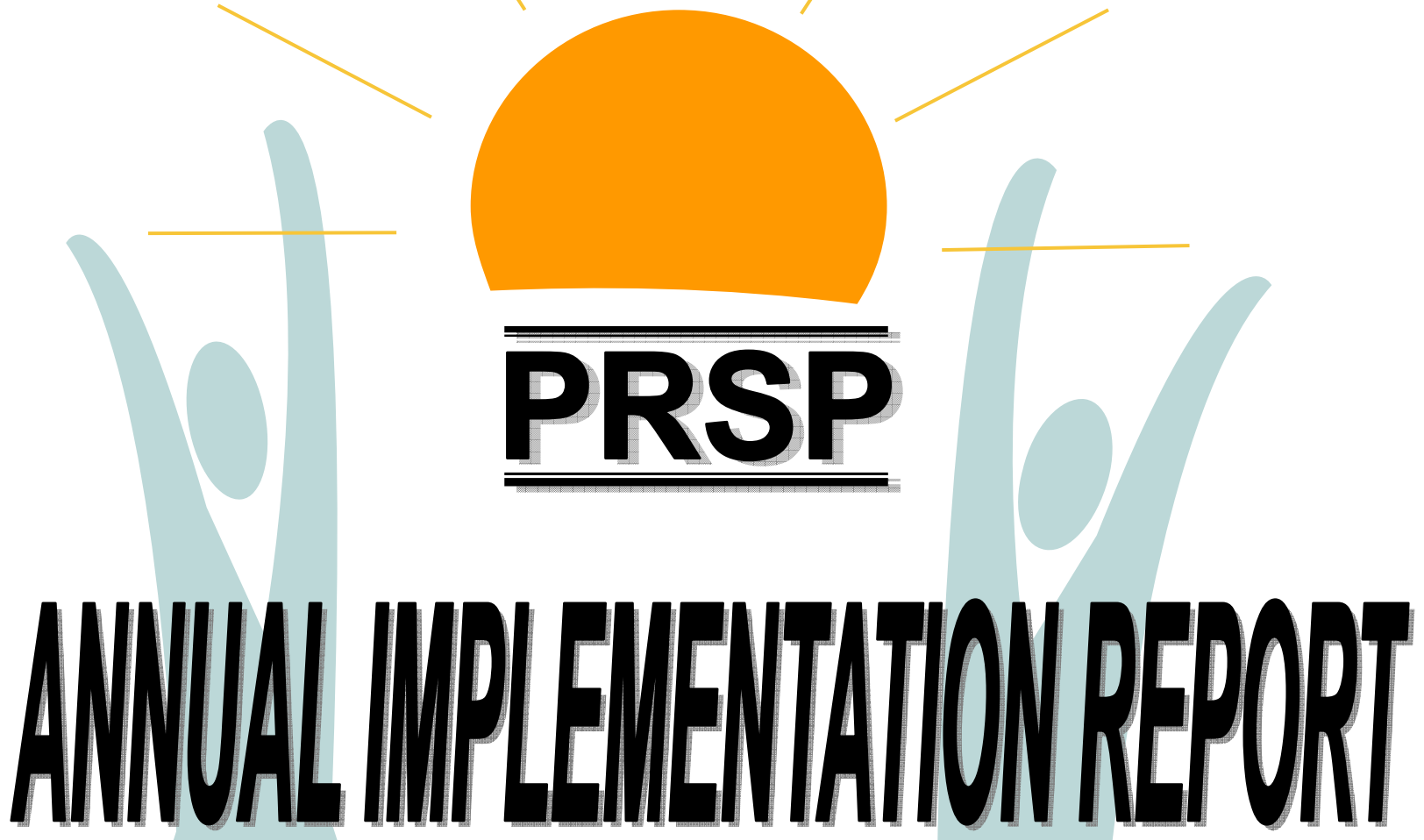

\section{January - December 2005}




\section{TABLE OF CONTENTS}

EXECUTIVE SUMMARY

1. INTRODUCTION

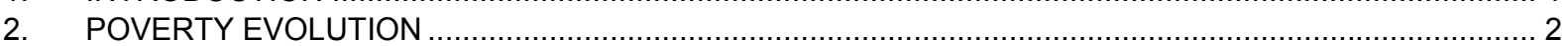

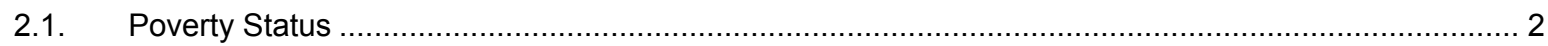

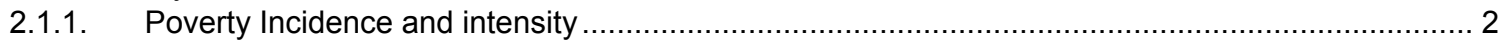

2.1.2. Poverty Indicators according to household characteristics ..................................................... 3

2.2. Opinions expressed by households about their living conditions .............................................. 4

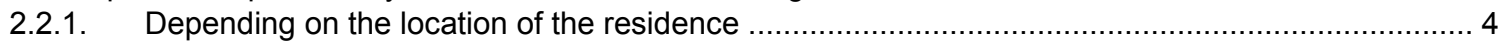

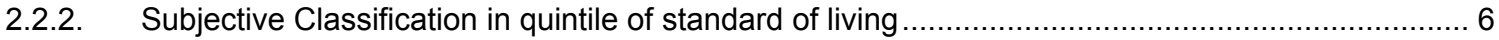

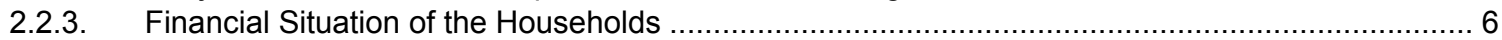

2.2.4. Evolution of the Standard of living for the last year........................................................ 7

2.2.5. The Opinion of Households regarding the Future of the Country .......................................... 8

2.3. Evolution of main indicators for monitoring of poverty ......................................................... 10

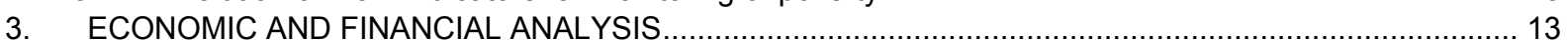

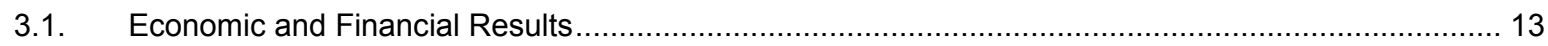

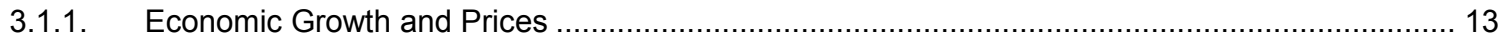

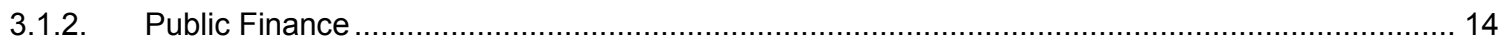

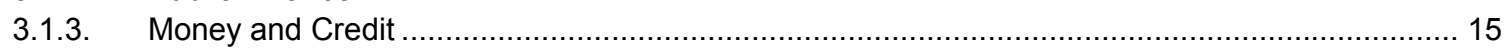

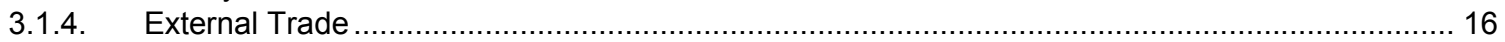

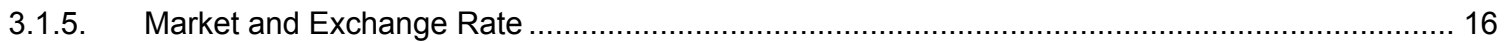

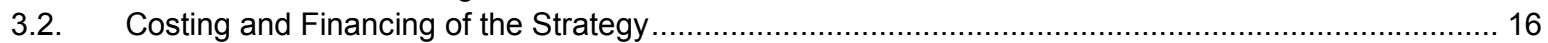

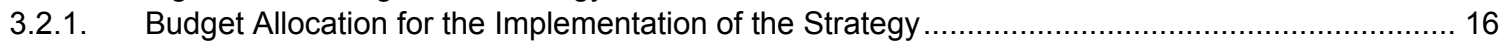

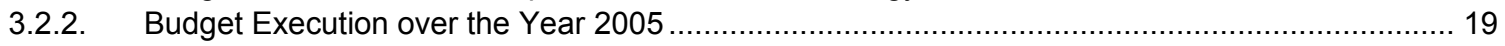

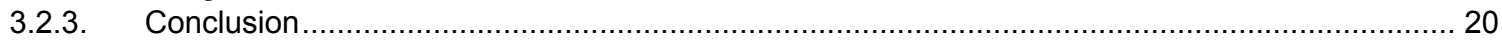

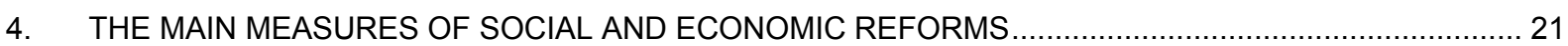

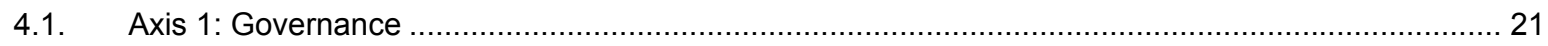

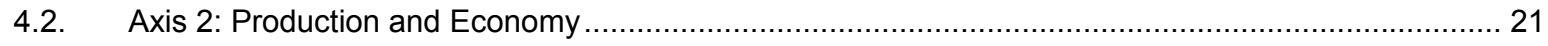

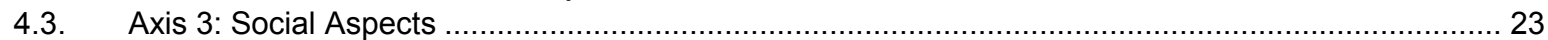

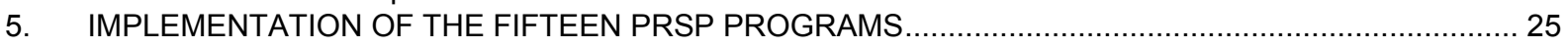

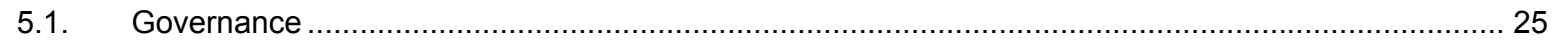

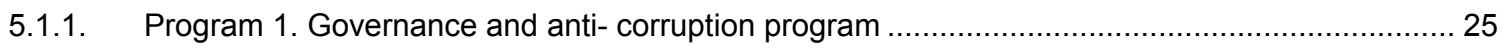

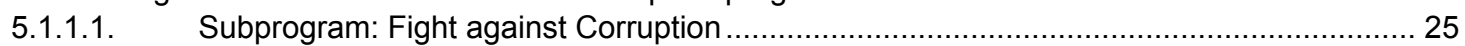

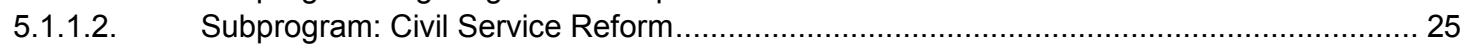

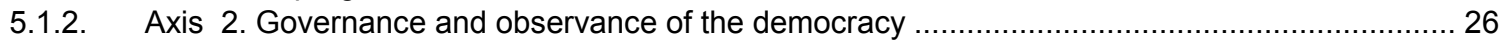

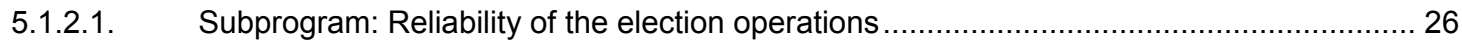

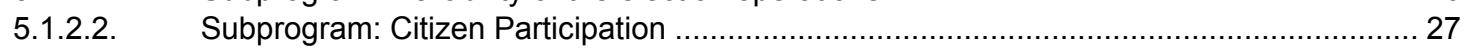

5.1.3. Program 3. Governance and legally constituated state .................................................... 28

5.1.3.1. Subprogram: Rationalize the Processing of administrative activities and implementation of

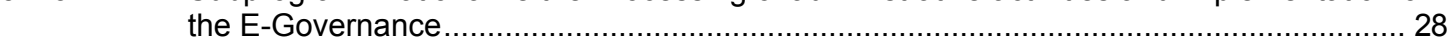

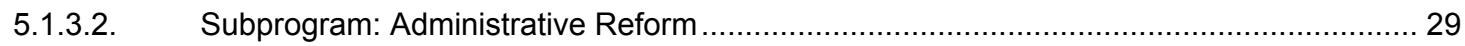

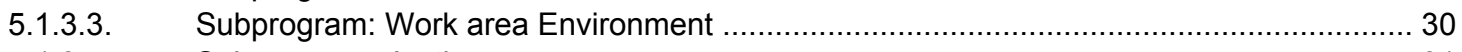

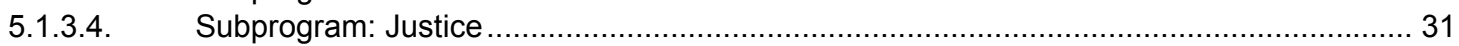

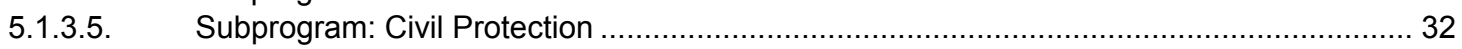

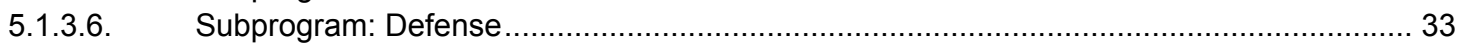

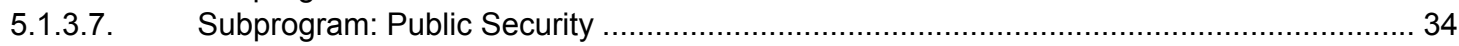

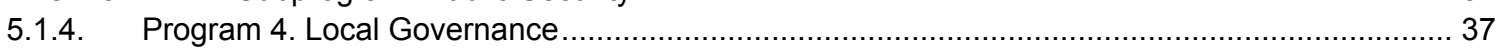

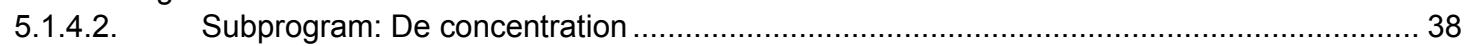

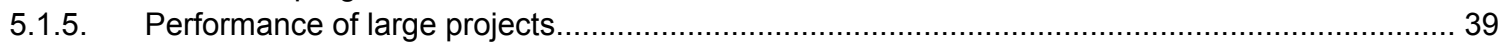

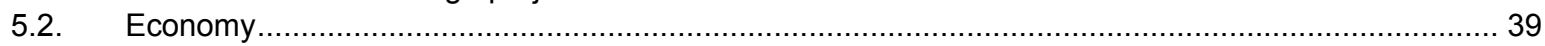

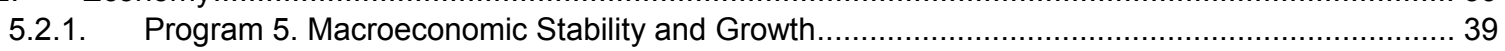

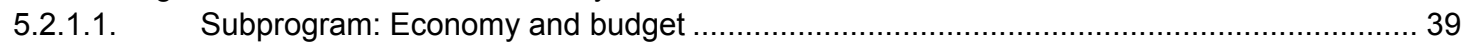

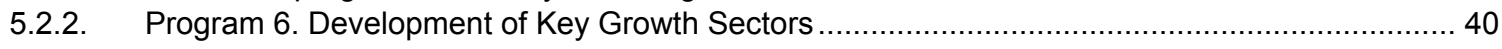

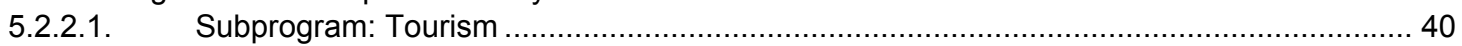

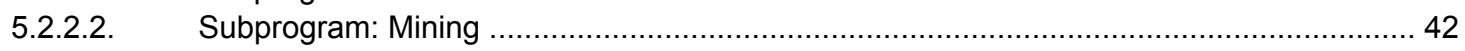

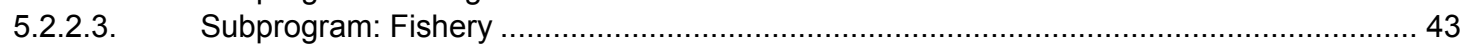

5.2.2.4. Subprogram: Manufacturing Industries ........................................................... 43

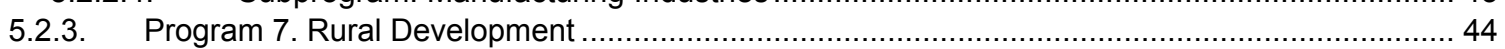

5.2.3.1. Subprogram: Agriculture and Livestock .......................................................... 44

5.2.3.2. Subprogram: Environment, Water, and Forests.................................................. 46

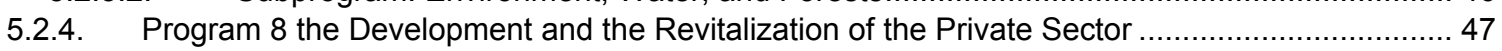


5.2.5. Program 9. Development and Intensification of Structuring Infrastructure ............................ 48

5.2.5.1. Subprogram: Transports, Roads, and Meteorology ............................................. 48

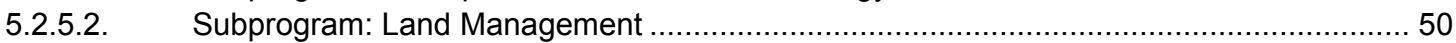

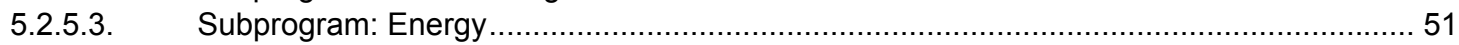

5.2.5.4. Subprogram: Post, Telecommunication and Communication ...................................... 53

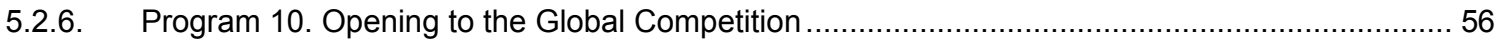

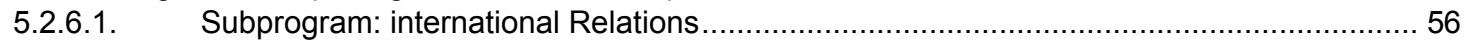

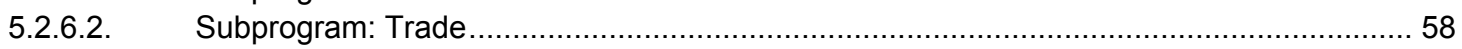

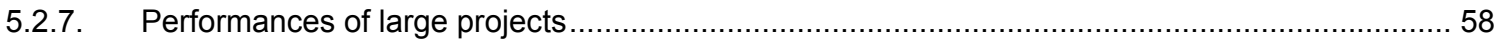

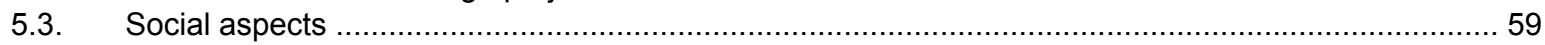

5.3.1. Program 11. Development of educational level of the population and the research ....................5 59

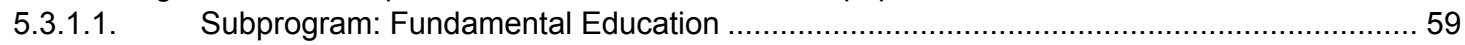

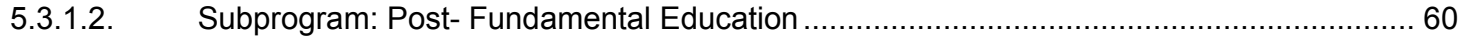

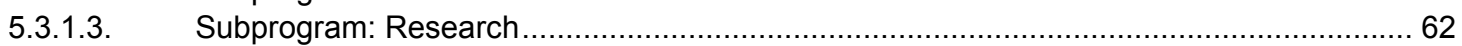

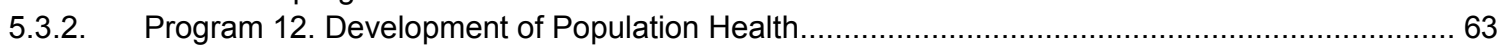

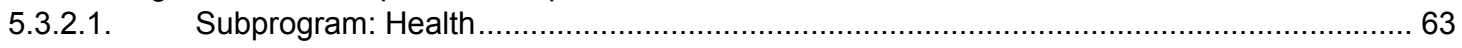

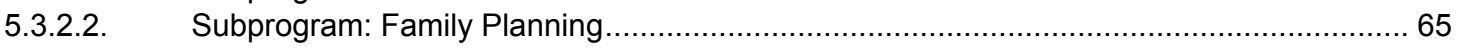

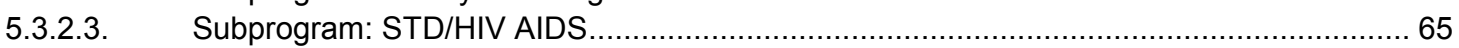

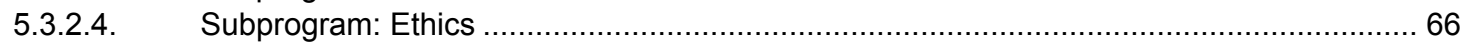

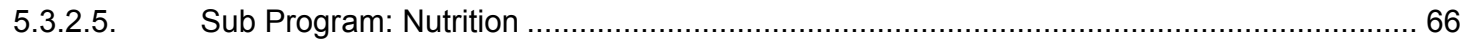

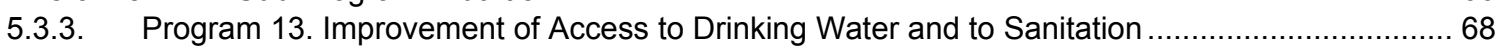

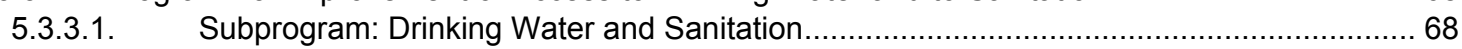

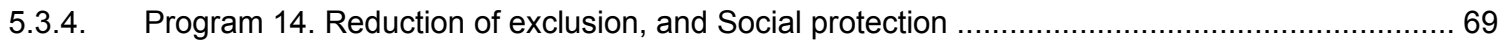

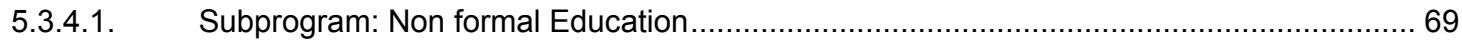

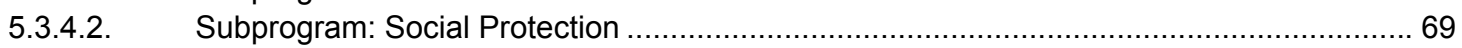

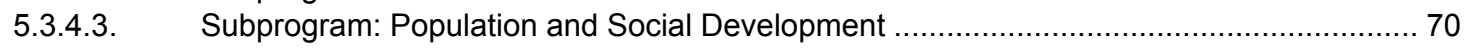

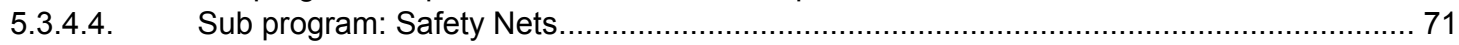

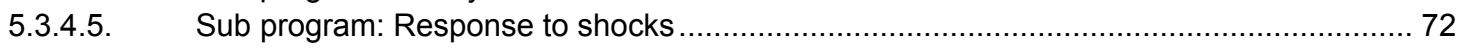

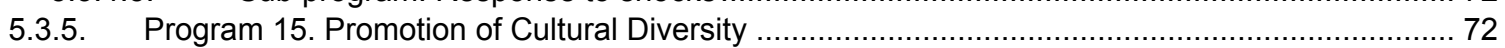

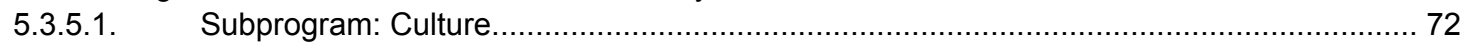

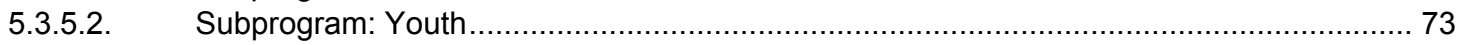

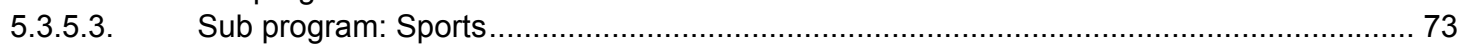

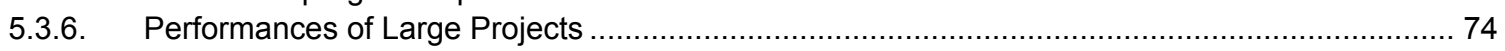

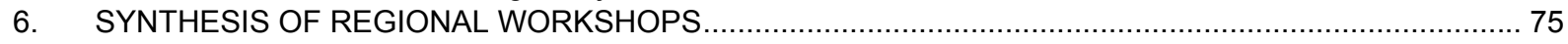

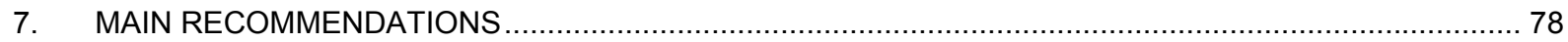

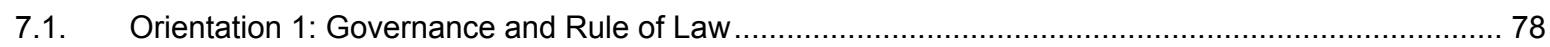

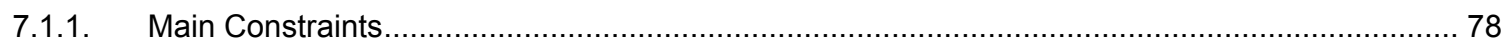

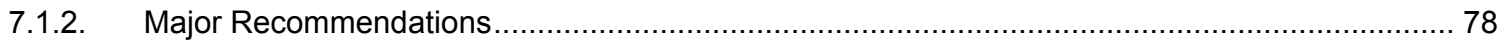

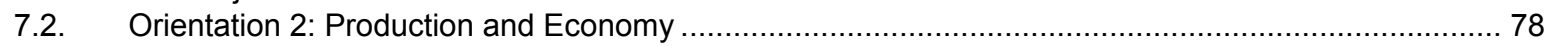

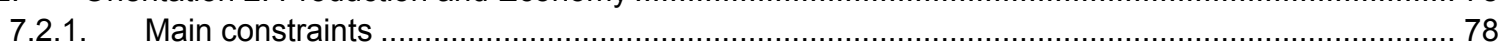

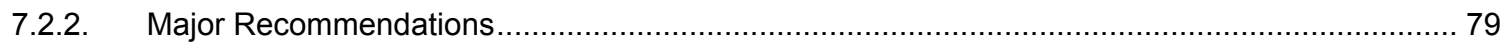

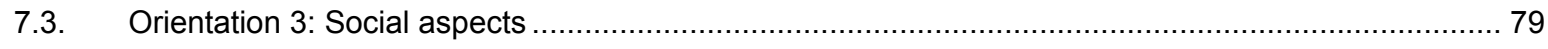

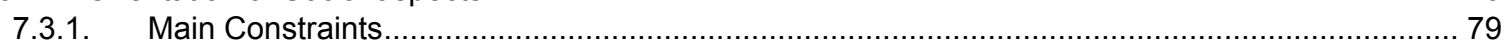

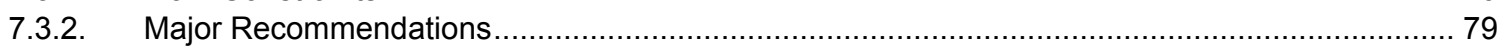

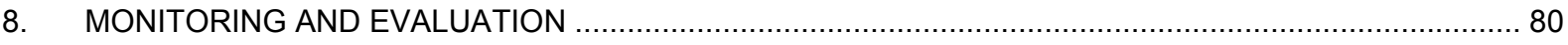

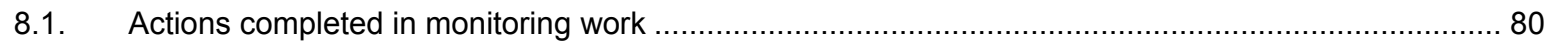

8.1.1. Actions undertaken by the Government (Presidency, Prime Minister's office, Technical Secretariat

to Adjustment, INSTAT, Directorate General of Planning, Ministries): ............................................ 80

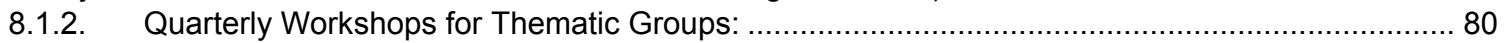

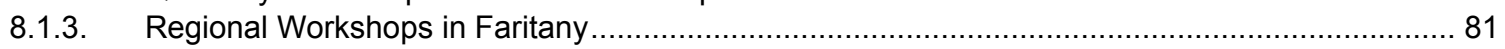

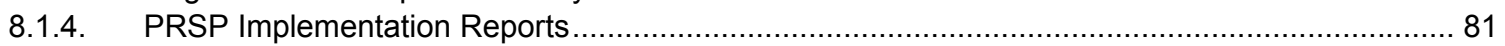

8.2. Having an Operational PRSP Implementation Monitoring System ......................................... 81

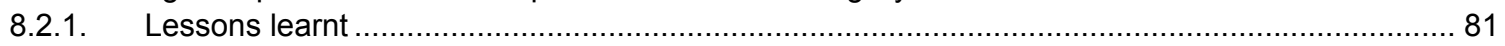

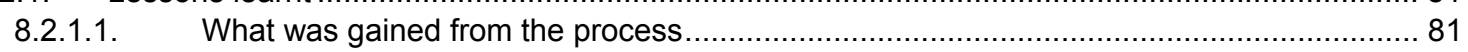

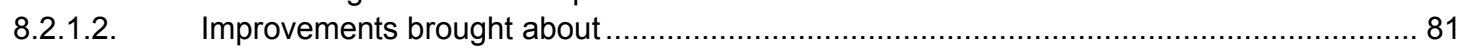

8.2.1.3. Implementing the PRSP at regional level: stakes and challenges .............................. 81

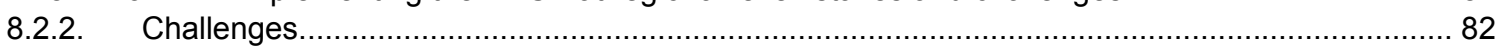

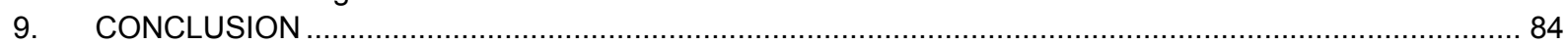




\section{LIST OF TABLES}

Table 1: Spatial Poverty Profile in Madagascar in 2005 (\%) ................................................................. 2

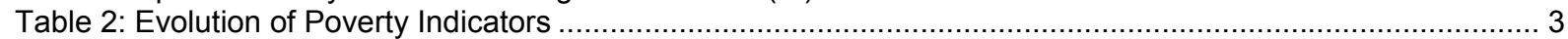

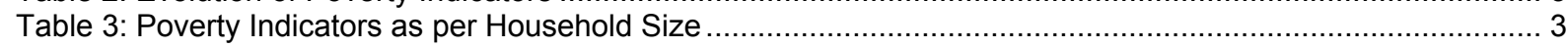

Table 4: Poverty Indicator as per Socioeconomic Groups ........................................................................ 4

Table 5: Poverty Indicators as per household head gender ...................................................................

Table 6: Household Opinions on their own standard of living as per residence location ................................... 5

Table 7: Household Opinions on their own standard of living as per regions …......................................... 5

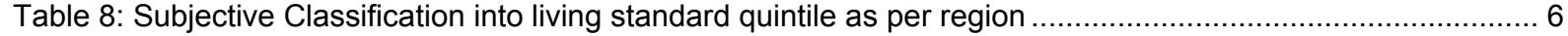

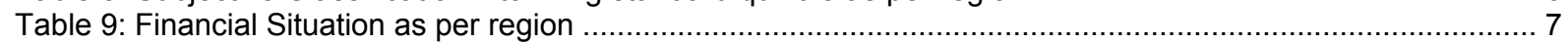

Table 10: Living Standard Evolution in the course of last year .............................................................. 8

Table 11: Household distribution as per opinion on the country's future, per "quintile"..................................... 9

Table 12: Household Distribution as per opinion on the country's future, per region ........................................ 9

Table 13: Household Distribution as by the opinion on the country's future, as by the education level of family head

Table 14: The 31 indicators for PRSP Monitoring.....

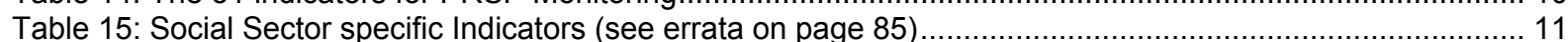

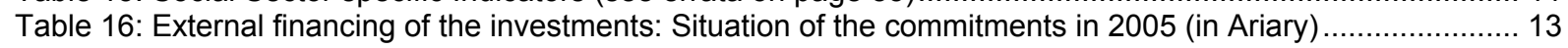

Table 17: Resources and uses of the GDP in current francs (of billion Ariary) .............................................. 14

Table 18: Financial transactions of the central Government (in billions of Ariary and in \% the GDP) ....................15

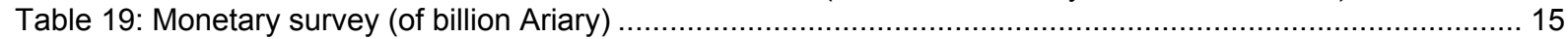

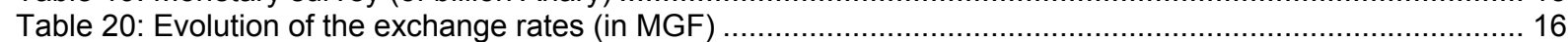

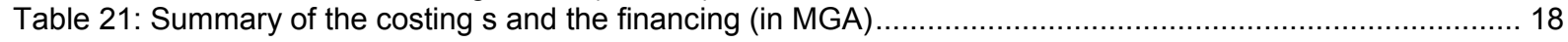

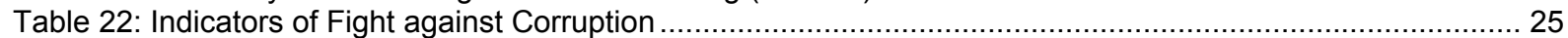

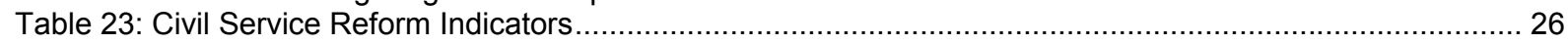

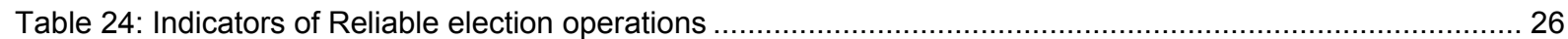

Table 25: Indicators of Citizen Participation ................................................................................... 27

Table 26: Indicators of Rationalization of the processing of the Administrative Activity and the implementation of

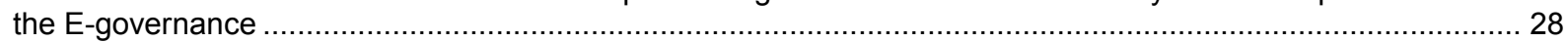

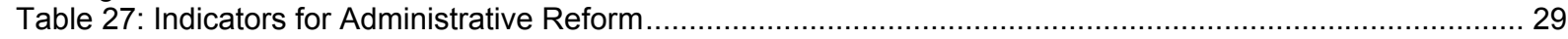

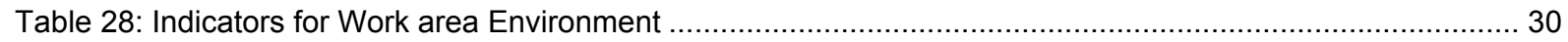

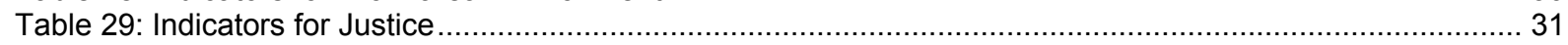

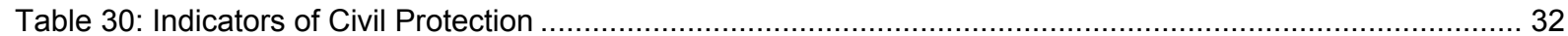

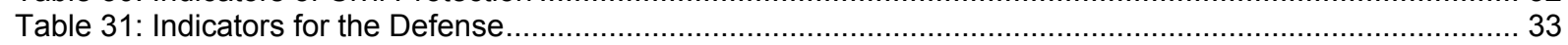

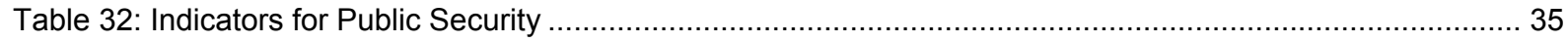

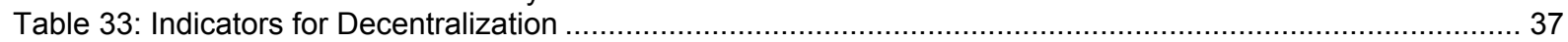

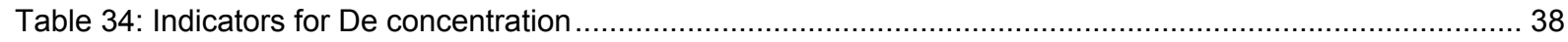

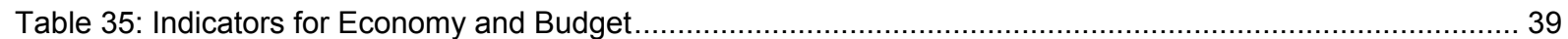

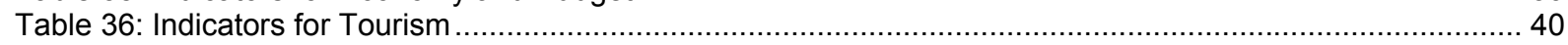

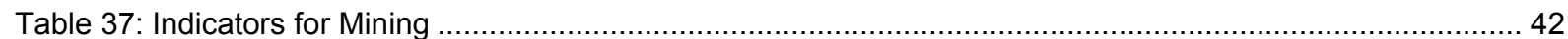

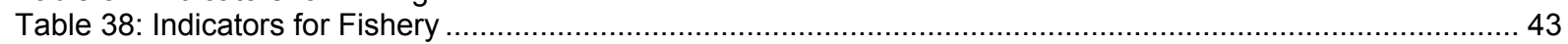

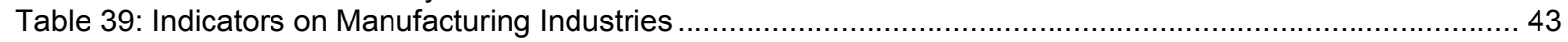

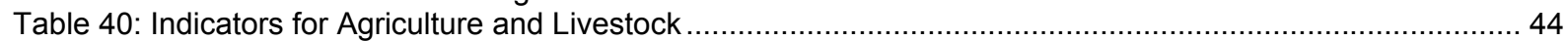

Table 41: Indicators for the Environment, Water and Forestry .............................................................. 46

Table 42: Indicators for Industry, Trade, and Development of the Private Sector.........................................4 47

Table 43: Indicators for Transports, Roads, and Meteorology .............................................................48

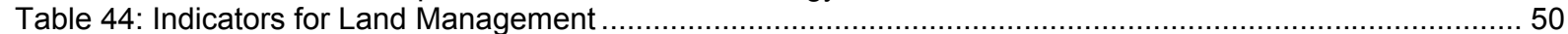

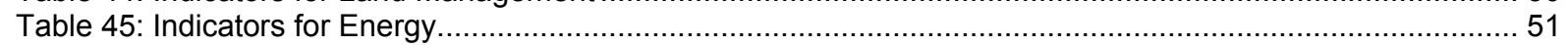

Table 46: Indicators for Post, Telecommunication and Communication ....................................................... 53

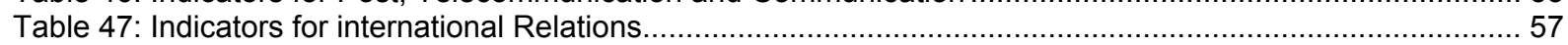

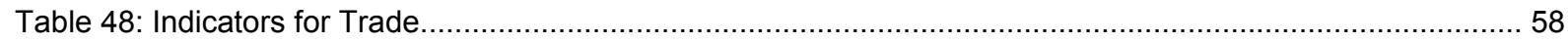

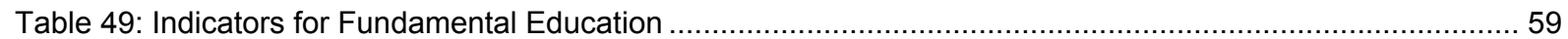

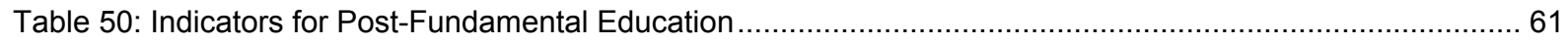

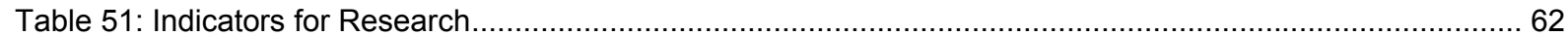

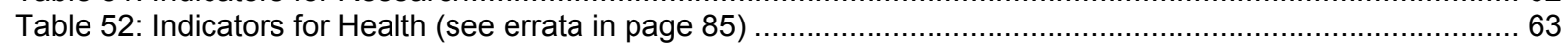

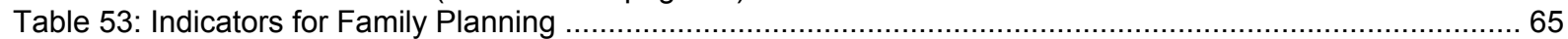

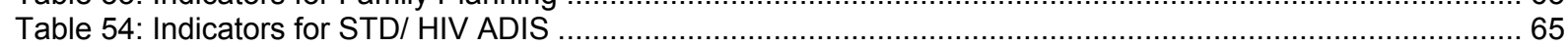

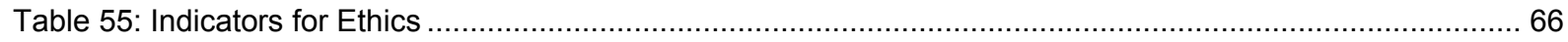

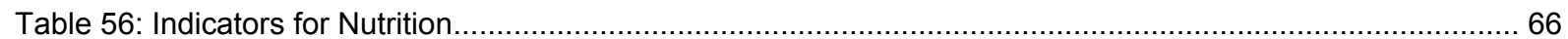

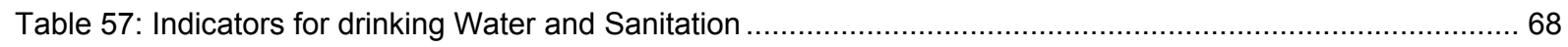

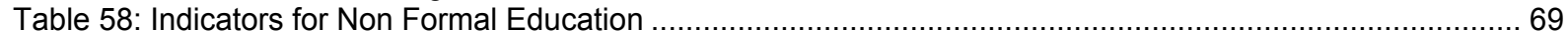

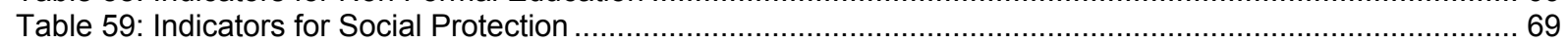

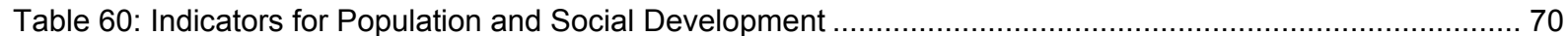

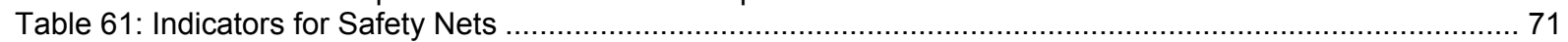

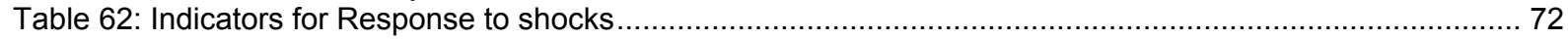

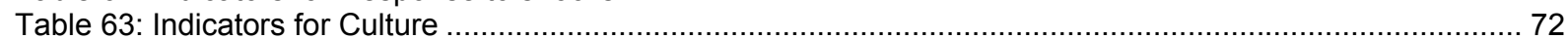

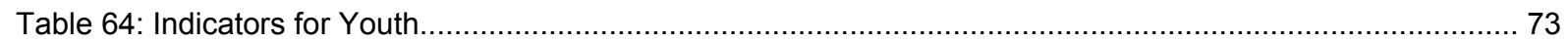

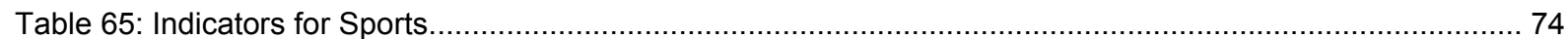




\section{EXECUTIVE SUMMARY}

\section{Introduction}

In June 2005, the PRSP was updated to take account of the new strategic and policy orientations included in the Vision Madagascar Naturally (Madagascar Naturellement) and government policy (la Politique Generale de L'Etat - PGE). At the institutional level, the 22 Regions were established and program budgets were implemented.

Monitoring of PRSP implementation is coordinated and facilitated by the Technical Adjustment Secretariat, the secretariat to PRSP Technical Unit, following a participatory process, with the organization of thematic workshops on a quarterly basis at the national level, and technical meetings at the regional level every six months. Implementation reports were produced regularly every six months and annually since July 2003.

Fifteen programs are identified in the updated PRSP for implementing the poverty reduction strategy and to serve as the basis for monitoring. These programs are subdivided into sub-programs and include specific indicators and actions, followed by interim indicators.

The present report relates to monitoring of the PRSP implementation for the year 2005 with the objective of providing information on the evolution of poverty and on the poverty monitoring indicators. Furthermore, it provides analyses on the achievements completed, results obtained and the evolution of indicators compared to the defined objectives. The results of the data analysis will serve to formulate recommendations for the ministry officials and their programs. In addition, they will serve as decision making tools for the country leadership in orienting and adjusting the strategies, policies, programs and actions, in line with the fight against poverty.

\section{Poverty Status and Poverty Indicator Analysis}

In 2005 , the incidence of poverty incidence decreased to $72.1 \%$ from $68.7 \%$ in 2004 . The phenomenon of poverty is more pronounced in rural areas with a poverty rate of $75.3 \%$ compared to $52 \%$ in urban areas. The regions on the East coast of the country, namely Atsimo Atsinanana, Vatovavy Fitovinany, and Androy are the ones most affected by poverty, with rates close to $80 \%$. Among the rural regions, those of Analamanga, Boeny and Alaotra Mangoro are the least poor ones.

Economic growth occurring between 2004 and 2005 benefited both rural and urban populations but the impact is more significant in rural areas which benefited from an increase in the producer price of food items. Urban areas were much more affected by the significant price increases.

Regarding the opinion of households on their living conditions, almost half of the population state they are in difficulty, especially in rural areas. Concerning the evolution in the standard of living of individuals in the last year, $41 \%$ of households affirm that their status had deteriorated and more than $40 \%$ declared a status quo. As for optimism regarding the future of the country, a slight decrease is noted in the "rate of optimism" between 2004 and 2005. The percentage of households that are optimistic about the future of the country increases with the consumption quintile and the education level of the head of the household.

\section{Economic and Financial Analysis}

\section{Economic and Financial Results}

In 2005, the economic growth rate is $4.6 \%$ against a projection of a $7 \%$. Power outages, as well as the dismantling of the Multi Fiber Agreement, had harmful consequences on activities of enterprises. Growth was driven by private investment, which was $12.3 \%$ of GDP compared to $12.2 \%$ last year. The tertiary sector is the one that contributed the most to GDP growth, with a $6.1 \%$ increase in production.

The rate of inflation is $11.5 \%$ in 2005 whereas 2004 recorded a high increase in consumer prices of about $27 \%$ year-on-year. Relative stability is noted for prices and the exchange rate due to a tight monetary policy in conjunction with a decrease in the price of rice.

At the end of 2005, the national currency depreciated by about $7.2 \%$ against the Euro and the dollar, while in 2004, the depreciation was about $67 \%$ and $53 \%$ respectively. As a matter of fact, the establishment of the continuous MID (foreign exchange inter-bank market) in 2004 is starting to yield consequential results. However, the currency supply is still insufficient.

Export revenues recorded a $20.7 \%$ decrease in SDR terms compared to 2004 . The main underlying causes are the dismantling of the Multi Fiber Agreement and the decline in the export price of vanilla. Similarly, imports decreased compared to last year after the removal of detaxation on capital goods and the decrease in the imports of consumption goods. The ratio of revenue to GDP is $10.1 \%$ and has not improved compared to 2004 despite efforts to improve collection and strengthened measures. 
In terms of expenditures, the ratio of total expenditures to GDP declined to $21.2 \%$ in 2005 compared to $25.9 \%$ in 2004 and the budget deficit on a commitment basis is $-4.7 \%$ of GDP versus $-5.1 \%$ of GDP last year.

\section{Strategy Costs and Financing}

In the course of the year 2005, the total cost of implementing the strategy, measured by total non salary expenditures amounts to 1,437 billion Ariary of which $16 \%$ is for governance, $58 \%$ is for economic growth, and $26 \%$ is for social protection, human and material security.

The commitments of non salary expenditures were provisionally estimated at $97.3 \%$ of resources planned for the year 2005.

The expenditures planned to support the governance axis were committed up to $96.9 \%$ of the open credit amount. The local governance program distinguishes itself from the other programs with a commitment rate of $107.5 \%$ due to the good performance of the development activities in communes and regions $(176.2 \%)$, and the improvements in budget management and accounting of local governments $(99.8 \%)$.

The axis of economic growth with a broadened social basis for which resources were committed up to $108.8 \%$ of the open credit amount benefited from the strong contribution of almost all the programs supporting the strategy: development of key growth sectors, rural development, private sector development, and the development of infrastructure.

The axis of social protection, human and material security performed less well with a commitment rate provisionally estimated at $71.5 \%$ of the open credit amount in 2005 . The contribution was stronger for the three sub-programs of social protection, human and material security, and valorization of cultural diversity.

\section{Implementation of the Fifteen PRSP Programs}

\section{Governance}

On the Governance and Anti-corruption Program, regarding the fight against corruption in 2005, the CSLCC (Council for the fight Against Corruption) and BIANCO (National Independent Bureau Against Corruption) collaborated together to establish the anti-corruption strategy which was oriented towards expanding economic sectors.

For civil service reform, the operation VOY RINDRA related to the classification of posts, the harmonization of treatments and the setting up of a skill database was launched.

On Democracy, the actions related to making electoral operations reliable are under way through the establishment of non-mandatory rulings and the preparation of election lists. The decree setting up the organization and the modalities of functioning of the National Election Council [Conseil National Electoral (CNE)] is adopted. Regarding participation for citizen life, civic education programs have been conducted and the journalists have been trained.

Rule of Law Program, concerning civil protection, contingency plans have been made available to the Regions, to the Communes, and to the Districts, as well as risk and disaster management committees to reduce the population vulnerability during cyclones. Administration functioning has been improved due to the establishment of a manual of procedures, improvement of the means of working, as well as computerization of the working system.

As regards to work environment, the National Employment Policy was adopted and the National Monitoring Committee for the National Employment Policy and Poverty Reduction has been set up and is operational.

Regarding security and defense, the strengthening of material means and capacities had some positive results. The crime rate has manifestly decreased. The same applies to offences on immigration and emigration, arms, drugs and alcohol traffic, road insecurity and people safety. The confidence rate among the rural population has improved, and the crime rate decreased.

In the justice area, Administrative and Financial Courts have been set up in the 6 main towns of province (Faritany), along with the decentralization effort and the effective budget control and legality. The actions of controls have been intensified in 2005 in keeping with corruption prevention. Concerning the procedures, the pending cases have been cleared among the lower Courts of Antananarivo, Toamasina, Fianarantsoa, and Antsiranana, leading to positive results (96\%). However, ambulant hearings held are still insufficient.

Concerning Local Governance (gouvernance de proximité), the consolidation of the decentralization process is effective through the capacity building of officials in the regions and communes on leadership, management, and regional planning. Financial resources allocated to 
communes have been enhanced. In terms of deconcentration, the services of the administration are currently effective across the whole national territory.

\section{Economy}

On Macroeconomic Stability and Growth, the growth objective has not been reached. We notice also the low performance of the tax revenue to GDP ratio. Issues in power outages, the cash flow problem in JIRAMA, and oil price increase have much disrupted the economic activity. Some measures have been taken in such a situation to reduce the deficit in public expenditures. Concerning JIRAMA, the actions undertaken were relative to the preparation of the implementation of the management contract with Lahmeyer and the elaboration of the recovery plan with the development of an investment plan in the short, medium and long term. However, the Government abided by its commitments in terms of the poverty reduction strategy by allocating significant budgets to the Ministry of Education and the Ministry of Health, which are among the priority sectors in poverty reduction.

On the development of expanding sectors, in tourism, boosting of the promotion of the destination to Madagascar, along with the identification of new tourist sites and the creation of new infrastructure had positive results with an increase in operational rooms, new jobs created, as well as increase in tourist arrivals and generated foreign exchange revenues. Furthermore, actions in standardization, labeling, and certification of the hotel facilities are under way in several sites.

For the mining sector, the amounts of investment in mining, the collection of mining royalties and mining exports increased. Such results are the results of awareness raising and sensitization actions conducted among the operators, and of the reinforcement of transparency and good governance. Concerning the reduction in mineral substance smuggling, controls and unexpected visits allowed seizing an important quantity of substances.

For fishery, the amount of fishing and aquaculture royalties recorded a very important increase of $64 \%$ between 2004 and 2005, exceeding the annual objective of $2 \%$, thus contributing in soaring catches in 2004 , the high number of licenses issued and the impact of publications of permit and royalties status on a six months basis.

On manufacturing industries, the dismantling of the Multi Fiber Agreement provoked a regression in the number of authorized Export Processing Zone enterprises. The consequences of malfunctioning problems due to power outages during the year 2005 are also noted. Conversely, the investment objectives in Export Processing Zone firms were achieved with the creation of 9,335 jobs.

Rural Development Program, in the agriculture area, results are satisfactory. The fulfillment of agriculture contests, the rehabilitation of hydro agricultural networks and resorting to credit and financing enabled positive results for the agricultural output (3\% to $6 \%$ ), and agricultural production also increased. Conversely, the growth rate of the value of export on agricultural product decreased due to decrease in shrimp catch. As regards land tenure, the objectives in land titling are almost achieved. In livestock, the vaccination rate for cattle against anthrax is achieved at $78 \%$.

In the area of environment, water, and forest, the objectives defined for the year 2005 are achieved. Strengthened good governance is undertaken through actions for monitoring and repressing infractions. The achievement of a communication campaign in the main towns of the province (Faritany) contributed to the creation of 5 new protected areas having a provisional status and an area of $1,050,000$ ha. The setting up of $6 \mathrm{MECIE}$ resource centers (process to make investments compatible with the environment Mise en Compatibilité des Investissements avec l'Environnement (MECIE)), contributed to achieving the objectives in the issuance of environment permits (35). Regarding the burnt areas, deserving communes were granted bonuses, providing positive results. Indeed, the areas destroyed by fire decreased by $17 \%$ compared to 2002 .

Developing and Boosting the Private Sector, in the area of industry, trade, and private sector, actions for securing investment, promoting investment, developing partnerships in Madagascar produced positive results. The investment rate is $12.37 \%$ out of an objective of $14 \%$. At GUIDE, the objectives in firm setup are exceeded (882 out of 820 ). Conversely, some delay was recorded in the execution of the program for developing and boosting the private sector due to a procedure problem in the recruitment of officials. As regards trade, a decrease in export values was recorded due to decrease in the exports of some main products (vanilla, textile products).

On the development and the intensification of structuring infrastructures, the achievements in the rehabilitation of rural roads have improved compared to those of 2004 but the objectives for the year are not achieved (65\%). As for national roads, results have recorded decreases compared to 2004, and the objectives are half reached. Such results in general are related to constraints in redeployment of personnel, expenditure regularization, restructuring of the Sector Transport Program (PST) and the increase in prices of cement and laminates. Conversely, positive results were recorded 
regarding maintenance of road networks and construction works as a whole. Reform in the transport sector is achieved at $65 \%$, the autonomous management of the port is established, and the port concession management is under way. For the sector of meteorology, net progress is recorded compared to results in 2004 on the rehabilitation and the modernization of physical infrastructure, close to $75 \%$ at end 2005 .

For territory management, the satisfaction rate among population towards the services provided is satisfactory Territory management tools were made available to decentralized Local Governments and the town planning were completed by observing procedures. The elaboration of the scheme for regional development is postponed to 2006.

In the area of energy, results are satisfactory as regards to the establishment of the institutional and organizational reform in the sector. In 2005 , the electricity access rate was $25.31 \%$ and the objectives in terms of number of electrified villages are not achieved. The sector is facing a problem of financing and equipment clearance.

In posts and telecommunication, for the postal service, the number of savings "Tsinjolavitra" recorded a net improvement compared to the previous year. In telecommunication, the production center for feeding sixteen remote centers is operational and the computer equipment for equipping them is acquired. In keeping with the setting up of the National Optic Fiber Backbone, the work has started. The pilot site "Government Intranet" is starting off at the Ministry of Telecommunication, Post and Communications. Furthermore, the State portal site is developed on line. For communication, results are satisfactory as to extension and modernization of the Radio Television station. To improve the quality of produced programs, RNM (National Malagasy Radio) and TVM (National Television Chain) were equipped with digital equipment in all Regions.

Regarding the opening to Global Competition, external exchanges were intensified, and Madagascar strengthened its international presence and its participation in the regional cooperation system.

\section{Social}

In the program of the development of educational level of the population and research, for fundamental education, an important number of classroom buildings were constructed. The enrolment rate clearly improved due to the reduction in schooling costs for families (school fees, kit) and among establishments (subsidy). The efforts undertaken for the development of teaching staff provided positive results in terms of the completion rate, the pupil/ teacher ratio, and the repetition rate.

In terms of development of the health of the population, regarding health, the vaccination coverage rate has improved considerably and the objectives were exceeded due to the implementation of advanced and mobile vaccination strategies in each district. Despite the efforts accomplished in the construction and rehabilitation of Basic Health Centers (CSB), it was not possible to improve the ratio of population per CSB in 2005. The objectives regarding the increased rate in curative medicine consultation in CSBs were not achieved. The objectives of the availability of drugs in the CSBs were achieved. An important number of recruitments were completed, and the objective in terms of staff coverage is achieved at $90 \%$.

Regarding family planning, actions were undertaken for having an operational new PF sites and the supply of integrated products along with essential drugs. However, the objectives in contraceptive coverage rate were not achieved.

In the fight against HIV / AIDS, the establishment of the Local anti-AIDS Council is under way, as well as sensitization among communes. All the actions planned for awareness-rising and information through television and radio broadcasting are achieved. The same applies to the management of People Living with HIVIAIDS.

In nutrition, at the institutional level, the National Nutrition Office is operational. The National Community based Nutrition Program was validated and it started as a pilot program among 110 sites. Various actions for the intensification of the fight against malnutrition, such as de-worming, Vitamin $\mathrm{A}$ and iron Supplementation enabled to improve malnutrition prevalence (underweight). Communication actions were conducted across radio and television stations to intensify access to information in malnutrition prevention.

For the program on enhancement of access to drinking water and sanitation, new construction works were set up and new latrines were built, improving the rate of access to drinking water and use of latrines.

Program for the reduction of exclusion and social protection, as regards the non informal education, the numbers of literate people increased. 
Within the domain of population and social development, the training of the responsible officials and technicians in planning, improved the planning in the approach to gender and development. Support to elderly people also improved (green cards). The number of non-mandatory rulings for birth registration increased considerably under the Program "Ezaka Kopia ho an'ny Ankizy" (EKA).

In terms of safety nets, and response to shocks, the main results are satisfactory compared to the objectives for creating part time jobs, the creation and construction of community based basic infrastructure, and the creation of income generating activities.

Program on valorization of cultural diversity, for young people, the objectives of supervising and mobilizing young vulnerable people are achieved. In sport, construction and rehabilitation of sport facilities improved the practice of sport by the population.

In the area of culture, the objectives in terms of cultural celebrations and the participation in international events are achieved.

\section{Main Recommendations}

The main overall constraints in the implementation of the programs are related to the application of the program budgets in 2005. The execution of public expenditures was delayed due to the need to appoint and train the new officials.

\section{Governance}

The level of coordination among the ministries to achieve the overall objectives is weak in terms of governance. In terms of security and defense, the financial and technical resources are insufficient to deal with the magnitude of problems of insecurity. A national security and safety policy has to be developed with the participation of all institutions and departments involved (defense, public security, justice, interior, foreign affairs ...).

The means of local governments need to be strengthened so as not to delay the decentralization/ deconcentration process. The process has to be implemented through a work plan integrating all the ministries involved.

In the area of justice, actions are to be strengthened in increasing ambulant hearings taking account of their current numbers.

\section{Economy}

Inter-ministerial coordination is weak in the implementation of economic development programs (telecommunication, agro-industry, electrification). The development of Master Management Plans provide a tool for coordinating project implementation. Furthermore, private operators capacities are to be strengthened because they are still very limited (roads, buildings, electrification).

Regarding external trade, one path is to find a solution to the dismantling of the Multi Fiber Agreement to boost the Export Processing Zones. On the other hand, actions for improving export revenues in vanilla and shrimps are necessary.

In the road and transport sector, actions must be focused on reducing isolation. The institutional reform process has to be completed so as not to hinder the activities in the sector.

Concerning post and telecommunication, the procedures for connecting rural areas have to be accelerated. Savings must be boosted to motivate savers.

In the energy sector, actions must be taken to improve the electrification rate through an increase in the number of villages that are electrified and resolving problems concerning financing and the equipment clearance.

\section{Social}

In the social sector, the sectors are mostly handicapped by the inadequacy of financial means and the needs. It is noted also that the investments in social infrastructure are not sustainable. To this end, public/private partnerships need to be strengthened.

In the sector of health, efforts have to be continued to improve the coverage of CSBs and drug availability. Family planning actions must be directed to improving the contraceptive coverage rate especially in rural and remote areas.

As regards malnutrition prevention, the integration of nutrition policy in the development programs needs to be strengthened. 


\section{Monitoring \& Evaluation System}

The monitoring of the implementation of the PRSP has evolved with the experience acquired by the Technical Adjustment Secretariat, which coordinates and facilitates the work. Regular quarterly workshops at the national level and workshops every six months at the regional level have allowed the different interlocutors of Ministries, deconcentrated services and programs to own the methodology and the operational tools.

The collection of information and the quality of the data provided by the various departments has improved, but actions to strengthen the monitoring structures and capacity of those responsible needs to be undertaken to improve the capacity for analysis in Ministries.

Efforts to harmonize and articulate the operational tools were undertaken at the national level and are worth continuing by various institutions in charge of monitoring and evaluation at national level: Prime Minister's office, STA, General Planning Directorate, Public Investment Directorate, INSTAT.

The Government working relations with the technical and financial partners for monitoring the implementation of the PRSP were formalized in a partnership framework. Periodic joint reviews between the both parties took place twice a year to discuss the level of achievements attained and the results obtained and the new orientations to take.

The plan for having an operational PRSP monitoring system at the regional level has already been proposed to regional officials. However, organizing workshops for PRSP monitoring in the regions is still difficult because the Ministries do not yet all have a Regional Directorate and monitoring structure that is operational. The actions to be undertaken for the monitoring system to be effective at the regional level are the standardization of approaches and working tools, while taking account of the specificities of each Region, the establishment of regional monitoring structures, and capacity building among officials.

\section{Conclusion}

In the course of the last three years, the PRSP implementation has left its mark on the landscape of the planning and programming process by bringing in a number of innovations in terms of conducting the development of the country by linking PARTICIPATION - PARTNERSHIP and RESULTS.

After implementing the PRSP for close to two and a half years, the following paradigms are worth highlighting:

1. The PRSP process has enabled a notable and tangible increase in the PHYSICAL and HUMAN CAPITAL of Madagascar, as many results and achievements were obtained in the country as a whole. The physical and economic infrastructure is expanding and this development contributes gradually to smoothing the deficits and imbalances within and between regions.

2. Nevertheless, despite the many achievements, the poverty reduction strategy which was conducted was not generally favorable to the poor people because the benefits of growth were rather kept by those who did not immediately need it, and this was due to a lack of targeting. This issue will have to be solved urgently so as to sustain the actions undertaken to benefit those who are truly needy.

3. Furthermore, despite the partnership process that was engaged, it seems that the contribution of the private sector as an engine of development remains relatively weak in spite of its effort in some privileged areas and sectors.

Obviously the achievements of the PRSP process will be capitalized and improved within the framework of the process of Madagascar Action Plan (MAP) which will start in year 2007. It is a question of improving in particular:

- the analysis of the public policies

- the macro-economic policy in the medium term should support the objectives of development

- the development and the coordination of the programs in order to improve their effectiveness

- the evaluation of the needs in terms of means and costing

- the prioritization of the actions of the governmental actions by taking into account the means and the risks of external shocks

- the clarification of the institutional arrangements of the system of monitoring-evaluation, and

- the reinforcement of the institutional capacities for budgetary process (formulation, execution, control) at the central, regional and communal levels. 


\section{INTRODUCTION}

\section{Context}

The President's Office of the Republic defined the Vision Madagascar Naturally in November 2004. The objectives of such a long term vision are to move from a subsistence economy to a market economy, to transform the rural economy to an industrial economy, and to increase exports. It relies on the identification and consolidation of natural riches, the development of the rural sector and the preservation of cultural values. On the other hand, the General Policy of the government was defined for the year 2005 to determine the objectives of the Government with the reinforcement of 11 fundamental programs.

The strategic and operational orientations in the Vision Madagascar and in the General Policy of the government reinforce and strengthen the development objective in the poverty reduction strategy for Madagascar to reduce poverty by half by 2015 which is included in the Poverty Reduction Strategy Paper (PRSP). On the other hand, developing the Regional Development Programs (PRD), in articulation with the PRSP, for the 22 Regions which are established, corresponds to a will by the Malagasy Government to resort to a more efficient local development approach. As regards the budget, the program budget was applied in 2005 with an emphasis on a results based approach.

The PRSP, which is the poverty reduction strategy paper of the Malagasy Government, is made up of three strategic axes and includes 15 programs to be implemented. The PRSP was updated in June 2005 and this update took into account the new orientations at the strategic, policy, institutional, and budgetary levels. It is the reference document for Madagascar's relations with its technical and financial partners.

The monitoring of the implementation of the PRSP, which started in July 2003, was conducted following a participatory and continuous process. To this end, at the central level, quarterly thematic workshops were organized on a regular basis with the participation of all development players who are: elected people, Ministries, specialized institutions, the private sector, civil society, and the technical and financial partners. This monitoring work enabled us to produce monitoring reports regularly for the implementation of the PRSP every six months and annually:

- One first interim report which was finalized in February 2004 for the period July to December 2003.

- One first annual report covering the period from July 2003 to June 2004, which was elaborated in July 2004.

- One annual report covering the whole year 2004, which was elaborated in June 2005, and a six months report of the year 2005, which was finalized in November 2005.

- A report on the regional workshops, which were held in March, April, and May 2004, which was produced in May 2004

- The reports on regional workshops, by province (Faritany), for the achievements in the year 2004, which were finalized in May 2005.

\section{Objectives of the annual monitoring report}

The development of the PRSP monitoring reports responds to the desire of the Government to set up a system that allows the monitoring of the achievement of the development objectives to which it subscribed. The present annual report 2005 includes the information relative to PRSP implementation for the year 2005, the analyses of achievements, results, and recommendations. These data will serve as decision making tools for the responsible officials and for the leading authorities in the country for program orientation, prioritizing actions, and improving budget allocation.

\section{Report outline}

The PRSP implementation monitoring report for the year 2005 was developed following a plan which presents first the evolution of poverty along with other poverty monitoring indicators. Thereafter, the main achievements at the national and regional level for the year 2005 under the three strategic orientations of PRSP are highlighted with regard to the reform measures and actions which were implemented in the 15 PRSP programs. In addition, analyses were conducted on the evolution of indicators, actions, and results against the objectives, the economic and financial results, and the financing of the strategy. In view of these analyses, recommendations are presented by strategic axes to remove the main constraints, to draw lessons and challenges. The last part is devoted to having an operational PRSP monitoring system. 


\section{POVERTY EVOLUTION}

The 2005 Periodic Household Survey conducted by INSTAT highlights information on household living conditions. It is representative of the whole nation and its results are significant and representative at the level of the 22 regions. Furthermore, it includes information on how households perceive their living conditions.

\subsection{POVERTY StATUS}

\subsubsection{POVERTY INCIDENCE AND INTENSITY}

In 2005, poverty incidence in Madagascar is $68,7 \%$. The phenomenon of poverty is more marked in rural than urban areas. The incidence of poverty in urban areas is $52.0 \%$ versus $73.5 \%$ in rural areas. The East coast regions of the island are the most affected by poverty. Poverty rates in these regions are close to $80 \%$. The regions of Atsimo Atsinanana and that of Vatovavy Fitovinany are the most affected with rates of $83.9 \%$ and $80.8 \%$ respectively. The region of Androy also suffers considerably from poverty with a rate of $83.3 \%$ for the region, $82.9 \%$ in urban areas and $83.4 \%$ in rural areas. Among rural regions, apart from Analamanga, the regions of Boeny and Alaotra Mangoro are the most favored ones, with poverty rates of $62.9 \%$ and $52.4 \%$ respectively.

The intensity of poverty is $26.8 \%$. Poverty is more intense in rural areas with a $28.9 \%$ intensity rate versus $19.3 \%$ in urban areas. Poor people living in rural areas are located farther from the poverty line compared with poor people living in urban areas. Overall, the intensity of poverty is deeper on the East coast, namely in Toamasina and Fianarantsoa, namely in Vatovavy Fitovinany, Ihorombe and Atsimo Atsinanana.

The severity of poverty puts greater weight on populations located farther from poverty line. Its level is $13.4 \%$ in 2005 . It is higher in rural areas at $14.5 \%$ versus $9.4 \%$ in urban areas. This confirms the fact that poor people who live in rural areas are really destitute and can hardly satisfy human basic needs.

Table 1: Spatial Poverty Profile in Madagascar in 2005 (\%)

\begin{tabular}{|c|c|c|c|c|c|c|c|c|c|}
\hline & \multicolumn{3}{|c|}{ Poverty } & \multicolumn{3}{|c|}{ Intensity } & \multicolumn{3}{|c|}{ Severity } \\
\hline & urban & rural & national & urban & rural & national & urban & rural & national \\
\hline MADAGASCAR & 52.0 & 73.5 & 68.7 & 19.3 & 28.9 & 26.8 & 9.4 & 14.5 & 13.4 \\
\hline Antananarivo & 41.6 & 64.7 & 57.7 & 13.6 & 21.9 & 19.4 & 5.8 & 9.8 & 8.6 \\
\hline Analamanga & 36.7 & 47.9 & 42.9 & 12.7 & 15.1 & 14.0 & 5.6 & 6.3 & 6.0 \\
\hline Vakinankaratra & 54.9 & 78.6 & 74.3 & 15.6 & 27.0 & 24.9 & 6.3 & 12.7 & 11.6 \\
\hline Itasy & 49.5 & 71.4 & 68.7 & 15.7 & 26.4 & 25.1 & 6.5 & 11.6 & 11.0 \\
\hline Bongolava & 53.0 & 66.8 & 64.1 & 16.8 & 21.4 & 20.5 & 7.1 & 9.1 & 8.7 \\
\hline Fianarantsoa & 71.6 & 78.7 & 77.6 & 28.8 & 30.9 & 30.6 & 14.5 & 15.1 & 15.0 \\
\hline Mahatsiatra Ambony & 67.8 & 72.9 & 72.1 & 24.9 & 25.8 & 25.6 & 11.4 & 11.5 & 11.5 \\
\hline Amoron'i Mania & 74.9 & 78.4 & 78.0 & 28.0 & 29.0 & 28.9 & 13.0 & 13.2 & 13.2 \\
\hline Vatovavy Fitovinany & 72.0 & 82.4 & 80.8 & 31.8 & 36.2 & 35.5 & 17.4 & 19.3 & 19.0 \\
\hline Ihorombe & 74.9 & 79.9 & 78.0 & 30.4 & 31.7 & 31.2 & 15.1 & 15.4 & 15.3 \\
\hline Atsimo Atsinanana & 72.9 & 85.7 & 83.9 & 32.2 & 35.8 & 35.3 & 18.1 & 18.3 & 18.3 \\
\hline Toamasina & 55.8 & 75.6 & 71.9 & 21.4 & 33.1 & 30.9 & 11.2 & 18.0 & 16.7 \\
\hline Atsinanana & 48.7 & 87.9 & 79.0 & 19.9 & 43.1 & 37.8 & 11.5 & 25.4 & 22.2 \\
\hline Analanjirofo & 71.8 & 80.3 & 79.1 & 31.4 & 36.4 & 35.7 & 16.8 & 19.7 & 19.3 \\
\hline Alaotra Mangoro & 59.6 & 57.4 & 57.7 & 18.0 & 18.7 & 18.6 & 7.1 & 8.0 & 7.8 \\
\hline Mahajanga & 47.0 & 76.6 & 70.2 & 16.1 & 28.9 & 26.2 & 7.2 & 13.9 & 12.4 \\
\hline Boeny & 24.5 & 62.9 & 48.8 & 7.4 & 19.5 & 15.1 & 3.2 & 8.4 & 6.5 \\
\hline Sofia & 65.2 & 82.2 & 80.7 & 25.5 & 33.5 & 32.8 & 12.4 & 16.8 & 16.4 \\
\hline Betsiboka & 56.3 & 75.5 & 70.0 & 18.3 & 25.4 & 23.3 & 7.7 & 10.9 & 10.0 \\
\hline Melaky & 59.4 & 65.4 & 62.7 & 20.3 & 20.7 & 20.5 & 8.8 & 8.9 & 8.8 \\
\hline Toliara & 64.3 & 77.4 & 74.8 & 28.3 & 34.0 & 32.9 & 15.9 & 19.1 & 18.4 \\
\hline Atsimo Andrefana & 61.4 & 78.4 & 75.2 & 28.8 & 37.1 & 35.5 & 16.7 & 22.1 & 21.1 \\
\hline Androy & 82.9 & 83.4 & 83.3 & 39.4 & 37.8 & 38.2 & 23.0 & 21.6 & 21.9 \\
\hline Anosy & 58.8 & 77.3 & 73.8 & 24.9 & 31.7 & 30.5 & 13.6 & 16.2 & 15.7 \\
\hline Menabe & 43.1 & 66.3 & 61.7 & 10.6 & 24.6 & 21.9 & 3.8 & 12.8 & 11.0 \\
\hline Antsiranana & 33.8 & 69.8 & 64.2 & 9.4 & 28.1 & 25.2 & 3.5 & 14.2 & 12.5 \\
\hline Diana & 21.4 & 59.2 & 49.2 & 5.2 & 19.9 & 16.0 & 1.7 & 9.3 & 7.3 \\
\hline Sava & 53.3 & 74.5 & 72.5 & 16.0 & 31.8 & 30.3 & 6.3 & 16.4 & 15.4 \\
\hline
\end{tabular}


Economic growth occurring between 2004 and 2005 benefited individuals living in both rural and urban areas. Poverty incidence decreased on the whole from $72.1 \%$ to $68.7 \%$ between 2004 and 2005 . The impact is more significant in rural than urban areas. Indeed, the decrease in the poverty incidence is only 1.7 points in urban areas versus 3.8 points in rural areas. This may be explained by the fact that the impacts on individuals living in urban areas were limited by increases in prices which were more significant in urban than in rural areas. On the other hand, incomes among urban people who are generally wage earners were more rigid to increases compared to those of rural people who benefited from the increase in the prices of food items.

The intensity of poverty decreased slightly in Madagascar from $31.6 \%$ to $26.8 \%$ between 2004 and 2005. In urban areas, it remained stable but it decreased slightly in rural areas. It declined slightly in almost all areas except in urban Toliara where it moved from $23.6 \%$ to $28.6 \%$. This decrease in intensity assumes a decline in inequality in the distribution of consumption during the year 2005.

Table 2: Evolution of Poverty Indicators

\begin{tabular}{|c|c|c|c|c|c|c|c|c|c|}
\hline & \multirow[b]{2}{*}{ Year } & \multicolumn{4}{|c|}{ P0 Poverty rate } & \multicolumn{4}{|c|}{ P1 Intensity of poverty } \\
\hline & & 2001 & 2002 & 2004 & 2005 & 2001 & 2002 & 2004 & 2005 \\
\hline \multirow[t]{3}{*}{ Antananarivo } & The whole & 48,3 & 66,0 & 59,8 & 57,7 & & & & 19,4 \\
\hline & Urban & 28,3 & 51,2 & 39,2 & 41,6 & 21,1 & 23,1 & 16,0 & 13,6 \\
\hline & Rural & 57,1 & 72,3 & 68,2 & 64,7 & 25,6 & 38,1 & 26,6 & 21,9 \\
\hline \multirow[t]{3}{*}{ Fianarantsoa } & The whole & 83,2 & 91,0 & 86,0 & 77,6 & & & & 30,6 \\
\hline & Urban & 59,8 & 78,5 & 78,4 & 71,6 & 25,5 & 42,4 & 34,4 & 28,8 \\
\hline & Rural & 87,9 & 93,5 & 87,5 & 78,7 & 49,5 & 60,7 & 41,5 & 30,9 \\
\hline \multirow[t]{3}{*}{ Toamasina } & The whole & 82,3 & 86,3 & 77,1 & 71,9 & & & & 30,9 \\
\hline & Urban & 60,8 & 66,9 & 63,7 & 55,8 & 28,5 & 33,2 & 25,3 & 21,4 \\
\hline & Rural & 87,9 & 91,9 & 80,8 & 75,6 & 48,3 & 57,1 & 43,2 & 33,1 \\
\hline \multirow[t]{3}{*}{ Mahajanga } & The whole & 72,4 & 89,1 & 74,1 & 70,2 & & & & 26,2 \\
\hline & Urban & 50,7 & 71,0 & 54,3 & 47,0 & 17,4 & 33,6 & 21,3 & 16,1 \\
\hline & Rural & 78,4 & 93,8 & 79,0 & 76,6 & 40,0 & 63,8 & 36,6 & 28,9 \\
\hline \multirow[t]{3}{*}{ Toliara } & The whole & 76,1 & 81,2 & 72,3 & 74,8 & & & & 32,9 \\
\hline & Urban & 53,3 & 58,3 & 60,5 & 64,3 & 25,5 & 25,1 & 23,6 & 28,3 \\
\hline & Rural & 83,3 & 87,5 & 75,5 & 77,4 & 43,6 & 53,5 & 31,2 & 34,0 \\
\hline \multirow[t]{3}{*}{ Antsiranana } & The whole & 69,2 & 83,7 & 65,4 & 64,2 & & & & 25,2 \\
\hline & Urban & 30,1 & 62,5 & 36,7 & 33,8 & 8,7 & 28,1 & 12,6 & 9,4 \\
\hline & Rural & 79,0 & 88,6 & 71,7 & 69,8 & 34,1 & 56,7 & 30,5 & 28,1 \\
\hline \multirow[t]{3}{*}{ Madagascar } & The whole & 69,6 & 80,7 & 72,1 & 68,7 & & & 31,6 & 26,8 \\
\hline & Urban & 43,9 & 61,6 & 53,7 & 52,0 & 18,1 & 29,3 & 20,2 & 28,9 \\
\hline & Rural & 77,2 & 86,4 & 77,3 & 73,5 & 39,8 & 53,0 & 34,8 & 19,3 \\
\hline
\end{tabular}

Source: INSTAT/DSM/EPM2005

\subsubsection{POVERTY INDICATORS ACCORDING TO HOUSEHOLD CHARACTERISTICS}

The poverty ratio increases with household size. Large size households always make up the most vulnerable ones. While poverty incidence is $50.22 \%$ for smaller size households ( 2 to 4 people), it is $88.2 \%$ for households with 8 to 10 people. Similarly, poverty intensity and severity are also high in large sized households.

Table 3: Poverty Indicators as per Household Size

\begin{tabular}{|c|c|c|c|c|c|c|c|c|c|}
\hline & P0 & & & P1 & & & $\mathrm{P} 2$ & & \\
\hline & urban & rural & The whole & urban & rural & The whole & urban & rural & The whole \\
\hline Singleton & 10.15 & 18.18 & 15.96 & 3.03 & 5.49 & 4.81 & 1.3 & 2.27 & 2 \\
\hline 2 to 4 & 36.42 & 54.75 & 50.22 & 11.76 & 17.71 & 16.24 & 5.25 & 7.88 & 7.23 \\
\hline 5 to 7 & 54.32 & 76.27 & 71.19 & 19.21 & 28.87 & 26.64 & 9.08 & 13.94 & 12.82 \\
\hline 8 to 10 & 75.57 & 90.66 & 88.18 & 33.89 & 41.28 & 40.07 & 18.2 & 22.49 & 21.78 \\
\hline More than 11 & 83.25 & 91.92 & 90.56 & 38.16 & 44.25 & 43.29 & 20.29 & 25.57 & 24.74 \\
\hline Total & 51.96 & 73.48 & 68.75 & 19.34 & 28.89 & 26.79 & 9.43 & 14.5 & 13.39 \\
\hline
\end{tabular}

Source: INSTAT/DSM/EPM2005 
Small scale farm operators are always among the most vulnerable groups with a poverty ratio of $78.3 \%$ and a poverty intensity of $31.4 \%$. Unskilled workers and labor, namely those living in rural areas are considerably affected by poverty. Executives as a whole are the least vulnerable ones.

The poverty ratio among independent workers is $56.0 \%$. The difference between rural and urban people is fairly obvious for this group: while the incidence is $46.6 \%$ in urban areas, it is $64.7 \%$ in rural areas. This may be linked to the nature of activities that independent workers conduct in each area. In urban areas, most independent workers are traders whereas, in rural areas, basketry and handicraft activities are the most widespread ones.

Table 4: Poverty Indicator as per Socioeconomic Groups

\begin{tabular}{|c|c|c|c|c|c|c|c|c|c|}
\hline & $\mathrm{PO}$ & & & $\mathrm{P} 1$ & & & $\mathrm{P} 2$ & & \\
\hline & urban & rural & national & Urban & rural & national & urban & rural & national \\
\hline Senior executive & 7.3 & 65.2 & 24.1 & 2.0 & 11.5 & 4.8 & 0.8 & 2.6 & 1.3 \\
\hline Middle executive or supervisor & 20.8 & 47.0 & 32.7 & 6.5 & 13.3 & 9.5 & 2.6 & 5.4 & 3.9 \\
\hline Skilled worker or wage earner & 30.8 & 48.0 & 38.5 & 10.0 & 15.9 & 12.6 & 4.3 & 6.7 & 5.4 \\
\hline Unskilled worker & 52.6 & 72.5 & 63.2 & 17.3 & 28.6 & 23.3 & 7.7 & 14.1 & 11.1 \\
\hline Laborer & 75.0 & 75.9 & 75.6 & 31.5 & 29.1 & 29.9 & 15.7 & 14.5 & 14.9 \\
\hline Remunerated trainee & 32.9 & 82.1 & 51.8 & 5.6 & 35.2 & 17.0 & 1.1 & 17.0 & 7.2 \\
\hline Independent & 46.6 & 64.7 & 56.0 & 15.6 & 24.8 & 20.4 & 7.3 & 12.6 & 10.1 \\
\hline Unemployed & 32.7 & 78.4 & 52.1 & 10.7 & 32.1 & 19.8 & 4.7 & 16.5 & 9.7 \\
\hline Non working & 45.2 & 70.1 & 56.4 & 17.0 & 33.8 & 24.5 & 8.2 & 19.7 & 13.4 \\
\hline Smallholder & 73.0 & 78.8 & 78.3 & 30.2 & 31.6 & 31.4 & 15.7 & 16.0 & 16.0 \\
\hline Medium holder & 70.7 & 72.4 & 72.2 & 28.0 & 28.5 & 28.4 & 14.5 & 14.2 & 14.3 \\
\hline Large holder & 61.3 & 59.8 & 60.0 & 20.2 & 19.5 & 19.6 & 8.5 & 8.4 & 8.4 \\
\hline Fishermen & 18.1 & 12.0 & 13.5 & 6.1 & 2.6 & 3.4 & 2.8 & 1.0 & 1.4 \\
\hline Other & 71.2 & 85.9 & 78.0 & 25.9 & 19.8 & 23.1 & 12.5 & 8.1 & 10.5 \\
\hline Total & 52.0 & 73.5 & 68.8 & 19.3 & 28.9 & 26.8 & 9.4 & 14.5 & 13.4 \\
\hline
\end{tabular}

Source: INSTAT/DSM/EPM2005

Overall, woman headed households are less likely to be poor than male headed ones. The poverty ratio among woman headed households is $67.5 \%$ versus $69.0 \%$ among male headed households. This situation is not apparent because, in reality, woman headed households are the most vulnerable ones. Indeed, women heads of households are generally living separately or divorced and are more sensitive to various economic and social shocks. Thus, when women who live alone are removed from this group, the poverty rate among women is higher than the rate observed among men, with poverty incidence of $73.3 \%$ and $70.6 \%$ respectively. The difference is more marked in urban than rural areas.

Table 5: Poverty Indicators as per household head gender

\begin{tabular}{|c|c|c|c|c|c|c|c|c|c|}
\hline & \multicolumn{3}{|l|}{$\mathrm{PO}$} & \multicolumn{3}{|l|}{$\mathrm{P} 1$} & \multicolumn{3}{|l|}{$\mathrm{P} 2$} \\
\hline \multicolumn{10}{|c|}{ All households } \\
\hline $\mathrm{CM}$ & urban & Rural & national & urban & rural & national & urban & rural & national \\
\hline Male & 51.2 & 73.8 & 69.0 & 18.8 & 29.1 & 26.9 & 9.1 & 14.6 & 13.4 \\
\hline Female & 56.0 & 71.4 & 67.5 & 22.2 & 27.5 & 26.2 & 11.3 & 13.8 & 13.2 \\
\hline Both & 52.0 & 73.5 & 68.8 & 19.3 & 28.9 & 26.8 & 9.4 & 14.5 & 13.4 \\
\hline \multicolumn{10}{|c|}{ Households with more than 2 people } \\
\hline male & 52.6 & 75.5 & 70.6 & 19.4 & 29.9 & 27.6 & 9.4 & 15.0 & 13.8 \\
\hline Female & 61.5 & 77.2 & 73.3 & 24.7 & 30.5 & 29.0 & 12.6 & 15.5 & 14.8 \\
\hline The whole & 53.9 & 75.7 & 71.0 & 20.2 & 30.0 & 27.8 & 9.9 & 15.1 & 13.9 \\
\hline
\end{tabular}

Source: INSTAT/DSM/EPM2005

\subsection{OPINIONS EXPRESSED BY HOUSEHOLDS ABOUT THEIR LIVING CONDITIONS}

\subsubsection{DePENDING ON THE LOCATION OF THE RESIDENCE}

In $2005,47.7 \%$ population declared they were in difficulty versus $0.3 \%$ who responded that they live easily. While, in rural areas, half of the individuals were classified in difficulty, the rate decreases 
according to the size of the location of residence and is $22 \%$ in the capital. The existence and availability of infrastructure and provision of services are probably the causes of this.

Table 6: Household Opinions on their own standard of living as per residence location

Unit: \%

\begin{tabular}{llllll}
\hline & $\begin{array}{l}\text { Live } \\
\text { comfortably }\end{array}$ & Live moderately & $\begin{array}{l}\text { Have to be } \\
\text { careful }\end{array}$ & In difficulty & Total \\
\hline Capital city & 0.5 & 42.0 & 35.5 & 22.0 & 100.0 \\
Large Urban Center & 1.8 & 28.2 & 31.1 & 38.9 & 100.0 \\
Secondary Urban Center & 0.5 & 22.2 & 33.5 & 43.9 & 100.0 \\
Rural & 0.2 & 16.2 & 33.0 & 50.6 & 100.0 \\
\hline National & 0.3 & 18.9 & 33.1 & 47.7 & 100.0 \\
\hline
\end{tabular}

Source: INSTAT/DSM/EPM2005

Depending on the regions, the proportion of those who think they live easily or averagely is significantly higher in the regions of Ihorombe, Analamanga, Bongolava and Atsimo Andrefana with rates that are higher than $25 \%$. These two categories include only $10 \%$ of those who live in the regions of Atsimo Atsinanana and Menabe.

Table 7: Household Opinions on their own standard of living as per regions

Unit: \%

\begin{tabular}{|c|c|c|c|c|c|}
\hline & $\begin{array}{l}\text { Live } \\
\text { comfortably }\end{array}$ & $\begin{array}{l}\text { Live } \\
\text { moderately }\end{array}$ & $\begin{array}{l}\text { Have to be } \\
\text { careful }\end{array}$ & In difficulty & Total \\
\hline Analamanga & 0.5 & 29.4 & 38.2 & 31.9 & 100.0 \\
\hline Vakinankaratra & 0.2 & 13.4 & 50.2 & 36.2 & 100.0 \\
\hline Itasy & NS & 23.1 & 30.4 & 46.5 & 100.0 \\
\hline Bongolava & 0.8 & 27.3 & 9.2 & 62.8 & 100.0 \\
\hline Mahatsiatra Ambony & 0.2 & 18.6 & 30.3 & 50.9 & 100.0 \\
\hline Amoron'I Mania & NS & 10.6 & 28.5 & 60.9 & 100.0 \\
\hline Vatovavy Fitovinany & 0.1 & 17.5 & 39.2 & 43.2 & 100.0 \\
\hline Ihorombe & 1.4 & 34.2 & 16.2 & 48.3 & 100.0 \\
\hline Atsimo Atsinanana & NS & 5.7 & 27.7 & 66.6 & 100.0 \\
\hline Atsinanana & 0.7 & 16.0 & 34.3 & 49.0 & 100.0 \\
\hline Analanjirofo & 0.6 & 17.2 & 23.5 & 58.8 & 100.0 \\
\hline Alaotra Mangoro & 0.1 & 19.4 & 32.6 & 47.9 & 100.0 \\
\hline Boeny & 0.1 & 19.0 & 23.0 & 57.9 & 100.0 \\
\hline Sofia & 0.4 & 15.4 & 28.0 & 56.3 & 100.0 \\
\hline Betsiboka & 0.2 & 17.4 & 22.8 & 59.7 & 100.0 \\
\hline Melaky & 0.3 & 14.9 & 48.3 & 36.5 & 100.0 \\
\hline Atsimo Andrefana & 0.3 & 26.8 & 27.8 & 45.2 & 100.0 \\
\hline Androy & 0.1 & 14.1 & 20.1 & 65.7 & 100.0 \\
\hline Anosy & 0.1 & 16.7 & 37.0 & 46.2 & 100.0 \\
\hline Menabe & 0.1 & 7.7 & 37.2 & 55.0 & 100.0 \\
\hline Diana & 0.7 & 17.7 & 46.9 & 34.7 & 100.0 \\
\hline Sava & 0.7 & 15.2 & 32.8 & 51.3 & 100.0 \\
\hline National & 0.3 & 18.9 & 33.1 & 47.7 & 100.0 \\
\hline
\end{tabular}

Source: INSTAT/DSM/EPM2005 


\subsubsection{SUBJECTIVE CLASSIFICATION IN QUINTILE OF STANDARD OF LIVING}

Overall, Malagasy households think they are part of the middle or poor classes. $36 \%$ households declared they are part of third quintile ( $20 \%$ middle households), $40 \%$ classified themselves in the $20 \%$ moderately poor, $21 \%$ consider themselves among the poorest $20 \%$. In general, no significant change is observed across regions, except in the region of Menabe and that of Sofia where many households feel they are in the poorest category: $34 \%$ in Menabe and $38 \%$ in Sofia.

Table 8: Subjective Classification into living standard quintile as per region

Unit: \%

\begin{tabular}{|c|c|c|c|c|c|c|}
\hline REGION & $\begin{array}{l}\text { Very } \\
\text { wealthy }\end{array}$ & $\begin{array}{l}\text { Moderately } \\
\text { wealthy }\end{array}$ & Average & Moderately poor & Very poor & Total \\
\hline ANALAMANGA & 0.0 & 4.2 & 46.7 & 37.0 & 12.1 & 100.0 \\
\hline VAKINANKARATRA & 0.0 & 1.6 & 41.7 & 41.7 & 15.0 & 100.0 \\
\hline ITASY & 0.0 & 6.9 & 44.9 & 22.9 & 25.3 & 100.0 \\
\hline $\begin{array}{l}\text { BONGOLAVA } \\
\text { MAHATSIATRA }\end{array}$ & 0.0 & 4.6 & 34.9 & 26.2 & 34.3 & 100.0 \\
\hline AMBONY & 0.0 & 2.5 & 41.4 & 35.8 & 20.3 & 100.0 \\
\hline $\begin{array}{l}\text { AMORON'I MANIA } \\
\text { VATOVAVY }\end{array}$ & 0.0 & 1.9 & 26.2 & 52.1 & 19.8 & 100.0 \\
\hline FITOVINANY & 0.0 & 4.2 & 33.3 & 49.2 & 13.2 & 100.0 \\
\hline $\begin{array}{l}\text { IHOROMBE } \\
\text { ATSIMO }\end{array}$ & 0.0 & 5.7 & 45.5 & 29.1 & 19.7 & 100.0 \\
\hline ATSINANANA & 0.4 & 1.7 & 13.6 & 55.4 & 29.0 & 100.0 \\
\hline ATSINANANA & 0.2 & 2.1 & 31.7 & 44.7 & 21.4 & 100.0 \\
\hline ANALANJIROFO & 0.0 & 1.4 & 33.1 & 34.9 & 30.6 & 100.0 \\
\hline ALAOTRA MANGORO & 0.3 & 2.9 & 30.8 & 42.3 & 23.8 & 100.0 \\
\hline BOENY & 0.5 & 1.6 & 30.9 & 43.7 & 23.4 & 100.0 \\
\hline SOFIA & 0.0 & 3.2 & 26.8 & 32.2 & 37.8 & 100.0 \\
\hline BETSIBOKA & 0.0 & 1.9 & 28.7 & 48.6 & 20.7 & 100.0 \\
\hline MELAKY & 0.0 & 3.4 & 37.1 & 44.6 & 14.9 & 100.0 \\
\hline ATSIMO ANDREFANA & 0.0 & 5.4 & 37.2 & 40.0 & 17.4 & 100.0 \\
\hline ANDROY & 0.1 & 5.6 & 21.0 & 58.5 & 14.9 & 100.0 \\
\hline ANOSY & 0.0 & 1.9 & 42.7 & 40.6 & 14.8 & 100.0 \\
\hline MENABE & 0.0 & 1.3 & 14.7 & 49.8 & 34.3 & 100.0 \\
\hline DIANA & 0.1 & 1.8 & 38.9 & 41.6 & 17.7 & 100.0 \\
\hline SAVA & 0.0 & 3.7 & 36.7 & 31.0 & 28.6 & 100.0 \\
\hline National & 0.1 & 3.2 & 35.6 & 40.4 & 20.7 & 100.0 \\
\hline
\end{tabular}

Source: INSTAT/DSM/EPM2005

\subsubsection{Financial Situation of the Households}

Most Malagasy households are vulnerable. $22 \%$ households are obliged to be indebted to satisfy their needs and $30 \%$ drew from their savings. $34 \%$ declare that their income is barely sufficient to satisfy their needs. Thus, $86 \%$ Malagasy households are fighting to survive.

The analysis per region indicates that the situation is relatively more difficult in the regions of Sofia, Atsimo Atsinanana and Amoron'i Mania. In these regions, more than nine households out of ten declare that their financial situation is very delicate and that they do not manage to save money. Households in Menabe and Atsimo Atsinanana are the most affected by indebtedness (close to $45 \%$ each). It is rarely possible to save money (less than $15 \%$ households). 
Table 9: Financial Situation as per region

\begin{tabular}{|c|c|c|c|c|c|c|}
\hline \multirow{2}{*}{ REGION } & \multirow{2}{*}{$\begin{array}{l}\text { Secure } \\
\text { much } \\
\text { saving }\end{array}$} & & \multicolumn{3}{|c|}{ Unit: \% } \\
\hline & & $\begin{array}{l}\text { Secure a } \\
\text { little saving }\end{array}$ & $\begin{array}{l}\text { Incomes only } \\
\text { sufficient for } \\
\text { covering } \\
\text { expenses }\end{array}$ & $\begin{array}{l}\text { Have to draw } \\
\text { from their } \\
\text { savings }\end{array}$ & $\begin{array}{l}\text { Have to be } \\
\text { indebted } t\end{array}$ & Total \\
\hline ANALAMANGA & 2.7 & 19.1 & 40.3 & 28.0 & 9.9 & 100 \\
\hline VAKINANKARATRA & 2.0 & 12.0 & 50.5 & 22.2 & 13.3 & 100 \\
\hline ITASY & 2.1 & 9.9 & 44.7 & 22.5 & 20.9 & 100 \\
\hline BONGOLAVA & 1.9 & 12.5 & 36.3 & 24.3 & 25.0 & 100 \\
\hline $\begin{array}{l}\text { MAHATSIATRA } \\
\text { AMBONY }\end{array}$ & 2.7 & 7.3 & 33.8 & 31.0 & 25.1 & 100 \\
\hline AMORON'I MANIA & 0.5 & 6.5 & 19.3 & 33.4 & 40.3 & 100 \\
\hline $\begin{array}{l}\text { VATOVAVY } \\
\text { FITOVINANY }\end{array}$ & 1.7 & 16.6 & 38.9 & 24.5 & 18.3 & 100 \\
\hline IHOROMBE & 5.6 & 13.5 & 45.4 & 21.7 & 13.9 & 100 \\
\hline ATSIMO ATSINANANA & 0.7 & 4.0 & 11.8 & 38.5 & 45.0 & 100 \\
\hline ATSINANANA & 1.5 & 13.4 & 37.3 & 23.2 & 24.5 & 100 \\
\hline ANALANJIROFO & 1.1 & 9.6 & 31.0 & 29.7 & 28.6 & 100 \\
\hline ALAOTRA MANGORO & 4.2 & 12.9 & 32.5 & 25.9 & 24.5 & 100 \\
\hline BOENY & 5.2 & 14.4 & 32.8 & 23.3 & 24.3 & 100 \\
\hline SOFIA & 0.9 & 6.4 & 17.8 & 35.8 & 39.2 & 100 \\
\hline BETSIBOKA & 2.2 & 11.8 & 27.5 & 42.3 & 16.3 & 100 \\
\hline MELAKY & 1.9 & 13.1 & 26.0 & 46.5 & 12.6 & 100 \\
\hline ATSIMO ANDREFANA & 1.0 & 18.6 & 38.3 & 33.9 & 8.3 & 100 \\
\hline ANDROY & 1.6 & 8.5 & 15.6 & 60.2 & 14.1 & 100 \\
\hline ANOSY & 0.8 & 14.6 & 28.6 & 44.7 & 11.3 & 100 \\
\hline MENABE & 1.6 & 21.3 & 23.6 & 9.6 & 44.0 & 100 \\
\hline DIANA & 4.0 & 14.9 & 21.1 & 33.9 & 26.1 & 100 \\
\hline SAVA & 1.8 & 11.8 & 37.8 & 23.8 & 24.9 & 100 \\
\hline National & 2.1 & 12.9 & 33.9 & 29.5 & 21.6 & 100 \\
\hline
\end{tabular}

Source: INSTAT/DSM/EPM2005

\subsubsection{EVOLUTION OF THE STANDARD OF LIVING FOR THE LAST YEAR}

Malagasy people have very clear viewpoints concerning the standard of living of individual households in the course of the last year: the situation has deteriorated. More than $41 \%$ households affirmed this. On the other hand, more than $40 \%$ mentioned a status quo. Less than $18 \%$ felt an improvement in the standard of living in their household.

The households in the regions of Sofia and those in Vakinankaratra saw an improvement in their standard of living. Respectively $26 \%$ and $25 \%$ of them affirmed this during the survey. On the other hand, the situation has deteriorated in the region of Sava and that of Atsimo Atsinanana with more than $54 \%$ of the households as a whole confirming this.

Opinions are strongly linked to current living conditions. Rich people felt richer and richer whereas, according to poor people, their situation is increasingly worsening. While only one third of the households in the richest quintile mentioned deterioration in their standard of living, the related proportion reaches $52 \%$ among those who are in the poorest quintile. 
Table 10: Living Standard Evolution in the course of last year

\begin{tabular}{|c|c|c|c|c|c|}
\hline & & & & & Unit: \% \\
\hline REGION & Improved & Stable & Deteriorated & NPP & Total \\
\hline ANALAMANGA & 13.2 & 46.9 & 39.8 & 0.0 & 100 \\
\hline VAKINANKARATRA & 24.7 & 33.8 & 41.5 & 0.0 & 100 \\
\hline ITASY & 22.7 & 53.2 & 24.1 & 0.1 & 100 \\
\hline BONGOLAVA & 21.3 & 40.2 & 38.2 & 0.3 & 100 \\
\hline MAHATSIATRA AMBONY & 23.0 & 37.3 & 39.7 & 0.0 & 100 \\
\hline AMORON'I MANIA & 12.8 & 35.4 & 51.8 & 0.0 & 100 \\
\hline VATOVAVY FITOVINANY & 15.4 & 40.1 & 43.0 & 1.4 & 100 \\
\hline IHOROMBE & 17.9 & 46.3 & 35.7 & 0.2 & 100 \\
\hline ATSIMO ATSINANANA & 9.7 & 34.9 & 55.0 & 0.4 & 100 \\
\hline ATSINANANA & 13.6 & 53.0 & 33.4 & 0.0 & 100 \\
\hline ANALANJIROFO & 13.1 & 38.9 & 47.7 & 0.3 & 100 \\
\hline ALAOTRA MANGORO & 18.6 & 40.0 & 41.4 & 0.0 & 100 \\
\hline BOENY & 12.4 & 40.5 & 46.5 & 0.6 & 100 \\
\hline SOFIA & 26.5 & 41.6 & 31.7 & 0.3 & 100 \\
\hline BETSIBOKA & 19.2 & 35.9 & 44.6 & 0.4 & 100 \\
\hline MELAKY & 9.5 & 46.2 & 43.8 & 0.5 & 100 \\
\hline ATSIMO ANDREFANA & 19.8 & 38.6 & 41.6 & 0.1 & 100 \\
\hline ANDROY & 20.0 & 47.2 & 32.3 & 0.5 & 100 \\
\hline ANOSY & 18.4 & 37.6 & 44.0 & 0.0 & 100 \\
\hline MENABE & 6.7 & 40.1 & 52.9 & 0.3 & 100 \\
\hline DIANA & 15.6 & 31.7 & 52.7 & 0.0 & 100 \\
\hline SAVA & 10.4 & 27.2 & 62.3 & 0.0 & 100 \\
\hline National & 17.2 & 40.8 & 41.8 & 0.2 & 100 \\
\hline
\end{tabular}

Source: INSTAT/DSM/EPM2005

If one regards in more detail, expenditure items, access to education and health care are the ones in which households recorded much improvement in the last year. Indeed, 17\% household recorded improvement regarding access to education and $20 \%$ of them affirmed the same regarding access to health care. For the other expense items such as food consumption, living place, and clothing, the proportion does not exceed $10 \%$.

The situation is not the same in the various regions of Madagascar. Access to education improved in the region of Vakinankaratra and that of Sava, contrary to what is felt by the quasi totality of households in the region of Menabe and those in Atsimo Atsinanana. As for health, the improvement is very much felt in the region of Vakinankaratra and Matsiatra Ambony.

In addition to the criteria linked to the poverty line, the perception of Malagasy households is that they are not satisfied with their life in general. More than half of them feel unhappy in their life and only $6 \%$ answered that they are happy. However, in the region of Sava, this proportion is more than $13 \%$ or households as a whole.

Compared with the situation in 2001 (before the presidential election), the satisfaction level among households has declined. Almost $55 \%$ of the population noticed that. This decline is felt more in the regions of Sofia, Menabe and Atsimo Atsinanana. More than $70 \%$ households in these regions made the same observation.

\subsubsection{The Opinion of Households Regarding the Future of the Country}

For the households as a whole, $35.4 \%$ were "optimistic" in 2005 ; versus $18.4 \%$ who were "pessimistic" and $20.5 \%$ of the total number of households deemed that there will be no change. In 2004, these proportions were $52.9 \%, 25.4 \%$ and $14.3 \%$ respectively. The "optimism rate" has therefore recorded a slight fall as regards the future of the country. 
The percentage of households who affirmed being optimistic regarding the future of the country is increasing with the quintile of consumption. It moved from $25.5 \%(38.6 \%)$ in the poorest quintile to $42.2 \%(54.4 \%)$ to the richest quintile.

Table 11: Household distribution as per opinion on the country's future, per "quintile"

Unit: \%

\begin{tabular}{l|llllll}
\hline & Poorest ones & $2^{\text {nd }}$ Quintile & $3^{\text {rd }}$ Quintile & $4^{\text {th }}$ Quintile & Richest ones & National \\
\hline Optimistic & 25.5 & 31.1 & 34.5 & 38.2 & 42.2 & 35.4 \\
No change & 21.7 & 21.6 & 20.5 & 19.7 & 19.6 & 20.5 \\
Pessimistic & 17.2 & 18.3 & 19.0 & 18.4 & 18.7 & 18.4 \\
Don't know & 32.1 & 25.7 & 23.6 & 22.1 & 17.5 & 23.3 \\
Don't express their view & 3.5 & 3.4 & 2.4 & 1.5 & 2.0 & 2.4 \\
\hline Total & 100.0 & 100.0 & 100.0 & 100.0 & 100.0 & 100.0 \\
\hline Source: INSTAT/DSM/EPM2005 & & & & & &
\end{tabular}

Analyzing according to the region of residence of the household, the region of Bongolava is the one where the greatest number of households are "optimistic" with a proportion of $47.9 \%$, and in the region of Vakinankaratra the proportion is $47.1 \%$. The maximum "pessimism" rate was, however, recorded in the region of Melaky with a proportion of $35.7 \%$.

Table 12: Household Distribution as per opinion on the country's future, per region

Unit: \%

\begin{tabular}{|c|c|c|c|c|c|c|}
\hline & Optimistic & No change & Pessimistic & Don't know & Don't express their view & Total \\
\hline Analamanga & 44.4 & 24.5 & 19.7 & 10.9 & 0.4 & 100.0 \\
\hline Vakinankaratra & 47.1 & 13.6 & 18.5 & 20.0 & 0.8 & 100.0 \\
\hline Itasy & 44.4 & 8.4 & 7.9 & 38.6 & 0.8 & 100.0 \\
\hline Bongolava & 47.9 & 13.4 & 18.6 & 18.2 & 1.9 & 100.0 \\
\hline Matsiatra Ambony & 34.8 & 16.1 & 23.7 & 23.5 & 1.8 & 100.0 \\
\hline Amoron'i Mania & 41.2 & 20.3 & 25.1 & 13.1 & 0.4 & 100.0 \\
\hline Vatovavy Fitovinany & 23.5 & 18.3 & 14.2 & 39.9 & 4.2 & 100.0 \\
\hline Ihorombe & 26.0 & 20.3 & 12.8 & 37.2 & 3.8 & 100.0 \\
\hline Atsimo Atsinanana & 5.8 & 25.1 & 15.3 & 44.2 & 9.5 & 100.0 \\
\hline Atsinanana & 44.7 & 26.0 & 8.5 & 19.5 & 1.3 & 100.0 \\
\hline Analanjirofo & 44.4 & 14.0 & 7.1 & 27.7 & 6.8 & 100.0 \\
\hline Alaotra Mangoro & 42.6 & 15.1 & 17.2 & 22.8 & 2.3 & 100.0 \\
\hline Boeny & 29.2 & 26.0 & 11.6 & 27.8 & 5.4 & 100.0 \\
\hline Sofia & 20.1 & 29.4 & 27.6 & 21.5 & 1.4 & 100.0 \\
\hline Betsiboka & 46.6 & 18.7 & 21.7 & 13.0 & NS & 100.0 \\
\hline Melaky & 13.6 & 30.6 & 35.7 & 13.2 & 6.9 & 100.0 \\
\hline Atsimo Andrefana & 26.5 & 32.9 & 26.4 & 12.6 & 1.7 & 100.0 \\
\hline Androy & 30.4 & 14.3 & 14.6 & 39.3 & 1.4 & 100.0 \\
\hline Anosy & 39.6 & 19.7 & 20.3 & 16.9 & 3.5 & 100.0 \\
\hline Menabe & 43.7 & 22.5 & 11.0 & 22.1 & 0.7 & 100.0 \\
\hline Diana & 20.8 & 34.0 & 23.8 & 20.1 & 1.3 & 100.0 \\
\hline Sava & 13.4 & 8.1 & 23.2 & 46.0 & 9.3 & 100.0 \\
\hline National & 35.4 & 20.5 & 18.4 & 23.3 & 2.4 & 100.0 \\
\hline
\end{tabular}

Source: INSTAT/DSM/EPM2005

The proportion of household optimistic increases with the level of education moving from $23.7 \%$ of the population in non educated households to $48.4 \%$ in the population of households having a "tertiary" education level. This trend was especially observed in 2004. 
Table 13: Household Distribution as by the opinion on the country's future, as by the education level of family head

Unit: \%

\begin{tabular}{l|lllll}
\hline & Uneducated & Primary education & Secondary education & Tertiary education & National \\
\hline Optimistic & 23.7 & 37.1 & 44.3 & 48.4 & 35.4 \\
No change & 24.0 & 19.7 & 18.3 & 18.3 & 20.5 \\
Pessimistic & 18.9 & 17.7 & 19.5 & 21.8 & 18.4 \\
Don't know & 30.5 & 23.1 & 16.2 & 10.0 & 23.3 \\
Don't express their view & 3.0 & 2.5 & 1.9 & 1.5 & 100.0 \\
\hline Total & 100.0 & 100.0 & 100.0 & 100.0 \\
\hline
\end{tabular}

Source: INSTAT/DSM/EPM2005

\subsection{EVOLUTION OF MAIN INDICATORS FOR MONITORING OF POVERTY}

Table 14: The 31 indicators for PRSP Monitoring

\begin{tabular}{|c|c|c|c|c|c|c|c|}
\hline & & 2001 & 2002 & 2003 & 2004 & 2005 & source \\
\hline & Poverty and social indicators & & & & & & \\
\hline 1 & Poverty rate (in \% of poor population/population) & 69.6 & 80.7 & 73.6 & 72.1 & 68.9 & INSTAT \\
\hline 2 & $\begin{array}{l}\text { Number of telephone connections (fixed and cellular) for } 1,000 \\
\text { inhabitants }\end{array}$ & 20 & 21.0 & 22.6 & 23.3 & 25.4 & MTPC \\
\hline 3 & Under five child mortality (out of 1,000 children aged under 5 ) & 130.0 & 128.0 & & 94.0 & & INSTAT \\
\hline 4 & AIDS prevalence among pregnant women & & & 1.1 & 1.1 & & CNLS \\
\hline 5 & $\begin{array}{l}\text { Net enrolment rate (school numbers of children aged } 6 \text { to } \\
\text { 10/population of school age)public and private }\end{array}$ & 64.9 & 70.0 & 82.0 & 97 & 98.0 & MENRS \\
\hline 6 & DTC3 Immunization rate (under 1 year old infants) in \% & & 61.5 & 73.3 & 75.1 & 87 & MSPF \\
\hline 7 & Primary school completion rate in \% & 35.0 & 35.0 & 39.5 & 47.0 & 60 & MENRS \\
\hline 8 & Literacy rate ( $\%$ of $15+$ year old people who can read and write) & 57 & 57.2 & 57.0 & 57.0 & 56.1 & INSTAT \\
\hline 9 & Medical prescription achievement rate in CSBs (in \%) & & 84.3 & 90.7 & 85.5 & 74.6 & MSPF \\
\hline \multirow[t]{2}{*}{10} & $\begin{array}{l}\text { Percentage of people who have sustainable access to a drinking } \\
\text { water source }\end{array}$ & & 29.5 & 29.4 & 29.4 & 31.3 & INSTAT \\
\hline & Infrastructure indicators & & & & & & \\
\hline 11 & Maintained and /or rehabilitated roads - in $\mathrm{Km}$ & 485 & 485 & 1850 & 8627 & 8982 & MTPT \\
\hline 12 & Isolation rate & & & 59.0 & 40.0 & 33.0 & MTPT \\
\hline 13 & Transportation fees reduction Percentage & & & 12.4 & -18.0 & 8.4 & MTPT \\
\hline 14 & Number of inhabitants per operational CSB 1 and CSB 2 & 5645 & 5700 & 6705 & 6853 & 6807 & MSPF \\
\hline 15 & Number of children (6-10) of school age for an operational EPP & 126.4 & 145.0 & 146.0 & 140.0 & 148.0 & MENRS \\
\hline 16 & Number of latrines & 49 & 51 & 50 & 50 & 51 & INSTAT \\
\hline \multirow[t]{2}{*}{17} & Number of electrified villages & & & 128 & 81 & 45 & MEM \\
\hline & Good governance indicators & & & & & & \\
\hline 18 & Time required for creating an enterprise & & & 3 days & 3 days & 3 days & MICDSP \\
\hline 19 & Revenue as a percentage of GDP & 9.7 & 7.7 & 10.0 & 11.2 & 10.5 & DGE \\
\hline 20 & Budget deficit (in \% of GDP) & -4.0 & -5.7 & -4.9 & -5.7 & -4.1 & DGE \\
\hline 21 & Number of inhabitants per policeman & & & 2450 & & 2055 & SESP \\
\hline 21 & Number of Inhabitants per "gendarme" & & & 1562 & 1591 & 1000 & MINDEF \\
\hline 22 & Number of prosecuted corruption cases & & & 0.0 & 12 & 6 & MIN JUSTICE \\
\hline \multirow[t]{2}{*}{23} & Number of backlogged cases (\%) & $26.4 \%$ & $22.8 \%$ & $10.0 \%$ & $16.0 \%$ & $14.0 \%$ & JUSTICE \\
\hline & Primary sector indicators & & & & & & \\
\hline 24 & $\begin{array}{l}\text { Agricultural production index (basic index }=100 \text { in } 2003 . \\
p=2,800.000 \text { tons of rice) }\end{array}$ & & & 100 & 111 & 124 & MAEP \\
\hline 25 & Reforested area (basic index $=100$ in $2002 . s=1,568$ ha) & 91.6 & 100.0 & 397.4 & 466.4 & & MEEF \\
\hline 26 & Value of investment in the mining sector (in US\$ millions) & & & & 354 & 542 & MEM \\
\hline
\end{tabular}


2005 PRSP Progress Report

\begin{tabular}{|r|l|r|r|r|r|r|r|}
\hline & \multicolumn{1}{|c|}{$\mathbf{2 0 0 1}$} & $\mathbf{2 0 0 2}$ & $\mathbf{2 0 0 3}$ & \multicolumn{1}{c|}{$\mathbf{2 0 0 4}$} & $\mathbf{2 0 0 5}$ & source \\
\hline & Macroeconomic indicators & & & & & & \\
\hline 27 & Total education budget (basic index 100= 2002) & 76.4 & 100.0 & 97.9 & 135.4 & 169.9 & MENRS \\
\hline $\begin{array}{r}27 \\
\text { bis }\end{array}$ & $\begin{array}{l}\text { Budget share allocated to MENRES compared with the overall } \\
\text { budget (in \%) }\end{array}$ & & & 20.13 & 23.41 & 21.28 & MENRS \\
\hline 28 & Total health budget (basic index = 100 = 2002) & 93.4 & 100.0 & 110.8 & 117.5 & MSPF \\
\hline $\begin{array}{r}28 \\
\text { bis }\end{array}$ & $\begin{array}{l}\text { budget share allocated to MSPF compared with the overall } \\
\text { budget (in \%) }\end{array}$ & & & 9.0 & 8.34 & 7.89 & MSPF \\
\hline 29 & GDP (growth rate in \%) & 6.7 & -12.7 & 9.8 & 5.3 & 4.6 & INSTAT \\
\hline 30 & Inflation rate (average CPI over period, annual variation) in \% & 7.4 & 16.5 & -1.7 & 13.8 & 11.4 & INSTAT \\
\hline 31 & Export (basic index 100 = 2002) & 113.9 & 100.0 & 163.1 & 182.7 & 198.0 & INSTAT \\
\hline
\end{tabular}

Table 15: Social Sector specific Indicators (see errata on page 85)

The following indicators, specific to health and education sectors will be monitored in the same way as the first 31 indicators

\begin{tabular}{|c|c|c|c|c|c|c|c|c|}
\hline Subprogram & Interim indicators & $\begin{array}{c}\text { Achievement } \\
2003 \\
\end{array}$ & $\begin{array}{c}2004 \\
\text { Objective }\end{array}$ & $\begin{array}{c}\text { Achievement } \\
2004 \\
\end{array}$ & $\begin{array}{c}2005 \\
\text { Objective }\end{array}$ & $\begin{array}{c}\text { Achievement } \\
2005 \\
\end{array}$ & $\begin{array}{c}2006 \\
\text { Objective }\end{array}$ & $\begin{array}{c}2007 \\
\text { Objective } \\
\end{array}$ \\
\hline \multirow{10}{*}{$\begin{array}{l}\text { Fundamental } \\
\text { education }\end{array}$} & $\begin{array}{l}\% \text { of } 6 \text { year old enrolled children } \\
\text { in the first cycle of fundamental } \\
\text { education }\end{array}$ & 80.0 & 81.0 & 94.0 & 94.0 & 94.0 & 94.0 & 94.0 \\
\hline & $\begin{array}{l}\text { MENRES budget share } \\
\text { allocated to EPPs (in \%) }\end{array}$ & 53.0 & 58.0 & 54.3 & 60.0 & 64.0 & 67.0 & 66.0 \\
\hline & \multirow{2}{*}{$\begin{array}{l}\text { MENRES budget execution } \\
\text { Non salary recurrent } \\
\text { Capital expenditures }\end{array}$} & 97.4 & 95.0 & 93.15 & 93.0 & & 95.0 & 95.0 \\
\hline & & 93.7 & 95.0 & 84.8 & 90.0 & & 92.0 & 92.0 \\
\hline & \multirow{3}{*}{$\begin{array}{l}\text { Repetition percentage: public + } \\
\text { private in \% } \\
\text { Public + private in \%. urban } \\
\text { Public + private in \%. rural }\end{array}$} & 29.0 & 22.0 & 29.9 & 19.0 & 18.2 & 15.0 & 12.0 \\
\hline & & 20.0 & 19.0 & 17.5 & 11.0 & & 8.0 & 6.0 \\
\hline & & 32.0 & 29.0 & 31.4 & 27.0 & & 15.0 & 12.0 \\
\hline & \multirow{3}{*}{$\begin{array}{l}\text { Pupil/ teacher ratio in all public } \\
\text { primary schools } \\
\text { The whole } \\
\text { urban } \\
\text { rural }\end{array}$} & 59 & 57 & 56 & 56 & 60.0 & 54 & 53 \\
\hline & & 46 & 46 & & 49 & & 48 & 46 \\
\hline & & 60 & 58 & & 56 & & 54 & 53 \\
\hline \multirow{11}{*}{ Health } & $\begin{array}{l}\text { Drug availability rate in CSBs in } \\
\% \\
\text { Chloroquine or equivalent }\end{array}$ & 89.9 & 95.0 & 96.0 & 90.0 & 56.0 & 90.0 & 90.0 \\
\hline & \multirow{4}{*}{\begin{tabular}{|l|} 
FAF or equivalent \\
Cotrimoxazole or equivalent \\
Paracetamol or equivalent \\
Vitamin A or equivalent
\end{tabular}} & 83.7 & 95.0 & 84.5 & 85.0 & 38.1 & 85.0 & 85.0 \\
\hline & & 83.0 & 95.0 & 94.7 & 90.0 & 56.1 & 90.0 & 90.0 \\
\hline & & 79.4 & 95.0 & 90.6 & 90.0 & 55.2 & 90.0 & 90.0 \\
\hline & & 93.4 & 95.0 & 93.5 & 90.0 & 65.0 & 90.0 & 90.0 \\
\hline & $\begin{array}{l}\text { MSPF budget share allocated to } \\
\text { SSDs (in \%) }\end{array}$ & 53.65 & 44.0 & 54.07 & 44.20 & 54.20 & 55.0 & 56.0 \\
\hline & \multirow{2}{*}{$\begin{array}{l}\text { MSPF Budget execution: } \\
\text { Non salary recurrent } \\
\text { Capital expenditures }\end{array}$} & 95.0 & 70.7 & 83.7 & 85.0 & & 87.0 & 90.0 \\
\hline & & 99.4 & 86.2 & 86.2 & 90.0 & 57.8 & 95.0 & 95.0 \\
\hline & \multirow{2}{*}{$\begin{array}{l}\text { Delivery rate with professional } \\
\text { assistance in all: } \\
\text { Public CSB and CHD 1, in \% } \\
\text { Public CHD 2, in \% }\end{array}$} & 28.04 & 35.0 & 26.10 & 27.10 & 19.7 & 28.5 & 29.9 \\
\hline & & 2.08 & 2.1 & 2.2 & 2.1 & & 2.15 & 2.2 \\
\hline & $\begin{array}{l}\text { Medical cure consultation rate in } \\
\text { public CSBs, new case/ year }\end{array}$ & 0.57 & 0.4 & 0.49 & 0.58 & 0,45 & 0.61 & 0.64 \\
\hline
\end{tabular}

In $2005,68.9 \%$ of the population classified as poor versus $72.1 \%$ in 2004 and $80.7 \%$ in 2002 . The level in 2002 was mainly due to the political, economic and social crises. In 2004 and 2005, inflation in urban areas had especially negative impacts among non executive wage earners. The increase in basic commodity prices, which was due to an unfavorable international context, reduced the purchasing power of wage earners. Nevertheless, inflation also translated into increases in producer prices. This contributed to encouraging production in suburban and rural areas. There was also an improvement in infrastructure and access to localities, but these were mitigated by the increases in fuel prices. Finally, the actions undertaken by the state in primary enrolment (free of charge) and in health (for vulnerable households) had positive impacts on household living conditions.

The forecast for child and infant mortality ratio at $88 \%$ is explained by improved prevention against diseases, the improved availability of health services and household living conditions in general. 
In 2005 , the literacy rate among individuals aged 15 years old and more is $62.9 \%$ versus $59.2 \%$ in 2004. It increased consistently: $50 \%$ in $1999,53 \%$ in 2001 and $57 \%$ in 2002 . This is the fruit of the efforts undertaken in the area of education in the past years.

$39,6 \%$ of Malagasy population has access to protected water in 2005. Compared with the figures in the previous years, a continuous improvement of the situation is recorded: $24.7 \%$ in 2001 and $29.4 \%$ in 2002 and $32.2 \%$ in 2004 . This change is more significant in urban than rural areas. In large urban centers, the rate of access to drinking water was more than $95 \%$ in 2004 , whereas it was only $70 \%$ in 2001. Conversely, the rate in rural areas varies only from $12.7 \%$ to $31.2 \%$ during the same period.

In 2005 , close to $51.5 \%$ of the population have a toilet. The difference is very significant between urban and rural areas. The rate achieved was more than $84 \%$ in large urban centers, whereas it is $47 \%$ in rural areas. The situation has improved since 2001.

In 2002, the GDP growth rate was negative $-12.7 \%$. This is explained by the crisis that affected the country. In 2003, the growth rate reached $9.8 \%$. This corresponds to resumption of economic activity. Following a return to normalcy in the economic situation of the country, the GDP evolution followed a sustained pace in 2004 and 2005 with growth rates respectively in the order of $5.3 \%$ and $4.9 \%$. The slowdown observed in 2005 results from the increasing price of oil on the world market and from the harmful effects of power cuts on the activities of enterprises.

The $18.4 \%$ inflation rate of the average CPI between 2004 and 2005 is explained by: - the large price increase during the second half of 2004, the CPI levels at the beginning of 2005 indicates a $12.8 \%$ difference compared to the 2004 average. The year-on-year change (December 2004 to December 2005 ) is $11.4 \%$. The determinants of this evolution include the repetitive increases in fuel prices on the international market and the upward revisions to the energy tariff. Nevertheless the price of rice also increased moderately during the lean period at the end of 2005.

The volume of exports has increased continuously since 2002 (base 100): 163.1 in 2003, 182.7 in 2004 and 198.0 in 2005. This situation results from several factors: amongst others, the decline in vanilla global prices in 2005 which entails the increase in volume export of the product, the diversification of exports from Madagascar with the emergence of new products such as essential oils, industrial stones, etc., and the depreciation of the national currency. 


\section{ECONOMIC AND FINANCIAL ANALYSIS}

\subsection{ECONOMIC AND FINANCIAL RESULTS}

The effect of globalization is the inevitable impact of the international context on domestic economic and financial evolution. What characterizes the 2005 international context is the fluctuation of the price of petroleum products, followed by deterioration of the terms of trade for developing countries importing petrol. This tendency continued during the first few months of the year 2006.

Amongst others, the deceleration of global economic growth, despite the rapid expansion in China and India, is worth mentioning in that respect, as well as the appreciation of the US dollar against all strong currencies, in particular the Euro.

At the national level, the increase in the prices of petroleum products had harmful effects on enterprise activities, and the phenomenon was worsened by power outage. Nevertheless, the tourism activities are pursuing their trajectory of growth. The depreciation of the Ariary against the dollar was more significant, but this was relaxed against the Euro. The cancellation of a part of the debt to the IMF, which is an initiative of the G8, and the disbursement by the European Union of their budget support, improved the profile of the public finances. Compared to the year 2004, the deficit of the Global Operations of the Treasury, as a percentage of GDP decreased.

The government stuck to the continuation of a macro-economic policy aimed at restoring the domestic and external equilibrium and, in this context, it had put a stress on the good management of public finances and the regulation of the monetary policy according to the evolution of the internal and external economic situation.

In 2005 , the strategy of the fight against poverty was supported by various international financial assistance covering twelve (12) specific fields.

In general, these projects observed satisfactory commitment rates estimated on average at $110.5 \%$ of the volume of open credit in 2005.

Table 16: External financing of the investments: Situation of the commitments in 2005 (in Ariary)

\begin{tabular}{|l|r|r|c|}
\hline & Open Credit & Commitments & Rate \\
\hline Capital subsidies & 338860000000 & 438519612000 & $129,4 \%$ \\
\hline Loan funds & 363260000000 & 346126440000 & $95,3 \%$ \\
\hline Other public loans & 8000000000 & 14948000 & $0,2 \%$ \\
\hline \multicolumn{1}{|c|}{ Total } & 710120000000 & 784661000000 & $110,5 \%$ \\
\hline
\end{tabular}

\subsubsection{ECONOMIC GROWTH AND PRICES}

In 2005 , the economic growth rate was $4.6 \%$ versus an initial forecast of $7.0 \%$. This adjustment downward is an expression of the harmful effects of the fuel price increases on the economy. Moreover, the power outages and the dismantling of the multi-fiber agreement had a negative impact on the activities of the industrial sector and those of the export processing zones in particular.

Thus the branches of activities of the secondary sector increased on average only by $3.0 \%$ in 2005 , compared to $6.6 \%$ in 2004 . In parallel, the contribution of the sector to GDP declined slightly, that is to say $14.6 \%$ in 2004 and $14.2 \%$ in 2005 . The performance was however good for the industrial branches of manufacturing of electrical appliances, tallow industry, textile industry, transport and construction materials.

The primary sector recorded only $2.5 \%$ growth despite the good performance in agriculture $(4.5 \%)$ which is associated with various factors such enabling climate conditions, easier access to micro finance credit and to fertilizers, the development of communication infrastructures. On the other hand, livestock and fishery production stagnated.

The tertiary sector contributed to an important part in GDP formation. Though this sector recorded less rapid development than in 2004 in construction and repair work, with a 6.1\% growth rate, it benefited from expansion in increased primary and secondary good supply- which favored the development of some branches of the sector, in particular transportation, trade, and banking.

The BTP (Buildings and Public Works) activities slowed down following budgetary constraints which ended up with the suspension of some infrastructure work. Public investment, which was $12.5 \%$ of GDP in 2004 decreased to $10.3 \%$ in 2005 
Nevertheless, tourism recorded constant expansion due to the promotion of Madagascar as a destination. Its part in the formation of GDP is in constant increase, $2.0 \%$ in 2004 and 3.0\% in 2005.

The domestic consumption represented the equivalent of $92.3 \%$ of the GDP, of which $83.9 \%$ was for private consumption and $8.4 \%$ for public consumption. This rate evolved slightly compared with the situation in $2004(91.1 \%)$. It reflects on one hand the slow evolution of the purchases of intermediate goods and the wage bill in the public administration, and on the other hand the weak growth in volume of private consumption. So the nominal growth of private consumption, $30.2 \%$ in 2005 , was due to the rapid variation of consumer prices.

The total investments reached $22.4 \%$ of the GDP, compared with $24.3 \%$ in 2004 . The share of the private investments slightly increased $(12.2 \%$ in 2004 and $12.3 \%$ in 2005); the foreign direct investments have more than doubled, passing from 35 million SDR in 2004 to 70.3 million in 2005. During the same period the public investments have decreased because of the delay in certain work of infrastructure, $10.1 \%$ of the GDP in 2005 versus. $12.5 \%$ into 2004 .

In percentage of GDP, exports of non factor goods and services decreased, $25.6 \%$ in 2005 vs. $29.1 \%$ in 2004. This fall affected almost all the products of export, in particular those of the EPZ firms. The same tendency is observed for the imports of goods and services $(40.3 \%$ versus $43.9 \%$ for the same periods) due to the slowdown of the economic activities especially during the first semester.

Table 17: Resources and uses of the GDP in current francs (of billion Ariary)

\begin{tabular}{|c|c|c|c|c|}
\hline \multirow{2}{*}{ Headings } & \multicolumn{2}{|c|}{ Year 2004} & \multicolumn{2}{|c|}{ Year 2005} \\
\hline & Value & $\%$ & Value & $\%$ \\
\hline Primary sector & 2065,0 & 26,2 & 2603,0 & 25,8 \\
\hline Secondary sector & 1170,1 & 14,8 & 1434,0 & 14,2 \\
\hline Tertiary sector & 3909,7 & 49,6 & 5134,5 & 50,9 \\
\hline Net indirect taxes of the subsidies & 744,3 & 9,4 & 923,7 & 9,1 \\
\hline GDP at market prices & 7889,1 & 100 & 10095,2 & 100,0 \\
\hline Consumption & 7184,6 & 91,1 & 9321,1 & 92,3 \\
\hline Private & 6509,7 & 82,5 & 8474,9 & 83,9 \\
\hline Public & 674,9 & 8,6 & 846,2 & 8,4 \\
\hline Investments & 1873,4 & 23,7 & 2257,3 & 22,4 \\
\hline Private & 962,8 & 12,2 & 1238,0 & 12,4 \\
\hline Public & 910,6 & 11,5 & 1019,3 & 10,1 \\
\hline Exports of goods and services non factors & 2295,5 & 29,1 & 2588,6 & 25,6 \\
\hline Imports of goods and services non factors & 3464,5 & 43,9 & 4071,8 & 40,3 \\
\hline GDP at market prices & 7889,1 & 100,0 & 10095,2 & 100,0 \\
\hline
\end{tabular}

Following a strong $27.0 \%$ increase in consumer prices at year end in 2004 (on a year-to-year basis), inflation decreased to $11.4 \%$ (year-on-year) at end 2005 . The constitution of regulator stocks permitted the moderate evolution of the price of food items, namely the price of rice. The price of fuel, however, recorded a strong increase.

\subsubsection{Public Finance}

The stake in public finance reform is to increase tax revenues and to streamline expenditures so as to contain the deficit within tolerable limits. These reforms are articulated around the modernization of the public finance management through the application of ASYCUDA++ software at the customs service, making operational the Integrated Public Finance Management System [Système Intégré de Gestion des Finances Publiques (SIGFP)] since July 2005 in the six provinces (Faritany), and the establishment of a Medium Term Expenditure Framework (MTEF) and a program budget.

Compared to the initial objective, tax collection in the $1^{\text {st }}$ six months of 2005 recorded shortfalls due to a recession in almost all activity sectors, and the influx of exempted import goods. A trend reversal profiled in the $2^{\text {nd }}$ semester due to tax collection efforts and to intensified controls and check system. The ratio of tax revenue to GDP thus reached at $10.1 \%$ in 2005 .

Difficulties inherent to renovating the regulatory framework and principles (public procurement code, program budget) handicapped the execution of expenditures in the first months of the year 2005. But actions of training for actors at the central and ex-centric levels rapidly brought results.

On the other hand, credit was frozen for non priority sectors to remedy the weak revenue performance in the first semester.

Therefore, total expenditures reached the equivalent of $21.2 \%$ of GDP versus $25.9 \%$ in 2004 . Besides, the overall deficit on a commitment basis (including grants) was contained at $4.7 \%$ of GDP versus 5 , $1 \%$ in 2004 . 
Table 18: Financial transactions of the central Government (in billions of Ariary and in \% the GDP)

\begin{tabular}{|c|c|c|c|c|}
\hline \multirow{2}{*}{ Headings } & \multicolumn{2}{|c|}{ Year 2004} & \multicolumn{2}{|c|}{ Year 2005} \\
\hline & Value & $\%$ GDP & Value & $\%$ GDP \\
\hline Total revenue and grants & 1653.4 & 21.0 & 1682.3 & 16.7 \\
\hline Tax revenue & 887.1 & 11.2 & 1020.0 & 10.1 \\
\hline Non tax revenue & 95.2 & 1.2 & 82.8 & 0.8 \\
\hline Grants & 671.1 & 8.5 & 579.5 & 5.7 \\
\hline Currents & 311.5 & 3.9 & 81.2 & 0.8 \\
\hline Capital & 352.4 & 4.5 & 438.5 & 4.3 \\
\hline HIPC Assistance & 7.2 & 0.1 & 59.8 & 0.6 \\
\hline Total expenditure & 2045.3 & 25.9 & 2144.2 & 21.2 \\
\hline Recurrent expenses & 1027.3 & 13.0 & 1053.0 & 10.4 \\
\hline Capital expenditure & 1018.0 & 12.9 & 996.3 & 9.9 \\
\hline Internal financing & 245.4 & 3.1 & 262.8 & 2.6 \\
\hline External financing, & 772.7 & 9.8 & 733.5 & 7.3 \\
\hline Costs net of the structural reforms & -8.8 & 0.1 & -8.5 & 0.1 \\
\hline Deficit on commitment basis & -400.6 & 5.1 & -470.4 & 4.7 \\
\hline Operations of the Treasury & & & & \\
\hline of which, variation of internal arrears & -63.2 & 0.8 & 34.3 & 0.3 \\
\hline Deficit on cash basis & -463.8 & 5.9 & -436.1 & 4.3 \\
\hline Financing Gap & 0.0 & 0.0 & 0.0 & 0.0 \\
\hline GDP at market prices & 7889.1 & 100.0 & 10095.2 & 100.0 \\
\hline
\end{tabular}

\subsubsection{MONEY AND CREDIT}

Compared to the stock of end-December 2004, the broad money aggregate M3 (including narrow money or M2, and the foreign currency deposits and liabilities) declined from its rhythm of progression. This situation is the manifestation of the impact of the Central Bank interventions on the monetary market, and the structural measures that have been implemented since 2004, namely the uniformization of the reserve requirements for all deposits, the reduction of the monetary financing of the public deficit. The monetary creation resulted essentially from an increase of the commercial banks credit to the private sector and the improvement of the net external position of the banking system. Net claims of the government and the other net items of the banking system were in 2005 the factors of monetary restriction; their stocks decreased in comparison to the situation at end December 2004, the stock for the net credits to Government decreased while the stocks of the other net items of the banking system increased.

In parallel, an obviously positive evolution was recorded in the amount of public security subscription on Treasury bill market with an increasing part from the private people and the non bank institutions. In fact, it is due to the extension of the public auction of the securities in the Province of Toamasina, then of the lowering of the minimum threshold of subscription. The extension in the other Provinces is in prospect.

The outstanding claims of the banks on the economy progressed by $22.4 \%$.. The progress was more rapid in the last four months. This period coincided with the end of the tax exemption which generated cash flow needs for the financing of imports and the coverage of expenditures in local currency. Therefore, in 2005, the flows of credit to the economy were made up essentially of short term credit (Ariary 181.0 billion) that was granted to various enterprises, amongst others to fishing operating companies, industrial and commercial companies, BTP enterprises, and real estate loans to private people. The investment credits (Ariary 15.4 billion) increased, but in low proportion.

The government did a net withdrawal of 94.5 billion from the banking system, following the budget support disbursement and the increase in public securities subscribed by the non banking system. These offset partly the non-rollover of mature public securities by the by banks. Therefore, the withdrawal was more significant to commercial banks (Ariary -172.1 billion) than to the Central Bank.

Table 19: Monetary survey (of billion Ariary)

\begin{tabular}{|l|c|c|c|}
\hline \multicolumn{1}{|c|}{ Headings } & $\mathbf{2 0 0 4}$ & $\mathbf{2 0 0 5}$ & Change in \% \\
\hline ASSETS & 2213,0 & 2374,7 & 7,3 \\
Net external position & 892,9 & 968,5 & 8,5 \\
Net credits to Government & 501,4 & 404,7 & $-19,3$ \\
Credits on economy & 818,7 & 1001,5 & 22,3 \\
LIABILITIES & 2213,0 & 2374,7 & 7,3 \\
Broad Money M3 & 2111,3 & 2171,9 & 2,9 \\
Narrow Money M2 & & & \\
Money availability & 1402,6 & 1415,5 & 0,9 \\
Quasi-money liabilities & 330,8 & 392,8 & 18,7 \\
Deposits in currencies and obligations & 377,9 & 363,6 & $-3,9$ \\
Other items nets & 101,7 & 202,8 & 99,4 \\
\hline
\end{tabular}




\subsubsection{EXTERnAL TRADE}

The exports were affected by the deterioration in the terms of trade and the dismantling of the multi fiber agreement. These effects were heightened by the decline in the international demand due to slowdown of activities, especially in the main partner countries (Europe, USA, and Japan). World economic growth was $3.2 \%$ in 2005 versus $3.8 \%$ in 2004 . In this context, the value of exports indicated a net decline of $20.7 \%$ decline compared to 2004 . Nevertheless, tourism is in constant expansion with $19 \%$ increase in revenues in 2005 . Compared to the year 2004, the imports decreased in both value and volume. This decrease is consecutive to a decrease in the demand of consumption good and the removal of tax exemption from imports of capital good.

The current account balance (including official transfers) deteriorated from 10.8\% of GDP in 2004 to $11.9 \%$ in 2005 . The foreign external reserves were set to the equivalent of 2.9 months of import.

\subsubsection{MARKET AND EXChANGE RATE}

In terms of the exchange rate, the national currency recorded relative stability in 2005 following the end of considerable fluctuations that characterized the market in 2004. The national currency depreciated by $0.9 \%$ against the euro and by $15.5 \%$ against the dollar, compared to $66.3 \%$ and $53.3 \%$ respectively in 2004. In addition to the domestic inflation effect, this situation indicates the international market situation in which the US tightening of the monetary policy led by the Federal Reserve Bank favored the appreciation of the US dollar. Therefore, in this context, the euro depreciated gradually against the dollar $(15.0 \%)$. This tendency is reflected on the inter-bank foreign exchange market [Marché Interbancaire de Devises (MID)] where the depreciation of the Ariary was stronger against the dollar than the euro.

The continuous MID was established in July 2004. The objective is to have more fluid and more transparent operations. Therefore, the monthly amount of transactions increased by $22.5 \%$ in 2005,estimated at an average of Euro 116.7 million versus 95.3 million in 2004. This situation was marked by a predominant amount of currency purchases, especially purchases by banks for the financing the imports of energy, food and non food consumption goods. The Central Bank intervened as a net seller to regulate the market, in the face of the decrease in sale of foreign currency which is associated with the decrease in exports.

Table 20: Evolution of the exchange rates (in MGF)

\begin{tabular}{|l|c|c|c|c|}
\hline \multirow{2}{*}{ PERIOD } & \multicolumn{2}{|c|}{$\begin{array}{c}\text { Year 2004 } \\
\text { period average }\end{array}$} & \multicolumn{2}{c|}{$\begin{array}{c}\text { Ye05 } \\
\text { period average }\end{array}$} \\
\cline { 2 - 5 } & EURO & DOLLAR & 12115,5 & 9200,0 \\
January & 8131,3 & 6451,3 & 12281,5 & 9435,5 \\
February & 8670,5 & 6858,4 & 12570,0 & 9495,5 \\
March & 9168,8 & 7468,1 & 12537,5 & 9680,5 \\
Mayil & 10818,4 & 9022,3 & 12289,0 & 9692,0 \\
June & 12020,9 & 10015,5 & 12369,0 & 10199,5 \\
July & 13884,0 & 11437,6 & 12214,5 & 10151,0 \\
August & 13260,7 & 10801,7 & 12318,0 & 10029,5 \\
September & 12357,0 & 10199,7 & 12496,5 & 10215,5 \\
October & 12561,9 & 10318,8 & 12621,5 & 10513,5 \\
November & 12870,3 & 10330,5 & 12689,5 & 10778,5 \\
December & 12838,1 & 9868,7 & 12791,0 & 10790,5 \\
\hline Annual average & 12636,7 & 9358,9 & 12441,1 & 10015,1 \\
\hline \multicolumn{2}{|c|}{ Annual average depreciation of MGF } & 9344,3 & $-6,7 \%$ & $-6,7 \%$ \\
\hline
\end{tabular}

\subsection{Costing AND FinANCING OF the StRATEgy}

\subsubsection{Budget AlLocation fOR the IMPLEMENTATION OF THE STRATEgY}

Three (3) strategic axes characterize the poverty reduction strategy: governance, economic growth on a social broadened base, social protection, and human and material security. Each of the axes includes consistent programs concurring to achieving the specific objectives. There are, in total, fifteen (15) programs, which are:

- three (3) programs for the governance axis: governance and prevention of corruption, the respect for democracy and rule of law, local governance, 
- five (5) programs for the economic growth with a social broadened base: preservation of macroeconomic stability, the development of expanding sectors, rural development, development of the private sector and openness to international competition, and the development of infrastructure,

- six (6) programs for social protection, human and material security: improving education, vocational training and the valorization of research, fight against transmissible and non transmissible diseases, the improvement of health conditions, social protection, the valorization of cultural diversity, human and material security.

During the year 2005, the total cost for implementing the strategy, this cost is measured by the non salary expenditures as a whole (including non salary recurrent and investment from all financing sources) amounts to Ariary billion 1, 437.0 billion, of which:

- 224.7 billion for governance,

- $\quad 840.2$ billion for economic growth, and

- $\quad 372.1$ billion for social protection, human and material security.

The axis of Governance is supported by three (3) programs, i.e. the prevention of corruption for Ariary 77.4 billion (5.4\% of total), the respect of democracy and of rule of law for 110.6 billion $(7.7 \%)$, and local governance for 36.6 billion (2.5\%).

The axis called economic growth with a social broadened base includes five (5) programs, of which the preservation of macroeconomic stability for Ariary 195.0 billion (13.6\%), development of the expanding sectors for 118.5 billion (8.2\%), rural development for 94.4 billion (6.6\%), the development of infrastructure for 401.8 billion $(28.0 \%)$, and the development of the private sector, as well as the openness to international competition for 30.5 billion (2.1\%).

Social protection and human and material security include the following programs: The improvement of education, vocational training and research valorization for Ariary 220.8 billion (15.4\%), the fight against transmissible and non transmissible diseases, as well as the prevention of malnutrition, for 3.9 billion $(0.3 \%)$, the improvement of health conditions for 99.9 billion $(7.0 \%)$, social protection for 7.9 billion $(0.5 \%)$, the valorization of cultural diversity for 4.2 billion $(0.3 \%)$, and human and material security for 35.4 billion (2.5\%).

The execution of the budget in 2005 indicates technical, institutional, and operational problems, amongst others, non mastery of the new procedures relative to program budgets (ORACLE software), fairly lengthy procedures for public procurement and DTI and VAT payments, some frequent credit rearrangements, the quarterly credit was limited to $25 \%$ of recurrent credit at the outlying level in the face to the budget circular stipulating the granting of the six months credit per budget section, ....

These problems handicapped the execution of the budget, in particular during the first semester. The periodic reviews of the public expenditure permitted the identification of certain recovery measures, and their effectiveness seems to have produced positive effects: the extension of the regulatory texts on public finance, the training of ORDSEC and GAC in programming, budget execution, and public procurement (central and off center levels), the periodic monitoring of the public procurement plan, efforts undertaken by the Government to have a budget counterpart available, especially the intensification of the actions of tax and tax arrear collection, the close collaboration with the Delegates of the Expenditure Commitment Control (CDE) and the Main Treasury Officers, the inventory of needs in supplies with a view to grouping purchases, 
2005 PRSP Progress Report

Table 21: Summary of the costing s and the financing (in MGA)

\begin{tabular}{|c|c|c|c|c|c|c|c|c|}
\hline \multirow{2}{*}{$\begin{array}{l}\text { STRATEGIC } \\
\text { ORIENTATION }\end{array}$} & \multirow{2}{*}{ PROGRAM } & \multicolumn{2}{|c|}{ Cost } & \multirow{2}{*}{ TOTAL } & \multicolumn{2}{|c|}{ COMMITTED EXPENDITURES } & \multirow{2}{*}{ TOTAL } & \multirow{2}{*}{$\begin{array}{c}\text { RATE } \\
\text { (\%) }\end{array}$} \\
\hline & & RECURRENT & CAPITAL & & RECURRENT & CAPITAL & & \\
\hline \multirow{4}{*}{ GOVERNANCE } & 1. Governance and Fight against Corruption & $26,499,418,000$ & $50,931,212,000$ & $77,430,630,000$ & $22,899,182,000$ & $49,712,039,000$ & $72,611,221,000$ & 93.8 \\
\hline & $\begin{array}{l}\text { 2. Democracy and observance of the Rule of } \\
\text { Law }\end{array}$ & $26,260,354,000$ & $84,336,711,000$ & $110,597,065,000$ & $25,555,539,000$ & $80,067,948,000$ & $105,623,307,000$ & 95.5 \\
\hline & 3. Local Governance & $33,060,948,600$ & $3,561,486,000$ & $36,622,434,600$ & $32,980,834,098$ & $6,378,396,303$ & $39,359,230,401$ & 107.5 \\
\hline & PROGRAM TOTAL OF GOVERNANCE & $85,820,720,600$ & $138,829,409,000$ & $141,804,189,600$ & $79,110,714,098$ & $59,857,706,303$ & $138,968,420,401$ & 98.0 \\
\hline \multirow{6}{*}{$\begin{array}{l}\text { ECONOMIC } \\
\text { GROWTH WITH A } \\
\text { SOCIAL } \\
\text { BROADENED BASE }\end{array}$} & 4. Preservation of the macroeconomic stability & $107,341,170,000$ & $87,622,291,000$ & $194,963,461,000$ & $102,343,318,000$ & $87,981,013,000$ & $190,324,331,000$ & 97.6 \\
\hline & 5. Development of the expanding sector & $7,678,436,400$ & $110,850,468,000$ & $118,528,904,400$ & $6,702,918,619$ & $119,631,111,803$ & $126,334,030,422$ & 106.6 \\
\hline & 6. Rural development & $11,529,038,936$ & $82,882,645,800$ & $94,411,684,736$ & $10,118,380,058$ & $146,757,566,419$ & $156,875,946,477$ & 166.2 \\
\hline & 7. Private sector and Openness to competition & $14,626,150,000$ & $15,912,400,000$ & $30,538,550,000$ & $14,342,006,000$ & $23,039,703,000$ & $37,381,709,000$ & 122.4 \\
\hline & 8. Development of the infrastructure & $8,487,344,250$ & $393,301,129,500$ & $401,788,473,750$ & $6,760,771,725$ & $396,529,776,934$ & $403,290,548,659$ & 100.4 \\
\hline & TOTAL OF ECONOMIC GROWTH & $149,662,139,586$ & $690,568,934,300$ & $840,231,073,886$ & $140,267,394,402$ & $773,939,171,156$ & $914,206,565,558$ & 108.8 \\
\hline \multirow{7}{*}{$\begin{array}{l}\text { SOCIAL } \\
\text { PROTECTION, } \\
\text { HUMAN AND } \\
\text { MATERIAL } \\
\text { SECURITY }\end{array}$} & $\begin{array}{l}\text { 9. Improvement of education, vocational training } \\
\text { and valorization of research }\end{array}$ & $98,648,000,290$ & $122,195,586,800$ & $220,843,587,090$ & 0 & 0 & $159,446,791,130$ & 72.2 \\
\hline & $\begin{array}{l}\text { 10. Prevention of transmissible diseases, non } \\
\text { transmissible diseases and malnutrition }\end{array}$ & $1,034,256,330$ & $2,868,980,000$ & $3,903,236,330$ & $1,028,986,267$ & $1,905,510,866$ & $2,934,497,133$ & 75.2 \\
\hline & 11. Improvement of the health conditions & $32,294,298,633$ & $67,580,127,400$ & $99,874,426,033$ & $29,914,758,782$ & $26,643,992,291$ & $56,558,751,073$ & 56.6 \\
\hline & 12. Social Protection & $826,322,328$ & $7,071,359,800$ & $7,897,682,128$ & $805,601,328$ & $9,029,998,460$ & $9,835,599,788$ & 124.5 \\
\hline & 13. Valorization of cultural diversity & $763,253,000$ & $3,480,900,000$ & $4,244,153,000$ & $755,912,000$ & $3,169,130,000$ & $3,925,042,000$ & 92.5 \\
\hline & 15. Human and material security & $29,034,590,000$ & $6,331,385,000$ & $35,365,975,000$ & $27,579,534,000$ & $5,778,511,000$ & $33,358,045,000$ & 94.3 \\
\hline & SOCIAL PROTECTION PROGRAM TOTAL & $162,600,720,581$ & $209,528,339,000$ & $372,129,059,581$ & $60,084,792,377$ & $46,527,142,617$ & $266,058,726,124$ & 71.5 \\
\hline \multicolumn{2}{|c|}{ TOTAL OF OVERALL PROGRAM } & $398,083,580,767$ & $1,038,926,682,300$ & $1,354,164,323,067$ & $279,462,900,877$ & $880,324,020,076$ & $1,319,233,712,083$ & 97.4 \\
\hline
\end{tabular}




\subsubsection{BUDGET EXECUTION OVER THE YEAR 2005}

The commitments of the capital expenditure on foreign financing exceeded the open credit. Corresponding foreign resources and related taxes are evaluative.

The commitments of the non salary expenditure are estimated on a provisional basis at $97.3 \%$ of the planned resources for the year 2005. This performance is recorded among the various programs underlying the strategy, i.e.

- The local governance for the governance axis,

- Rural development, the expanding sector and the development of infrastructure, the development of the private sector, and the openness to international competition regarding the axis of economic growth with a social broadened base,

The programs included in the axis of human and material security overall recorded commitment rates that are relatively low, except for the social protection program.

The expenditures planned for supporting the governance axis were committed up to $96.9 \%$ of the open credit amount. The local governance program stands apart from the other programs with a commitment rate of $107.5 \%$ due to good performance in the development of the activities in the commune and the region (176.2\%), and improvement in budget and accounting management among the local governments $(99.8 \%)$. local governance benefited from UNDP support through DAP1 project, from the World Bank through the Project for Governance and Institutional Development [Projet pour la Gouvernance et le Développement Institutionnel (PGDI)], the Intervention Funds for Development [Fonds d'Intervention pour le Développement (FID)], from the European Union through the project of Support to Rural Communes and Organizations for the Development of the South (ACORDS), and from USAID. FID and ACORDS were performing in 2005, recording satisfactory disbursement rates.

The commitment rate is relatively less high for the other programs, i.e. $96,9 \%$ for the prevention of corruption and 95, 5\% for the observance of the Rule of Law and Democracy. The prevention of corruption benefited from the World Bank support through PGDI project for setting up an Independent Anticorruption Office [Bureau Indépendant Anticorruption (BIANCO)], and UNDP through DAP 1 project, of which objective is to have an operational and efficient Higher Council Corruption Prevention [Conseil Supérieur de Lutte Contre la Corruption (CSLCC)]. The PGDI disbursements were relatively low in 2005.

The axis economic growth with a social broadened base for which resources were committed up to $108.8 \%$ of the open credit amount, benefited from the strong contribution of the quasi-totality of the programs supporting the strategy. This is valid for the following:

- The development of expanding sectors,

- Rural development,

- The development of the private sector and

- The development of infrastructure.

Overall, the activities underlying the same programs recorded satisfactory commitment rates except for those relating to the improvement of animal production, the management and coordination of economic programs, the strengthening of the meteorological waking system, and the civil engineering sector.

Therefore, the commitment rate achieved was $107.1 \%$ for the activity of the donors partnership for a good management of fishing resources, $93.1 \%$ for governance in the agricultural sector, $288.2 \%$ for the promotion of the diversification and transformation of agricultural products, $169.8 \%$ for the improvement of rural productivity, $91.2 \%$ for the access to land tenure, $94.0 \%$ for opening up and practicability of national roads, $123.6 \%$ for the sanitation and development of human establishments, and $291.2 \%$ for the improvement of the productivity and efficiency of the transportation system.

The program development of the expanding sectors was supported, amongst others, by the project for the development of the expanding sectors [Projet pour le Développement des Secteurs Porteurs (PDSP)], the project for the governance of mineral resources [Projet pour la Gouvernance des Ressources Minérales (PGRM)], the Environmental Program III (PE III), and the project Energy II. Performance in terms of disbursements was satisfactory for the project Energy II compared to the other projects that finance the program.

The projects that supported the program of the development of infrastructure recorded satisfactory disbursement rates in overall. They are the maintenance program of national road (PNER) and that of engineering works (PNEOA) of the European Union, AfDB project on cyclone damages, the World Bank Sectoral Transportation (PST) and Urban Infrastructure, the projects financed by Japan, USAID and the French Development Agency (AFD). 
The axis social protection, human and material security was less performing with a commitment rate provisionally estimated at $71.5 \%$ of the open credit amount in 2005 . Contribution was stronger for the following programs:

- social protection,

- human and material security,

- valorize the cultural diversity.

It declined for the fight against the transmissible and non transmissible disease $(75.2 \%)$, the improvement of health conditions $(56.6 \%)$, the improvement of education, vocational training and the valorization of research $(72.2 \%)$.

The same axis was supported, amongst others, by CRESED II and FID, OPEP on increase in the enrolment rate, the development of capacity (construction and rehabilitation of EPP and CEG), the alleviation of charges on pupils' parents, CRESAN II and the USAID project for the training of medical agents, the allocation of medical equipment, the construction and the rehabilitation of health infrastructure, the distribution of vitamin A for children under five, the sale of contraceptives and condoms.

\subsubsection{CONCLUSION}

The year 2006 is marked by the establishment of the consistency between the budget and the poverty reduction objectives. The expenditure commitments, which were of course satisfactory in 2005 , will be strengthened by the continued implementation of what has been achieved so far, especially the rapid establishment of credit for the year 2006, the ongoing actions of training for the actors in the budget process for both central and outlying levels, and larger availability of domestic resources following the intensification of tax collection check system. The budget which is the main tool for supporting the strategy will be more efficient due to the strengthening of the roles assigned to "secondary authorizing officers" and to "operations managers" (the programming of purchases depending on needs) and to breaking-in the program budget system. 


\section{THE MAIN MEASURES OF SOCIAL AND ECONOMIC REFORMS}

The year 2005 is especially marked by the continuation and the intensification of reform actions engaged during the previous years under the PRSP. The relevant achievements as regards reforms which are recorded at the levels of the three PRSP strategic axes during the 2005 fiscal year are as follows:

\subsection{AXIS 1: GOVERNANCE}

Governance and the observance of democracy

- Reorganizing and improving the functioning of the National Election Council (CNE)

Governance and the rule of Law

- Restructuring the former Immigration and Emigration Service and rationalizing the file processing circuit at the Directorate of Immigration and Emigration

- Restructuring the Armed Forces: The draft texts relating to restructuring the Armed Forces were finalized and sent to the President's Office for comments

Local Governance

- Redefining the missions and the duties of the Ministry of Decentralization and Land Management (MDAT);

- Developing the National Decentralization / Deconcentration Policy

- Preparing the effective implementation of the Local Development Funds (FDL)

Improving the coordination of reform actions in the Administration

- Setting up the Reform Program for Public Service Efficiency [Program de Réformes pour l'Efficacite de l'Administration (PREA)] that will be provided with the Council of Advisory and Monitoring [Conseil d'Orientation et de Suivi (COS)], and with a general coordination body that will deal with the design, coordination, management and facilitation of the actions as a whole to reform, modernize the Administration, and to use new technologies.

\subsection{AXIS 2: PRODUCTION AND ECONOMY}

Public Finance Reform

- Adoption of the new framework law related to the budget law

- Effective setup of the Program Budget

- Modernization of the system for paying import duties and taxes

- Improvement of the public expenditures programming and monitoring, of the salary management in public expenditures management and execution

- Passing the decrees on the Public Procurement Regulation Authority [Autorité de Régulation des Marchés Publics (ARMP)], the Finance General Inspection (IGF), and the Disciplinary Board for Budget and Finance (CDBF)

- Developing an interaction between the customs services and the Société Générale de Surveillance (SGS), and effective use of the ASYCUDA ++ software by the customs services

- An effective Computerized System for Public Finance Management (SIGPF) and SYGADE (Foreign Debt Management System)

- Improving the transparency in budget operations including the development and the distribution of manuals of procedures relating to taxation, the information for users on tax procedure, the acquisition of control and verification materials, the acceleration of the management accounts review

- Strengthening the prevention of corruption through intensified control and verification missions within the customs and tax centers

Agriculture, livestock and fisheries

- Adopting the Land Ownership Policy Paper

- $\quad$ Updating the Sectoral Policy Paper on Livestock

- Updating the Rural Development Policy Paper

- Developing the National Rural Development Program (PNDR);

- Developing the National Strategy for the Development of the Cotton Cluster 
- Continuing the Institutional Reform of MAEP which aims to strengthen the sustainable functions of the community based Administration: DVA operations (Early Voluntary Retirement, setting up 4 new DRDRs)

- Reforming the land tenure sector: establishing the regional land tenure desks and computerizing the land tenure and topographical system

- Sustainable management of fishing resources: effective establishment of the Concerted Management Areas [Zones d'Aménagement Concerté (ZAC)]

- E-governance information system: effective setup of the intranet network at central level and the Internet connection at regional level

Environment, water and forestry

- Defining the legal and judiciary framework for the protected area system

- Ministerial decree on temporary protection of protected areas which are being established

- Update the application decree on forest legislation

- Reform the Forestry Administration: initiating the separation of the control function from the functions of designing, supporting and monitoring and evaluation

- Launching the restructuring of the Forest Sector Observatory

- Amending the text on forestry commissions following the establishment of regions

- Providing financial sustainability: make the Protected Area Foundation operational, the texts on establishing management councils and the execution units for Forest Funds

- Reinforcement of the National Reforestation Program: creating the Reforestation Parcel Reserves

- Tender system on forest harvesting: survey and procedure test on pilot sites

Tourism

- Developing the Tourism Master Plan

- Revitalizing the promotion device: making the National Tourism Office (ONT) and the Regional Tourism Offices (ORT) operational

- Revising the texts setting the rate and the distribution of the tourism tax

- standardizing tourism establishment: launching the grading of the green label, launching the classification for sustainable tourism for the establishment of accommodation and catering business;

- Restructuring the National Tourism and Hotel Business Institute [Institut National du Tourisme et de l'Hôtellerie (INTH) ], creating an ongoing training department, and creating new courses of studies

Mining

- Improve the Mining Regulation and the Law on Large Mining Investment

- Promulgate and effectively apply the texts on the Special Legislation on Mining Transactions

- Set up the Basis for Promoting Good Governance in Mineral Resources;

Industries; trade and Private Sector Development:

- Madagascar Membership to SADC

- Madagascar Membership to the Agency for Trade Insurance in Africa (Agence pour l'Assurance du Trade en Afrique )

- Develop the Investment Charter and the Ethics Code

- Develop the law on competition, law on custom clearance of rice import, and the bill on consumer protection

- Review the private status of chambers of Trade into a public status

- Develop the draft update of the application decree of the law ruling cooperatives

Transportations and roads

- Make the Port, Maritime and Fluvial Agency [Agence Portuaire, Maritime et Fluviale (APMF)] operational in June 2005

- Create the Port Company with Autonomous Management [Société Anonyme Portuaire à gestion autonome (SPAT)] at the main port of Toamasina

- Conceding the management and operation of the container terminal of the main port of Toamasina

- Adopt the regulatory texts on the institutional reform of ports, including the following: 
- $\quad$ Remolding the status of the Company Operating of the Port of Toamasina (Decree $\mathrm{n}^{\circ} 2005$ 322 on May 25, 2005)

- Give a status of an "autonomously managed national interest port" to the ports of Mahajanga, Toliara and Antsiranana/ Nosy Be and, defining the circumscription of these autonomously managed ports and authorize the creation of the autonomously managed port (decree $\mathrm{n}^{\circ} 2005-330,331,332$ on May 31, 2005)

- Inter ministerial decree setting the rate of maritime flow fees

- Ministerial decree approving the status of the company that manages autonomously the port of Toamasina (SPAT)

- Ministerial decree approving the standard convention applicable to private permissions tool with exclusive private use in Malagasy ports

- Ministerial decree approving the standard convention applied to construction permissions for the construction and use of structures, buildings and private tools in Malagasy ports

- Ministerial decree approving the convention of the public service concession, its specifications and its appendices, related to the management concession of the Container Terminal of the Port of Toamasina

- Ministerial decree authorizing the transfer of a mutual agreement of a general concession management and exploitation to the Société d'Acconage et de Manutention d'Antalaha (SAMA)

Energy

- Concede the management of the Water and electricity Company JIRAMA

- Adjust JIRAMA price rates

- Develop regulatory texts defining the fee collection mechanisms of the Electricity Regulation Office (ORE), including decree $n^{\circ}$ 2005-062 on January 25, 2005 and the Decree $n^{\circ}$ 1005-2005 on March 14, 2005

- $\quad$ Adopt 4 texts on the legal and regulatory framework of the Rural Electrifying Development Agency (ADER)

\subsection{AXIS 3: SOCIAL ASPECTS}

Education

- $\quad$ Update and validate the Education for all (EFA) Plan and approve the EFA program

- Create new study courses that fulfill the socioeconomic needs: mining and geology, agriculture and livestock, textile, gems and stoning, tourism and eco-tourism, hotel business and catering business.

- Develop working skills in work environment: develop training plans in the 22 regions Health

- Update the 2006-2008 National Health Policy

- Develop and validate the National Child Health Policy

- Improve the system of monitoring and reinforce the integration of the health system in the public structures at the decentralized level: set up the 22 Regional Directorates For Health and Family Planning (DRSPF)

- Develop the National Multisectoral Plan for fight against the avian flu

- Integrate the health component in the PDC and PDR

- Define and implement the National Family Planning Strategy

- Update the physicians' Ethics Code and the Public Health Code

- Adoption by the Parliament and approbation by the Senate of the law $n^{\circ} 031 / 2005$ on Right and on HIV, and the protection of PLHIV, and review some policy orientations that governs the actions of prevention of the HIVIAIDS, and develop and validate 5 sectoral strategic plans

- Review the National Blood Transfusion Policy

- Validate the National Prevention of Mother to Child Transmission (PMTCT) Policy

- Set up and make the National Nutrition Office (ONN) operational as the coordinating body for interventions and contributors to nutrition.

- Validate the National Technical Plan for Nutrition and finalize the National Nutrition Program 
Water and Sanitation

- Adopt the Program of Access to National Drinking Water

- Develop the Sectoral Water Policy, the National Sector Coordination Policy and the Manual of Procedures on Water and Sanitation

- Finalize the draft of the National Sanitation Strategy and Policy

Population and Social Protection

- Promulgate the law $n^{\circ}$ 2005-014 on 07/09/05 on Adoption

- Install the SIG/EPT software in all Provinces

- Develop a draft decree on small childhood supervision and care

Culture

- Promulgate the National Cultural Policy for socioeconomic development 


\section{IMPLEMENTATION OF THE FIFTEEN PRSP PROGRAMS}

\subsection{GOVERNANCE}

\subsubsection{Program 1. Governance AND ANTI- CORRUPTION PROGRAM}

\subsubsection{Subprogram: Fight against Corruption}

In keeping with the fight against corruption, three specific objectives were kept: (i) to develop and update a national anti-corruption strategy, (ii) to strengthen the anti-corruption legal framework, (iii) and to implement the national anti-corruption strategy.

\subsection{Indicators table}

Table 22: Indicators of Fight against Corruption

\begin{tabular}{|c|c|c|c|c|}
\hline \multirow{2}{*}{$\begin{array}{c}\text { Specific } \\
\text { objectives }\end{array}$} & \multirow[t]{2}{*}{ Indicators } & \multirow[t]{2}{*}{2004} & \multicolumn{2}{|r|}{2005} \\
\hline & & & Objectives & Achievements \\
\hline $\begin{array}{l}\text { Develop and } \\
\text { update a national } \\
\text { corruption } \\
\text { prevention strategy }\end{array}$ & $\begin{array}{l}\text { National } \\
\text { corruption } \\
\text { prevention } \\
\text { strategy paper } \\
\text { Survey reports }\end{array}$ & $\begin{array}{l}\text { National } \\
\text { convention } \\
\text { against corruption }\end{array}$ & $\begin{array}{l}\text { Update the } \\
\text { strategy for the } \\
\text { period from } 2005 \\
\text { to } 2007\end{array}$ & $\begin{array}{l}\text { A national strategy geared to expanding } \\
\text { economic sectors: fisheries, mining, } \\
\text { energy, water and forests, rural economy } \\
\text { (rice, vanilla, tobacco, zebus), industry and } \\
\text { handicraft, tourism }\end{array}$ \\
\hline $\begin{array}{l}\text { Strengthen the } \\
\text { legal framework of } \\
\text { the prevention of } \\
\text { corruption }\end{array}$ & $\begin{array}{l}\text { Texts } \\
\text { developed }\end{array}$ & Law on corruption & & \\
\hline $\begin{array}{l}\text { Implement the } \\
\text { National Corruption } \\
\text { Prevention } \\
\text { Strategy }\end{array}$ & $\begin{array}{l}\text { Activity reports } \\
\text { Number of } \\
\text { broadcast radio } \\
\text { and TV } \\
\text { programs }\end{array}$ & $\begin{array}{l}\text { Set up of BIANCO } \\
\text { and the Anti- } \\
\text { Corruption Penal } \\
\text { network }\end{array}$ & $\begin{array}{l}\text { Set up of } \\
\text { measuring tools } \\
\text { Extend BIANCO } \\
\text { to provinces }\end{array}$ & $\begin{array}{l}\text { The Fianarantsoa territorial branch } \\
\text { (opened in March 2006), start an annual } \\
\text { national survey (zero status) } \\
\text { Prepare a corruption observatory }\end{array}$ \\
\hline
\end{tabular}

\subsection{Result Analysis}

The anti-corruption strategy was first in 2004 oriented to public services that were permanently criticized by the public (justice, police, and land property).

In 2005, the strategy was geared towards economy, upon request by the private sector. The expanding sectors were subject to surveys and specific action programs. In addition, some integrity pillars (public or private institutions which are supposed to bear integrity values) were also subject to surveys and specific action programs (media, the Ombudsman, political parties, the civil society).

The CSLCC, the BIANCO and the Criminal Chain worked together and implemented the anticorruption strategy. Among the assessment activities, the annual national polling and the observatory must be mentioned. The first polling campaign was conducted by the American consultancy firm Casals Associated with support from a national consultancy firm. The following editions will be conducted by a national consultancy firm so as to obtain reliable results each year. The second tool to measure is the observatory which will provide information on an ongoing basis on the evolution of corruption (the forms, the behavior of players, etc.).

Both these tools aim to provide the anti-corruption bodies with accurate and up to date data to allow them to adjust the strategy and the methodological approaches.

The anti-corruption bodies noticed a lack of support from the administrations and had the impression that they were not familiar with the fight against corruption. The government should take the leadership in anti-corruption so as to create a spillover effect.

\subsubsection{Subprogram: Civil Service Reform}

The Civil service reform subprogram includes one single specific objective that is «to prepare and to carry out the civil service reform». 


\subsection{Indicators table}

Table 23: Civil Service Reform Indicators

\begin{tabular}{|c|c|c|c|c|}
\hline \multirow{2}{*}{$\begin{array}{c}\text { Specific } \\
\text { objectives }\end{array}$} & \multirow[t]{2}{*}{ Indicators } & \multirow[t]{2}{*}{2004} & \multicolumn{2}{|r|}{2005} \\
\hline & & & Objectives & Achievements \\
\hline $\begin{array}{l}\text { Prepare and } \\
\text { implement the } \\
\text { civil service } \\
\text { reform }\end{array}$ & $\begin{array}{l}\text { The reform } \\
\text { strategy and } \\
\text { plan is } \\
\text { developed } \\
\text { The manual of } \\
\text { job description is } \\
\text { available }\end{array}$ & $\begin{array}{l}\text { - } 07 \text { application decrees of the } \\
\text { general status of civil servants' } \\
\text { are adopted } \\
\text { - } 06 \text { workshops were held in } \\
\text { the capital of provinces } \\
\text { - } 22 \text { information/ training } \\
\text { workshops on civil service } \\
\text { reform strategy were held ( in } \\
\text { the } 21 \text { regions and the capital) }\end{array}$ & $\begin{array}{l}\text { Finalize the } \\
\text { development of the } \\
\text { strategy and of the } \\
\text { reform plan } \\
\text { Finalize the manual of } \\
\text { job description }\end{array}$ & $\begin{array}{l}05 \text { application decrees of the } \\
\text { general status of civil servants } \\
\text { were adopted } \\
07 \text { workshops entitled: "towards a } \\
\text { well governed, productive and } \\
\text { efficient civil service" were held } \\
\text { The VOY RINDRA operation } \\
\text { started: } \\
\text { - } 150,000 \text { questionnaires on } \\
\text { job description were distributed } \\
\quad-126,100 \text { questionnaires on } \\
\text { job description (QDP) were } \\
\text { collected } \\
\text { - } 108,429 \text { questionnaires on } \\
\text { job description captured }\end{array}$ \\
\hline
\end{tabular}

\subsubsection{Result Analysis}

The implementation decrees of the general status of civil servants, started in 2004, was pursued in 2005 and no other text has come out under the reform partly due to the budget impact that this may entail. Indeed, as the ministry in charge of Civil Service is aware of the fact that the reform initiated does not rely on a solid basis, the department in charge of the civil servant modified the process by introducing as a preliminary the Voy Rindra operation.

The main objectives of Voy Rindra are as follows:

- The classification of posts, i.e. profile-post and profile-agent adequacy;

- The harmonization of the treatment, that is the alignment of treatments in all the civil service corps;

- Establishment of a skill database.

The Voy Rindra operation will provide the basis of the reform, and the job description manual is part of the results of this an operation. It will also be possible that Voy Rindra is at the origin of the remolding of a number of texts, and this is the reason why the development of the strategy and the reform plan somehow stagnated.

The wish is that the results of the Voy Rindra operation will be published as soon as possible as this is the basis of the reform; on the other hand, any other text relative to the reform must be developed and approved thereafter. Accompanying measures such as strengthening the monitoring and the modernization body will also have to be taken so as to enhance the efficiency of the administration.

\subsubsection{AXIS 2. GOVERNANCE AND OBSERVANCE OF THE DEMOCRACY}

\subsubsection{Subprogram: Reliability of the election operations}

In order to have election operations reliable, the actions that are undertaken aim at five (5) specific objectives: (i) to improve the organization and working of the National Election Council, (ii) to reduce the contestations related to election lists, (iii) to reduce the contestations related to the election operations, (iv) to prevent corruption in election, and (v) to regularize the administrative status of citizens of vote age.

\subsection{Indicators table}

Table 24: Indicators of Reliable election operations

\begin{tabular}{|c|c|c|c|c|}
\hline \multirow[t]{2}{*}{ Specific objectives } & \multirow[t]{2}{*}{ Indicators } & \multirow[t]{2}{*}{2004} & \multicolumn{2}{|r|}{2005} \\
\hline & & & Objectives & Achievements \\
\hline $\begin{array}{l}\text { Improve the organization } \\
\text { and the functioning of the } \\
\text { National Election } \\
\text { committee (CNE) }\end{array}$ & $\begin{array}{l}\text { The Decrees adopted and } \\
\text { applied }\end{array}$ & & $\begin{array}{l}\text { Publication and } \\
\text { application of the } \\
\text { decree }\end{array}$ & $\begin{array}{l}\text { Decree } \mathrm{n}^{\circ} 2004-993 \text { on October } 26 \text {, } \\
2004 \text { defining the CNE functioning } \\
\text { mechanisms adopted }\end{array}$ \\
\hline $\begin{array}{l}\text { Regularize the } \\
\text { administrative situation of } \\
\text { the population of voting } \\
\text { age }\end{array}$ & $\begin{array}{l}\text { Number of judgments of } \\
\text { compensative birth and } \\
\text { Nation ID cards delivered }\end{array}$ & & $\begin{array}{l}\text { 112, } 101 \text { "judgments" } \\
\text { published }\end{array}$ & 30, 009 "judgments" published \\
\hline
\end{tabular}




\begin{tabular}{|l|l|l|l|l|}
\hline \multicolumn{1}{|c|}{ Specific objectives } & \multicolumn{1}{|c|}{ Indicators } & \multicolumn{1}{c|}{2004} & \multicolumn{1}{c|}{ Objectives } \\
\cline { 2 - 4 } & $\begin{array}{l}\text { Reduce contestations } \\
\text { related to election lists } \\
\text { operational } \\
\text { Number of districts having } \\
\text { reviewed their election lists } \\
\text { Computer processed } \\
\text { election lists }\end{array}$ & $\begin{array}{l}\text { Software installed and } \\
\text { election list }\end{array}$ & 107 out of 116 \\
Beeing prepared \\
$\begin{array}{l}\text { Reduce contestations } \\
\text { related to election } \\
\text { operation }\end{array}$ & $\begin{array}{l}\text { Number of stabilized } \\
\text { voting stations }\end{array}$ & $\begin{array}{l}\text { Stabilize the list and } \\
\text { the locations of voting } \\
\text { station }\end{array}$ & $\begin{array}{l}\text { Exhaustive census of Fokontany at } \\
\text { the district level }\end{array}$ \\
\hline
\end{tabular}

\subsection{Result Analysis}

Regarding the improvement of the organization and functioning of the National Election Council, the achievements for the year 2005 involve the adoption and implementation of Decree $n^{\circ} 2004-993$ of 26/10/04 organizing the CNE working mechanisms. But, despite the provision in this decree, many BLEs at District level are not operational for at least two reasons: first, the staff are temporary agents, so they are not motivated; second, not only such BLEs do not have a recurrent budget but they neither receive any instructions and/ or training from the CNE.

This situation has harmful effects, namely the delay regarding the time limit allocated to pre election actions and lack of consistency among actions by various election players.

Therefore, it is indispensable, on the one hand, to provide these BLEs with a recurrent credit and, on the other hand, to motivate the staff and provide them with training.

As regards the regularization of the administrative status of the voting age population, 30,009 birth judgments (jugements supplétifs) were provided, i.e. $30 \%$ of the objective set. This low performance is due to the fact that two similar operations were mixed up (operation of birth judgments for under age people and operation of birth judgments for adults). The objective set (112, 101 judgments provided) was distorted as it includes under age people.

The following should therefore be provided: (i) review of the materials and organizations of "birth judgments" and "CNI" operations; and (ii) use the management software for Civil Status used by the Urban Municipality of Antananarivo; and adapt it and make a general use of it in all the administrative districts and communes of Madagascar.

In keeping with reducing the contestations relating to election lists, the revision of election lists was achieved with 107 out of 116 Districts (i.e. 92\% achievement), as well as an exhaustive census of Fokontany at District level. The objective was not fully achieved due to communication problems.

Efforts will be provided to reduce the number of contestations. However, the number of newly created Fokontany should be limited to facilitate the operations related to the election.

\subsubsection{Subprogram: Citizen Participation}

The main objective in citizen participation is to support actions in information, education and communication enabling the populations to take responsibility in public life and community policy.

\subsection{Indicators table}

Table 25: Indicators of Citizen Participation

\begin{tabular}{|c|c|c|c|c|}
\hline \multirow[t]{2}{*}{ Specific objectives } & \multirow[t]{2}{*}{ Indicators } & \multirow[t]{2}{*}{2004} & \multicolumn{2}{|r|}{2005} \\
\hline & & & Objectives & Achievements \\
\hline $\begin{array}{l}\text { Support information, education and } \\
\text { communication actions in favor of the } \\
\text { taking responsibility of the population } \\
\text { in public life and the policy of the } \\
\text { community (encourage citizens' } \\
\text { accountability in public life) }\end{array}$ & \begin{tabular}{l}
\multicolumn{1}{c}{ Intermediate } \\
$\begin{array}{l}\text { Number of weekly broadcast programs } \\
\text { that are produced }\end{array}$ \\
Number of local radio speakers and \\
journalists who are trained
\end{tabular} & & $\begin{array}{l}\text { Promote the } \\
\text { participation of } \\
\text { citizens in local } \\
\text { matters }\end{array}$ & $\begin{array}{l}22 \text { broadcast programs } \\
\text { (Kaominina sy Faritra miasa) } \\
157 \text { radio speakers }\end{array}$ \\
\hline
\end{tabular}

\subsection{Result Analysis}

Achievements are recorded in the strengthening of the social dialog, the judiciary popularization for prevention and the education of the population in terms of prevention of the corruption, the distribution of civic education aids, and the training of community-based facilitators and journalists, as well as weekly programs called "Kaominina sy Faritra miasa" (= Communes and Regions which are working). To this end, achievements are recorded as follows: 22 radio programs, five training sessions for 
journalists for 157 local facilitators, and IEC sessions (Civic education aid production, distribution through 15,000 posters, 10,000 leaflets, and 5,000 brochures).

However, there was a lack of coordination between MDAT and PGDI regarding the design, the planning, and the completion of the programs.

Consequently, the challenge is to standardize internal and external communication.

\subsubsection{Program 3. Governance and legally constituated state}

5.1.3.1. Subprogram: Rationalize the Processing of administrative activities and implementation of the E-Governance

This subprogram aims at two specific objectives: (i) to reduce the malfunctioning and cumbersome practices in Administration, and (ii) To process administrative activities in a reliable, secure, and rapid manner

\subsection{Indicators table}

Table 26: Indicators of Rationalization of the processing of the Administrative Activity and the implementation of the E-governance

\begin{tabular}{|c|c|c|c|c|}
\hline \multirow[t]{2}{*}{ Specific objectives } & \multirow[t]{2}{*}{ Indicators } & \multirow[t]{2}{*}{2004} & \multicolumn{2}{|c|}{2005} \\
\hline & & & \begin{tabular}{|c|} 
Objectives \\
\end{tabular} & Achievements \\
\hline \multirow{2}{*}{$\begin{array}{l}\text { Eliminate } \\
\text { malfunctioning and } \\
\text { the complexity of the } \\
\text { administration }\end{array}$} & $\begin{array}{l}\text { Number of conducted } \\
\text { surveys }\end{array}$ & & $\begin{array}{l}\text { Conduct surveys on the processing of the } \\
\text { rationalization of administrative activity }\end{array}$ & Four (4) surveys \\
\hline & $\begin{array}{l}\text { Number of developed } \\
\text { manuals }\end{array}$ & & $\begin{array}{l}\text { Develop, edit and distribute the manuals on } \\
\text { rationalized processing of administrative } \\
\text { activities }\end{array}$ & One (1) manual of procedure \\
\hline \multirow{2}{*}{$\begin{array}{l}\text { Secure and ensure } \\
\text { the rapid processing } \\
\text { of administrative } \\
\text { activities and make } \\
\text { them reliable }\end{array}$} & Set up E -governance & & $\begin{array}{l}\text { Create the E-governance development Unit } \\
\text { (CDEG) } \\
\text { Create the National E-governance regulation } \\
\text { Agency (ANRE) }\end{array}$ & $\begin{array}{l}\text { Institution of the E-governance } \\
\text { Development Unit (CDEG) and set up } \\
\text { the National E-governance Regulation } \\
\text { Agency (ANRE) }\end{array}$ \\
\hline & & & $\begin{array}{l}\text { Set up the Information System Directorates } \\
\text { in each Ministry }\end{array}$ & $\begin{array}{l}\text { Presentation during the cabinet meeting } \\
\text { for setting up the Information System in } \\
\text { each Ministry } \\
\text { Standardize the activities of Information } \\
\text { System in each Ministry }\end{array}$ \\
\hline
\end{tabular}

\subsection{Result Analysis}

The results obtained in that area consist in the following:

- Studies of rationalizing the administrative activity processing on civil status management and the control of actions by local governments;

- Studies of rationalizing administrative activity processing on the administrative management of foreigners, for the use of the Administration, and regarding the management of the staff, for the use of the Territory Administration.

- Development of a Manual of procedures on civil status for the use of the Territory Administration agents and elected people in decentralized local governments; on the administrative management of foreigners, for the use of the Administration; regarding the management of staff, for the use of the Territory Administration; and on control of actions by local governments, for the use by the State Representatives and officials in decentralized local governments. Furthermore, training was provided to State agents in practical implementation of the manuals of procedures.

The difficulty in removing malfunctioning and cumbersome practices of the administration lies in ownership and methodology. Indeed, activities have first to be streamlines while complying with the texts in force before developing a Manual of procedures.

The most probing experience which is complying with the desired methodology and which may be generalized is the Study for rationalizing activity processing of the administrative management of foreigners, which is for the use of the Administration.

Achievements in having reliable, secure and rapid administrative activity processing involve the following:

- The coming out of the decree 2005-327 of May 25, 2005 setting the institutional framework for implementing the National Policy in E-Governance and instituting the Development Unit of EGovernance (CDEG), as well as the National Agency for Regulating and Executing E-Governance (ANRE), which are the organ in charge of establishing and developing E-Governance in Madagascar; and the adoption of the Law $\mathrm{n}^{\circ} 2005-023$ of October 17, 2005 stating the institutional reform of the Telecommunication sector. 
- The establishment of the Directorates for Information Systems in each Ministry

- The development, the validation, and the publication of the Decree $n^{\circ} 2005-591$ of September 13, 2005 establishing the Public Purchase Grouping for purchasing computer equipments and software for the Malagasy government, and of the Inter ministry decree $n^{\circ} 1207 / 2006$ dated January 26, 2006 designating the Members representing the Ministries involved in grouped computer material and software purchase relating to the government intranet, as well as of the Leader and the specification of computer materials and software that are involved.

On the other hand, normative documents were developed and finalized, namely the general texts on computer and telecommunication materials used in the government networks; the standardization of the government networks, the standardization for interconnecting the government networks, for the infrastructure of the government networks, for the IP Addressing Plan and for the Naming Plan used by the Internet of the government,

Amongst others, the training for the technical officials in Ministries in Open Office System for using and managing databases was provided. The National E-Governance Program (PNEG) was developed and the Web Sites and portal for each Ministry was completed.

The tardy validation of two texts relating to the establishment of the State E-Governance entailed the postponement of their implementation. Consequently, the establishment of the Intranet of the government at the central and regional level and of the technical infrastructure of ICT will take place only in 2006.

\subsubsection{Subprogram: Administrative Reform}

There are three specific objectives in Administrative Reform: (i) to reduce the malfunctioning in the territory Administration, (ii) to improve the functioning of Administration, and (iii) to modernize the Administration.

\subsection{Indicators table}

Table 27: Indicators for Administrative Reform

\begin{tabular}{|c|c|c|c|c|}
\hline \multirow{2}{*}{ Specific Objectives } & \multirow{2}{*}{ Indicators } & \multirow{2}{*}{2004} & \multicolumn{2}{|c|}{2005} \\
\hline & & & \begin{tabular}{|r|} 
Objectives \\
\end{tabular} & Achievements \\
\hline $\begin{array}{l}\text { Reduce } \\
\text { malfunctioning in the } \\
\text { Administration }\end{array}$ & $\begin{array}{l}\text { Reduce the time limit for obtaining } \\
\text { the stay visa from } 6 \text { to } 2 \text { months in } \\
\text { average }\end{array}$ & & $\begin{array}{l}\text { Effectiveness of the reduction of the } \\
\text { time limit for obtaining the stay visa }\end{array}$ & Objectives achieved at $92.5 \%$ \\
\hline $\begin{array}{l}\text { Improve the } \\
\text { functioning of the } \\
\text { administration }\end{array}$ & $\begin{array}{l}\text { Number of manuals published and } \\
\text { distributed } \\
\text { Number of training sessions held }\end{array}$ & & $\begin{array}{l}-5 \text { manuals } \\
\text { - training of trainers and of Heads of } \\
\text { Districts in the Regions of } \\
\text { Analamanga, Bongolava and Itasy }\end{array}$ & $\begin{array}{l}04 \text { manuals being developed } \\
03 \text { training sessions held }\end{array}$ \\
\hline $\begin{array}{l}\text { Modernize } \\
\text { Administration }\end{array}$ & $\begin{array}{l}\text { - Number of purchased computers } \\
\text { - Number of operational computer } \\
\text { applications and functionalities } \\
\text { - Number of Directorates that are } \\
\text { connected to the Internet } \\
\text { - Website set up and accessible }\end{array}$ & & $\begin{array}{l}\text { Computerize staff management } \\
\text { Computerize materials and fiduciary } \\
\text { values management } \\
\text { Set up a new communication mode } \\
\text { within the ministry }\end{array}$ & $\begin{array}{l}\text { - } 13 \text { computers purchased } \\
-17 \text { using agents trained } \\
\text { Analysis of the current situation } \\
\text { - All directorates connected } \\
\text { - Website implemented }\end{array}$ \\
\hline
\end{tabular}

\subsection{Result Analysis}

For reducing malfunctioning in Administration, the objective of reducing the time limit for issuing stay visas from 6 to 2 months on average was achieved at $92 \%$. The procedures for issuing stay visas were facilitated by the restructuring of the former Department of Immigration and Emigration and by rationalizing the circuits for processing files at the Directorate for Immigration and Emigration.

Nevertheless, file processing still indicates delays because the management of legal document is not computerized yet.

In keeping with the improvement of the functioning of the Administration, four thematic manuals for the Administration are being developed. Training was provided in Management, Monitoring and Evaluation of projects for the executives in Territory Administration.

Conversely, the computerization of stock control and fiduciary values was not achieved due to the effects of $80 \%$ credit blockage. 
Concerning the modernization of the Administration, computerized staff management was achieved due to 13 purchased computers and training for 17 using agents. This computerization had positive effects on modernizing the monitoring of the staff management and on the effective census of active civil servants within MIRA.

Regarding the establishment of a new communication system within the Ministry, all the Directorates are connected and the MIRA website is set up. However, the latter is not operational yet pending the definite restoration and the accommodation to the server.

\subsubsection{Subprogram: Work area Environment}

The environment in the world of work includes three specific objectives, which are: (i) to strengthen the partnership among the government, workers, investors and ensure the participation of partners of social development to increase productivity; (ii) to ensure that the work market rules enable competitiveness and employment while protecting the workers' basic rights; (iii) to promote vocational training and job creation.

\subsection{Indicators table}

Table 28: Indicators for Work area Environment

\begin{tabular}{|c|c|c|c|c|}
\hline \multirow{2}{*}{ Specific objectives } & \multirow{2}{*}{ Indicators } & \multirow{2}{*}{2004} & \multicolumn{2}{|r|}{2005} \\
\hline & & & Objectives & Achievements \\
\hline $\begin{array}{l}\text { Strengthen partnership between } \\
\text { government/ investor, and ensure } \\
\text { the participation of social partners } \\
\text { in development to increase } \\
\text { productivity }\end{array}$ & $\begin{array}{l}\text { Public Private } \\
\text { Partnership } \\
\text { established }\end{array}$ & $\begin{array}{l}\text { Develop the } \\
\text { partnership with } \\
\text { the supporting } \\
\text { structures }\end{array}$ & $\begin{array}{l}\text { National } \\
\text { Employment Policy } \\
\text { implemented }\end{array}$ & $\begin{array}{l}\text { The National Employment } \\
\text { Policy (PNE) is adopted } \\
\text { The National Committee for } \\
\text { Monitoring the National } \\
\text { Employment and Poverty } \\
\text { Reduction Policy } \\
\text { (CNSPERP) is set up and } \\
\text { operational }\end{array}$ \\
\hline $\begin{array}{l}\text { Make sure that the rules of the job } \\
\text { market enable competitiveness } \\
\text { and employment while protecting } \\
\text { the fundamental rights of } \\
\text { employees }\end{array}$ & $\begin{array}{l}\text { Improved } \\
\text { judiciary } \\
\text { environment }\end{array}$ & $\begin{array}{l}\text { New Labor } \\
\text { Legislation adopted } \\
\text { (Law } n^{\circ} 2003-044 \\
\text { of July } 28,2004)\end{array}$ & $\begin{array}{l}\text { Implementation of } \\
\text { the new Labor } \\
\text { Legislation }\end{array}$ & $\begin{array}{l}3 \text { application texts for the } \\
\text { Labor Legislation adopted } \\
\text { The National Committee } \\
\text { against Child Labor is } \\
\text { operational }\end{array}$ \\
\hline $\begin{array}{l}\text { Promote vocational training and } \\
\text { job creation }\end{array}$ & $\begin{array}{l}\text { Number of new } \\
\text { jobs created per } \\
\text { year }\end{array}$ & 6,000 jobs & 7,500 jobs & 10,000 jobs \\
\hline
\end{tabular}

\subsection{Result Analysis}

The meeting of Heads of State in the African Union (AU) held in Ouagadougou (Burkina Faso) decided to give more place to employment in development policies. As a matter of fact, given the resource insufficiency in developing countries, it is imperative that they increase efficiency in their investment instead of always looking for increasing their amount. This performance may be achieved by using or exploiting in an optimal way the local resources in terms of employment and labor.

In this framework, the effort by the Government focused on two main components: strengthening Public/ Private Partnership (PPP) through the implementation of a new National Employment Policy (PNE) and the improvement of the legal environment governing the workers in the private sector by the adoption of a new work code.

As the PNE is focused much more on job creation, it will strengthen partnership with the existing support structures such as the Vocational Training Centers [Centres de Formation Professionnelle (CFP)], the Private Employment Agencies [Bureaux de Placement Privé (BPP)] and the enterprises, and will set up new structures such as the National Committee for Monitoring the National Employment Policy and Poverty Reduction [Comité National de Suivi de la Politique Nationale de I'Emploi et de Réduction de la Pauvreté (CNSPERP)]. The project called Inserting Young Unemployed People in the Active Life [Insertion des Jeunes sans emploi dans la Vie Active (IJVA)] is also enabling employment promotion. From the foregoing, the number of created employments largely exceeded the objective in 2005.

It has to be noted that, unlike PNE, the work code is somehow the general status for the private sector workers; so it only governs the existing jobs (leave, salary, medical care;..).

In the development policy, the AU recommendation in Ouagadougou focuses on an optimal use of local resources in terms of labor so that the national economy may provide an outlet to cheaper products - that is good quality and cheaper products. This policy will boost mass consumption and indirectly boost the economy. 
In this case, it is important to take into account the programming of public investment, sectors which will create many jobs such agriculture, infrastructure, and the environment. But such programming has also to study the technological option to be implemented if employment is to be preserved.

\subsubsection{Subprogram: Justice}

There are five specific objectives in justice: (i) to rehabilitate judiciary and penitentiary functions and infrastructure at national level; (ii) to reinforce the anti-corruption devices (of which to rehabilitate and organize the national committee for human rights: education component); (iii) to expedite the case processing; (iv) to enhance the legal and judiciary environment, namely in the economic area; et (v) to make imprisonment more human.

\subsection{Indicators table}

Table 29: Indicators for Justice

\begin{tabular}{|c|c|c|c|c|}
\hline \multirow{2}{*}{ Specific objectives } & \multirow{2}{*}{ Indicators } & \multirow{2}{*}{2004} & \multicolumn{2}{|c|}{2005} \\
\hline & & & Objectives & Achievements \\
\hline $\begin{array}{l}\text { Rehabilitate the judiciary } \\
\text { and penitentiary functions } \\
\text { and the infrastructures at } \\
\text { national scale }\end{array}$ & $\begin{array}{l}\text { Satisfaction rate } \\
\text { among people under } \\
\text { the jurisdiction of the } \\
\text { court (survey) }\end{array}$ & & & $40 \%$ \\
\hline $\begin{array}{l}\text { Reinforce the anti-corruption } \\
\text { devices (rehabilitate and } \\
\text { organize the National } \\
\text { Human Rights Committee: } \\
\text { education component...) }\end{array}$ & & & & \\
\hline Accelerate case processing & $\begin{array}{l}\text { Increase the rate of } \\
\text { processed cases }\end{array}$ & 7,458 verdicts published & $\begin{array}{l}\text { Clearing the } \\
\text { proceedings at the TPI } \\
\text { of Antananarivo, } \\
\text { Fianarantsoa, and } \\
\text { Antsiranana }\end{array}$ & $96 \%$ \\
\hline $\begin{array}{l}\text { Improve the legal and } \\
\text { judiciary environment in the } \\
\text { economic area }\end{array}$ & $\begin{array}{l}\text { Increased number of } \\
\text { investors }\end{array}$ & 817 & & 882 \\
\hline $\begin{array}{l}\text { Humanization of } \\
\text { imprisonment conditions }\end{array}$ & $\begin{array}{l}\text { Reducing of mortality } \\
\text { rate } \\
\text { Human Rights } \\
\text { principles applied }\end{array}$ & $\begin{array}{l}\text { Nutritional assistance to } \\
\text { prisoners with the IRCC in } 4 \\
\text { prisons (Manajary, } \\
\text { Manakara, Farafangana, } \\
\text { Moramanga) }\end{array}$ & Revitalize penal camps & $\begin{array}{l}\text { Boosting of } \\
\text { agricultural work in } \\
14 \text { penal camps and } \\
\text { harvesting of } \\
\text { products }\end{array}$ \\
\hline
\end{tabular}

\subsection{Result Analysis}

Madagascar is striving to follow the pace imposed by globalization by enhancing the business environment and by harmonizing the national laws to the international conventions or instruments. The establishment of the one stop desk GUIDE and the remolding of a number of texts are also in keeping with this effort and the Ministry of Justice plays a pre-eminent role in this process.

Within GUIDE, the ministry is represented by the Commercial Court for issuing Trade and Company [Registres de Commerce et des Sociétés (RCS)] and deed filing. Under the reform, a Committee for Business Law Reform [Comité de Réforme du Droit des Affaires (CRDA)] was established. The text relating to the trade code was renewed. Tax incentives were also set up and Madagascar is currently a member to ACA and AMGI for the purposes of securing investment.

All those measures were at the origin of the fairly high number of newly created businesses during the last two years. It has to be noted that more than three quarters of these new businesses are in the tertiary sector, namely trade, tourism and NICT. In terms of nationality, about $40 \%$ of them are French, $20 \%$ Chinese, and 10\% Mauritian.

Investors are certainly attracted by clear texts with no frequent changes, but lack of confidence among citizens towards the judiciary scheme may be an obstacle. According to a poll initiated by the CSLCC and conducted by an American University (Vanderbilt University) for the year 2005, households are not satisfied with the services provided by the judiciary system as regards transparency, accountability, corruption and performance.

To remedy this shortcoming, efforts aiming at improving access to justice by citizens were undertaken through the rehabilitation of judiciary and penitentiary functions and. Lower courts [Tribunaux de Première Instance (TPI)] were established, equipment was modernized, capacity building was provided through ongoing training, and ordinary hearings, in general and itinerant hearings in particular were multiplied.

Finally, improvement was also brought to the human aspect of imprisonment in terms of food, but also of hygiene, and health. 
To be able to take into account of the recommendations of the AU meeting in Ouagadougou in keeping with employment, tax incentives have to be developed for businesses in the labor intensive sectors.

Texts on consumer protection are also worth publishing and specialization in commercial law has to be strengthened, in particular in mediation and arbitration.

\subsubsection{Subprogram: Civil Protection}

The main objective in this area is to strengthen the protection of the population against risks and disasters.

\subsection{Indicators table}

Table 30: Indicators of Civil Protection

\begin{tabular}{|c|c|c|c|c|}
\hline \multirow{2}{*}{$\begin{array}{c}\text { Specific } \\
\text { objectives }\end{array}$} & \multirow{2}{*}{ Indicators } & \multirow{2}{*}{2004} & \multicolumn{2}{|r|}{2005} \\
\hline & & & Objectives & Achievements \\
\hline $\begin{array}{l}\text { Improve the } \\
\text { protection of } \\
\text { the } \\
\text { population } \\
\text { against risks } \\
\text { and disasters }\end{array}$ & $\begin{array}{l}\text { Decree adopted and applied } \\
\text { Number of executive staff trained } \\
\text { GRC achievement rate in training of } \\
\text { regional officials } \\
\text { Number of regions having a } \\
\text { contingency plan } \\
\text { Number of districts having erected GRC } \\
\text { Committees } \\
\text { Number of "communes" having located } \\
\text { the evacuation sites for the victims of } \\
\text { disaster }\end{array}$ & & $\begin{array}{l}\text { Publication } \\
\text { and } \\
\text { application } \\
\text { of the } \\
\text { decree }\end{array}$ & $\begin{array}{l}\text { Decree } n^{\circ} 2005-866 \text { defining the modes of } \\
\text { application of the law } n^{\circ} 2003 \text { - } 010 \text { of } \\
\text { September } 05,2003 \text { relative to the National } \\
\text { Politics of Risks Management and Disasters } \\
\text { adopted in December } 20,2005 . \\
13 \text { executives out of } 19 \\
120 \% \text { (13 regions out of } 11) \\
13 \text { regions } \\
67 \text { districts } \\
113 \text { "communes" }\end{array}$ \\
\hline
\end{tabular}

\subsection{Result Analysis}

The year 2005 was marked by several violent and devastating disasters of which the cyclones called Ernest et Felapi in the South west Region at the beginning of the year, the Inter Tropical Convergence Zone in the Regions of Anosy and the South East, the floods in the Regions of Boeny, Sofia, Diana, and Alaotra-Mangoro, the upsurge of fires in several Districts, let alone the tsunami case in Manakara and the malnutrition case in Manantenina and in Vangaindrano

Despite the existing violent and devastating disasters, the vulnerability rate among population decreased.

Due to rapid interventions, an existing evacuation plan and relief service quality, as well as agent competence and adequate equipment and materials, both human and material damages caused by such disasters were mitigated.

The actions for the year 2005 focused on setting up the structures in the National Council for Risk and Disaster Management (Conseil National de Gestion des Risques et Catastrophes), which is operational and enabled the dispatch of help and relief to disaster victims, in disasters occurring in the areas affected. Furthermore, civil protection units and standing committees for the monitoring/ evaluation of bushfires were set up in all Districts. Amongst others, training in GRC was provided to regional officials in 13 Regions out of 11 planned were achieved. Finally, emergency interventions were conducted over 83 Districts, of which 52 Districts for 69 fire cases.

Still in keeping with the strengthening of the protection of population against risks and disasters, the Decree $n^{\circ}$ 2005-866 stating the implementation mechanisms for the Law $n^{\circ} 2003-010$ of September 05, 2003 which relates to the National Policy for Risk and Disaster Management was adopted on December 20, 2005.

However, insufficient budget affected the rehabilitation work ( 01 out of 04 was achieved). The action was conditioned by the availability of the Public Investment Plan financing.

The actions to be undertaken in the year 2006 will focus on developing the CNS structure (Specific Risks) and on operationalization of the territory Structures of the National Relief Council. 


\subsubsection{Subprogram: Defense}

This subprogram includes two specific objectives: (i) to enhance the device called "DEFENSE" which is the guarantor of national sovereignty; and (ii) to strengthen the contribution of the Armed Forces to social economic development actions.

\subsection{Indicators table}

Table 31: Indicators for the Defense

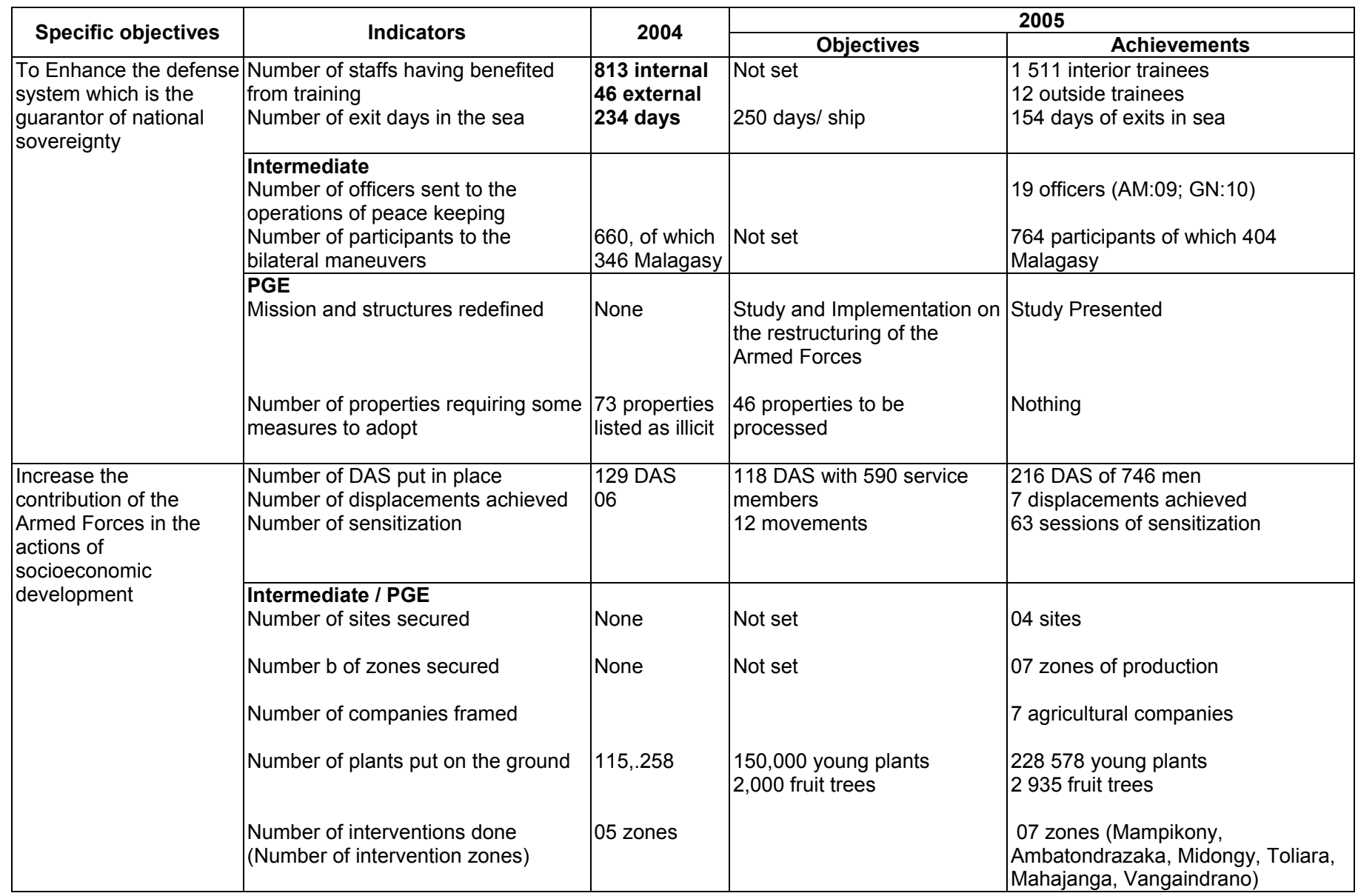

\subsection{Result Analysis}

Valorizing the defense apparatus which is the guarantor of national sovereignty, the achievements include essentially in presenting the studies for restructuring the armed forces, the standardization of refresher course regimes, the strengthening of the surveillance scheme on land, on sea and in the air, as well as the operational capacity building of the Armed Forces.

The following points are highlighted after analyzing the table:

Development in the celerity of the administrative activity of the armed forces was noticed due to standardization of refresher course regimes. The number of trainees in the course of the year increased to about $77 \%$ compared to that in 2004. Nevertheless, these training courses depend on offers by friend countries and on the credit allocated to training. The participation of 19 Malagasy Officers in inter African operations and increase in the number of Malagasy participants in bilateral drills (an increase on the order of $20 \%$ compared to the number in 2004) strengthened the operational capacity of the Armed Forces.

Despite the strengthening in the land, maritime and air surveillance device through the organization of periodical maritime and air patrols, on the one hand, and the programming of land patrols for surveillance of sensitive areas and strengthening the surveillance device of the Exclusive Economic Zone (EEZ), on the other hand, an increase is noted in illicit traffics along the coastline and excessive operating of our sea resources. This situation is due to the unavailability of the vessel called Matsilo in 2005 , which provoked a reduction of about $34 \%$ in the number of sea outgoings compared to that of 2004. 
Regarding the strengthening of the contribution by the Armed Forces to the action of social economic development, the results obtained had positive effects, namely on the vulnerability of the population, on the confidence of the population, in general and on the operators, in particular.

The analysis of the indicators in the table indicates the following:

- The trust among operators improved and the security in productive areas was strengthened due to the securing of social and productive activities by the population ( $83 \%$ increase in DAS set up compared to the objective set).

- The effect of ensuring security in the three mining sites and one natural reserve site, as well as protected areas had an impact on the decrease in deforestation, and in the number of illicit extractions and operations.

- The reduction of actions of banditry in the productive zones due to the provision of security in seven (7) production areas. Consequently, the increase in production was recorded in these zones.

- On the other hand, the farmer supervision and the rural training (agricultural tutoring) provided by 7 agricultural companies enhanced the productivity.

Awareness rising among the staff and families of service members enabled to conduct 624 blood bags sampling for an epidemiological survey. An improvement of the sport discipline among the Armed Forces was noticed. Despite the limited number of displacement undertaken ( 7 out of 12 planned were achieved), 32 medals, of which 12 gold medals, 14 silver medals, and 06 bronze medals were obtained.

In keeping with the General Policy of the government, documents relating to restructuring the Armed Forces were developed and project drafts were written out regarding the mission and duties of the Armed Forces. However, the redefined structures and missions of the Armed Forces are pending for approval.

Regarding the management of the military property assets, the processing of the registration of four (4) files were processed. Nevertheless the Files on illicit properties inventoried are still pending. This situation is due to the inexistence of credit to process the related files.

The participations of the Armed forces were effective in the prevention of deforestation on the one hand, and on the other hand in protection and the assistance to the population during the disasters through the conveyance of basic commodities to the victims in the regions.

To conclude, we can notice that the achievements of the Ministry of National Defense were tangible in terms of community based security and the contribution to the social and economic development. Therefore, it is recommended to the other Ministries to combine efforts in that direction and to assess the impacts of defense and activities of security in their respective sectors. Furthermore, taking into account of the large size of the territory, the participation of the population in areas securing is strongly desirable. Finally, the designation of a representative of the government on the sea (???) and the establishment of a new defense concept prove to be helpful.

\subsubsection{Subprogram: Public Security}

As regards public security, the specific objectives consist in ensuring the safety of people, their goods, and their activities and in enhancing the national police picture. 


\subsection{Indicators table}

Table 32: Indicators for Public Security

\begin{tabular}{|c|c|c|c|c|}
\hline \multirow{2}{*}{ Specific objectives } & \multirow{2}{*}{ Indicators } & \multirow{2}{*}{2004} & \multicolumn{2}{|l|}{2005} \\
\hline & & & Objectives & Achievements \\
\hline \multirow[t]{2}{*}{$\begin{array}{l}\text { Ensure the security of } \\
\text { people, their } \\
\text { properties and their } \\
\text { production activities }\end{array}$} & $\begin{array}{l}\text { Specific indicators } \\
\text { Proportion of secured communes } \\
\text { (PCS) } \\
\text { Evolution of Kizo guards (EGK) }\end{array}$ & $5909 \%$ & Not set & $\begin{array}{l}930 \text { communes visited } \\
\text { and secured } \\
161 \mathrm{KIZO} \text { kept }\end{array}$ \\
\hline & $\begin{array}{l}\text { Intermediate } \\
\text { Number of TPG undertaken } \\
\text { Number of cattle markets controlled } \\
\text { Number of security operations } \\
\text { conducted } \\
\text { Number of DAS set up } \\
\text { number of PA set up } \\
\text { Number of cattle thefts } \\
\text { Document on the insecurity action } \\
\text { program Established and distributed } \\
\text { Drugs and illegal alcohol seized } \\
\text { Number of watch rounds and patrols } \\
\text { Weapons and ammunitions seized } \\
\text { Number of "Dahalo" arrested } \\
\text { Nrime rate } \\
\text { Number of road infractions } \\
\text { Nevenue from road fine }\end{array}$ & $\begin{array}{l}164.033 \\
13 \\
94 \\
07 \\
65,307 \\
3.926 \\
1,015 \mathrm{Kg} \\
3,215 \mathrm{~L} \\
40,849 \\
\end{array}$ & $\begin{array}{l}\text { Not set } \\
13 \text { cattle markets } \\
98 \text { operations } \\
118 \text { DAS set up ( } 590 \text { service members) } \\
11 \text { Outposts set up } \\
\text { Improve public security } \\
\text { Drug deals reduced by } 30 \% \\
\text { Adulterated alcohol deals reduced } \\
50 \% \text { increase in watch rounds and } \\
\text { patrols } \\
\text { Road insecurity reduced } \\
25 \% \text { increase in arrests of "Dahalo" } \\
20 \% \text { reduction }\end{array}$ & $\begin{array}{l}216 \text { DAS with } 746 \text { service } \\
\text { members) } \\
68 \text { outposts } \\
54,603 \\
\text { Document on the } \\
\text { insecurity action program } \\
\text { Established } \\
2,108 \text { Kg } \\
12,291 \text { L } \\
63,070 \text { patrols } \\
\text { Weapons: } 38, \\
\text { ammunitions: } 459 \\
\text { Grenades: } 06 \\
5,249 \text { "Dahalo" arrested } \\
21 \% \text { reduction } \\
14,924 \\
\text { Increase of } 30 \% \text { of the } \\
\text { revenues in relation to } \\
2004\end{array}$ \\
\hline $\begin{array}{l}\text { Enhance the public } \\
\text { image of the National } \\
\text { Police }\end{array}$ & $\begin{array}{l}\text { Specific Indicators } \\
\text { Police force numbers per inhabitant } \\
\text { (3 policemen for } 1,000 \text { inhabitants.) } \\
\text { Coverage rate for police stations } \\
\text { Intermediate } \\
\text { Number of newly acquired vehicles } \\
\text { Acquisition of new equipment and } \\
\text { computers }\end{array}$ & & $\begin{array}{l}\text { Maintain the police enrollment rate to } \\
1,000 \text { policemen per year } \\
\text { Build } 3 \text { commissariats per year for one } \\
\text { commissariat per district } \\
\text { Strengthen the scientific and technical } \\
\text { Police, and improve the intervention } \\
\text { capacity of elements in charge of } \\
\text { community based police and Public } \\
\text { order } \\
\text { Reinforce officers corps for design, and } \\
\text { intermediate executives }\end{array}$ & $\begin{array}{l}750 \text { policemen recruited } \\
\text { Rate achieved to } 75 \% \\
\text { with only one construction } \\
38 \text { new cars of } \\
\text { interventions } \\
\text { - } 29 \text { computers; } 09 \\
\text { printers; } 03 \text { scanners; } 04 \\
\text { photocopiers and } 50 \\
\text { Typewriters } \\
\text { - } 4507 \text { new uniforms } \\
\text { Initial formation composed } \\
\text { of: } 20 \text { CP; } 30 \text { OP; } 100 \text { IP } \\
\text { and } 650 \text { AP }\end{array}$ \\
\hline
\end{tabular}

\subsection{Result Analysis}

Within the framework of the strengthening of security in urban areas, significant results were recorded, namely the setting up of an inter ministry committee and the establishment of a document of action plan against insecurity, decrease in infractions to legislation in Immigration and Emigration, reduction of drug supply, the adulterated alcohol and the securing of people . 
To reduce infractions to legislation in Immigration and Emigration, actions of intensification of territory surveillance were conducted. These actions led to a $180.38 \%$ increase in travel document controls, a $32.38 \%$ increase in the number of intelligence transmitted, a $17.48 \%$ increase in control of activities of non residents, and a $24.11 \%$ increase in visas granted. These results were obtained due to efficient prevention against underground immigrations, the improvement of prevention to violations of public order and entry refusal, as well as driving back people in irregular situations to the border.

The strengthening of drug and psychotropic substance prevention entailed the reduction in drug and the supply of adulterated alcohol. The rational organized prevention of plantations, marketing of "Rongony" through operations conducted in synergy with the decentralized local governments, and increase of about $50 \%$ in road controls resulted in an increase in drug and adulterated alcohol seizure, respectively at rates $100 \%$ and $200 \%$.

The strengthening of control of the introduction, the circulation and the allocation of weapons and ammunitions, and repression of large economic delinquency was conducted due to seizures of weapons and ammunitions used during armed thefts and money laundering prevention.

In rural areas, the confidence rate among the population improved due to the reduction of banditry actions (including cattle theft). In the course of the year 2005, tangible results were recorded, namely security among 930 communes, the set up of 216 DAS versus 118 planned ones, the establishment of 68 outposts for an objective of 11 outposts to be set up, increase of $34 \%$ in dahalo arrests, and the recovery of more than $50 \%$ of cattle stolen through a $14 \%$ increase in KIZO kept against the objective set. The relevant actions conducted relate to systematic controls of markets and of the commercial circuit of cattle, to Intensive Rural Securing operations by the Armed Forces and to mixed operations (GN-AM) in terms of security in rural areas, to road control and surveillance, to the participation of the "Gendarmerie" in drug prevention and conducting Drilling Walks for Permanent Rural Securing. Furthermore 34, 560 Common Rounds by the General Police [Tournées de Police Générale Ordinaire (TPGO)] in 22 Regions, 111 Districts, and 195,480 Joint Crosscut Rounds by the General Police [Tournée de Police Générale Croisée Conjointe (TPGCC)] in 62 red zone targeted districts were achieved.

Regarding enhanced public image of the National Police, the objective for building 03 Police stations (with police superintendent) per year was achieved only at $75 \%$, following budget cuts. Carrying forward budget items reduced the number of recruited policemen to 750 agents versus 1,000 planned. However, the police function and public image were valorized, and the safety in urban areas was improved due to the opening of 6 new proximity Police Stations and the rehabilitation of 11 buildings, the acquisition of new equipment and car fleet, giving new uniforms to urban police and FMIPN elements, and the reinforcement of transmission and communication networks. The valorization of the public image of the police had positive effects on securing people and their goods. Indeed, a $17.17 \%$ reduction in crimes in general was recorded in the year 2005. This result was obtained due to the improvement of operation modes, the training through participation in UNO security missions, to the operational capacity building among the Scientific and Technical Police and elements in charge of Public Order Keeping [Maintien d'Ordre (MO)], a quasi permanent presence of the police through motorized surveillances and patrols, an increased action scope and training for 152 elements in computerization and for 89 elements from the specialized elements regarding kidnapping and organized crime prevention.

Under the PGE, the objectives set were relatively achieved. 16 gangs were dismantled and repressed infractions to public order lowered the urban crime rate to $21 \%$ versus a $20 \%$ objective. Furthermore, highway infractions code decreased overall by $63,52 \%$ due to the lowering of the traffic, which was largely due to improved intervention methods by elements in charge road traffic, and to the increase in rounds and patrols in the order 49\%. The number of "dahalo" arrested moved from 3,926 in 2004 to 5,249 in 2005 , i.e. an increase of about $34 \%$ versus an objective of $25 \%$. Conversely, revenues in fine increased by only $30 \%$ versus a $100 \%$ projected one. This situation is due to the antinomy in assignments and the non implementation of texts on a new flat fine rate.

The lessons to be drawn are the following: (i) the contacts and the cooperation with technical and financial partners prove to be indispensable for the capacity building in security; (ii) given the size of the territory, contribution of everyone to security is desirable, and (iii) the lowering of the traffic flow has harmful effects because it engenders speed excess;

From these lessons, the following recommendations are put forward: first, it proves useful to integrate in all development projects a component on security; second, each commune should have a security plan; third, awareness rising should be conducted among the population for setting up a self defense based village. 


\subsubsection{Program 4. Local Governance}

In the area of decentralization, the undertaken actions aim at: (i) strengthening MDAT intervention capacities, (ii) turning communes and regions into development actors, (iii) strengthening the financial capacities of local governments, and (iv) strengthening CTD competences in community based resource management.

\subsection{Indicators table}

Table 33: Indicators for Decentralization

\begin{tabular}{|c|c|c|c|c|}
\hline \multirow{2}{*}{$\begin{array}{c}\text { Specific } \\
\text { objectives }\end{array}$} & \multirow{2}{*}{ Indicators } & \multirow{2}{*}{2004} & \multicolumn{2}{|r|}{2005} \\
\hline & & & Objectives & Achievements \\
\hline $\begin{array}{l}\text { Build intervention } \\
\text { capacities } \\
\text { among MDAT }\end{array}$ & $\begin{array}{l}\text { Specific Indicators } \\
\text { Number of partnership conventions signed } \\
\text { Number of directorates supported } \\
\text { Intermediate indicators } \\
\text { Number of staff trained } \\
\text { PGE indicators } \\
\text { Information and documentation system set up }\end{array}$ & & $\begin{array}{l}\text { Redefine } \\
\text { MDAT tasks } \\
\text { and missions }\end{array}$ & $\begin{array}{l}\text { Functional reorganization of the MDAT } \\
05 \text { conventions } \\
06 \text { regional directions } \\
8 \text { settings formed } \\
\text { Geographical information system (GIS) } \\
\text { Operational }\end{array}$ \\
\hline $\begin{array}{l}\text { Turn } \\
\text { communes and } \\
\text { regions into } \\
\text { development } \\
\text { actors }\end{array}$ & $\begin{array}{l}\text { Specific Indicators } \\
\text { Decentralization and De-concentration Policy } \\
\text { Paper (LP2D) published } \\
\text { Number of commune officials trained } \\
\text { Number of communes supported } \\
\text { Intermediate indicators } \\
\text { Number of regional officials trained } \\
\text { - Number of PRD developed } \\
\text { - number of mayors trained } \\
\text { Number of co operations supported } \\
\text { Number of operational OCPI } \\
\text { Number of PCD developed } \\
\text { Number of MPP developed } \\
\text { Number of IEC sessions held }\end{array}$ & 5,273 & Adopt LP2D & $\begin{array}{l}\text { LP2D adopted } \\
1.860 \text { elected and local officer } \\
257 \text { communes } \\
198 \text { persons responsible of which: } \\
\quad \text { - } 88 \text { in regional scheduling } \\
\quad \text { - } 66 \text { in management and leadership } \\
\quad-42 \text { in Follow-up, support-advice, } \\
22 \text { PRD } \\
100 \text { mayors } \\
05 \text { co operations } \\
109 P C D \\
333 \text { MPP } \\
315\end{array}$ \\
\hline $\begin{array}{l}\text { Strengthen } \\
\text { financial capacity } \\
\text { of local } \\
\text { governments }\end{array}$ & \begin{tabular}{|l} 
Intermediate indicators \\
Study on FDL completed
\end{tabular} & & $\begin{array}{l}\text { Improve local } \\
\text { tax system }\end{array}$ & $\begin{array}{l}\text { Survey of the Local Development Fund (FDL) } \\
\text { achieved and validated }\end{array}$ \\
\hline
\end{tabular}

\subsection{Result Analysis}

In keeping with the reinforcement of MDAT intervention capacities, the main achievements consist in redefining MDAT assignments and missions and improving MDAT internal and external relations with partners.

Indeed, tangible results were obtained in 2005, namely the adoption of the new organization chart and the training of MDAT officials, the establishment of an operational Geographical Information System (GIS), the setting up of an Analysis and Prospect Center [Centre d'Analyse et Prospective (CAP)] and of an intranet network, as well as internet connection.

On the other hand, 05 partnership conventions were signed and 06 Regional Directorates were supported.

However insufficient IEC on Decentralization and the lack of activity consistency and harmonization regarding decentralization and local development were noticed during the year 2005.

In order to turn communes and regions into development actors, actions were focused on consolidating the decentralization processes, building the capacity of regional and commune officials and promoting decentralized cooperation.

To this end, the Decentralization and De-concentration Policy Paper (LP2D) was developed and validated, and support was provided to 22 regions in the development of their Regional Development Plans. The guides to PCD and to Mayors were updated. Furthermore, 257 communes benefited from 
support in legality control. 1,860 elected people and commune officials and 198 regional officials were trained. Monitoring, guidance and control actions to local governments were undertaken, as well as promoting decentralized cooperation and citizen participation in local matters.

As regards financial capacity building among local governments, achievements involve improved local tax returns through an operational interministerial task force and the establishment of the Local Development Funds. In addition more than 17.2 billion Ariary of subsidies were allocated to communes and regions.

Two points are worth highlighting:

- A delay was recorded for the start of the overall training particularly in the provinces of Fianarantsoa and Toliara because of a problem in harmonizing and finalizing the training modules.

- A lag problem led to changes in the orientations of some PRDs.

The challenges consist therefore in providing consistency and harmonization of activities in decentralization and local development, in better integrating the land management dimension into the PRDs and in having an operational Local Development funds in 2006.

On the other hand, the following are recommended:

- Regarding the Monitoring Evaluation Method adopt one single template for reports and to agree on the various monitoring structures.

- Regarding the development and the implementation of PGE: ensure better coordination in the development and implementation of assignments which involve two (02) or several Ministries (case of local tax returns and Local Development) and coordinate the contribution of donors regarding national objectives (e.g. developing PCDs).

\subsubsection{Subprogram: De concentration}

In de concentration, the objective is to strengthen capacities in intervention, guidance and support among de concentrated services

\subsection{Indicators table}

Table 34: Indicators for De concentration

\begin{tabular}{|l|l|l|l|l|}
\hline \multicolumn{1}{|c|}{ Specific objectives } & \multicolumn{1}{|c|}{ Indicators } & 2004 & \multicolumn{1}{c|}{ Objectives } & \multicolumn{1}{c|}{ Achievements } \\
\cline { 2 - 4 } $\begin{array}{l}\text { Set up the new } \\
\text { territorial } \\
\text { administration } \\
\text { structure }\end{array}$ & $\begin{array}{l}\text { CAA Geographical } \\
\text { coverage rate } \\
\text { Adoption of texts }\end{array}$ & $\begin{array}{l}\text { Ensure CAA geographical } \\
\text { coverage }\end{array}$ & $\begin{array}{l}62 \% \\
\text { Decree } n^{\circ} 2005-012 \text { on January 11, 2005 on } \\
\text { the creation of Districts and Administrative } \\
\text { subdivisions adopted }\end{array}$ \\
\hline $\begin{array}{l}\text { Build intervention and } \\
\text { guidance capacity of } \\
\text { de concentrated } \\
\text { services }\end{array}$ & $\begin{array}{l}\text { Number of training } \\
\text { sessions completed }\end{array}$ & & $\begin{array}{l}\text { Training sessions in the } 6 \\
\text { provinces }\end{array}$ & Four training sessions \\
\hline $\begin{array}{l}\text { Rehabilitate the office } \\
\text { of the State } \\
\text { administrative } \\
\text { circumscription }\end{array}$ & $\begin{array}{l}\text { Number of repaired } \\
\text { buildings }\end{array}$ & $\begin{array}{l}\text { Repair the district and } \\
\text { administrative offices }\end{array}$ & Buildings of five Districts repaired \\
\hline
\end{tabular}

\subsection{Result Analysis}

Achievements include the setting up of a new structure of Territory Administration, building capacities in intervention and guidance among services, and rehabilitation of the State administrative district offices.

Regarding the establishment of the new Territory Administration structure, Decree $n^{\circ} 2005-012$ of January 11, 2005 establishing the Districts and Administrative subdivisions (arrondissements) was adopted. All District Head Officers were appointed and 65 new agents for the CAA posts were recruited.

Regarding capacity building among the Territory Administration executives, training in legality control was provided to Region and District officials in five provinces (Mahajanga, Toliara, Fianarantsoa, Antsiranana and Toamasina).

During the year 2005, District and administration subdivision offices in Morondava, Ambovombe Androy and among 03 Districts in the town of Antananarivo were repaired.

Notice that: 
- Credit freezing limited the achievement of programs which were established in advance (e.g. purchase of computer equipment and software, development of a thematic manual, rehabilitation of offices ...);

- Capacity building and/ or level updating among executives and agents in the Administration (Directors, Heads of District, Heads of department, Heads of Arrondissement) must be systematic.

- The frequent movements of CAA across Regions and Districts make it difficult to undertake their census (new assignment to a post, abrogation, death,)

The challenges for 2006 consist in ensuring effective state presence all over the Territory $(75 \%$ geographical coverage rate in CAA, and $100 \%$ coverage rate among Heads of District) and in providing training in legality control among Heads of District in other Regions.

The appointment, in 2006 and 2007, of officials for the 435 CAA posts planned in 2005 is to be recommended.

\subsubsection{Performance of large projects}

Overall, the achievements are on a good track regarding execution of large projects, namely the Program of Governance and Institutional Development (PGDI/IDA), PNUD DAP1, USAID ACORDS, and CREAM. PDGI intervened in the effective establishment of BIANCO, in the enhancement of public finance management, in the reinforcement of legal and judiciary frameworks in Madagascar, and in building the capacity of regions. The projects called PNUD DAP1, USAID, and ACORDS provided support to the decentralization process. The USAID Program on Governance Improvement in Targeted Areas is supporting the participative process and the civil society in regions.

\subsection{ECONOMY}

\subsubsection{Program 5. Macroeconomic Stability and Growth}

\subsubsection{Subprogram: Economy and budget}

The economy and budget are made up of five specific objectives: (i) develop the mid term macroeconomic framework and forecasts compatible with the poverty reduction strategy and maintaining the large balances; (ii) have instruments to analyze, coordinate, monitor and evaluate the sectoral and regional development policies and strategies; (iii) implement a reliable information system, required for knowing the economic and financial situation of the country; (iv) establish a budget policy as an instrument for the orientation and promotion of economy, resulting in an increase of the incomes and a control over public expenditures which are in compliance with the priority global and sectoral objectives; $(v)$ update and implement the privatization program in an optimal manner.

\subsection{Indicators table}

Table 35: Indicators for Economy and Budget

\begin{tabular}{|c|c|c|c|c|}
\hline \multirow{2}{*}{ Specific objectives } & \multirow{2}{*}{ Indicators } & \multirow{2}{*}{2004} & \multicolumn{2}{|r|}{2005} \\
\hline & & & Objectives & Achievements \\
\hline $\begin{array}{l}\text { Develop the medium term } \\
\text { macroeconomic forecast and } \\
\text { framework that complies with the } \\
\text { poverty reduction strategy and with } \\
\text { balance maintaining }\end{array}$ & $\begin{array}{l}\text { Macroeconomic } \\
\text { framework } \\
\text { document }\end{array}$ & $\begin{array}{l}\text { Framework of the } \\
\text { LF 2005 and } \\
\text { CDMT 2005-2007 } \\
\text { published }\end{array}$ & $\begin{array}{l}\text { Publish the LF } \\
2005 \quad \text { and } \\
\text { CDMT 2005- } \\
2007\end{array}$ & $\begin{array}{l}\text { Justification and } \\
\text { CDMT published }\end{array}$ \\
\hline $\begin{array}{l}\text { Acquire instruments to analyze, } \\
\text { coordinate, monitor and evaluate } \\
\text { sectoral and regional development } \\
\text { policies and strategies }\end{array}$ & $\begin{array}{l}\text { Instruments } \\
\text { developed and } \\
\text { extended }\end{array}$ & $\begin{array}{l}\text { Methodology } \\
\text { defined }\end{array}$ & $\begin{array}{l}\text { Studies } \\
\text { finalized }\end{array}$ & $\begin{array}{l}\text { Manual of follow-up- } \\
\text { assessment of the } \\
\text { programs / projects } \\
\text { published }\end{array}$ \\
\hline $\begin{array}{l}\text { Implement a reliable information } \\
\text { system which is necessary for the } \\
\text { knowledge of the country's economic } \\
\text { and financial situation }\end{array}$ & $\begin{array}{l}\text { Economic and } \\
\text { financial information } \\
\text { system operational } \\
\text { Reliable statistics }\end{array}$ & $\begin{array}{l}6 \text { main treasury } \\
\text { offices connected } \\
\text { via Internet }\end{array}$ & & \\
\hline $\begin{array}{l}\text { Implement a budget policy as an } \\
\text { instrument for orienting and promoting } \\
\text { the economy implying an increase of } \\
\text { the incomes and a control of public } \\
\text { expenditures complying with overall } \\
\text { and sectoral priority objectives }\end{array}$ & $\begin{array}{l}\text { Public finance } \\
\text { progress rate } \\
\text { Ratio revenue to } \\
\text { GDP } \\
\text { term of payment for } \\
\text { suppliers }\end{array}$ & $\begin{array}{l}\text { Finalize texts and } \\
\text { organic laws on } \\
\text { public finance } \\
11.2 \% \\
\text { Clearing through } \\
\text { PABU/UE and } \\
\text { PRSC }\end{array}$ & $11.6 \%$ & $10,5 \%$ \\
\hline
\end{tabular}




\begin{tabular}{|c|c|c|c|c|}
\hline \multirow{2}{*}{ Specific objectives } & \multirow{2}{*}{ Indicators } & \multirow{2}{*}{2004} & \multicolumn{2}{|r|}{2005} \\
\hline & & & Objectives & Achievements \\
\hline & $\begin{array}{l}\text { Budget share } \\
\text { allocated to social } \\
\text { sectors: education, } \\
\text { health }\end{array}$ & $\begin{array}{l}23.41 \% \\
8.34 \%\end{array}$ & $\begin{array}{l}21.05 \% \\
8.6 \%\end{array}$ & $\begin{array}{l}21,28 \% \\
7,89 \%\end{array}$ \\
\hline $\begin{array}{l}\text { Update and optimally execute the } \\
\text { privatization program }\end{array}$ & $\begin{array}{l}\text { Number of } \\
\text { operations closed }\end{array}$ & & & \\
\hline
\end{tabular}

\subsection{Result Analysis}

Economic growth performance declined in 2005 compared with the objective of the year and with the achievement of the previous year. This counter performance originates from a number of factors, including the continuous increase in energy prices and JIRAMA cash flow problems, which resulted in frequent power cuts. Such power outage disrupted very much the economic activity.

As public incomes are strongly related to production, their decline for whatever reasons entails inevitably a shortfall. The above mentioned counter performance is, amongst others, at the origin of the low level of fiscal pressure for the year 2005.

As the target in economic policy is macroeconomic stability, facing the above mentioned disruptions, actions were taken in the budget and monetary area.

As regards public finance, cuts in expenditures were observed and efforts were deployed in tax recovery (customs, duties). Similarly, to fulfill its needs, the State resorted to domestic loans (BTA...). The purpose is to reduce public finance deficit. All such measures decreased financing needs in the public sector and indirectly the nation's needs for funds, but they also reduced the household financing capacity and increased financing needs among enterprises.

The deterioration in tax revenues thus weighed on public debt which, in addition to the depreciation of the exchange rate, made up one of the factors leading to the high inflation rate. This inflationist tension will have an impact on the interest rate, therefore, on investment.

Some realities which were listed above somehow disrupted the public finance reform program while positive results were recorded in the public treasury. The lack of revenues had negative impacts on budget planning and execution.

Despite constraints, the Government observed its commitments in terms of the poverty reduction strategy. Significant budget was allocated to the Ministry of education and the Ministry of Health, and such sectors were spared from cuts in expenditures.

To boost its economy, Madagascar must produce cheaper goods, i.e. good quality and lower price ones. To achieve such a goal, judicious use of all existing (human, financial, and natural) resources, the public investment program, and tax policy will have to provide tools to reach this target.

\subsubsection{Program 6. Development of Key Growth Sectors}

\subsubsection{Subprogram: Tourism}

\subsection{Indicators table}

For the year 2005, the Tourism sector set the following specific objectives (i): diversify, valorize tourism products and promote Madagascar as a destination to convince travel companies and international travelers, (ii): standardize activities, buildings, tourism products and sites to make them competitive, (iii): keep Madagascar as a healthy destination by preventing common tourism blights: sexual tourism, drug, pedophilia, AIDS, sexual exploitation of children, (iv): make Madagascar a safe destination through the control of tourism activities bearing risks to humans and the environment, and (v):Promote investment and develop tourism infrastructure and ensure good governance in the sector.

Table 36: Indicators for Tourism

\begin{tabular}{|c|c|c|c|c|}
\hline Specific objective & Indicator & $\begin{array}{c}2004 \\
\text { Achievement }\end{array}$ & $\begin{array}{c}2005 \\
\text { Objective }\end{array}$ & $\begin{array}{l}\text { Achievement } \\
2005\end{array}$ \\
\hline \multirow[t]{2}{*}{$\begin{array}{l}\text { Diversify, valorize tourism products and } \\
\text { promote Madagascar as a destination }\end{array}$} & $\begin{array}{l}\text { Incoming foreign currency amount per year (in MGA } \\
\text { Billions) }\end{array}$ & 288 & 252 & 343 \\
\hline & Number of foreign tourists per year & 228,784 & 250,000 & 277,000 \\
\hline \multirow{2}{*}{$\begin{array}{l}\text { Standardize tourism activities, } \\
\text { buildings, products and sites to make } \\
\text { them competitive }\end{array}$} & Number of standardized buildings per year & & 200 & \\
\hline & Number of establishments labeled and certified & & 100 & \\
\hline
\end{tabular}


2005 PRSP Progress Report

\begin{tabular}{|c|c|c|c|c|}
\hline Specific objective & Indicator & $\begin{array}{c}2004 \\
\text { Achievement }\end{array}$ & $\begin{array}{c}2005 \\
\text { Objective }\end{array}$ & $\begin{array}{c}\text { Achievement } \\
2005\end{array}$ \\
\hline \multirow{2}{*}{$\begin{array}{l}\text { Make Madagascar a healthy } \\
\text { destination through tourism blight } \\
\text { prevention }\end{array}$} & Decrease in tourism blights & & Non available & Non available \\
\hline & Number of tourists involved in sex tourism and drug & & $0.1 \%$ & \\
\hline \multirow{2}{*}{$\begin{array}{l}\text { Make Madagascar a safe destination } \\
\text { by controlling tourism activities that are } \\
\text { potentially risky for human beings and } \\
\text { the environment }\end{array}$} & Number of tourists involved in incidents or accidents & & 10 & Non available \\
\hline & $\begin{array}{l}\text { Number of environmental permits issued to tourism } \\
\text { businesses }\end{array}$ & & 5 & $\begin{array}{r}6 \text { EIE } \\
5 \text { PREE }\end{array}$ \\
\hline \multirow{7}{*}{$\begin{array}{l}\text { Promote investment and develop } \\
\text { tourism infrastructure }\end{array}$} & New jobs created & 1,155 & 1,000 & 1,322 \\
\hline & New travel companies authorized & 36 & & 124 \\
\hline & New accommodation and restaurant buildings & 129 & & 84 \\
\hline & New operational rooms & 905 & 500 & 649 \\
\hline & File processing duration (days) & 25 & 10 & 20 \\
\hline & Number of investment project files processed & & 200 & 208 \\
\hline & Number of RFT put to disposal & & & 6 \\
\hline \multirow[t]{2}{*}{ Ensure good governance in the sector } & TMP validated and presented to donors & & 1 & 1 \\
\hline & Number of checks conducted & & & \\
\hline
\end{tabular}

EIE: Environmental Impact Study

PREE: Environmental Commitment Program

\subsection{Result Analysis}

- Incoming Foreign currency and international tourist arrival number: An increase in the foreign currency income and the number of international tourists was recorded, with an average of about $17 \%$ to $21 \%$ between 1996 and 2001 . The trend is maintained for the number of tourists which also increased by $21 \%$ in 2005 . The increase in income clearly improved because it rose to $19 \%$ in 2005.

- The 2005 objectives for both indicators were exceeded

- What contributed to such results is the development of ecotourism, boosting the promotion scheme by operationalizing the National and Regional Tourism Offices, promotion of Madagascar destination thanks to the promotion of the film "Coast to Coast", guides, brochures, web site, the participation of Madagascar in international and regional tourism events, as well as the identification of new tourism sites in the regions of Analamanga, Vakinankaratra, and Vatovavy Fitovinany..

- Jobs created: between the years 1997 and 2001, tourism generated jobs, of which the annual increase rate was around $40 \%$. Following the 2002 crisis, the job rate only increased by $5 \%$ between 2003 and 2004 and reached 14\% between 2004 and 2005. The 2005 objective is reached. This improvement is explained by a significant increase in authorized new travel agencies, by the number of new operational rooms, for which the target was exceeded, and by improved file processing in GUIDEs.

- Standardization: guides for standards and classification were developed and distributed, and a sensitization campaign was conducted regarding standards, as well as training in sustainable tourism. Activities in Green Label grading, which were conducted with the Chambers of Commerce, are being started. Ten sites are involved therein: Antananarivo, Antsirabe, Ranomafana, Toamasina, Nosy Be, Antsiranana, Toliary, Toamasina, Sainte Marie. Grading activities for sustainable tourism, conducted with ONE, are also being started.

- The objective to make an "environment friendly" tourism industry is largely exceeded. Sensitization actions for preventing tourism blights were conducted in several towns. Risk activities, as well as tourism sites bearing risk activities were identified and classified. On the other hand, the sites where to implement the program on sustainable tourism were identified: Anakao, Toliary I, Ifaty, Beheloka, and Soalary...

The main lessons learnt involved the necessity to have available, reliable, and up to date information, the still expensive air transportation fees, the inexistent infrastructure in tourism zones and insufficient budget for promoting tourism, the standardization of tourism activities and establishments and clearing of State owned hotels.

The following challenges must therefore be met: set up the intranet and extranet network of the Ministry and set up the agency for the promotion of tourism investment which is in harmony with GUIDEs; strengthen the open sky policy, prioritize tourism sites/infrastructure rehabilitation in the development program, namely in transport and sanitation; establish an adequate financing mechanism for tourism and effectively implement the Tourism Master Plan. 


\subsubsection{Subprogram: Mining}

\subsection{Indicators table}

The specific objectives assigned to the mining sector for the year 2005 consist in increasing the mining sector contribution to national value added, providing a sound and safe environment to the mining sector and related industries, and reducing the smuggling of mineral substance

Table 37: Indicators for Mining

\begin{tabular}{|c|c|c|c|c|}
\hline Specific objective & Indicator & $\begin{array}{c}2004 \\
\text { Achievement }\end{array}$ & $\begin{array}{c}2005 \\
\text { Objective }\end{array}$ & $\begin{array}{c}2005 \\
\text { Achievement }\end{array}$ \\
\hline \multirow{5}{*}{$\begin{array}{l}\text { Increase the contribution of the mining } \\
\text { sector to the national value added }\end{array}$} & Mining investments (in US\$ Millions & 354 & 458 & 542 \\
\hline & Mining royalties collected (in MGA Millions) & 207 & 270 & 336 \\
\hline & Mining administration fees (in MGA Millions) & 212 & 1,700 & 3,177 \\
\hline & $\begin{array}{l}\text { Mineral substance export value (in US\$ } \\
\text { Millions) }\end{array}$ & 30 & 45 & 104 \\
\hline & Large mining investment decisions & & 2 & 1 \\
\hline $\begin{array}{l}\text { Ensure a safe and sound environment } \\
\text { for the mining sector and related } \\
\text { industries }\end{array}$ & $\begin{array}{l}\text { Number of authorizations granted to private } \\
\text { organizations that undergo the official test on } \\
\text { gas pressure or steam device }\end{array}$ & & 2 & 0 \\
\hline $\begin{array}{l}\text { Reduce the rate of mineral products } \\
\text { smuggling }\end{array}$ & Reduced number of infractions & & & \\
\hline
\end{tabular}

\subsubsection{Result Analysis}

Satisfactory results were recorded in the following:

- Mining Investment: a significant improvement in mining investment was recorded for the year 2005. They indicate a $70 \%$ increase in value compared with an annual average increase of $30 \%$ between 1996 and 2004... Furthermore, the objective set for 2005 is largely exceeded.

- $\quad$ Mining royalties collected: they increased by $62 \%$ compared with 2004.and the objective targeted in 2005 was exceeded, as well as for that of mining administration fees.

- $\quad$ Mining Substance Export: Mining substance export indicated a remarkable increase close to 246 \% compared with 2004, whereas the annual increase was only $11 \%$ between 1996 and 2004 . The objective set for 2005 was largely exceeded.

These results were essentially due to the following:

- Strengthened sensitization and awareness raising actions among operators along with efforts for setting up and strengthening transparency and good governance through the biannual publication of the list of license holders, together with the royalties, improved Mining Legislation and Large Mining Investment Act, as well as setting up the Base for Promoting the Governance of Mining Resources (equipment, training). On the other hand, the enforcement of regulatory texts pertaining to legal action against non performing operators is under way. Promotion of decentralized management of mineral resources through strengthened activities by the "Bureau de Cadastre Minier" in income collection

- Promotion of private investment in the mining sector: efforts related to skill building among IGM students and artisans in gemology and lapidary activities through long term courses at the Madagascar Gemology Institute or itinerary training provided in Antsirabe, Maevatanana and Betroka.

- As regards to ensuring a sound and safe environment for the sector and related industries, no result has been achieved yet in granting licenses to organizations which are called to test the gas or steam pressure materials. As the first step is reviewing the texts regulating the gas or steam pressure materials and explosive or detonating substances, gathering existing texts and legislation all over the world had to be done first. The study on licensing procedure is started.

- As regards reduction of mineral substance smuggling, 39 inspections and unexpected visits were undertaken during the operation called "DIO SEHATRA" (a clearing operation) which allowed seizing about 12 tons of substances.

The main lessons learnt are related to the delay, or even the insufficiency of information and scientific data exchange in this sector, the lack of technical knowledge among mining artisans and the poor participation of the mining sector in tax incomes.

The challenges thus consist in developing geological, digital maps and accelerating the establishment of intranet and extranet networks; professionalizing mining artisans, namely through training of gold 
washers and collectors in all pilot communes, providing short courses in gemology and lapidary works in the regions, and financial support to mining artisans; pursuing the reinforcement of mining cadastre offices; developing and establishing a strategic and operational plan to reduce mineral substance smuggling.

\subsubsection{Subprogram: Fishery}

\subsection{Indicators table}

The specific objective in the Fishery sector is strengthening the collaboration with technical and financial partners to ensure a transparent and rational management of fishing resources and ensure their sustainability.

Table 38: Indicators for Fishery

\begin{tabular}{|c|c|c|c|c|}
\hline Specific objective & Indicator & $\begin{array}{c}2004 \\
\text { Achievement }\end{array}$ & $\begin{array}{c}2005 \\
\text { Objective }\end{array}$ & $\begin{array}{c}2005 \\
\text { Achievement }\end{array}$ \\
\hline \multirow{2}{*}{$\begin{array}{l}\text { Ensure a transparent and rational } \\
\text { management of fishing resources and } \\
\text { ensure their sustainability }\end{array}$} & Fishing production volume $(\mathrm{t})$ & 139,008 & 141,130 & Not available \\
\hline & $\begin{array}{l}\text { Income/royalties (fees) volume in the } \\
\text { area of fisheries and aquaculture (in } \\
\text { MGA Billions) }\end{array}$ & 6.88 & 7.02 & 11.30 \\
\hline
\end{tabular}

\subsection{Result Analysis}

The fees/royalties amount collected in 2005 indicated a $64 \%$ increase compared to 2004 . The $2 \%$ annual increase objective is thus largely exceeded. This performance is explained by a strong increase in the 2004 yield, the high number of fishing licenses, prospecting licenses, and collection permits issued, as well as by the impact of semester publications in the media of the lists of fishing license holders with the status of royalty payment.

The fishing production: the 2005 achievement status is not available yet. The data are being collated. The actions to promote fishing production relate to sustainable management and resource operating (establishment of joint area management zones (Zones d'aménagement concerté), implementation of GELOSE in continental and marine fishery, fish stock restoration in water tables, establishing compatibility of fishery with the environment, and capacity building for technical agents, fishing people and aquaculture people.

\subsubsection{Subprogram: Manufacturing Industries}

\subsection{Indicators table}

As an interest bearing sector, the manufacturing industry sector sets specific objectives for promoting foreign and domestic direct investment, on the one hand, and promoting partnerships between the Government and the Private Sector in handicraft and manufacturing industry sectors, on the other hand.

Table 39: Indicators on Manufacturing Industries

\begin{tabular}{|c|c|c|c|c|}
\hline Specific objective & Indicator & $\begin{array}{c}2004 \\
\text { Achievement }\end{array}$ & $\begin{array}{c}2005 \\
\text { Objective }\end{array}$ & $\begin{array}{c}2005 \\
\text { Achievement }\end{array}$ \\
\hline \multirow{4}{*}{$\begin{array}{l}\text { Promote foreign and domestic direct } \\
\text { investment }\end{array}$} & Jobs created & 10,935 & 12,000 & 9,395 \\
\hline & $\begin{array}{l}\text { Investment injected in EPZs (in MGA } \\
\text { Millions) }\end{array}$ & 66 & 90 & 99 \\
\hline & Number of EPZ files authorized & 23 & 50 & 15 \\
\hline & $\begin{array}{l}\text { Number of companies set up in ZFI } \\
\text { Toamasina (Tsarakofafa) }\end{array}$ & - & 10 & - \\
\hline \multirow{2}{*}{$\begin{array}{l}\text { Promote partnerships between the } \\
\text { Government and the private sector in } \\
\text { handicraft, and manufacturing } \\
\text { industries }\end{array}$} & $\begin{array}{l}\text { Number of craftsmen trained and } \\
\text { formalized }\end{array}$ & 400 & $\begin{array}{r}50 \\
0\end{array}$ & 900 \\
\hline & $\begin{array}{l}\text { Number of craftsmen / factories having } \\
\text { obtained the label of quality }\end{array}$ & 07 & 10 & 15 \\
\hline
\end{tabular}

\subsection{Result Analysis}

Compared with achievements in 2004, despite growth in EPZ investments, which is close to $33 \%$, a $53 \%$ decline in the number of licensed EPZ companies, and therefore a $16 \%$ reduction in job creation 
was recorded. In parallel, the 2005 objective in EPZ investments was exceeded but the objectives targeted in licensed EPZ companies and job creation were not achieved.

The performance in EPZ investment is due to identification and servicing of manageable areas into industrial areas, finalization of the bill on EPZs and setting up of the EPZ observatory.

The dismantling of the Multi Fiber Agreement and the issue of power outages, which were very common in 2005, were the causes of the decline in number of new licensed EPZ companies.

On the other hand, the number of craftsmen who were formalized and provided with technical and managerial skills has more than doubled. Such a fact obviously contributed to the increasing number of quality label artisans and industrial enterprises, which doubled in comparison with 2004.

As regards the ZFI of Tsarakofafa (Toamasina), all surveys are completed, the off-site management was undertaken and the developer is selected. But the legal resolution of the developer is still expected, as well as improvements in contracts relating to the schedule for executing the obligations, and it is necessary to establish a clear separation between any work on the zones involved and the developer commitments

The lessons learnt involve namely the required level for maximum information on the prospective developer during the management of dedicated industrial zones, the general lack of knowledge on cooperatives, and the necessity to de-concentrate support and information services.

The main challenges then consist in accelerating the selection of the developer following the survey and the management of the dedicated industrial zone, extending information on cooperatives to operators, partners and decision makers; and multiplying EPA (Espaces Promotion de l'Artisanat) (Handicraft Promotion Spaces) centers in regions.

\subsubsection{Program 7. Rural Development}

The overall objective is to boost rural development while preserving and valorizing the environment; and the present Program includes 2 subprograms, i.e. the Agriculture and Livestock Subprogram, and the Environment, Water and Forest Subprogram

\subsubsection{Subprogram: Agriculture and Livestock}

\subsection{Indicators table}

The specific objectives set by the Ministry in charge of agriculture and livestock consist in (i) facilitating good governance in the agricultural sector; (ii) promoting diversification and processing of agricultural products by encouraging investment in rural areas, and partnership between farmer organizations, village based associations, and the private sector; (iii) reaching the international quality standards for developing agricultural and agro industrial export; (iv) increasing agricultural productivity, and finally (v) facilitating access to land ownership.

Table 40: Indicators for Agriculture and Livestock

\begin{tabular}{|c|c|c|c|c|}
\hline Specific objective & Indicator & $\begin{array}{c}2004 \\
\text { Achievement }\end{array}$ & $\begin{array}{c}2005 \\
\text { Objective }\end{array}$ & $\begin{array}{c}2005 \\
\text { Achievement }\end{array}$ \\
\hline $\begin{array}{l}\text { Ensure good governance in agricultural } \\
\text { sector }\end{array}$ & Progress rate of institutional reform & $15 \%$ & $50 \%$ & $40 \%$ \\
\hline $\begin{array}{l}\text { Promote the diversification and the } \\
\text { processing of farming products by } \\
\text { encouraging investment and partnership }\end{array}$ & Number of emergent clusters & 13 & 5 & 5 \\
\hline $\begin{array}{l}\text { Tend to compliance with international quality } \\
\text { standards to develop agricultural and agro } \\
\text { industrial exports }\end{array}$ & $\begin{array}{l}\text { Agricultural export values (in MGA } \\
\text { Billions) }\end{array}$ & 619,250 & 835,990 & 529,690 \\
\hline \multirow[t]{6}{*}{ Increase agricultural productivity } & Rice production volume $(\mathrm{T})$ & 3.030 .000 & 3.400 .000 & 3.420 .000 \\
\hline & Rice yield (t/ha) & 2,42 & 2,60 & 2,57 \\
\hline & Cattle head number & $8,109,480$ & $9,000,000$ & Non available \\
\hline & Bovine anthrax vaccination rate & $75 \%$ & $\geq 80 \%$ & $78 \%$ \\
\hline & $\begin{array}{l}\text { Area invaded by locusts and chemically } \\
\text { treated (ha) }\end{array}$ & $\begin{array}{r}67,538 \\
(80 \%)\end{array}$ & $(80 \%)$ & $\begin{array}{r}138,450 \\
\left(90 \%{ }^{\circ}\right.\end{array}$ \\
\hline & Credit Outstanding (in MGA Millions) & 19,429 & 50,000 & 35,979 \\
\hline \multirow[t]{3}{*}{ Facilitate access to land ownership } & Secured farming area (ha) & Non available & Non available & Non available \\
\hline & Farming businesspeople registration rate & Non available & $30 \%$ & $0 \%$ \\
\hline & Number of land titles issued & 1,800 & 15,000 & 13,700 \\
\hline
\end{tabular}




\subsection{Result Analysis}

The institutional reform progress rate is measured from the achievements in anticipated voluntary retirement amongst the personnel, training, and agent redeployment. Progress is recorded compared with 2004, and the objective set for 2005 was achieved at $80 \%$, thanks to the achievements related to the training of "at work" agents and the recruitment plan, while agent redeployment still remains to be improved.

But in keeping with good governance in the sector, other relevant achievements are to be noted, namely the development of 4 policy documents (Land Tenure Policy Paper, Rural development Policy Paper; National Strategy for the Development of the Cotton Cluster, Livestock Sector Policy Paper), the establishment of 4 new Regional Rural Development Head Offices (Betsiboka, Androy, Atsimo Atsinanana and Itasy) and the implementation of 13 accounting procedure and organizational audits..

Rice production indicated progress. From $8 \%$ in 2004 , it increased to a $13 \%$ rate in 2005 . In parallel, the objective was reached.

Similarly, from $3 \%$ in 2004, the rice yield increased up to $6 \%$ in 2005 but did not reach the objective of $8 \%$. The average rice yield level is still low. Between the 60 s and the year 2000 , it developed by only $1.8 \mathrm{t} /$ ha to $2 \mathrm{t} / \mathrm{ha}$, and reached $2.57 \mathrm{t} /$ ha in 2005 .

Improvement in rice production and output was especially favored by the following: good climate conditions; technical and management support to farmers' associations, namely by the following projects: PSDR (Rural Development Support Project), PSSA (Food Security Specific Project), PHBM (Mandrare Watershed Project), and PADANE; rehabilitation of hydro agricultural networks and maintenance of irrigation canals: (good water control in 88,000 ha); organization of agricultural contests encouraging the use of the best production techniques; funding agricultural subprojects from PSDR; microfinance credits; and road infrastructure development.

But various factors further explain this still low output level and the gap against the set objective: insufficient production factors made available for producers (fertilizers, improved seeds, funding/credits, and agricultural equipment); inadequate water control; low rate in adoption of improved techniques and in promotion of rain fed rice cultivation, the output of which is lower than for water fed rice cultivation.

The cattle immunization rate recorded progress, and the objective set for 2005 is nearly reached although information from some areas is not available. What contributed to these results was the training provided to technicians in animal health, as well as the construction / rehabilitation of immunization corridors (PHBM)

Between 2003/2004 and 2004/2005, the rate of treating areas which were invaded by locusts developed from $80 \%$ to $90 \%$, i.e.; doubling. The treating of areas that were invaded by locusts involved the regions of Androy (Ambovombe), Anosy (Betroka), Atsimo Andrefana (Toliara II, Sakaraha, Ampanihy), and Sofia (Antsohihy). The set objective was exceeded thanks to the use of pesticides and the strengthening of anti-locust watch system through communication materials.

For 2005 , the credit outstanding indicated a net progress close to $85 \%$ versus a $27 \%$ value increase in 2004. The credit outstanding objective was achieved at $72 \%$. The relevant actions contributing to such a result are namely the promotion of decentralized financial systems, as well as the facilitation and sensitization actions among grassroots farmers in various financial service types provided by microfinance institutions. The gap against the set objective would be explained by the fact that achievements relate only to mutual financial institutions, whereas the objective involves all financial institutions, and achievements relating to non mutual financial institutions are not available.

The targeted objective regarding emergent sectors was achieved and includes litchi (Analanjirofo, Atsinanana), shrimp breeding (Alaotra Mangoro, Betsiboka), silk (Analamanga), onion (Analamanga) and potato (Vakinankaratra). These are emergent clusters managed by professionals. These results were achieved thanks to partnerships established between producers and operators, improved producers' access to markets, strengthened skills among producers and the Administration, which was undertaken in the Agricultural Export Boosting Project, infrastructure subprojects funding, to agricultural and non agricultural activities by PSDR and transfers of agricultural equipment such as ploughs, harrows, weeding hoes, and mini tractors to producers and farmer organizations by some Projects: OPMA (Small agricultural Material Operation), PSDR and PHBM.

The number of land titles established in 2005 declined to about $23 \%$ compared to that of 2004 . The related objective for 2005 was achieved at $91 \%$. Despite the delay recorded in supply of technical and office supplies, the corresponding achievements relate to the land tenure sector reform and to the computerization of the land tenure and topography system.

The objective regarding the registration of farming businesspeople (chefs d'exploitation) involves 5 regions: Analamanga, Vakinankaratra, Menabe, Amoron'i Mania, and Haute Matsiatra. The 
identification of the $30 \%$ of farming businesspeople corresponding registers was identified but neither the registration of farming business people. nor the land titles seizures could be started due to the pending acquisition of the software for land title registration and the organization of the training of agents, following credit freezing.

Compared with 2004, agricultural export values declined by $15 \%$.

The main constraints were the following: non mastering of the new procedures related to the program budget, difficulty to collect and to forward information from off center entities, low agricultural output level, especially that of the national average in rice, and vanilla export price fall.

Consequently, the measures below are of prime importance: continuation of training and permanent support to ORDSECs and GACs; development of community based services and extension of the intranet network; improvement in input supply: improved seeds, and small agricultural equipment, as well as promotion of small agro-industries; promotion of the standardization, and diversification of export products; periodical rehabilitation of rural tracks and extension of the area covered by rural electrification, which are indispensable for promoting the communication and information system, as well as for developing small agro-industries.

\subsubsection{Subprogram: Environment, Water, and Forests}

\subsection{Indicators table}

The specific objectives for this subprogram are: (i) ensuring good governance at all levels of accountability, (ii) increasing the surface of protected areas and conservation sites, (iii) preserving and valorizing the importance and the quality of natural resources for sustainable economic growth and a better life quality, (iv) fulfilling the economic and ecological needs of the population in forest, soil, and water resources, (v) mainstreaming the environmental dimension in sector development policies and actions, and in local, commune, and region planning.

Table 41: Indicators for the Environment, Water and Forestry

\begin{tabular}{|c|c|c|c|c|}
\hline Specific objective & Indicator & $\begin{array}{c}2004 \\
\text { Achievement }\end{array}$ & $\begin{array}{c}2005 \\
\text { Objective }\end{array}$ & $\begin{array}{c}2005 \\
\text { Achievement }\end{array}$ \\
\hline $\begin{array}{l}\text { Ensure good governance at all responsibility } \\
\text { levels }\end{array}$ & $\begin{array}{l}\text { Number of infractions / } \\
\text { number of controls }\end{array}$ & $6 / 6$ & $9 / 9$ & $9 / 9$ \\
\hline $\begin{array}{l}\text { Increase the surface of protected area and } \\
\text { conservation sites }\end{array}$ & $\begin{array}{l}\text { Surface of protected areas } \\
\text { (ha) }\end{array}$ & 500,000 & $1,000,000$ & $1,050,000$ \\
\hline $\begin{array}{l}\text { Conserve and promote the importance and the } \\
\text { quality of natural resources to allow sustainable } \\
\text { economic growth and better quality of living }\end{array}$ & $\begin{array}{l}\text { Number of management } \\
\text { plans implemented }\end{array}$ & & 2 & 2 \\
\hline \multirow{2}{*}{$\begin{array}{l}\text { Fulfill the population social, economic and } \\
\text { environmental needs in forest resources, soils } \\
\text { and water }\end{array}$} & Reforested area (ha) & 7,300 & 50,000 & Non available \\
\hline & Burnt areas (ha) & Non available & $\leq 680,000$ & 555,938 \\
\hline $\begin{array}{l}\text { Mainstream the environmental dimension in the } \\
\text { policies and sectors development actions, as } \\
\text { well as in local, communal and regional planning }\end{array}$ & $\begin{array}{l}\text { Number of environmental } \\
\text { permits issued }\end{array}$ & 18 & 35 & 37 \\
\hline
\end{tabular}

\subsection{Result Analysis}

- Despite progress in the number of checks made, the number of CIREEFs that were covered is still fairly low. Over time, the objective would be to reduce the infraction rate while multiplying checks and extending them to all CIREEFs. Instead of monitoring the ratio of the number of infractions number/number of controls, it would be more opportune to monitor two indicators, i.e. the number of checks undertaken and the number of checked infractions.

- The number of checks targeted as the objective is achieved at $100 \%$. Checks were undertaken in the following CIREEFs: Fianarantsoa, Mainitirano, Toamasina I, Antsohihy, Ambatondrazaka, Taolagnaro, Antalaha, Ambositra, and Moramanga. They related to 102 units including artisans, woodworkers, art galleries, sale depots, and trucks.

- The objective in checked infractions is also achieved at $100 \%$. The relevant actions to be noted in that respect are the six months publication of the list of permit holders with the royalties status, the field inspections and checks in the regions of Menabe, SAVA, Analanjirofo, Amoron'i Mania, Atsinanana, Alaotra Mangoro, Andrefana, and Boeny, the establishment of a planning and 
monitoring evaluation system, and the implementation of the forest administration reform, which consists in separating the check function from design, support and monitoring evaluation functions.

- Compared with the 2004 achievements, the surface of protected areas doubled in 2005, i.e. the 2005 objective is reached. The definition of the legal and judicial framework of the protected area system, and the communication campaign in the 6 Faritany with the involvement of deconcentrated services and local decision makers in the process for creating the Protected Area System are among the pertinent actions that contributed to this achievement

- The information on burnt areas in 2004 is not available. Compared with the annual average for 2002 and 2003, the extent of burnt areas in 2005 decreased to close to $9 \%$, i.e. the reduction objective is reached. This is due to the following achievements in the year 2005: creation of 14 fire squads and 2,053 committees of fire prevention in 1,695 fokontany; the organization of sensitization campaigns and missions for checking and granting bonuses to deserving communes in fire prevention.

- The number of environmental permits has nearly doubled compared with 2004 , i.e. the objective is achieved. The relevant actions contributing to this include amongst others the existence of 6 operational MECIE resource centers (Antsiranana, Nosy Be, Antsirabe, Mahajanga, Toamasina, and Fianarantsoa), the establishment of Environmental Operating Reports (Tableaux de Bord Environnemental), and the setting up of a website.

- The indicator fixed in terms of the management plans targets all management and development plans of forest and environment based activities (forest exploitation, management transfer, ecotourism, cluster valorization ...). 2 management plans, as per the 2005 objective, were implemented. These are the integrated management plan from the Land and Water Initiative in the rural commune of Anjepy, and the management plan of the Prunus Africana cluster. Several relevant actions contributed to such results, of which the transfer of the management of natural resources to grassroots communities (close to 100,359 ha), and the development of procedures and the Streamlined Development and Management Plan as a transfer instrument; the reinforcement of the ministry environmental units; the development of planning tools: the start of the zoning process and the development of preliminary forest zoning maps; the development of cluster valorization plans, and the development of wetland management plans (6,900 ha with an interim status).

- The Foundation for Protected Area is operational at $80 \%$. The contributing factors are the legal establishment of the Foundation, the promulgation of the decree stating its public usefulness, the recruitment of the staff of the Foundation, the identification of Funds and the subscription of the initial capital of the Foundation: government: Ariary 1.1Billion; WWF: US\$1Million; Conservation International: US\$1Million

- The achievement in reforestation is not available yet. In keeping with reforestation promotion, 7 Land Reserves for Reforestation are being established, 50,000,000 young plants were produced, some ravintsara plants were distributed to 150 communes, and jatropha plants to 40 communes.

\subsubsection{Program 8 the Development and the Revitalization of the Private Sector}

The overall objective of the revitalization of the private sector, so that it participates up to 12 to $14 \%$ in the investment rate is assigned to the present program, which is divided into the Subprogram Industry, Trade and Private Sector Development.

\subsection{Indicators table}

The specific objectives of the present subprogram are the following (i): promoting domestic and foreign private investment, as well as the partnership between the government and the private sector, and (ii): fostering good governance in the sector of Industry, trade and development of the private sector

Table 42: Indicators for Industry, Trade, and Development of the Private Sector

\begin{tabular}{|c|c|c|c|c|}
\hline Specific objective & Indicator & $\begin{array}{c}2004 \\
\text { Achievement }\end{array}$ & $\begin{array}{c}2005 \\
\text { Objective }\end{array}$ & $\begin{array}{c}2005 \\
\text { Achievement }\end{array}$ \\
\hline \multirow{4}{*}{$\begin{array}{l}\text { Promote domestic and foreign private } \\
\text { investment, as well as partnership between } \\
\text { the government and the private sector }\end{array}$} & $\begin{array}{l}\text { Amount of private investments (in MGA } \\
\text { Millions) }\end{array}$ & 3,600 & 5,000 & 3,160 \\
\hline & Ratio Private investment to GDP & $12.2 \%$ & $\leq 14 \%$ & $12.3 \%$ \\
\hline & Number of enterprises created at GUIDE & 817 & 820 & 882 \\
\hline & Number of regional CAPEs set up & 05 & 02 & 02 \\
\hline $\begin{array}{l}\text { Ensure good governance in the sector of } \\
\text { industry, trade and private sector } \\
\text { development }\end{array}$ & $\begin{array}{l}\text { Execution rate in development and } \\
\text { boosting of the private sector }\end{array}$ & - & $30 \%$ & $10 \%$ \\
\hline
\end{tabular}




\subsection{Result Analysis}

The amount of private investment decreased between 2004 and 2005, and the 2005 objective was not reached. The private investment ratio to GDP increased by 0.1 ; although the related objective in 2005 was not achieved.

The number of enterprises created at the level of GUIDE increased by close to $8 \%$ between 2004 and 2005, and in parallel the 2005 objective for this indicator was exceeded. In that respect, the relevant actions consist in setting up regional GUIDE branches in Nosy Be and Taolagnaro; in reducing the number of documents required and the service costs at GUIDE in its collaboration with IG2P; in materializing partnerships; in conducting missions for extending support to the promotion of investment; deploying efforts for improving environment of business: development of the Investment Charter and the PPP Conduct Code, in publishing the Barometer of Enterprises in Madagascar (Baromètre des Entreprises à Madagascar); in securing investment through the membership of Madagascar to the Agency for Trade Insurance (Assurance du Commerce), and developing Bilateral Agreements for Investment Promotion and Protection.

The execution rate of the program for developing and boosting the private sector was only $10 \%$ versus the objective of $30 \%$, because of delay in the startup, that was linked to a problem in the procedures for official recruitment.

The main lessons learnt from this year 2005 are the following: inadequate preparation in the organization of promotion missions abroad, and the impossibility to organize training sessions in Madagascar by experts in APPI (Accords de Promotion et de Protection des Investissements) (Investment Promotion and Protection Agreements).

As a result, the challenges consist in professionalizing the missions of investment promotion abroad, and to provide for the financial resources in the budget, which are required for the capacity building in promoting APPIs.

\subsubsection{Program 9. DeVelopment ANd Intensification of Structuring INFRAStructure}

\subsubsection{Subprogram: Transports, Roads, and Meteorology}

The Ministry of Public Works and Transports is in charge of designing, implementing, and monitoring the Policy of the government in public works and transports.

The objectives are to:

- $\quad$ have a good condition road network of $14,000 \mathrm{Km}$ by 2015 ;

- $\quad$ Ensure the maintenance of the road network as a whole;

- $\quad$ promote the good functioning of railways by private enterprises;

- $\quad$ improve the quality of services in the ports of Madagascar, and to reduce the cost;

- $\quad$ encourage the development of competitive air transports;

- $\quad$ improve the meteorology and national alert systems.

\subsection{Evolution of Indicators}

Table 43: Indicators for Transports, Roads, and Meteorology

\begin{tabular}{|c|c|c|c|c|}
\hline \multirow{2}{*}{ Specific objectives } & \multirow{2}{*}{ Indicators } & \multirow{2}{*}{2004} & \multicolumn{2}{|c|}{2005} \\
\hline & & & Objectives & Achievement \\
\hline \multirow{2}{*}{$\begin{array}{l}\text { Improve the access of } \\
\text { population to rural } \\
\text { zones }\end{array}$} & $\begin{array}{l}\text { Specific and PGE } \\
\text { Length of earth roads repaired }(\mathrm{km})\end{array}$ & 482 & 1,500 & 977 \\
\hline & $\begin{array}{l}\text { intermediate } \\
\text { - length of rural and access roads }(\mathrm{km}) \\
\text { - length of rural trails - HIMO }(\mathrm{km}) \\
\text { - length of rice field tracks }(\mathrm{km}) \\
\text { - length of opening up roads } \\
\text { - length of FID repaired rural trails }\end{array}$ & & $\begin{array}{c}1,261 \\
24 \\
215 \\
130 \\
469 \\
\end{array}$ & $\begin{array}{c}829 \\
20 \\
52 \\
76 \\
403 \\
\end{array}$ \\
\hline \multirow{2}{*}{$\begin{array}{l}\text { Ensure the } \\
\text { practicability of } \\
\text { National Roads }\end{array}$} & $\begin{array}{l}\text { Specific and PGE } \\
\text { Length of national roads repaired }(\mathrm{km})\end{array}$ & 1,145 & 1,500 & 805 \\
\hline & $\begin{array}{l}\text { intermediate } \\
\text { - length of NR (national road) implemented, constructed and repaired } \\
\text { - length of bridges rehabilitated }(\mathrm{ml})\end{array}$ & & $\begin{array}{c}1,500 \\
638\end{array}$ & $\begin{array}{c}805 \\
1202\end{array}$ \\
\hline \multirow{3}{*}{$\begin{array}{l}\text { Maintain the whole } \\
\text { road network and the } \\
\text { good servicing } \\
\text { condition of the civil } \\
\text { engineering works }\end{array}$} & $\begin{array}{c}\text { Specific } \\
\text { - length of roads maintained }(\mathrm{km}) \\
\end{array}$ & 7,000 & 7,000 & 7000 \\
\hline & $\begin{array}{c}\text { intermediate } \\
\text { - length of the road network maintained }(\mathrm{km})\end{array}$ & 7,000 & 7,000 & 7200 \\
\hline & $\begin{array}{ll}\text { - National network maintained } & \end{array}$ & & minimum $4,000 \mathrm{~km}$ & 7200 \\
\hline
\end{tabular}


2005 PRSP Progress Report

\begin{tabular}{|c|c|c|c|c|}
\hline \multirow{2}{*}{ Specific objectives } & \multirow{2}{*}{ Indicators } & \multirow{2}{*}{2004} & \multicolumn{2}{|c|}{2005} \\
\hline & & & Objectives & Achievement \\
\hline \multirow{3}{*}{$\begin{array}{l}\text { Improve the } \\
\text { management, } \\
\text { productivity, and the } \\
\text { efficiency of the } \\
\text { transportation system }\end{array}$} & $\begin{array}{c}\text { Specific } \\
\text { - Progress rate of the transportation sector reform }\end{array}$ & $10 \%$ & $100 \%$ & $65 \%$ \\
\hline & $\begin{array}{l}\text { intermediate } \\
\text { - Progress rate of the establishment of autonomously managed ports } \\
\text { - Progress rate of the concession of non autonomous ports } \\
\text { - Have port compliance with ISPS standards }\end{array}$ & & $\begin{array}{l}4 \text { ports } \\
4 \text { ports } \\
6 \text { ports }\end{array}$ & $\begin{array}{l}50 \% \\
70 \% \\
70 \%\end{array}$ \\
\hline & $\begin{array}{l}\text { PGE } \\
\text { 1. Approval of the National Transportation Program (PNT) by the } \\
\text { Cabinet } \\
\text { Maritime-fluvial } \\
\text { Railways (southern and northern networks) } \\
\text { Air transportation } \\
\text { Maintenance of railroads } \\
\text { 2. Nedevelopment and repair } \\
\text { New structures set up for the port of Toamasina }\end{array}$ & & $\begin{array}{l}\text { Approved PNT } \\
-3 \text { ports } \\
-3 \text { site lighthouses } \\
\text { repaired } \\
-105 \mathrm{~km} \text { railroads } \\
-9 \text { bridges repaired } \\
3 \text { airports } \\
\text { SPAT established }\end{array}$ & 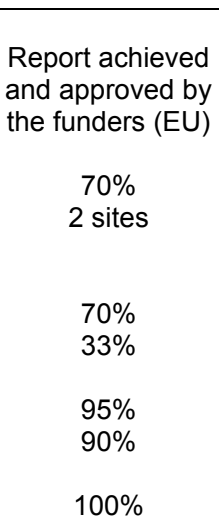 \\
\hline \multirow[t]{2}{*}{$\begin{array}{l}\text { Build national capacity } \\
\text { in meteorology }\end{array}$} & $\begin{array}{c}\text { Specific } \\
\text { Number of physical infrastructures repaired and modernized (\%) }\end{array}$ & $20 \%$ & $100 \%$ & $75 \%$ \\
\hline & $\begin{array}{l}\text { - weather stations repaired } \\
-\quad \text { Weather stations } \\
\text {-modernized weather stations } \\
\text { - Rainfall station } \\
\text { Agriculture and weather stations } \\
\text { - satellite systems set-up } \\
\text { - meteorological assistance (number of cultivation zones) }\end{array}$ & & $\begin{array}{c}09 \\
\\
100 \\
04 \\
\\
05 \\
02\end{array}$ & $\begin{array}{c}60 \% \\
\\
25 \% \\
75 \% \\
\\
100 \% \\
100 \%\end{array}$ \\
\hline
\end{tabular}

\subsection{Result Analysis}

The data related to the execution of the various 2005 PIP programs indicate overall significant improvement of the performance as regards the evolution of indicators.

In accordance with this evolution, in achievements related to rural tracks and national road rehabilitation, the balance sheet is mitigated (rural tracks $=805 \mathrm{Km} / 1,500 \mathrm{Km}$ ); national roads = $977 \mathrm{Km} / 1,500 \mathrm{Km}$ ). The decline in performance in 2005 may be attributed essentially to the weak performance of the Executive Secretariat of the Sector Transport Program in the management and the monitoring of the World Bank financed projects. This led to its cancellation before the planned end, and to resorting to an external firm for the administrative and fiduciary management of these projects.

One may conclude that the limited absorption capacity of the sector explains the poor performance in 2005. However additional specific reasons explain the low performance rate in achieving the two specific objectives, amongst others, the increase in the unit costs of works due to inflation. This rate is the more worrying as the forecasts had to be adjusted downward because of the regulation in public expenditures.

Conversely, net improvement is recorded in road maintenance performance: 7, $200 \mathrm{~km} / 7,000 \mathrm{~km}$ $(102 \%)$. It is useful to notice that the current maintenance involves the networks as a whole on an ongoing basis (annual programming), and integrates the needs related to engineering works. In keeping with the upgrading program, the networks eligible for maintenance will be reduced in future action plans.

The national meteorology, which is the core of the national system of management and prevention of natural disaster risks, contributes to reducing the negative impacts of the disasters mentioned above among the population in general, and the vulnerable layers, in particular. A fairly good performance in the sub sector is recorded, i.e. close to $75 \%$ in the rehabilitation and modernization of physical infrastructure due to the satellite systems and the meteorological assistance. On the other hand, it is worth underlining that, with a view to strengthening its capacity and to highlighting its contribution in developing the other sectors, of which transports and rural development, the principal activity realized was to set up the national precautious alert system for tsunami prevention. 


\subsubsection{Subprogram: Land Management}

The specific objectives of the subprogram consist of the following: (i) strengthening the management and the regulation of urban services, (ii) creating an environment of development enabling urban infrastructure and services, and (iii) securing the agglomerations.

\subsection{Evolution of Indicators}

Table 44: Indicators for Land Management

\begin{tabular}{|c|c|c|c|c|c|}
\hline \multirow{2}{*}{$\begin{array}{c}\text { Specific } \\
\text { objectives }\end{array}$} & \multirow{2}{*}{ Indicators } & \multirow{2}{*}{2004} & \multicolumn{2}{|c|}{2005} & \multirow{2}{*}{ Observations } \\
\hline & & & Objectives & Achievements & \\
\hline \multirow{5}{*}{$\begin{array}{l}\text { Strengthen } \\
\text { management } \\
\text { and } \\
\text { regulation of } \\
\text { urban services }\end{array}$} & $\begin{array}{l}\text { Specific } \\
\text { Satisfaction of the population as regards } \\
\text { the services provided }\end{array}$ & & $100 \%$ & $90 \%$ & \\
\hline & $\begin{array}{l}\text { Intermediate } \\
\text { 1. Master Town planning Programs \& } \\
\text { simplified town planning Programs } \\
\text { Operations conducted to reinforce } \\
\text { cooperation between communes } \\
\text { (intercommunalité) } \\
\text { Regions provided with Regional } \\
\text { Planning and Development Program } \\
\text { (SDAR) }\end{array}$ & & $\begin{array}{l}20 \text { plans validated } \\
2 \text { town planning } \\
\text { operations } \\
3\end{array}$ & $\begin{array}{c}10 \text { PDUi } \\
10 \text { PSU } \\
1 \text { bus shelter and one } \\
\text { sanitation plan } \\
0\end{array}$ & $\begin{array}{l}\text { SDAR postponed to } \\
2006\end{array}$ \\
\hline & $\begin{array}{l}\text { 2. letter of Policy } \\
\text { 3. Housing Policy }\end{array}$ & & $\begin{array}{l}\text { Technical unit set- } \\
\text { up } \\
\text { TORs of } \\
\text { consultants and } \\
\text { steering committee } \\
\text { Ditto }\end{array}$ & $\begin{array}{l}\text { Members appointed } \\
\text { TORs finalized } \\
\text { Ditto }\end{array}$ & \\
\hline & $\begin{array}{l}\text { 4. Town planning Law } \\
\text { 5. Master Plan for Sanitation (PDAV) of } \\
\text { town of Toliara }\end{array}$ & & $\begin{array}{l}\text { Validation } \\
\text { Town cleaned }\end{array}$ & $\begin{array}{l}\text { Law validated } \\
0\end{array}$ & $\begin{array}{l}\text { Official formalization in } \\
2006 \\
\text { Toliara PDAV } \\
\text { postponed to } 2006\end{array}$ \\
\hline & $\begin{array}{l}\text { PGE } \\
15 \text { regional development plans } \\
\text { approved }\end{array}$ & & Regions developed & $75 \%$ & \\
\hline \multirow{2}{*}{$\begin{array}{l}\text { Create an } \\
\text { urban } \\
\text { infrastructure } \\
\text { and services } \\
\text { environment } \\
\text { that enables } \\
\text { development }\end{array}$} & $\begin{array}{c}\text { Specific } \\
\text { Socioeconomic exchanges developed }\end{array}$ & & $100 \%$ & $80 \%$ & \\
\hline & $\begin{array}{l}\text { Intermediate } \\
\text { 6. Ambohimalaza bus station } \\
\text { 7. Madagascar's commune streets } \\
\text { 8. construction and/or repair of road } \\
\text { transportation terminal infrastructures } \\
\text { 9. creation of new towns } \\
\text { 10. provide and/or build equipment to } \\
\text { communes }\end{array}$ & & $\begin{array}{l}\text { The bus station } \\
\text { construction } \\
\text { program is } \\
\text { achieved } \\
\text { - } 205 \mathrm{KM} \text { of roads } \\
\text { and transportation } \\
\text { infrastructures } \\
\text { (urban ways, } \\
\text { streets, parking } \\
\text { lots, stairways...) } \\
\text { - } 24 \text { structuring } \\
\text { equipment (market, } \\
\text { commune office, } \\
\text { bus station...) } \\
\\
\text { - } 45 \text { assisting } \\
\text { equipment (WC, } \\
\text { shower booths, } \\
\text { garbage bins...) }\end{array}$ & $\begin{array}{l}\text { - } 45 \% \text { of initial } \\
\text { program } \\
-163, .83 \mathrm{Km} \text { of } \\
\text { tracks/ways } \\
\text { constructed and/or } \\
\text { repaired } \\
\text { - } 7 \text { markets repaired } \\
\text { and planned, } 3 \text { bus } \\
\text { stations constructed } \\
\text { and/or repaired, } 9 \\
\text { commune offices } \\
\text { - } 4 \text { WC/shower } \\
\text { booths, } 2 \text { tractors and } \\
4 \text { trailers, } 1 \\
\text { slaughterhouse, } 15 \\
\text { garbage bins, } 8 \text { green } \\
\text { parks, } 1 \text { technical unit } \\
\text { of TVM arranged, } \\
\text { "Analamanga gate" } \\
\text { arranged }\end{array}$ & \\
\hline \multirow[t]{2}{*}{$\begin{array}{l}\text { Secure } \\
\text { agglomerations }\end{array}$} & $\begin{array}{c}\text { Specific } \\
\text { On-site investment rate increased }\end{array}$ & & $100 \%$ & $85 \%$ & \\
\hline & $\begin{array}{l}\text { Intermediate } \\
\text { 11. Mandroseza lake protection project } \\
\text { 12. infrastructure repairs in the } \\
\text { peripheral communes of Antananarivo } \\
\text { (APIPA: authority for the protection of } \\
\text { Antananarivo plain against floods) }\end{array}$ & & $\begin{array}{l}\text { Mandroseza lake } \\
\text { protected } \\
\text { Secure the } \\
\text { agglomeration of } \\
\text { Antananarivo } \\
\text { against floods }\end{array}$ & $\begin{array}{l}\text { Environmental study } \\
\text { completed } \\
\qquad 80 \%\end{array}$ & \\
\hline
\end{tabular}




\subsection{Result Analysis}

The first specific objective is achieved at $90 \%$ due to the granting of the land planning tools to CTD, as well as the respect of the procedures in vigor, and to the action enabling inters communality promotion.

Socioeconomic exchanges developed due to resumption of urban, suburban, and rural dynamics by setting up collective social, cultural, and economic infrastructure equipments.

The Ambohimalaza station is built at $45 \%$ compared to the initial program due to inadequate financial amount, the planned program of activity on the development of

enabling urban infrastructure and services is achieved at $80 \%$.

For the security in agglomerations, the environmental study on the project of protecting the Lake of Mandroseza is achieved at $100 \%$, whereas APIPA focused on the rehabilitation of infrastructure in the peripheral communes of Antananarivo for preventing flood, which is achieved at $80 \%$.

The effort has to be sustained in protecting the Lake of Mandroseza, and it proves useful to focus means on securing the agglomeration of Antananarivo against flood.

\subsubsection{Subprogram: Energy}

The Policy of the government on the Energy Sector is helping directly the poor population by providing sustainable and good quality, at reasonable prices, the supply of energy that aims at creating a performing and efficient institutional framework for the assistance and support to the operators and investors in the sector.

The specific objectives set out in the energy subprogram consist in the following: (i) setting up an institutional and organizational reform to allow the development of the sector and create an enabling environment to investors, (ii) building capacity among the Electricity Regulation Office [Office de Régulation de l'Electricité (ORE)], and the Agency for Rural Electricity Development [Agence de Développement de l'Electricité Rural (ADER)], (iii) increasing the access to electricity in Madagascar, (iv) managing the energy and the environment in a rational manner, and ( $v$ ) providing end consumers and the country with a hydrocarbon supply system.

\subsection{Evolution of indicators}

Table 45: Indicators for Energy

\begin{tabular}{|c|c|c|c|c|}
\hline \multirow{2}{*}{ Specific objective } & \multirow{2}{*}{ Indicator } & \multirow{2}{*}{2004} & \multicolumn{2}{|c|}{2005} \\
\hline & & & Objectives & Achievements \\
\hline \multirow[t]{3}{*}{$\begin{array}{l}\text { Set up an institutional } \\
\text { and organizational } \\
\text { reform to develop the } \\
\text { sector and to create an } \\
\text { investment in favor of } \\
\text { the environment }\end{array}$} & $\begin{array}{l}\text { Specific } \\
\text { National Energy Program (PNE) } \\
\text { approved } \\
\text { Performance rate } \\
\text { - } \quad \text { Restructure JIRAMA } \\
\text { - } \quad \text { Implement the management } \\
\quad \text { contract }\end{array}$ & & $\begin{array}{l}100 \% \\
100 \% \\
100 \%\end{array}$ & $\begin{array}{l}\text { Under way } \\
100 \%\end{array}$ \\
\hline & $\begin{array}{l}\text { intermediate } \\
\text { PNE validated } \\
\text { JIRAMA restructured } \\
\text { Management contract implemented }\end{array}$ & & $\begin{array}{l}\text { Symposium organized } \\
\text { Recovery plan developed } \\
\text { Audit completed } \\
\text { MT/LT/ST investment plan } \\
\text { developed } \\
\text { Contract signed }\end{array}$ & $\begin{array}{l}100 \% \\
100 \% \\
100 \% \\
100 \% \\
100 \% \\
\end{array}$ \\
\hline & $\begin{array}{c}\text { PGE } \\
\text { Program approved by the Cabinet }\end{array}$ & & PNE & $75 \%$ \\
\hline \multirow{2}{*}{$\begin{array}{l}\text { Study on the price of in } \\
\text { accordance with the } \\
\text { provisions in the Law } \\
\text { and its decrees }\end{array}$} & tariffs applied & & $100 \%$ & $100 \%$ \\
\hline & $\begin{array}{l}\text { intermediate } \\
\text { Adjusted tariffs applied }\end{array}$ & & 2 & 2 \\
\hline \multirow[t]{2}{*}{$\begin{array}{l}\text { Capacity building } \\
\text { among ORE and ADER }\end{array}$} & $\begin{array}{c}\text { Specific } \\
\text { Number of promulgated texts }\end{array}$ & & 4 & 4 \\
\hline & $\begin{array}{l}\text { intermediate } \\
\text { Staff training } \\
\text { Web site implementation } \\
\text { Procedure manual } \\
\text { Texts/ fees }\end{array}$ & & $\begin{array}{c}3 \\
100 \% \\
100 \% \\
4\end{array}$ & $\begin{array}{c}2 \\
100 \% \\
100 \% \\
4\end{array}$ \\
\hline $\begin{array}{l}\text { Increase the access to } \\
\text { electricity in } \\
\text { Madagascar }\end{array}$ & $\begin{array}{l}\text { Specific } \\
\text { Electricity access rate }\end{array}$ & $23.92 \%$ & $100 \%$ & $25.31 \%$ \\
\hline
\end{tabular}




\begin{tabular}{|c|c|c|c|c|}
\hline \multirow{4}{*}{ Specific objective } & \multirow{2}{*}{ Indicator } & \multirow{2}{*}{2004} & \multicolumn{2}{|c|}{2005} \\
\hline & & & Objectives & Achievements \\
\hline & $\begin{array}{l}\text { intermediate } \\
\text { Number of villages provided with } \\
\text { electricity: } \\
\text { - by extending the network } \\
\text { - in decentralized mode } \\
\text { - photovoltaic system } \\
\text { Low cost expansion plan (PEMC) } \\
\text { Independent electricity production } \\
\text { (PIE) }\end{array}$ & & $\begin{array}{c}55 \\
45 \\
2 \\
100 \%\end{array}$ & $\begin{array}{c}08 \\
35 \\
2 \\
60 \% \\
15 \text { new ones inventoried } \\
26 \text { site studies }\end{array}$ \\
\hline & $\begin{array}{c}\text { PGE } \\
\text { Start a hydroelectric power plant }\end{array}$ & & $\begin{array}{c}\text { Equipping/construction } \\
\text { AHE of Sahanivotry } \\
\text { Hydroelectric }\end{array}$ & $20 \%$ \\
\hline \multirow[t]{3}{*}{$\begin{array}{l}\text { Rationally manage } \\
\text { energy and the } \\
\text { environment }\end{array}$} & \begin{tabular}{l}
\multicolumn{1}{c}{ Specific } \\
Number of economical stoves \\
distributed
\end{tabular} & $\begin{array}{l}\text { Non } \\
\text { available }\end{array}$ & 50,000 & 35,000 \\
\hline & Reforested area & & 1,100 ha & 820 ha \\
\hline & \begin{tabular}{l}
\multicolumn{1}{c}{ intermediate } \\
Substitution energy promoted \\
Saving fuel wood \\
Géloses (local secured management) \\
monitored
\end{tabular} & & $\begin{array}{c}2 \\
- \\
15\end{array}$ & $\begin{array}{c}\text { Negotiation with DGEF } \\
\text { under way } \\
7\end{array}$ \\
\hline \multirow[t]{2}{*}{$\begin{array}{l}\text { Provide to end } \\
\text { consumers and to the } \\
\text { country with a } \\
\text { hydrocarbon supply } \\
\text { system }\end{array}$} & $\begin{array}{l}\text { Specific } \\
\text { Installation rate in accordance with } \\
\text { the standards } \\
\text { Number of promulgated texts }\end{array}$ & & & \\
\hline & $\begin{array}{l}\text { intermediate } \\
\text { SNIH and RCEH set up } \\
\text { Product quality standardized } \\
\text { National supply secured } \\
\text { Monitoring of the prices of petroleum } \\
\text { product }\end{array}$ & & $\begin{array}{c}\text { Lab } \\
\text { Workshop } \\
\text { Monitoring } \\
\text { Prices defined and } \\
\text { monitoring of evolution }\end{array}$ & $\begin{array}{l}\text { Under way } \\
\qquad \begin{array}{c}100 \% \\
100 \% \\
\text { Under way }\end{array} \\
\text { Under way }\end{array}$ \\
\hline
\end{tabular}

SNIH: National Hydrocarbon Information System

RCEH: Central Register for Hydrocarbon Operating

\subsection{Result Analysis}

The effort has to be sustained regarding the officialization of the PNE (Program National de l'Energie) (National Energy Program). The various actions that were undertaken to allow the development of the sector are defined in a relevant manner in keeping with the implementation of PRSP, in order to contribute, in particular, to the setting up of the institutional and organizational reform and, in general, to finalize the PNE. In addition the above mentioned PNE was validated during the Energy Symposium that was held in October and November 2005. So, all this should facilitate its approval at the Cabinet level.

As regards tariffs fixation, two adjustments were operated, i.e. a $10 \%$ increase in July 2005 , and another 35\% one in November 2005.

The electrification work is achieved in overall at $25 \%$. This is a poor performance compared to the objectives because the action plan on electrification of the villages, which is a network system, should be improved, and the decentralized mode system requires a particular effort to exceed the number of households connected to electricity for 2006. The intermediacy of higher authorities is desirable to resolve the issues in customs clearance of electric material and equipment raised by the department, but that seems to persist, engendering the delay in the execution of projects on network extension and rural electrification.

Capacity building among ADER (Agence de Développement de l'Electricité Rurale) and the finalization of the company regulations and the manual of procedures among ORE (Office de Régulation de l'Electricité) will certainly allow the expediting of the implementation of the electrification program, especially in rural communes. The same applies to the progress of work for developing the Sahanivotry hydroelectric power plant, the object of the PGE 2005 indicator, of which the execution percentage was only about $20 \%$, which stands for earthworks, access road building and construction of works for intake of water.

Finally, the effective implementation of the SINH and the RCEH, as well as the MEM website and intranet, have to be set up rapidly to really contribute to the development of the Hydrocarbon sub sector. 


\subsubsection{Subprogram: Post, Telecommunication and Communication}

It is important to remind that the specific objectives planned in keeping with the PRSP for the sector consist in: (i) Developing the postal sector services, (ii) Promoting the ICT for all, (iii) Developing the National Telecommunication Backbone, (iv) Ensuring International Connection through optic fibers, (v) setting up Technical poles (techno poles) in partnership with the private sector, (vi) Promoting and guaranteeing the access to information for all and the free expression in media, (vii) Promoting the development of multimedia services and ICT, and (viii) Ensure an active communication for the social progress and the economic development.

\subsection{Evolution of Indicators}

Table 46: Indicators for Post, Telecommunication and Communication

\begin{tabular}{|c|c|c|c|c|}
\hline \multirow{2}{*}{ Specific objective } & \multirow{2}{*}{ Indicator } & \multirow{2}{*}{2004} & \multicolumn{2}{|r|}{2005} \\
\hline & & & Objectives & Achievements \\
\hline \multirow[t]{2}{*}{$\begin{array}{l}\text { POSTES } \\
\text { Develop postal sector } \\
\text { services }\end{array}$} & \begin{tabular}{l}
\multicolumn{1}{c}{ Specific } \\
Develop postal \\
financial services
\end{tabular} & & Services developed & Obvious improvement \\
\hline & $\begin{array}{l}\text { intermediate } \\
\text { Postal financial } \\
\text { services developed } \\
\text { CCP product } \\
\text { developed } \\
\text { Number of } \\
\text { "Tsinjolavitra" savers } \\
\text { increased } \\
\text { "Tsinjoavotra" saving } \\
\text { system created } \\
\text { Financial } \\
\text { establishment set up }\end{array}$ & 60,000 & $\begin{array}{l}\text { MAERI product } \\
\text { started (express } \\
\text { international postal } \\
\text { order) } \\
\text { Good quality of } \\
\text { products and services } \\
120,000 \\
\text { Stabilize the assets } \\
\text { Change the status of } \\
\text { CCP }\end{array}$ & $\begin{array}{l}\text { France Madagascar and } \\
\text { Madagascar Djibouti relationships } \\
\text { (Import-Export) } \\
\text { Improve the quality of existing } \\
\text { services and products } \\
105,000 \\
\text { Studies under way } \\
\text { Studies conducted with the } \\
\text { Treasury and other institutions } \\
\text { under way }\end{array}$ \\
\hline \multirow[t]{3}{*}{$\begin{array}{l}\text { TELECOMMUNICATION } \\
\text { Promote ICT for all }\end{array}$} & $\begin{array}{r}\text { Specific } \\
\text { ICT access rate }\end{array}$ & $\begin{array}{l}6 \text { "remote centers" set } \\
\text { up from HIPC funds } \\
\text { (Maevatanàna, Betafo, } \\
\text { Iharana, Andilamena, } \\
\text { Ikongo, Morafenobe) } \\
3 \text { remote centers set-up } \\
\text { with Telma funds (Fort } \\
\text { Dauphin, Ambilobe, } \\
\text { Maintirano) }\end{array}$ & 16 remote centers & $\begin{array}{l}\text { - Clarifying the } 2005 \text { remote } \\
\text { centers files with Telma and DTS } \\
\text { - Acquisition of computers to equip } \\
\text { the } 16 \text { remote centers } \\
\text { - Create and provide equipment } \\
\text { the production center to feed } \\
\text { remote centers }\end{array}$ \\
\hline & \begin{tabular}{l}
\multicolumn{1}{c}{ Intermediate } \\
Prospecting \\
partnership among \\
private sector
\end{tabular} & $\begin{array}{l}\text { Identification of } 6 \text { private } \\
\text { operators to manage the } \\
\text { HIPC funded remote } \\
\text { centers }\end{array}$ & $\begin{array}{l}\text { Mobilize the private } \\
\text { sector to create } \\
\text { remote centers }\end{array}$ & $\begin{array}{l}\text { CT Initiative for Coordination } \\
\text { Committee (CCITIC) created }\end{array}$ \\
\hline & \begin{tabular}{l}
\multicolumn{1}{c}{ PGE } \\
Cost of local \\
communication \\
reduced
\end{tabular} & 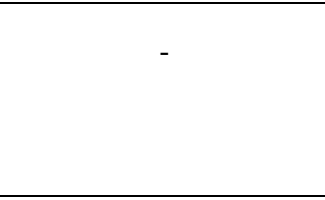 & $\begin{array}{l}30 \text { to } 50 \% \text { reduction in } \\
\text { costs of } \\
\text { communications } \\
\text { between different } \\
\text { telecom companies }\end{array}$ & $100 \%$ \\
\hline \multirow[t]{2}{*}{$\begin{array}{l}\text { Develop the National } \\
\text { Telecommunication } \\
\text { Backbone }\end{array}$} & \begin{tabular}{l}
\multicolumn{1}{c}{ Specific } \\
National Optic Fiber \\
Backbone set up
\end{tabular} & $\begin{array}{l}\text { - Development of the } \\
\text { national backbone } \\
\text { skeleton with the } \\
\text { participation of private } \\
\text { sector, civil society, the } \\
\text { administration } \\
\text { technicians and donors }\end{array}$ & $\begin{array}{l}\text { Deployment of a } \\
\text { VSAT network to } \\
\text { complement the } \\
\text { National optic fiber } \\
\text { backbone }\end{array}$ & $\begin{array}{l}\text { - strengthen the national } \\
\text { communication infrastructure } \\
\text { - the call for bids started by Telma } \\
\text { on the three main axes to be } \\
\text { linked by the optic fiber: Toliara } \\
\text { Antananarivo; Toamasina } \\
\text { Antananarivo; Antananarivo } \\
\text { Mahajanga }\end{array}$ \\
\hline & $\begin{array}{l}\quad \text { Intermediate } \\
\text { Implement connectivity } \\
\text { program for the rural } \\
\text { area }\end{array}$ & $\begin{array}{l}\text { - Organization of a } \\
\text { workshop to present the } \\
\text { study on the national } \\
\text { backbone } \\
\text { - create a task force for } \\
\text { the progress of the } \\
\text { underwater optic fiber }\end{array}$ & $\begin{array}{l}\text { - rural zone } \\
\text { connectivity }\end{array}$ & $\begin{array}{l}\text { - first phase of the study on the } \\
\text { improvement of access to ICT in } \\
\text { rural areas with the World Bank, } \\
\text { achieved at } 100 \% \\
\text { - Mission of Sensitizations in the } \\
\text { three pilot zones (Vakinankaratra, } \\
\text { Boeny, Anosy) complete } \\
\text { - The "Internet Bus" project started }\end{array}$ \\
\hline
\end{tabular}


2005 PRSP Progress Report

\begin{tabular}{|c|c|c|c|c|}
\hline \multirow{6}{*}{ Specific objective } & \multirow{2}{*}{ Indicator } & \multirow{2}{*}{2004} & \multicolumn{2}{|r|}{2005} \\
\hline & & & Objectives & Achievements \\
\hline & & $\begin{array}{l}\text { and the national } \\
\text { backbone projects }\end{array}$ & & with DTS at $100 \%$ \\
\hline & $\begin{array}{l}\text { ICT set up in the } \\
\text { Administration in the } \\
\text { area of E-governance }\end{array}$ & $\begin{array}{l}\text { - undertake preliminary } \\
\text { studies in relation with } \\
\text { E-governance } \\
\text { - Interconnection Project } \\
\text { of MTPC central } \\
\text { Directorates }\end{array}$ & $\begin{array}{l}\text { - Inter-institutional } \\
\text { coordination } \\
\text { - inter connection of } \\
\text { central directorates }\end{array}$ & $\begin{array}{l}\text { - Start up of "the Government } \\
\text { Intranet" pilot site at MTPC: } \\
\text { * training on intranet with Microsoft } \\
\text { for the } 3 \text { MTPC technicians } \\
\text { completed } \\
\text { * training of senior civil servants in } \\
\text { using the intranet completed } \\
\text { - technical support to the Prime } \\
\text { Minister's Office for the } \\
\text { government Intranet project } \\
\text { - participation and support to the } \\
\text { CDEG for the implementation of } \\
\text { the PNEG } \\
\text { - The document "strategic } \\
\text { planning guide for regions" } \\
\text { developed }\end{array}$ \\
\hline & $\begin{array}{l}\text { Implementation of the } \\
\text { optic fiber networking } \\
\text { and/or wireless in the } \\
\text { agglomerations }\end{array}$ & & $\begin{array}{l}\text { - prioritize the choice } \\
\text { for axes to be linked } \\
\text { by the optic fiber to be } \\
\text { deployed }\end{array}$ & $\begin{array}{l}\text { - set up and functioning of the } \\
\text { Telma privatization monitoring } \\
\text { committee (MTPC, OMERT, } \\
\text { DOP/FINANCE, STP/FINANCE, } \\
\text { TELMA) } \\
\text { - } 2005 \text { deployment program } \\
\text { regarding the optic fiber backbone } \\
\text { and VSAT with Telma and Gulfsat }\end{array}$ \\
\hline & $\begin{array}{l}\text { PGE } \\
\text { Start up of private } \\
\text { project }\end{array}$ & - & $\begin{array}{l}\text { Set up the optic fiber } \\
\text { for the national } \\
\text { backbone }\end{array}$ & ( \\
\hline $\begin{array}{l}\text { Ensure international } \\
\text { Connection through optic } \\
\text { fibers }\end{array}$ & 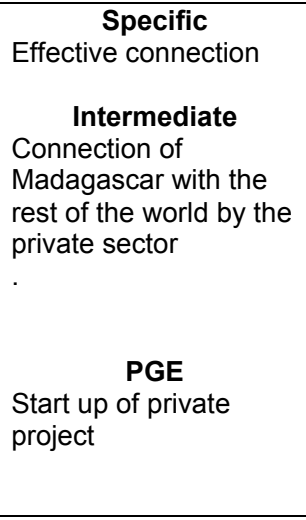 & $\begin{array}{l}\text { - undertake the } \\
\text { feasibility studies of the } \\
\text { connectivity of } \\
\text { Madagascar (through } \\
\text { Tulear) by means of } \\
\text { underwater optic fiber } \\
\text { with the rest of the world } \\
\text { (Via Mtunzini DURBAN } \\
\text { South Africa) and } \\
\text { finalize the technical } \\
\text { studies }\end{array}$ & $\begin{array}{l}\text { Integration of } \\
\text { Madagascar into the } \\
\text { EASSY optic fiber } \\
\text { connection project in } \\
\text { the Mozambique } \\
\text { Channel riverside } \\
\text { countries } \\
\text { Set optic fiber for } \\
\text { international } \\
\text { connectivity }\end{array}$ & $\begin{array}{l}\text { - signing the MOU by Telma in the } \\
\text { EASSY Consortium } \\
\text { - Development of the } \\
\text { Antananarivo broadband optic } \\
\text { fiber network }\end{array}$ \\
\hline \multirow[t]{2}{*}{$\begin{array}{l}\text { Set up technical poles in } \\
\text { partnership with the } \\
\text { private sector }\end{array}$} & \begin{tabular}{l}
\multicolumn{1}{c}{ Specific } \\
- setup of a techno \\
pole in Antanetibe \\
Ivato
\end{tabular} & $\begin{array}{l}\text { Coordination with the } \\
\text { Vice Prime Minister's } \\
\text { Office to start the } \\
\text { feasibility of techno } \\
\text { poles }\end{array}$ & Set up techno pole & - pre feasibility study completed \\
\hline & \begin{tabular}{l}
\multicolumn{1}{c}{ Intermediate } \\
Number of contracts of \\
partnership
\end{tabular} & & & $\begin{array}{l}\text { - techno pole files in collaboration } \\
\text { with the Bank and PPIC projects } \\
\text { prepared } \\
\text { - files presented to PIC }\end{array}$ \\
\hline OMERT Restructuring & \begin{tabular}{l}
\multicolumn{1}{c}{ PGE } \\
New organization and \\
Board of Directors \\
established
\end{tabular} & & $\begin{array}{l}\text { - set up new ARTEC } \\
\text { regulator ARTEC to } \\
\text { replace OMERT }\end{array}$ & $90 \%$ \\
\hline $\begin{array}{l}\text { Develop the National } \\
\text { Telecommunication } \\
\text { Program (PNT) }\end{array}$ & $\begin{array}{l}\text { PGE } \\
\text { The Cabinet approves } \\
\text { the program }\end{array}$ & $\begin{array}{l}\text { Develop the national } \\
\text { telecommunication } \\
\text { policy }\end{array}$ & $\begin{array}{l}\text { - validate PNT } \\
\text { - promulgate the laws } \\
\text { on } \\
\text { telecommunications } \\
\text { and ICTs }\end{array}$ & $100 \%$ \\
\hline
\end{tabular}




\begin{tabular}{|c|c|c|c|c|}
\hline \multirow{2}{*}{ Specific objectives } & \multirow{2}{*}{ Indicators } & \multirow{2}{*}{2004} & \multicolumn{2}{|c|}{2005} \\
\hline & & & Objectives & Achievements \\
\hline $\begin{array}{l}\text { COMMUNICATION } \\
\text { Promote and } \\
\text { guarantee the } \\
\text { access to information } \\
\text { for all and the } \\
\text { freedom of } \\
\text { expression in media }\end{array}$ & $\begin{array}{l}\text { Extension of information - } \\
\text { communication (DIRM) } \\
\\
\text { Improvement of Production } \\
\text { quality } \\
\text { Several productions by TVM } \\
\text { producers are selected and } \\
\text { awarded a prize in public } \\
\text { service Radio and Television } \\
\text { at international level } \\
\text { (ORTM) } \\
\text {-Rehabilitation of an } \\
\text { "animation" center and } \\
\text { strengthen the national } \\
\text { capacity building in } \\
\text { communication and on } \\
\text { facilitation of activity } \\
\text { (DAC) }\end{array}$ & $\begin{array}{l}\text { - Construction of technical } \\
\text { and administrative building } \\
(R+5) \\
\text { - repair technical buildings } \\
\text { and housing for technician } \\
\text { - masts construction } \\
\text { - provide audiovisual and } \\
\text { computer equipments } \\
\\
\text { - communication mode } \\
\text { survey in } 13 \text { districts of } \\
\text { Madagascar } \\
\text { - develop IEC materials and } \\
\text { support the implementation } \\
\text { of the EKA program } \\
\text { - sensitize the media in } \\
\text { HIAKA } 2004 \text { campaign } \\
\text { - Train community } \\
\text { mobilization agents } \\
\text { Madagascar by CFI } \\
\text { - } 7 \text { producers trained in } \\
\text { Africa } \\
\text { - repair head offices } \\
\end{array}$ & $\begin{array}{l}\text { Construction of the } \\
\text { audiovisual complex in } \\
\text { Anosy } \\
\text { Acquire technical } \\
\text { equipment and } \\
\text { computers } \\
\text { Improve the sound and } \\
\text { picture quality of RNM } \\
\text { and TVM } \\
\text { - construction and } \\
\text { repairing of technical } \\
\text { infrastructures } \\
\text { Documents distributed } \\
\text { Production of materials } \\
\text { of good quality } \\
\text { Improve the working } \\
\text { framework } \\
\text { lraining workshop on } \\
\text { communication and } \\
\text { mobilization techniques } \\
\text { the reports on RNM and } \\
\text { Imprograms } \\
\text { leading to behavior } \\
\text { Knowledge of themes } \\
\text { live of }\end{array}$ & $\begin{array}{l}100 \% \\
100 \% \\
\text { Acquire various equipment } \\
\text { (BLU, Camera, etc) } \\
\text { Technical blocks of } \\
\text { Vohemar, Anstiranana, } \\
\text { Ambanja, Abatondrazaka, } \\
\text { Arivonimamo } \\
100 \% \\
100 \%\end{array}$ \\
\hline $\begin{array}{l}\text { Promote the } \\
\text { development of } \\
\text { multimedia and ICT } \\
\text { services }\end{array}$ & $\begin{array}{c}\text { Specific } \\
\text { Satisfaction of the population }\end{array}$ & & $\begin{array}{l}\text { Improve program } \\
\text { schedules } \\
\text { Shooting a Malagasy } \\
\text { miniseries }\end{array}$ & \\
\hline $\begin{array}{l}\text { Ensure an active } \\
\text { communication for } \\
\text { the social progress } \\
\text { and economic } \\
\text { development }\end{array}$ & \begin{tabular}{l}
\multicolumn{1}{c}{ Specific } \\
Support the promotion of \\
democracy \\
Setup and provision of new \\
equipment to regions
\end{tabular} & $\begin{array}{l}\text { - training of media journalists } \\
\text { in the provinces: Tulear, } \\
\text { Fianarantsoa, Toamasina } \\
\text { - deliver professional IDs for } \\
\text { journalists ( } 2004-2007) \\
\text { and finalize the project-draft } \\
\text { of the communication code } \\
\text { - RNM and TVM coverage } \\
\text { - identify the satellite } \\
\text { providers and prospect } \\
\text { funding }\end{array}$ & $\begin{array}{l}\text { Build capacities in } \\
\text { communication } \\
\text {. Improve the quality of } \\
\text { productions and } \\
\text { programs in all the } \\
\text { regions } \\
\text { Gather the technical } \\
\text { parameters for the } \\
\text { installation of equipment } \\
\text { in the regions }\end{array}$ & $\begin{array}{l}50 \% \text { of the technicians } \\
\text { from the } 22 \text { regions } \\
\text { Development and cleaning } \\
\text { of the audiovisual sector } \\
80 \% \\
\text { Provide digital production } \\
\text { equipment: } \\
\text {. Digital cameras: } 22 \\
\text {. Editing computers: } 22 \\
\text {. Digital recorders } \\
\text {. Studio equipment: } 22\end{array}$ \\
\hline
\end{tabular}




\begin{tabular}{|c|c|c|c|c|}
\hline \multirow{2}{*}{ Specific objectives } & \multirow{2}{*}{ Indicators } & \multirow{2}{*}{2004} & \multicolumn{2}{|c|}{2005} \\
\hline & & & Objectives & Achievements \\
\hline & $\begin{array}{l}\text { Improve the receiving quality } \\
\text { Increase revenues from ads }\end{array}$ & $\begin{array}{l}\text { Improve the ORTM turnover } \\
\text { MGF } 2,339,624,213\end{array}$ & $\begin{array}{l}\text { Train agents in } \\
\text { marketing }\end{array}$ & $\begin{array}{l}\text { Edit the project document } \\
\text { for signing the contract: } \\
\text { EUTELSAT } \\
\text { Increase revenues from } \\
\text { ads }\end{array}$ \\
\hline
\end{tabular}

\subsection{Result Analysis}

The results obtained from the development of postal financial services are satisfactory due to relevant actions such as the personnel capacity building, the use of new management tools, and the application of the professional code of ethics.

The working of international IPS and IFS/IMO centers allowed for securing the international parcel delivery service market, on the one hand, and that of postal packages and parcels, on the other hand Regarding the postal Sorting Center, the relocation was done and the outsourcing and the layout of various service compartments in accordance with the international standards, contributed to the improvement of the mail processing.

Compared with the objective set in the 2005-2007 Business Plan on the installation of the sixteen (16) Remote centers per year, the work is still on mid-way, due to the delay in the purchase of computer materials required for their installation.

The deploying of a VSAT network with Telma and Gulfsat was necessary to complement the national Optic Fiber backbone. Thus, the national communication infrastructure is reinforced on the one hand, but on the other hand, a bidding process for the optic fiber connection of the 3 main axes started, i.e. Toliara-Antananarivo, Antananarivo-Toamasina and Antananarivo-Mahajanga. Thereafter the setting up the national Optic Fiber Backbone was able to start together effectively with the work by the Taskforce (Telma-MTPC).

Due to the synergy among the various entities in the Ministry: Ministry-Paositra-DTS-RNM/TVM, the first phase of the study for improving access to ICT in rural areas with the World Bank is achieved at $100 \%$., the mission of sensitization in three (03) pilot regions (Vakinakaratra, Boeny, Anosy) is also completed, as well as the "Internet Bus" Project that was started with DTS and achieved at $100 \%$.

Regarding ICT setup in the Administration in the framework of E-governance, the results obtained are satisfactory due to the material and technical support to the government institutions in establishing their websites.

The action for extending and modernizing the radio television in regions is still weak due to the delay in funds disbursement. The equipment endowment and the modernization of the national radio station and the national TV station is achieved at $85 \%$.

\subsubsection{Program 10. Opening to the Global Competition}

The overall objective of the Program Opening to Global Competition is to develop international and regional relations for a larger opening on the economic, cultural, and social levels. The 2 subprograms, i.e. Trade and Foreign Affairs are concurring to the achievement of this objective.

\subsubsection{Subprogram: international Relations}

In international relations, two objectives are targeted: (i) Improve the communication with embassies, ministries, and other entities, professionalize the staff of the MAE; and (ii) strengthen Madagascar's participation in bilateral, regional, and multilateral system.

The actions undertaken were focused towards developing the international relations for strengthening economic, cultural, and social partnership, and intensifying external exchanges to the benefit of a broadened social base and the strengthening of Madagascar's presence all over the world, and strengthening Madagascar's participation in the regional cooperation system, and strengthening Madagascar's regional integration. 


\subsection{Indicators table}

Table 47: Indicators for international Relations

\begin{tabular}{|c|c|c|c|}
\hline \multirow[b]{2}{*}{ Indicators } & \multirow[b]{2}{*}{2004} & \multicolumn{2}{|r|}{2005} \\
\hline & & \begin{tabular}{|c|} 
Objectives \\
(provisional)
\end{tabular} & Achievements \\
\hline \multicolumn{4}{|l|}{ Intermediate indicators } \\
\hline Number of signed conventions & 27 & 21 & 23 \\
\hline Number of ratifications & 16 & 13 & 09 \\
\hline Number of economic, commercial, cultural partnerships & 01 & 02 & 02 \\
\hline \multicolumn{4}{|l|}{ Number of accreditations } \\
\hline From Madagascar to foreign countries & 01 & 01 & 01 \\
\hline From foreign countries to Madagascar & 04 & 02 & 04 \\
\hline \multicolumn{4}{|l|}{ Presentation of credentials } \\
\hline By Madagascar & 39 & 11 & 02 \\
\hline By foreigners & 12 & 31 & 15 \\
\hline \multicolumn{4}{|l|}{ Embassy opening } \\
\hline Madagascar's embassies abroad & 02 & 01 & 02 \\
\hline Foreign embassies in Madagascar & 01 & 01 & 01 \\
\hline Number of trained and retrained staff members & & 52 & 97 \\
\hline \multicolumn{4}{|l|}{ PGE indicators } \\
\hline Number of investors sent per embassy & & 3 investors & 22 missions; 13 investors \\
\hline Number of projects sent per representation & & 3 projects & 114 projects of which (67 Projects by the \\
\hline & & & $\begin{array}{l}\text { bilateral co operations and } 47 \text { Projects } \\
\text { multilateral co operations) }\end{array}$ \\
\hline Number of projects sent per organization & & 1 project & 12 projects \\
\hline
\end{tabular}

\subsection{Result Analysis}

As regards the development of international relations, the main achievements relate to the diplomatic, economic, and commercial relations of Madagascar that was materialized in 2005 through the opening of two (02) Malagasy embassies abroad (Bern, and Libya); the presentation of fifteen (15) credentials by foreigners to the country; the establishment of two (02) economic, commercial, and cultural partnerships; the signing of various agreements; and participation in International Fairs.

Concerning conventions, the 2005 forecasts were exceeded despite a decline in the order of $15 \%$, in the number of signed conventions compared with 2004. However, the number of ratification also fell by $31 \%$ compared to the forecasts.

Regarding the intensification of external exchanges and the strengthening of international presence of Madagascar the year 2005 was marked by the cancellation of a large part of its foreign debt following the completion point in October 2004 in keeping with the HIPC Initiative; visits by high level figures in Madagascar; the Ministerial Conference of Francophone, and the $3^{\text {rd }}$ IOC Heads of States Summit in Antananarivo.

Concerning the strengthening of the participation of Madagascar in the regional cooperation system, and the strengthening of the regional integration of Madagascar, achievements were recorded in a renovated cooperation frameworks with $\mathrm{IOC}$, the elaboration of the national paper and the participation in the meeting of the SADC Council of Ministers, the meeting with the European Commissioner regarding ACP-UE development and humanitarian aid, and Madagascar full fledged membership to COMESA.

Regarding the professionalizing of MAE staff, 97 people out of 52 intended one were trained and retrained, i.e. an achievement rate of about $187 \%$.

In keeping with the General Policy of the Government [Politique Générale de I'Etat (PGE)], the ministry of foreign affairs had specific assignments: (i) orienting bilateral representations towards economic and commercial actions; (ii) materializing bilateral and multilateral cooperation, and (iii) optimizing the participation in regional organizations.

All objectives set for 2005 were achieved. 22 missions and 13 investors were sent by bilateral representations; 114 projects (of which 67 , bilateral cooperation projects and 47 multilateral projects) and 12 projects were undertaken, respectively by regional cooperation and organizations. These results were obtained due to various economic missions; the participation in international fairs and exhibitions, the strengthening of economic and commercial relations, the capacity building, the actions of promotion, and the participation in international and regional sessions and meetings. 


\subsubsection{Subprogram: Trade}

\subsection{Indicators table}

The specific objective set for the Subprogram Trade is to make profitable our membership to various international organizations and groupings by seizing the opportunities for developing our export.

Table 48: Indicators for Trade

\begin{tabular}{|c|c|c|c|c|}
\hline Specific objectives & Indicators & $\begin{array}{c}2004 \\
\text { Achievements }\end{array}$ & $\begin{array}{c}2005 \\
\text { Objectives }\end{array}$ & $\begin{array}{c}2005 \\
\text { Achievements }\end{array}$ \\
\hline \multirow{3}{*}{$\begin{array}{l}\text { Make profit on our membership to } \\
\text { different organizations and } \\
\text { international groupings by seizing the } \\
\text { available opportunities to develop our } \\
\text { exportations }\end{array}$} & Export values (in SDR Millions) & 669.11 & 802.93 & 571.66 \\
\hline & Export / GDP & 29.1 & 39.6 & 28.2 \\
\hline & $\begin{array}{l}\text { Exports of textile products (in } \\
\text { SDR Millions) }\end{array}$ & 294 & - & 210 \\
\hline
\end{tabular}

\subsection{Result Analysis: actions and activity/ result Indicators; specific and sectors/ objectives}

Between 2003 and 2004, export value increased by 10\%, and declined 15\% between 2004 and 2005. The export value target was reached only at $71 \%$; the gap is especially due to the decrease in export revenues for some products such as vanilla and textile products, that decreased by close to $28 \%$.

The ratio Export to GDP didn't nearly changed.

The main constraints originated from the misunderstanding, the non application of the current texts by the actors involved, form delay of the collection of information to develop the trade newsletter, and to the non effective connectivity of the website on external trade; the challenges therefore consist in the following:

- Planning the development of the materials for extending the texts (capacity building, radio program production, brochures, posters,...) and/or the intensification of the sensitization missions while setting up an inter ministry partnership system;

- Boosting the trade information system.

\subsubsection{Performances of large projects}

The PNUD /DAP 1 Project and FNUAP supported the implementation of a national monitoring evaluation system. The CREAM conducted various economic (the IG2P, the regional integration, the investment climate in Madagascar, the depreciation of exchange rate,, the impact of oil price increase). The PDSP2 Program contributed to the increase in tourist numbers and capacity infrastructures, and the facilitation of procedure of investment. The activities led by PSDR related on project financing. The main achievements of the PGRM are related to geophysical survey work. In the area of environment, the EPIII indicated satisfactory results regarding the environment mainstreaming and the increased surface of protected areas; but the performance is poor compared to the objectives. The following projects and programs: the National Program for Road Maintenance (PNER/UE), the National Program for Engineering Works Maintenance (PNOEA/UE), the Project on Cyclone Damage /UE/BADEA/BAD, the Project for rehabilitating the RN6 between Ambondromamy Bekoratsaka/BAD, the Sectoral Transportation Project (PST/PTR/PIIT/BM), the Urban Infrastructure Project II/BM, Road Maintenance Funds (FER/multi donors), the projects financed by HIPC, Japan, USAID, and AFD implemented in this sector indicated satisfactory performance, especially the projects financed by ADB Group. Project II for Development of The Energy Sector contributed largely in the electrification of rural and suburban areas, and in the implementing reforms within JIRAMA. The Project ICT for All contributed to improving the access rate to telecommunication services. USAID, through the Program for Broadened Critical Markets, allowed increasing export among 29 companies which adopt Business Best Practices.

The PDSP 2, due to promotion and marketing activities, the set up of the capacity infrastructure and studies on the regulatory framework (Investment Charter) and to trade representations that were set up (Business Brokers), contributed to promoting private investment especially through the basic structures that were set up. 


\subsection{SOCIAL ASPECTS}

\subsubsection{Program 11. DeVelopment of educational leVel of the Population and the Research}

The overall objective of the program is to universalize the Fundamental Education and to improve its quality and relevance so that it responds to the socioeconomic needs of the country.

The three Subprograms that were implemented relate to the following:

- Fundamental Education,

- Post - Fundamental Education,

- Research

\subsubsection{Subprogram: Fundamental Education}

The specific objectives set are the following: (i) to plan and to manage reforms in keeping with the Fundamental Education (ii) to improve the quality and efficiency of Fundamental Education (iii) to ensure the equity and access to Fundamental Education, (iv) to improve the management and accountability at central level of Ministry in charge of Education, including the budget and cost management.

\subsection{Indicators table}

Table 49: Indicators for Fundamental Education

\begin{tabular}{|c|c|c|c|c|}
\hline \multirow{2}{*}{ Specific objectives } & \multirow{2}{*}{ Indicators } & \multirow{2}{*}{2004} & \multicolumn{2}{|c|}{2005 * } \\
\hline & & & Objectives & Achievement \\
\hline $\begin{array}{l}\text { To plan and manage } \\
\text { the reform in the area } \\
\text { of Fundamental } \\
\text { Education }\end{array}$ & $\begin{array}{l}\text { Specific indicators } \\
\text { Education for All Paper updated and validated } \\
\text { PGE } \\
\text { The cabinet approves the EFA program }\end{array}$ & & $\begin{array}{l}\text { The EFA } \\
\text { document is } \\
\text { developed and } \\
\text { validated }\end{array}$ & $\begin{array}{l}\text { Document achieved } \\
\text { and validated } \\
\text { achieved }\end{array}$ \\
\hline $\begin{array}{l}\text { To improve the quality } \\
\text { and efficiency of } \\
\text { Fundamental } \\
\text { Education }\end{array}$ & $\begin{array}{l}\text { Completion rate } \\
\text { Overall repetition rate } \\
\text { Urban } \\
\text { Rural } \\
\text { Number of textbooks distributed } \\
\text { Recruitment of new teachers } \\
\text { The ratio pupil/teacher in all primary schools } \\
\text { Urban } \\
\text { Rural }\end{array}$ & $\begin{array}{l}47 \\
29.9 \\
17.9 \\
31.0 \\
\\
56 \\
49 \\
56\end{array}$ & $\begin{array}{l}53 \\
19 \\
11 \\
27 \\
1,139,966 \\
2,000 \\
56 \\
49 \\
58\end{array}$ & $\begin{array}{l}60 \\
18,2 \% \\
13,4 \% \\
18,7 \% \\
1,041,700 \\
1900 \\
60(52-2005 / 2006) \\
48 \\
60\end{array}$ \\
\hline $\begin{array}{l}\text { Ensure the equity } \\
\text { and access to } \\
\text { Fundamental } \\
\text { Education }\end{array}$ & $\begin{array}{l}\text { Specific indicators } \\
\% \text { of } 6 \text { years old children attending school in the first } \\
\text { cycle of fundamental education } \\
\text { Number of kits distributed } \\
\qquad \text { PGE specific indicators } \\
\text { Net Enrolment rate } \\
\text { Number of classrooms built (Public Primary schools) }\end{array}$ & 97 & $\begin{array}{l}94 \\
\text { pupils } \\
1,200,000 \\
\text { Teachers } \\
2000 \\
86 \\
2,000\end{array}$ & $\begin{array}{l}94 \\
1,200,030 \\
1900 \\
98 \\
1,423(69,4 \%)\end{array}$ \\
\hline $\begin{array}{l}\text { To improve the } \\
\text { management and } \\
\text { accountability at } \\
\text { central level of the } \\
\text { Ministry of Education, } \\
\text { including budget and } \\
\text { costs management }\end{array}$ & $\begin{array}{l}\text { Specific indicators } \\
\text { Action plans developed, validated and implemented } \\
\text { MENRES budget share allocated to EPPs (\%) }\end{array}$ & 54.3 & $\begin{array}{l}\text { Develop } \\
\text { plan } \\
60\end{array}$ & $\begin{array}{l}\text { achieved } \\
64,0\end{array}$ \\
\hline
\end{tabular}

\subsection{Result Analysis}

In keeping with the plan and the management of the Fundamental Education reform, the Education For All Paper was validated, and this allowed access to additional financing, of which the Catalytic Funds from the First Track Initiative that is US\$ 10 millions for 2005, US\$ 25 millions for 2006, and US\$ 25 million for 2007, and a new financing of US\$ 20 million from Norway, and Euro 17 million from AFD. 
Regarding the results obtained against the first specific objective that consist in planning and managing reform under Fundamental Education, it is important to update and validate in 2005 the Education For All document in the reform implementation.

As regards improvement of the quality and efficiency of Fundamental education, actions in recruiting 1,900 teachers in EF1, creating 7,500 new posts and increasing subsidies to the 25, 870 FRAM teachers allowed to improve the pupil/teacher ratio. Furthermore, actions in capacity building and equipment of proximity structures had positive results on the completion rate and the repetition rate that has improved compared with the previous year.

For the specific objective targeting the equity and the access to Education, the kit distribution, and the payment of registration fees and the allocation of subsidies to schools had a positive impact on net enrolment rate, which increased compared with the previous school year. Conversely, despite the important efforts made in construction and repair of 1, 423 EPP classrooms, the objectives were not reached.

In keeping with the improvement of management and accountability at central level of the Ministry of Education, including the budget and cost management, the current priority granted by the government to EF1 is indicated by the obvious increase of the share of the budget of MENRS allocated to EPPs. On the other hand, the MENRS Action Plan was developed, validated and implemented.

As a conclusion, the objectives targeted for the school year 2004-2005 in the Fundamental Education are achieved. However, the success recorded in this sector may raise new challenges in Education in general, would it only be the problem related to the current capacity of the secondary education level, which is rather limited as regards the newly enrolled pupils.

\subsubsection{Subprogram: Post- Fundamental Education}

In Post-Fundamental Education, the specific objective is to ensure the quality and the relevance of Education in relation with economic and social priorities, especially (i) improve the quality of the Secondary Education, (ii) train young qualified people according to predictable and potential jobs (iii) develop the required skills in work environment (iv) improve the quality of the Tertiary Education. 


\subsection{Indicators table}

Table 50: Indicators for Post-Fundamental Education

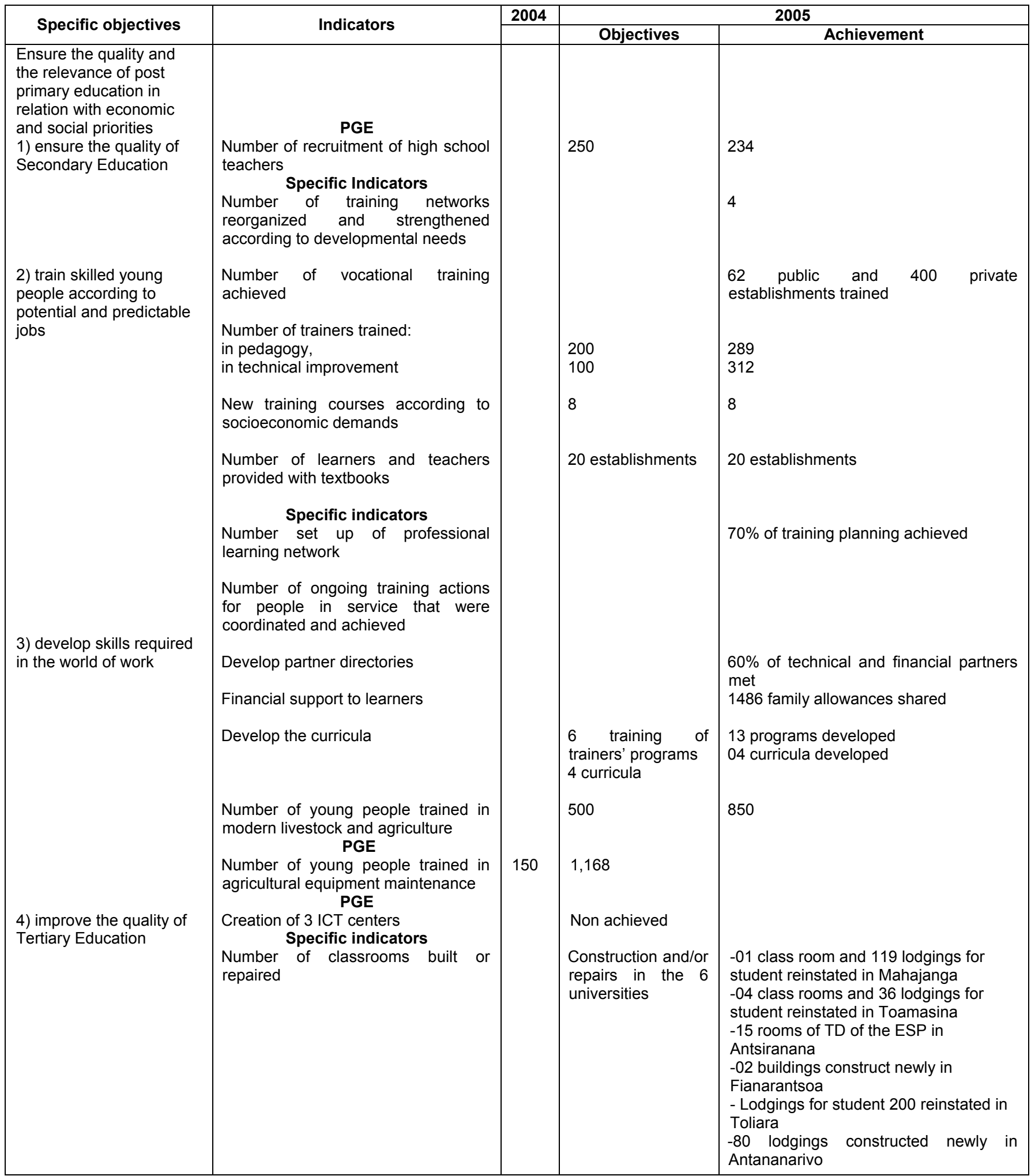

\subsection{Result Analysis}

Regarding the improvement of quality of the Secondary Education, the results obtained relate to the increase in capacity through the construction/ rehabilitation of 45 classrooms and the recruitment of 234 teachers compared to an objective of 250 teachers in Lycée.

Regarding the objective for training young people qualified according predictable and potential jobs, tangible results consist in improving the training/ employment adequacy for young people, and this 
especially originates from the technical improvement among trainers, and from the creation of 8 new education courses that respond to socioeconomic needs.

In developing skills for work environment, the objectives set were also largely exceeded especially among the young people trained in modern agriculture and livestock practices and in the maintenance of agricultural equipment. It is to be noted that the training plans for the 22 regions were validated.

As regards the achievement of the specific objective relating to improvement in Secondary Education quality, works on construction/ rehabilitation of infrastructure in the 6 Universities contributed to increase the capacity among tertiary education institutions.

\subsubsection{Subprogram: Research}

\subsection{Indicators table}

Table 51: Indicators for Research

\begin{tabular}{|c|c|c|c|c|}
\hline \multirow{2}{*}{$\begin{array}{c}\text { Specific } \\
\text { objectives }\end{array}$} & \multirow{2}{*}{ Indicators } & \multirow{2}{*}{2004} & \multicolumn{2}{|r|}{2005} \\
\hline & & & Objectives & Achievements \\
\hline \multirow{3}{*}{$\begin{array}{l}\text { Valorize and } \\
\text { promote the } \\
\text { research in } \\
\text { Madagascar }\end{array}$} & $\begin{array}{l}\text { Strategic documents } \\
\text { Validated }\end{array}$ & & First draft & $30 \%$ \\
\hline & $\begin{array}{l}\text { Number of conventions } \\
\text { signed }\end{array}$ & & $\begin{array}{l}\text { Strengthen scientific } \\
\text { and technical } \\
\text { cooperation }\end{array}$ & 03 \\
\hline & $\begin{array}{l}\text { Number of results } \\
\text { extended in advance }\end{array}$ & & $40 \%$ & $\begin{array}{l}\text { - Set up a site for the extension and the } \\
\text { protection of research results } \\
\text { - Produce } 30 \text { tons of rice seeds, } 250,000 \\
\text { fingerlings, } 1,500 \text { disease resistant banana } \\
\text { plants, } 50,000 \text { disease resistant cassava } \\
\text { cuttings } \\
\text { - } 3 \text { factories treated } \\
\text { - Produce biogas from water hyacinth in the } \\
\text { Pangalanes canal; } \\
\text { Set up } 8 \text { education and ads panels; sensitize } \\
\text { schools and associations within the Park, } \\
\text { repair cages (quarantine, livestock), set up a } \\
\text { phytosanitary laboratory } \\
\text { Air and water pollution assessed at } 100 \% \text { in } \\
\text { Antananarivo and Vinanikarena } \\
\text { Underground water pollution source centers } \\
\text { identified } \\
\text {-1 DTS and } 1 \text { BTS year class graduated } \\
\text { - Production of technical cards } \\
\text { - high return rice variety seeds production } \\
\text { - } 6,355,470 \text { doses produced; } 70 \% \text { cattle } \\
\text { head immunized; } 891 \text { farming vaccination } \\
\text { persons trained } \\
\text { - } 120 \text { seaweed extracts produced } \\
\text { - about ten mushrooms identified } \\
\text { - } 3 \text { rock types value extended } \\
\text { Methods for using anti infection plants and } \\
\text { essential oil plants improved } \\
41 \text { documents published, } 1,867 \text { learners } \\
\text { trained, } 1 \text { regional structure set up } \\
\end{array}$ \\
\hline
\end{tabular}

\subsection{Result Analysis}

Regarding the valorization and the promotion of Research in Madagascar, an overall related strategy was defined, and in keeping with the strengthening of technical and scientific cooperation, financing from the Competitive Funds for Applied Research [Fonds compétitifs de la recherche appliquée (FCRA/PSDR)] were obtained. Furthermore, the objectives in the pre extension of research results were achieved at $40 \%$. 


\subsubsection{Program 12. Development of Population Health}

The four Subprograms implemented are the following: Health, Family Planning, Sexually Transmissible Diseases, HIV/ AIDS, and Ethics

\subsubsection{Subprogram: Health}

The specific objectives of the subprogram Health are to promote mother and child health, to intensify the prevention of transmissible disease, to intensify non transmissible disease prevention, improve access to quality services and improve the performance of health system.

\subsection{Indicators table}

Table 52: Indicators for Health (see errata in page 85)

\begin{tabular}{|c|c|c|c|c|}
\hline \multirow{2}{*}{ Specific objectives } & \multirow{2}{*}{ Indicators } & \multirow{2}{*}{2004} & \multicolumn{2}{|c|}{2005} \\
\hline & & & Objectives & Achievements \\
\hline $\begin{array}{l}\text { Promote Mother } \\
\text { and Child health }\end{array}$ & $\begin{array}{l}\text { Specific/ overall } \\
\text { Maternal mortality rate for } 100,000 \text { living births } \\
\text { Child and infant mortality rate for } 1,000 \text { living } \\
\text { births } \\
\text { DTC, Hepatitis B3 Immunization coverage rate } \\
\text { for children under one year (\%) } \\
\text { Rate of professionally assisted births in CSBs } \\
(\%) \\
\text { Complete immunization rate for children from } 1 \\
\text { to } 11 \text { months (\%) }\end{array}$ & $\begin{array}{l}469(a) \\
94(b) \\
75.1 \\
26,1 \\
53 @\end{array}$ & $\begin{array}{l}285 \\
84,8 \\
84,8 \\
27,1 \\
58,4\end{array}$ & $\begin{array}{l}\text { Non available } \\
\text { Non available } \\
87 \\
19.7 \\
\text { ND }\end{array}$ \\
\hline $\begin{array}{l}\text { Intensify the } \\
\text { transmissible } \\
\text { disease prevention }\end{array}$ & Plague lethality rate $(\%)$ & & $<14$ & 8,3 \\
\hline $\begin{array}{ll}\text { Intensify } & \text { non- } \\
\text { transmissible } & \\
\text { disease } & \text { (MNT) } \\
\text { prevention } & \end{array}$ & Number of centers caring for equipped MNT & & 46 & 92 \\
\hline $\begin{array}{lr}\text { Improve } & \text { access to } \\
\text { quality } & \text { health } \\
\text { services } & \end{array}$ & $\begin{array}{l}\text { Specific/ overall } \\
\text { Population ratio for one CSB } \\
\text { Medical cure consultation rate in the CSB } \\
\text { Chloroquine } \\
\text { Iron, folic acid } \\
\text { Cotrimoxazole } \\
\text { Paracetamol } \\
\text { Vitamin A } \\
\text { Execution rate of medical prescription in the } \\
\text { CSB } \\
\text { Number of functional public CSB } \\
\\
-1 \text { new international hospital } \\
3 \text { CHR operational } \\
2 \text { CHD2 operational } \\
5 \text { welcoming, sorting-out and emergency } \\
\text { (centers) operational, } 23 \text { dentistry offices } \\
30 \text { CSB equipped } \\
80 \% \text { poor have access to free Medicare (list set } \\
\text { by communes) }\end{array}$ & $\begin{array}{l}1 / 5612 \\
49 \\
96 \\
84,5 \\
94,7 \\
90,6 \\
93,5 \\
\\
85,5 \\
2383\end{array}$ & $\begin{array}{l}1 / 7523 \\
58 \\
90 \\
85 \\
90 \\
90 \\
90 \\
90 \\
2266 \\
\\
\text { Work start }\end{array}$ & $\begin{array}{l}\text { Non available } \\
45 \\
56 \\
38.1 \\
56.1 \\
55.2 \\
65 . \\
\\
88,2 \\
\\
\\
30 \% \\
\\
75 \% \\
100 \% \\
100 \% \\
\text { over } 100 \% \\
60 \% \\
100 \%\end{array}$ \\
\hline $\begin{array}{lr}\text { Improve } & \text { the } \\
\text { performance } & \text { of } \\
\text { health system } & \end{array}$ & $\begin{array}{l}\text { Specific } \\
\text { CSB1 and CSB2 staff coverage rate (\%) } \\
\text { Intermediate } \\
\text { Budget share of MPSF allocated to SSD (\%) } \\
\text { Budget execution of the MPSF: } \\
\text { Recurrent non salary } \\
\text { Capital expenditures } \\
\quad \text { PGE } \\
\text { National health program approved }\end{array}$ & $\begin{array}{l}54,07 \\
83,7 \\
86,2\end{array}$ & $\begin{array}{l}100 \\
44,20 \\
85 \\
90\end{array}$ & $\begin{array}{l}54,20 \\
92,56 \\
57,8 \\
100 \%\end{array}$ \\
\hline
\end{tabular}

(a, b, c) source EDS 2003/2004

Objectives and achievements (Non available). Next survey in 2009: the maternal mortality rate reduced to 36 for 100,000 living births, the infant-juvenile mortality rate reduced to 72 for 1,000 , the complete immunization coverage rate at $75 \%$, the plague lethality rate to be replaced by tuberculosis prevalence rate because tuberculosis is a chronic disease prevailing all over the country, whereas the plague prevails in 41 SSD foci, poverty index, in relation with HIVIAIDS 


\subsection{Result Analysis}

Regarding the promotion of mother and child health, positive results were obtained in immunization coverage through outreach and field strategies implemented in the immunization according to the ACD (Reach Each District) (Atteindre Chaque District) approach in the SSD with weak coverage rate SSD and the restart of RRI (Rapid Result Initiative)/PEV of 100 days in 111 SSD. The coverage rate went from $75.1 \%$ in 2004 to $87 \%$ in 2005 , and the objectives largely exceeded.

Regarding the promotion of lesser risk motherhood [maternité à moindre risque (MSR)], the rate of assisted delivery in CSBs declined from 26.1\% in 2004 to $19.7 \%$ in 2005 despite the efforts made to upgrading health agents in MSR and the rehabilitation, as well as the providing of equipments to CSBs.. This is partly explained by the integration of traditional birth attendants who were trained and come from isolated areas in the health system, let alone the deliveries at home assisted by health staff.

As regards Integrated Management of Child illnesses (IMCI), IMCI was reviewed in July 2005, and the National Policy for Child Health was developed and validated. The objectives relating to setting up 52 IMCl functional sites in 2005 were achieved. However the number of these sites among communities is still insufficient.

In keeping with the prevention of transmissible diseases, and in the area of Plague prevention, the objective of maintaining the lethality rate below $14 \%$ was achieved. Results were positive due to specific drug and insecticide supply actions to SSD. But the actions for involving the community in sensitization and epidemiological surveillance still have to be strengthened.

As regards malaria prevention, the results recorded for 2005 were satisfactory: impregnated bed nets and rapid test kits were all acquired and distributed. Nevertheless, the results are still far from meeting the net bed coverage needs.

In prevention of other transmissible diseases, the National Multisectoral Plan of avian flu prevention was developed, and measures were taken for strengthening the surveillance of endemic disease.

As for intensification of the prevention of non transmissible disease, oral health was promoted, in accordance to PGE, and the number of dentistry centers to be set up was achieved. However, efforts have, to be made to improve oral health in communes.

For eye heath, all the objectives relating to active screening and operations of blinding cataract cases, and the ophthalmologic equipment supply were achieved: $3 / 3$ hospital centers (CHU HJRA, CHRR Toamasina and Toliara) were supplied with equipment, 49/49 CSB2 were supplied with cardiovascular disease screening kits, and active screening and operations for 3,879 blinding cataract cases were undertaken.

Regarding the objective of improving access to quality of health services, the ratio population for one CSB slightly improved compared with 2004, even if the 2005 objective was not achieved. Efforts were deployed in the construction of 170 CSB, of which 107 by FID, 197 CSB were built and equipped. Several CSB were damaged by cyclones, and some CSB built by communities are not standardized. New CSB are not operational due to the delay in assignment of health staff recruited in April 2005.

Concerning the evolution in drug availability in the CSBs, the objectives set for 2005 were not achieved. Stock outage periods in tracing essential drugs explain partly the decrease in the use rate of outpatient consultations in CSB. Against PGE, most rehabilitation and equipment work for health facilities are achieved at $100 \%$.

Regarding the improvement of the performance of the health system, the objective in staff coverage rate among CSB1 and CSB2 was not achieved. On the one hand, there are some problems of delay in the assignment documents, and, on the other hand, measures have to be taken for settling CSB2 physicians to their post. On the other hand, the number of budget posts that must allow new recruitments is insufficient. However, the objectives set regarding the human resource development were achieved: 511 doctors, 699 paramedical staff, 152 administrative agents, 141 ECD integrated, 43 surgeon dentists under concession contract, the graduating of 362 paramedical students and the official graduation of 30 Public Health specialist doctors, 20 anesthesia and intensive care agents, and 15 paramedical executives.

Similarly, in keeping with the improvement of the health system performance, the updating of the national health Policy 2006-2008 should provide a more operational reform framework for health programs. The health information and management system was assessed and updated in line with the PRSP. Finally, the administrative structures at decentralized level, the 22 Regional Health and Family Planning Directorates were set up and the health component was integrated in PCD and PDR.

Concerning the establishment of a system for managing the case of the extremely poor people among CSB, the objectives against PGE were achieved 


\subsubsection{Subprogram: Family Planning}

The objective is to extend family planning

\subsection{Indicators table}

Table 53: Indicators for Family Planning

\begin{tabular}{|l|l|l|l|l|}
\hline \multirow{2}{*}{ Specific objectives } & \multicolumn{1}{|c|}{ Indicators } & \multicolumn{2}{c|}{2004} & \multicolumn{2}{c|}{ 2005 } \\
\cline { 4 - 6 } $\begin{array}{l}\text { Extend family } \\
\text { planning }\end{array}$ & Contraceptive use coverage rate (\%) & 7.0 & 5.9 & \multirow{2}{*}{ Objectives } \\
\hline
\end{tabular}

\subsection{Result Analysis}

Regarding the improvement of contraceptive coverage rate in Public and Private Health Formations, results declined compared with 2004, and the objectives were not achieved. However, significant results were obtained in the implementation of system of contraceptive product supply integrated with essential drugs, which was ensured by the purchasing group SALAMA, and the development of the Purchase plan over 10 years, in setting up 161 new PF sites, of which 14 Norplant sites in the Region of Haute Matsiatra and Vatovavy Fitovinany (i.e. 2, 246 operational PF sites), and in the definition of the implementation of the National FP strategy.

Efforts must be continued in securing contraceptive products, facilitating the available quality services FP, strengthening the access to contraceptive products and strengthening sensitization in FP.

\subsubsection{Subprogram: STD/HIV AIDS}

The specific objectives under the Subprogram are (i) to strengthen the institutional framework, the strategic, political, and legal environment, (ii) to improve the access of population to information and prevention means (iii) to improve access to quality services, and to ensure the availability and accessibility of care services and management.

\subsection{Indicators table}

Table 54: Indicators for STD/ HIV ADIS

\begin{tabular}{|c|c|c|c|c|}
\hline \multirow{2}{*}{ Specific objectives } & \multirow{2}{*}{ Indicators } & \multirow{2}{*}{2004} & \multicolumn{2}{|c|}{2005} \\
\hline & & & Objectives & Achievements \\
\hline $\begin{array}{l}\text { Strengthen the } \\
\text { institutional } \\
\text { framework, } \\
\text { strategic, policy and } \\
\text { the } \\
\text { environment }\end{array}$ & $\begin{array}{l}\text { Number of CLLS set up } \\
\text { Number of sub projects financed } \\
\% \text { of communes sensitized }\end{array}$ & & $\begin{array}{l}550 \\
12 \\
35\end{array}$ & $\begin{array}{l}383 \\
3 \\
24,6\end{array}$ \\
\hline $\begin{array}{l}\text { Improve the access } \\
\text { population to } \\
\text { information and } \\
\text { prevention means }\end{array}$ & $\begin{array}{l}\text { Number of TV and radio programs broadcast } \\
\text { Number of OCB s financed } \\
\% \text { blood bags screened }\end{array}$ & & $\begin{array}{l}264 \\
1550 \\
100\end{array}$ & $\begin{array}{l}264 \\
1051 \\
98\end{array}$ \\
\hline $\begin{array}{l}\text { Enhance access to } \\
\text { quality services } \\
\text { Ensure availability } \\
\text { and accessibility to } \\
\text { care services and } \\
\text { medical cost } \\
\text { payment }\end{array}$ & $\begin{array}{l}\text { Number of PLHIV taken care of } \\
\text { Number of Volunteer screening centers installed } \\
\text { or restored } \\
\text { Number of pregnant women syphilis screening } \\
\text { Evolutive syphilis seroprevalence rate among } \\
\text { pregnant women (\%) } \\
\text { HIVIAIDS prevalence rate among pregnant } \\
\text { women (INSTAT) }\end{array}$ & $\begin{array}{l}8.2 \\
1.1\end{array}$ & $\begin{array}{l}300 \\
11 \\
N D \\
5,3 \\
<1\end{array}$ & $\begin{array}{l}209 \\
12 \\
\text { ND } \\
\text { ND } \\
\text { ND }\end{array}$ \\
\hline $\begin{array}{l}\text { Move towards } \\
\text { utilitarian more } \\
\text { health ethics }\end{array}$ & Codes promulgated & & $\begin{array}{l}\text { codes } \\
\text { promulgated }\end{array}$ & codes revised \\
\hline
\end{tabular}

\subsection{Result Analysis}

Concerning the reinforcement of institutional framework and strategic, political, and legal environment in STD/ HIV AIDS, the law $n^{\circ} 031 / 2005$ relative to Right in HIV and PLHIV protection was adopted by the National Assembly, and approved by the Senate. The setting up of CLLS and operational 
coordination structures at the region and commune level, and the sensitization of communes are continues satisfactorily. Communes benefited from a developed and implemented communication plan aiming at a behavior change in STD and HIV AIDS. It is of prime importance to implement a proximity approach anchored to all stakeholders and involving them in AIDS prevention, and to commit local leaders for having operational CLLS.

As regards the objective of improving the access of population to information and prevention means, the objectives were achieved with the sensitization of information programs and television and radio program, as well as the number of blood bag screened. Moreover, 1,000 strategy documents were distributed.

As for promotion of behavior change among individuals, especially for promoting community based interventions, the OCB financing was achieved at $68 \%$, and they play a crucial role in the local response approach. Finally, PLWHIV are managed and the related objectives are achieved in overall; the CTV are set up or repaired and the personnel are trained in CTV.

\subsubsection{Subprogram: Ethics}

\subsection{Indicators table}

Table 55: Indicators for Ethics

\begin{tabular}{|l|l|l|l|}
\hline \multicolumn{1}{|c|}{ Specific objectives } & \multicolumn{1}{|c|}{ Indicators } & \multirow{2}{*}{2004} & \multicolumn{2}{|c|}{ Objectives } \\
\cline { 2 - 4 } $\begin{array}{l}\text { Move towards more } \\
\text { utilitarian public health } \\
\text { ethics }\end{array}$ & Codes promulgated & & Codes promulgated \\
\hline
\end{tabular}

\subsection{Result Analysis}

The implementation of the Ethics Subprogram allowed in 2005 updating the Ethics Code of doctors and the Public Health Code.

\subsubsection{Sub Program: Nutrition}

The following objectives are targeted in nutrition (i) To mainstream and prioritize the prevention of malnutrition in all development programs (ii) to intensify the prevention of malnutrition (iii) to intensify the access to information in the prevention of malnutrition

\subsection{Indicators table}

Table 56: Indicators for Nutrition

\begin{tabular}{|c|c|c|c|c|}
\hline \multirow{2}{*}{ Specific objectives } & \multirow{2}{*}{ Indicators } & \multirow{2}{*}{2004} & \multicolumn{2}{|r|}{2005} \\
\hline & & & Objectives & Achievements \\
\hline \multirow[t]{2}{*}{$\begin{array}{l}\text { 1. integrate and } \\
\text { prioritize the } \\
\text { prevention of } \\
\text { malnutrition in all } \\
\text { development } \\
\text { programs }\end{array}$} & $\begin{array}{l}\text { Specific } \\
\text { - number of sectoral policies using the } \\
\text { malnutrition indicator } \\
\qquad \begin{array}{l}\text { Intermediate: } \\
\text { Set up a memoranda of understanding with } \\
\text { partner ministries; } \\
\text { Develop nutrition sectoral plans }\end{array}\end{array}$ & & $\begin{array}{l}\text { 1. Agriculture, } \\
\text { 1. Agriculture, } \\
\text { 1. Agriculture, }\end{array}$ & 1 (MAEP/ONN) \\
\hline & \begin{tabular}{l}
\multicolumn{1}{c}{ Specific } \\
$\begin{array}{l}\text { Number of regions/communes having integrated } \\
\text { the prevention of malnutrition in their PCD/PRD }\end{array}$ \\
$\qquad \begin{array}{l}\text { Intermediate: } \\
\text { Number of communities having a sensitization } \\
\text { plan in PCIME (IMCl) }\end{array}$
\end{tabular} & & 22 regions & $\begin{array}{l}167 \text { communities } \\
\text { (CRS) }\end{array}$ \\
\hline $\begin{array}{l}\text { 2- intensify the } \\
\text { prevention of } \\
\text { malnutrition }\end{array}$ & $\begin{array}{l}\text { Specific } \\
\text { Number of functional community nutrition sites } \\
\text { having adopted the PNAN model }\end{array}$ & & $\begin{array}{l}110 \text { PNNC } \\
\text { pilot sites of } \\
\text { the } 22 \\
\text { communes }\end{array}$ & 110 pilot sites \\
\hline
\end{tabular}




\begin{tabular}{|c|c|c|c|c|}
\hline \multirow{2}{*}{ Specific objectives } & \multirow{2}{*}{ Indicators } & \multirow{2}{*}{2004} & \multicolumn{2}{|c|}{2005} \\
\hline & & & Objectives & Achievements \\
\hline & 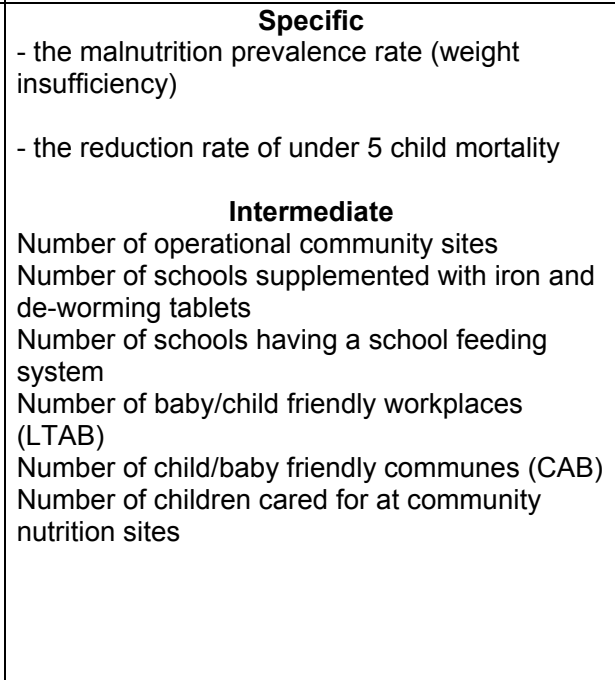 & $\begin{array}{l}3,640 \\
9,270 \\
274 \\
653,166\end{array}$ & $\begin{array}{l}40 \% \text { overall } \\
\text { malnutrition } \\
\text { (weight } \\
\text { insufficiency) } \\
3,640 \text { PNC } \\
\text { sites } \\
11,274 \text { schools } \\
289 \text { schools } \\
5 \text { LTAB } \\
5 \text { CAB } \\
728,000\end{array}$ & $\begin{array}{l}3,640 \\
9,544 \\
289 \\
3 \text { LTAB } \\
2 \text { CAB } \\
693, .000\end{array}$ \\
\hline & $\begin{array}{l}\text { Number of Vitamin A supplemented for children } \\
\text { Number of de-wormed children } \\
\text { Number of iron supplemented for children } \\
\text { Number of primary schools having completed } \\
\text { the iodine salt screening }\end{array}$ & $\begin{array}{l}602,441 \\
2,983,037 \\
1,450,536\end{array}$ & 9,270 schools & $\begin{array}{l}3,074,695 \\
4,659,238 \\
790,816 \\
3,417 \text { schools }\end{array}$ \\
\hline & $\begin{array}{l}\text { Specific } \\
\text { - the coverage rate emergency interventions for } \\
\text { nutrition is implemented } \\
\text { - the proportion of malnourished children } \\
\text { between } 0 \text { to } 59 \text { months externally cared for at } \\
\text { the CSB } \\
\quad \text { Intermediate } \\
\text { Number of operational Intensive Nutritional } \\
\text { Recovery Centers (CRENI) }\end{array}$ & 36 & 44 CRENI & 36 CRENI \\
\hline $\begin{array}{l}\text { 3- improve access to } \\
\text { information in the } \\
\text { prevention of } \\
\text { malnutrition }\end{array}$ & 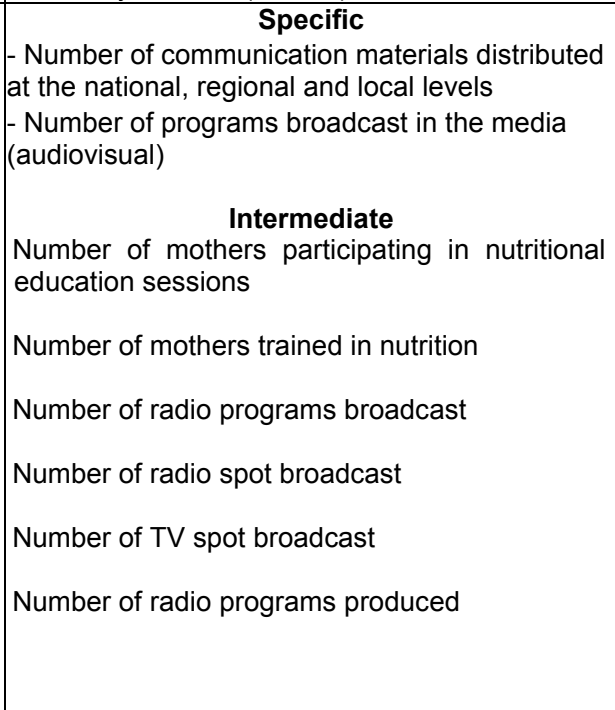 & & $\begin{array}{l}1,600 \\
\text { programs }\end{array}$ & $\begin{array}{l}432,933 \text { mothers } \\
246 \text { mothers } \\
1,581 \text { programs } \\
1,564 \text { radio ads } \\
390 \text { TV ads } \\
52 \text { programs }\end{array}$ \\
\hline
\end{tabular}

\section{$\left(^{\star}\right)$ Source: PNNC/SEECALINE data monitoring}

\subsection{Result Analysis}

With regard to the objective of mainstreaming and prioritizing the prevention of malnutrition in all development programs, the year 2005 was marked with effective start of ONN activities as it is the intervention and actor coordination body in Nutrition

Despite the delay in making available the Budget support funds allocated to ONN in 2005, the protocol objectives and the sectoral nutrition plan that was established with partner Ministries were achieved at $50 \%$. 
As for mainstreaming the strategies for the implementation of the national Nutrition Policy in PCD and PRD, 22 pilot communes were identified with one commune per region.

In intensifying the prevention of malnutrition, the malnutrition prevalence rate among community sites is achieved at $35 \%$ versus an objective of $40 \%$. The actions for intensifying the prevention of micronutrition shortcomings were conducted through the de-worming, the Vitamin a supplementation, which improved compared with last year. However, important efforts still have to be deployed in iron and iodine salt supplementation in schools. The objectives on number of operational sites are achieved. The same applies among school having school feeding structures. As regards the emergency intervention coverage, $81 \% \mathrm{CRENI}$ are operational. Management of children struck by several or moderate malnutrition was strengthened and improved among 966 children.

The objective aiming to intensify the access to information in the prevention of malnutrition, $84 \%$ of mothers are participating in nutritional education, the radio program broadcast achieved $98 \%$ of objectives.

\subsubsection{Program 13. Improvement of Access to Drinking Water and to Sanitation}

\subsubsection{Subprogram: Drinking Water and Sanitation}

The specific objectives of this Subprogram consist in the following:

- Improving the access to drinking water

- Improving the access to sanitation infrastructure

\subsection{Indicators table}

Table 57: Indicators for drinking Water and Sanitation

\begin{tabular}{|c|c|c|c|c|}
\hline \multirow{2}{*}{ Specific objectives } & \multirow{2}{*}{ Indicators } & \multirow{2}{*}{2004} & \multicolumn{2}{|r|}{2005} \\
\hline & & & Objectives & Achievements \\
\hline \multirow{4}{*}{$\begin{array}{l}\text { Improve the access of } \\
\text { population to drinking } \\
\text { water }\end{array}$} & $\begin{array}{l}\% \text { of population having a sustainable } \\
\text { access to a drinking water source }\end{array}$ & 29.4 & & 31,3 \\
\hline & Number of installed works & & 300 & 243 \\
\hline & $\begin{array}{l}\text { Number of functional drinking water } \\
\text { supply systems }\end{array}$ & & 300 (PGE) & $\begin{array}{l}20 \\
243(81 \%)\end{array}$ \\
\hline & $\begin{array}{l}\text { Availability of a working framework for the } \\
\text { Program Budget }\end{array}$ & & $\begin{array}{lr}\text { National } & \text { Drinking } \\
\text { Water } & \text { Access } \\
\text { Program (PGE) }\end{array}$ & $\begin{array}{l}\text { National Program } \\
\text { available }\end{array}$ \\
\hline \multirow[t]{5}{*}{$\begin{array}{l}\text { Improve the access to } \\
\text { sanitation infrastructure }\end{array}$} & $\begin{array}{l}\text { Rate of access in sanitation facilities \% } \\
\text { (INSTAT) }\end{array}$ & 50.0 & & 50,7 \\
\hline & $\begin{array}{l}\text { Positive behavior change towards } \\
\text { hygiene and sanitation }\end{array}$ & & & \\
\hline & Number latrines of built and used & & & 3442 \\
\hline & $\begin{array}{l}\text { Availability of a National Policy for the } \\
\text { coordination of the sector }\end{array}$ & & $\begin{array}{ll}\begin{array}{l}\text { National } \\
\text { policy }\end{array} & \text { Water } \\
\end{array}$ & National Policy available \\
\hline & Diorano WASH program scaling up & & & $\begin{array}{lcc}20 & \text { NGOs } & \text { and } \\
\text { Associations trained }\end{array}$ \\
\hline
\end{tabular}

\subsection{Result Analysis}

The access rate of population to drinking water has improved by $1.9 \%$.

This result was due to various factors: the improvement of the institutional framework, the technical capacity building of stakeholders at all levels, the reorganization of the sector and the setting up of drinking water supply infrastructure.

As regard the PGE, AEP systems were set up, and this achieved the objectives at $81 \%$.

Improved access rate to sanitation facilities was recorded from $50 \%$ in 2004 to $50.7 \%$, which originated especially from latrines construction. A positive behavior change towards hygiene and sanitation was recorded due to a developed communication strategy in that respect, and the scaling up of the Diorano WASH program. The draft policy on the national sanitation policy and strategy was finalized, the sector water policy was developed and a National sector coordination policy is now available. 


\subsubsection{Program 14. Reduction of exclusion, and Social protection}

As the objective consists in promoting the population dimension in development, and in mitigating vulnerability among underprivileged groups, four Subprograms are implemented: (i) Non formal Education (ii) Social Protection (iii) Population and Social Development (iv) Safety Nets

\subsubsection{Subprogram: Non formal Education}

The specific objective in this subprogram is to promote Non formal Education in the Education For All (EFA) framework.

\subsection{Indicators table}

Table 58: Indicators for Non Formal Education

\begin{tabular}{|c|c|c|c|c|}
\hline \multirow{2}{*}{ Specific objectives } & \multirow{2}{*}{ Indicators } & \multirow{2}{*}{2004} & \multicolumn{2}{|c|}{2005} \\
\hline & & & Objectives & Achievements \\
\hline $\begin{array}{l}\text { Promote Non Formal } \\
\text { Education in the EFA } \\
\text { framework }\end{array}$ & $\begin{array}{l}\text { Specific indicators } \\
\text { Number of adults able to read and write } \\
\text { Number of } 11 \text { to } 14 \text { year old adolescents } \\
\text { able to read and write and educated } \\
\text { Operational GIS/EFA } \\
\text { Number of trained technical officials and } \\
\text { GIS/EPT users } \\
\text { Adopted regulatory texts on small } \\
\text { childhood } \\
\text { Number of created multipurpose resource } \\
\text { centers } \\
\text { Number of trained specialized educators } \\
\quad \text { PGE } \\
37,500 \text { people able to read and write } \\
300 \text { trained adult literacy tuition trainers }\end{array}$ & & $\begin{array}{l}37,500 \\
244 \\
71 \text { sites } \\
293 \\
1\end{array}$ & $\begin{array}{l}55,268 \\
244 \\
66 \text { sites } \\
293 \\
1 \\
3 \\
350 \\
55,268 \\
600\end{array}$ \\
\hline
\end{tabular}

\subsection{Result Analysis}

In non formal education, the actions undertaken resulted in exceeded objectives as regards increase in number of people who are able to read and to write, and in improvement of conditions of pre school children who are taken charge of. The legal framework ruling the protection of child rights was improved by developing a draft law relating to supervision of small childhood

\subsubsection{Subprogram: Social Protection}

The specific objective is to set up a coordination system and efficient Social Protection programs

\subsection{Indicators table}

Table 59: Indicators for Social Protection

\begin{tabular}{|c|c|c|c|c|}
\hline \multirow{2}{*}{ Specific objectives } & \multirow{2}{*}{ Indicators } & \multirow{2}{*}{2004} & \multicolumn{2}{|c|}{2005} \\
\hline & & & Objectives & Achievements \\
\hline $\begin{array}{l}\text { Set up a coordination } \\
\text { system and efficient } \\
\text { Social Protection } \\
\text { programs }\end{array}$ & $\begin{array}{l}\text { Adopted national social protection and risk } \\
\text { management policy and strategy Paper } \\
\text { Number of operational structures } \\
\text { Number of beneficiary vulnerable } \\
\text { population by social protection program } \\
\text { type } \\
\begin{array}{l}\text { Number of supported centers for } \\
\text { vulnerable groups }\end{array}\end{array}$ & & $\begin{array}{l}\text { Adopt the National } \\
\text { social protection and } \\
\text { risk management policy } \\
\text { and strategy paper } \\
\text { Set up and have an } \\
\text { operational social } \\
\text { protection institutional } \\
\text { structure } \\
464\end{array}$ & $\begin{array}{l}\text { Drafts developed } \\
\text { An institutional } \\
\text { pattern is defined } \\
\text { and validated } \\
90 \quad \text { households } \\
\text { supported } \\
150 \text { mothers } \\
\text { sensitized } \\
52 \text { social cases } \\
\text { processed }\end{array}$ \\
\hline
\end{tabular}




\subsection{Result Analysis}

Important progress was made in setting up a coordination system and efficient Social Protection programs, especially in the development /validation of first drafts of National policy and strategy for social protection and risk management, the current development of sectors plans according to the recommendations from the June 2005 international conference on Social Protection in Tunis, and the definition and validation of an institutional pattern on the establishment of operational structures.

Regarding the development of operational public expenditure programs for integration and social reintegration of vulnerable groups, the related study financing and cost efficiency analysis of programs are achieved.

Tangible actions i.e. support in food to households and family mothers who received sensitization sessions in nutrition were also achieved.

\subsubsection{Subprogram: Population and Social Development}

The specific objectives of the Subprogram are (i) to promote a culture that takes into account the population/gender/environment dimension in development strategies and programs, and (ii) to promote the implementation of social development programs

\subsection{Indicators table}

Table 60: Indicators for Population and Social Development

\begin{tabular}{|c|c|c|c|c|}
\hline \multirow{2}{*}{ Specific objectives } & \multirow{2}{*}{ Indicators } & \multirow{2}{*}{2004} & \multicolumn{2}{|c|}{2005} \\
\hline & & & Objectives & Achievements \\
\hline \multirow{2}{*}{$\begin{array}{l}\text { Promote the culture that takes } \\
\text { into consideration the } \\
\text { population/gender/environment } \\
\text { in development programs and } \\
\text { strategies }\end{array}$} & $\begin{array}{l}\text { Number of officials and technicians } \\
\text { trained in population and development } \\
\text { planning }\end{array}$ & & 64 & 64 \\
\hline & $\%$ of women in the sphere of decisions & & $\begin{array}{l}300 \text { people }(50 \\
\text { people per province) } \\
6 \text { at provincial level } \\
22 \text { at regional level } \\
\text { Senate } 9 \% \\
\text { ANP } 6 \% \\
\text { Woman member of } \\
\text { the Cabinet } 1 / 21 \\
\text { Head of region } 2 \%\end{array}$ & $\begin{array}{l}300 \\
2 \text { (Antsiranana } \\
\text { and Mahajanga) }\end{array}$ \\
\hline $\begin{array}{l}\text { Promote the implementation of } \\
\text { social development programs }\end{array}$ & $\begin{array}{l}\text { Number of beneficiaries per program } \\
\text { type } \\
\text { Number of instruments adopted } \\
\text { Green card geographic coverage } \\
\text { Number of resource and leisure centers } \\
\text { created for senior citizens } \\
\text { Number of birth compensative } \\
\text { judgments published } \\
\text { Number of births registered per target } \\
\text { zone } \\
\text { Number of centers/NGOs supported } \\
\text { Number of leisure/educational events } \\
\text { created/organized } \\
\text { Number of social public housing } \\
\text { created } \\
\text { Number of NGOs inventoried } \\
\text { PGE } \\
\text { Human trade: at least remain at level } 2\end{array}$ & & $\begin{array}{l}700 \\
1 \\
50,000 \\
2 \\
24,000 \\
5 \\
1,500 \text { OEV } \\
\text { undertaken } \\
900 \text { families } \\
\text { supported } \\
8 \\
200 \\
80 \\
\text { Law } n^{\circ} 2005-014 \text { of } \\
\text { August } 7,2005 \text { on } \\
\text { adoption } \\
\text { promulgated }\end{array}$ & $\begin{array}{l}203 \\
1 \\
30,068 \\
0 \\
42,240 \\
3 \\
1,500 \text { OEV } \\
\text { undertaken } \\
900 \text { families } \\
\text { supported } \\
5 \\
50 \\
39 \\
100 \%\end{array}$ \\
\hline
\end{tabular}




\subsection{Result Analysis}

Despite the sensitization actions aimed for the promotion of the Population/gender/environment dimension into development strategies and programs, the percentage of women who are in the decision making process is still very low. A better planning of activities was done and institutional structures and mechanisms are currently set up in provinces.

As part of the child protection, the law on adoption, as well as the related application decree, was developed, and decrease in traffic of children was recorded.

In the implementation of social development programs, a trend towards general awareness-rising on the responsibilities of community, and especially of economic operators towards elderly people was noticed, and actions relating to distribution of food to the extremely poor families, and training of family heads in AGR resulted in improved well being and material living conditions of the extremely poor families.

\subsubsection{Sub program: Safety Nets}

The specific objectives of the Subprogram are to (i) improve the life quality of the extremely poor households

(ii) to improve the living environment of community (iii) to create permanent jobs and to improve farmer incomes, (iv) to strengthen capacity among communes

\subsection{Indicators table}

Table 61: Indicators for Safety Nets

\begin{tabular}{|c|c|c|c|c|}
\hline \multirow{2}{*}{$\begin{array}{c}\text { Specific } \\
\text { objectives }\end{array}$} & \multirow{2}{*}{ Indicators } & \multirow{2}{*}{2004} & \multicolumn{2}{|c|}{2005} \\
\hline & & & Objectives & Achievements \\
\hline \multirow[t]{3}{*}{$\begin{array}{l}\text { Improve the life } \\
\text { quality of } \\
\text { extremely poor } \\
\text { families }\end{array}$} & $\begin{array}{c}\text { Specific } \\
\text { Number of jobs created }\end{array}$ & $\begin{array}{l}\text { ONN } \\
243,197 \mathrm{~h} / \text { day } \\
17,457 \text { beneficiaries, of } \\
\text { which } 9,990 \text { women } \\
\text { CEPREAS } \\
1,141,315 \mathrm{~h} / \text { day } \\
\text { FID } \\
7,741,140 \mathrm{~h} / \text { day }\end{array}$ & $\begin{array}{l}\text { ONN } \\
499,500 \mathrm{j} / \mathrm{j} \\
33,300 \text { beneficiaries } \\
\text { CEPREAS } \\
2,100,000 \mathrm{man} / \text { day } \\
\text { FID } \\
1,955,090 \mathrm{man} / \text { day }\end{array}$ & $\begin{array}{l}\text { ONN } \\
215,750 \text { man/ day } \\
17,457 \text { beneficiaries, } \\
\text { including } 7,230 \\
\text { women } \\
\text { CEPREAS } \\
2,300,225 \text { man/ day } \\
\text { FID } \\
1,77,843 \text { man/ day }\end{array}$ \\
\hline & CTD reached & $\begin{array}{l}15 \text { regions } \\
33 \text { districts } \\
\\
\\
\\
22 \\
101 \\
475\end{array}$ & $\begin{array}{l}\text { ONN } \\
\text { Regions: } 22 \\
\text { Districts: } 84 \\
\text { Communes: no figure } \\
\text { Fokontany: no figure } \\
\text { CEPREAS } \\
65 \text { districts (part time jobs) } \\
15 \text { districts (reforestation) } \\
\text { FID } \\
\text { Regions } \\
\text { Districts } \\
\text { communes }\end{array}$ & $\begin{array}{l}12 \\
23 \\
34 \\
90 \\
57 \\
16 \\
\\
22 \\
74 \\
227\end{array}$ \\
\hline & Reforested area & 61 ha & $\begin{array}{l}\text { CEPREAS } \\
350 \text { ha }\end{array}$ & 282 ha \\
\hline $\begin{array}{l}\text { Improve the } \\
\text { living } \\
\text { environment of } \\
\text { the community }\end{array}$ & $\begin{array}{l}\text { Specific } \\
\text { Number of infrastructure } \\
\text { \& sites built/repaired } \\
\text { Intermediate } \\
\text { Irrigation canals repaired } \\
\text { Evacuation canals } \\
\text { Maintained small } \\
\text { Trails repairs } \\
\text { Infrastructures arranged } \\
\text { Reforestation } \\
\text { Number of } \\
\text { community projects in } \\
\text { response to emergency } \\
\text { situations }\end{array}$ & $\begin{array}{l}\text { CCPREAS } \\
184 \\
37 \\
\\
\\
18,010 \mathrm{ml} \\
27,841 \mathrm{ml} \\
40,093 \\
298,175 \mathrm{~m} 2\end{array}$ & $\begin{array}{l}\text { CCPREAS } \\
247 \text { infrastructure } \\
100 \text { water supply facilities } \\
\text { ONN } \\
60 \text { projects }\end{array}$ & $\begin{array}{l}\text { CCPREAS } \\
298 \text { infrastructures } \\
72 \text { water supply } \\
\text { facilities } \\
\text { ONN } \\
68 \text { projects } \\
\\
53,457 \mathrm{ml} \\
18,200 \mathrm{ml} \\
53,509 \mathrm{ml} \\
160,606 \mathrm{~m} 2 \\
12 \mathrm{ha} \\
18\end{array}$ \\
\hline
\end{tabular}




\begin{tabular}{|l|l|l|l|l|}
\hline \multicolumn{1}{|c|}{$\begin{array}{c}\text { Specific } \\
\text { objectives }\end{array}$} & \multicolumn{1}{|c|}{ Indicators } & \multicolumn{1}{c|}{2004} & \multicolumn{1}{c|}{ Objectives } \\
\cline { 2 - 5 } $\begin{array}{l}\text { Create full time } \\
\text { jobs and } \\
\text { improve the } \\
\text { incomes of } \\
\text { farmers } \\
\text { (CCPREAS) }\end{array}$ & $\begin{array}{l}\text { Number of full time jobs } \\
\text { and improvement of } \\
\text { farmers incomes }\end{array}$ & 30 & 450 full time jobs & 347 \\
\hline $\begin{array}{l}\text { Build capacities } \\
\text { of communes }\end{array}$ & $\begin{array}{l}\text { Number of PCD } \\
\text { supported }\end{array}$ & & 112 \\
\hline
\end{tabular}

\subsection{Result Analysis}

Actions for building basic infrastructure for the community, economy, or religious denominational groups and public infrastructure were conducted, contributing to improving the living environment of the community, and 2005 objectives were all exceeded.

Substantial results were obtained in improvement of extremely poor household life quality thanks to increase in their incomes through part time job creation on a man/ day basis. Good performances express also, a high demand in social protection due to inflation. Results are yet still insufficient regarding the limited amount of financing that is available, as well as the deterioration in the economy of both urban and rural population. In 2004, FID benefited from an important budget on repairing damages caused by cyclones, allowing it creating a more important number of part time jobs on a man/ day basis.

Tangible results were recorded regarding community infrastructure improvement and development capacity building among communes.

\subsubsection{Sub program: Response to shocks}

The specific objective is to respond and prevent natural disaster impacts or socioeconomic shocks

\subsection{Indicators table}

Table 62: Indicators for Response to shocks

\begin{tabular}{|l|l|l|l|l|}
\hline \multicolumn{1}{|c|}{ Specific objectives } & \multicolumn{1}{c|}{ Indicators } & \multirow{2}{*}{$\mathbf{2 0 0 4}$} & \multicolumn{2}{c|}{$\mathbf{2 0 0 5}$} \\
\cline { 4 - 5 } $\begin{array}{l}\text { Respond to and prevent the effects of } \\
\text { natural disasters or socioeconomic } \\
\text { shocks }\end{array}$ & $\begin{array}{l}\text { Number of infrastructure restored } \\
\text { and repaired } \\
\text { Number of beneficiaries } \\
\text { Number of man/ day jobs created }\end{array}$ & 444 & 355 & Achievements \\
& & & $1,135,065$ & $1,135,388$ \\
\hline
\end{tabular}

\subsection{Result Analysis}

The actions conducted by FID under the Subprogram related to reconstruction and rehabilitation of damaged administrative buildings and creation of full time jobs through social protection actions (HIMO). For the year 2005, the following results were obtained: Infrastructure: $80 \%$, Jobs: $100 \%$

\subsubsection{Program 15. Promotion of Cultural Diversity}

\subsubsection{Subprogram: Culture}

The specific objectives under the Subprogram Culture are (i) to take into account the cultural dimension for development (ii) to promote cultural diversity (iii) to preserve/safeguard, and develop cultural diversities (iv) to set up the bases of cultural industry and encourage the development of arts (v) to promote a publication and public reading policy (vi) to improve the management mode of the culture sector.

\subsection{Indicators table}

Table 63: Indicators for Culture

\begin{tabular}{|c|c|c|c|}
\hline \multirow{2}{*}{ Specific objectives } & \multirow{2}{*}{ Indicators } & \multicolumn{2}{|c|}{2005} \\
\hline & & Objectives & Achievements \\
\hline $\begin{array}{l}\text { Consider the cultural dimension of } \\
\text { development }\end{array}$ & $\begin{array}{l}\text { Number of advocacy campaigns undertaken } \\
\text { Number of studies and research undertaken }\end{array}$ & $\begin{array}{l}6 \\
3\end{array}$ & $\begin{array}{l}0 \\
3\end{array}$ \\
\hline Promote cultural diversity & $\begin{array}{l}\text { Number of sensitization campaigns undertaken } \\
\text { Number of ceremonies created/supported } \\
\text { Number of living human /treasures listed }\end{array}$ & $\begin{array}{l}8 \\
8 \\
12\end{array}$ & $\begin{array}{l}2 \\
4 \\
0\end{array}$ \\
\hline
\end{tabular}




\begin{tabular}{|c|c|c|c|}
\hline \multirow{2}{*}{ Specific objectives } & \multirow{2}{*}{ Indicators } & \multicolumn{2}{|c|}{2005} \\
\hline & & Objectives & Achievements \\
\hline $\begin{array}{l}\text { Preserve/ safeguard and valorize } \\
\text { cultural diversities }\end{array}$ & $\begin{array}{l}\text { Number of cultural sites inventoried and valued } \\
\text { Number of events celebrated } \\
\text { Number of Malagasy participations to cultural events }\end{array}$ & $\begin{array}{l}8 \\
28\end{array}$ & $\begin{array}{l}8 \\
16\end{array}$ \\
\hline $\begin{array}{l}\text { Set up the bases of cultural industry } \\
\text { and encourage the development of } \\
\text { arts }\end{array}$ & Number of cultural centers made functional & 5 & 0 \\
\hline $\begin{array}{l}\text { Promote a public policy of publication } \\
\text { and reading }\end{array}$ & $\begin{array}{l}\text { Number of librarians trained } \\
\text { Number of computer equipments purchased }\end{array}$ & $\begin{array}{l}7 \\
1\end{array}$ & $\begin{array}{l}2 \\
1\end{array}$ \\
\hline $\begin{array}{l}\text { Improve the management system of } \\
\text { the culture sector }\end{array}$ & Number of effective co operations & 9 & 9 \\
\hline
\end{tabular}

\subsection{Result Analysis}

Positive results were recorded in the Subprogram Culture taking into account culture in the development process, respect for cultural diversity, promotion of the Malagasy cultural identity and diversity, and the consideration of Malagasy cultural specificities. The population was encouraged to be interested in reading, and a better distribution of local publication production is also encouraged.

\subsubsection{Subprogram: Youth}

The specific objectives under this subprogram are (i) to strengthen the supervision of young people, (ii) to integrate young people in the development process

\subsection{Indicators table}

Table 64: Indicators for Youth

\begin{tabular}{|c|c|c|c|}
\hline \multirow{2}{*}{ Specific objectives } & \multirow{2}{*}{ Indicators } & \multicolumn{2}{|c|}{2005} \\
\hline & & Objectives & Achievements \\
\hline $\begin{array}{l}\text { - Strengthen supervision } \\
\text { among young people }\end{array}$ & $\begin{array}{l}\text { Number of Chambers of Youth set up } \\
\text { and operational } \\
\text { - Council of Young People set up at all } \\
\text { levels: commune, regional and national }\end{array}$ & $\begin{array}{l}\text { - } 6 \text { Chambers of Youth } \\
\text { - Supervision and } \\
\text { mobilization of } 40 \% \text { of } \\
\text { vulnerable young people }\end{array}$ & $\begin{array}{l}\text { - } 6 \text { Chambers of Youth } \\
35 \% \text { of vulnerable young } \\
\text { people supervised } \\
(482,226 \text { young people) }\end{array}$ \\
\hline $\begin{array}{l}\text { - Mainstream the dimension } \\
\text { youth into development } \\
\text { processes }\end{array}$ & $\begin{array}{l}\text { - Number of young people, especially } \\
\text { rural ones, oriented to development } \\
\text { actions }\end{array}$ & & \\
\hline $\begin{array}{l}\text { Promote sport for all and } \\
\text { traditional sport practice }\end{array}$ & $\begin{array}{l}\text { - Number of sport facilities built } \\
\text { - Construction of a multi-sports } \\
\text { complex }\end{array}$ & $\begin{array}{l}\text { - } 12 \text { sports facilities } \\
\text { One complex built }\end{array}$ & $\begin{array}{l}\text { - } 11 \text { sports facilities } \\
\text { Construction postponed }\end{array}$ \\
\hline \multirow[t]{4}{*}{$\begin{array}{l}\text { Support high level sport } \\
\text { practice }\end{array}$} & $\begin{array}{l}\text { Number of young athletes selected and } \\
\text { trained }\end{array}$ & -250 athletes & - 348 athletes \\
\hline & - Sport equipment bank & & \\
\hline & - Stadiums and swimming pools Built & $\begin{array}{l}-6 \text { stadiums } \\
\text { - }\end{array}$ & - 9 stadiums \\
\hline & - Sports improvement centers created & & \\
\hline
\end{tabular}

\subsection{Result Analysis}

Young vulnerable people now show responsible behavior following interventions in that area. This result was especially recorded due to actions for supervising young people, including the setting up of young people councils at all levels and operational Chambers of Youth

\subsubsection{Sub program: Sports}

The objectives are to promote sport for all and traditional sport practice, and to support high level sport practice. 


\subsection{Indicators table}

Table 65: Indicators for Sports

\begin{tabular}{|c|c|c|c|}
\hline \multirow{2}{*}{ Specific objectives } & \multirow{2}{*}{ Indicators } & \multicolumn{2}{|c|}{2005} \\
\hline & & Objectives & Achievements \\
\hline $\begin{array}{l}\text { Promote sports for all and traditional } \\
\text { sports practice }\end{array}$ & - Number of sports facilities built & - 12 sports facilities & - 11 sports facilities \\
\hline \multirow[t]{4}{*}{ Support high level sports practice } & $\begin{array}{l}\text { Number of young athletes selected } \\
\text { and trained }\end{array}$ & -250 athletes & - 348 athletes \\
\hline & - Sport equipment bank & & \\
\hline & $\begin{array}{l}\text { - Stadiums and swimming pools } \\
\text { Built }\end{array}$ & - 6 stadiums & - 9 stadiums \\
\hline & $\begin{array}{l}\text { - Sports improvement centers } \\
\text { created }\end{array}$ & & \\
\hline
\end{tabular}

\subsection{Result Analysis}

Concerning the development of sports, efforts were especially made on the construction and the rehabilitation of sport facilities, providing high level training for selected athletes, and the rehabilitation of sport infrastructures according to conventional standards. The related actions were achieved and produced positive results in 2005; i.e. on better practice of sport by the population, on one hand, and on breakthrough of high level athletes at international level, on the other hand.

\subsubsection{Performances of Large Projects}

The CRESED II project strongly participated in the increase of the enrolment rate. The CRESED, FID projects and OPEP funded projects contributed to the construction/rehabilitation of EPPs and CEGs, to the training of teachers, to the recruitment of contractual teacher and to subsidization, as well as to the improvement of the quality of education. The major part of CRESAN II project objectives is practically achieved: increased rate of CSB external consultations, construction, equipment, training, and malaria, tuberculosis, and bilharzias prevention. The CRESAN II, FID, projects, the ADB funded projects largely contributed in the rehabilitation/construction of health infrastructure. As regards HIVIAIDS prevention, the PMPS project capitalizes and develops IEC activities. Under the USAID funded Health Project, the objective for malnutrition prevention is nearly achieved. The objective for the sales of contraception medication and tools has exceeded all over the country through social marketing. The SEECALINE, FID, CCPREAS projects combine their efforts for poverty reduction and social protection reinforcement by creating jobs and reducing the rate of child malnutrition. The implementation of water and sanitation projects indicated a good performance over the year 2005 . The objectives for drinking water supply works are nearly achieved. Having sustainable infrastructure sometimes induces some problems. 


\section{SYNTHESIS OF REGIONAL WORKSHOPS}

Concerning the implementation of PRSP over the year 2005, regional workshops were organized by STA in the 6 main provincial towns during the month of February 2006. The objectives of such workshops are the following:

- share the relevant information of the PRSP process with regional stakeholders (provincial and regional authorities, deconcentrated service officials, private sector and civil society representatives): presentation of the National Report and the Regional Reports as regards the implementation of PRSP in terms of achievements in the first semester of 2005;

- collect information and data related to PRSP implementation at the regional scale, complementing the sectoral information provided by central level ministries, thus allowing highlighting the common points and specificities of Provinces and Regions, not only as regards achievements in development actions, but also as regards constraints and issues;

- have overall perceptions from regional stakeholders over the main aspects of the PRSP process: coordination of central, sectoral, and regional programming; setting up of the integrated monitoring and evaluation system of PRSP at central, sectoral, and regional levels, the main related constraints.

The results of such Regional Workshops may be summarized as follows:

Overall slight decrease is recorded compared with 2004 . This situation is explained especially by the constraints that are linked to the first implementation of the program budget: delay in financial resource disbursement, appointment and training of new officials in public expenditure execution ("sous ordonnateurs secondaires", activity managers).

The other constraints to the implementation of PRSP at the regional level are the following:

- At institutional level: lack of clarification in division of missions and responsibilities between central level ministries and the Decentralized Territory Local collectivities (CTD) in terms of programming, management, and checking of action of interest to regional, commune and local development;

- At technical level: inappropriate capacity, in general, and human and technical resources in particular in CTDs and deconcentrated services;

- At the financial level: insufficiency of budget resources made available to CTD for the implementation of PRD and PCD.

- Despite such constraints, significant achievements were recorded in the 3 strategic orientations of PRSP.

\section{Governance}

As regards good governance and the establishment of the Rule of Law, the relevant achievements which are worth highlighting involve the following sectors and areas:

- Decentralization and deconcentration: support, guidance, and checks among local and regional officials; training in budget management of close to $80 \%$ commune officials, especially in the provinces of Antananarivo and of Mahajanga; establishment of the Local Development Funds (FDL) for CTD; equipment of CTD in office supplies and means of transportation; construction of buildings for newly created communes; equipment in computers and communication materials, as well as office supplies for the 22 Regions;

- Security: rural security, especially in hot spots and potential zones. The settling of Autonomous Security Detachments [Détachements Autonomes de Sécurité (DAS)] in the Region of SAVA (2 units) and in the Regions of the Fianarantsoa Province (15 units) allowed the reduction of insecurity rate by up to $90 \%$ and to give back up to $75 \%$ stolen cattle, especially in the Regions of Ihorombe and Haute Matsiatra. Securing the mining operating sites engenders decrease in crime and theft rates by $72 \%$ and under in the Region of Ihorombe. For the province of Mahajanga, in addition to the Overall Police Rounds [Tournées de Police Générale (TPG)], the extension of Village Self Defense called "Kalony" and the setting up of gendarmerie stations engendered decrease in human bone thefts (tomb raids) and a cattle recovery rate of $96,5 \%$. The positive impacts of securing actions in rural areas are tangible in the Regions of Melaky and Sofia. In urban areas, the setting up of community based police stations and a better spatial coverage obviously reduced crime and organized crime, especially in the provinces of Antananarivo and Toamasina.

- Justice: the establishment of a financial and administrative court in each main provincial town, the multiplication of penal courts so as to expedite the processing of "dahalo" files, more particularly in the Province of Fianarantsoa. In penitentiary matters, the humanization of imprisonment is 
recorded through improved food, construction and rehabilitation of prison buildings. Such actions allowed the reduction of mortality rate in prisons by $1.6 \%$ in 2005 , especially in Toliary.

- Civil Service Reform: "PAOTOKANA" operation conducted in 2004, and continued in 2005 that allows a regularization of the situation of about twenty thousand civil servants into private workers; establishment of OMEF and JIVA, in the Regions of Haute Matsiatra and Amoron'i Mania, so as to reduce unemployment among young people.

\section{Production and Investment}

The actions relevant to economic development which are worth mentioning as regards 2005 are the following:

- Economic management and planning: Regional directorates and Services in economy and planning support the regions through training in PRD development and implementation. They, in addition, published socioeconomic regional brochures (Antananarivo, Toamasina, Fianarantsoa), and undertook diagnoses for each region, and made up a regional database, and publish regional monograph (provinces of Antananarivo, Mahajanga, Toliary). These exercises are related to the process for setting the Regional Information System (SIR).

- Public Expenditure Management: SIIGFP was set up, and this allowed an $85 \%$ performance rate in file processing in 2005 versus $75 \%$ in 2004, for the Provinces of Fianarantsoa and Antananarivo. New software is used and the main people in charge of the execution of program budgets (ordonnateurs secondaires, activity managers, person in charge of public procurement) were trained, and this decreased from 72 hours to 48 hours the time limit to process a file, and reduced the number of rejected files from $40 \%$ in 2004 to $3 \%$ in 2005, for the Provinces of Antananarivo and Fianarantsoa. Tax, including arrears collection, indicates overall improvement, particularly in the Province of Toliary where the amount collected in 2005 accounts for about 20 times more the amount collected in 2004.

- Rural Development: the agricultural production indicates significant increase, and this was due to the use of improved seeds, the maintenance and the rehabilitation of irrigated perimeters, the promotion of modern agricultural techniques, and the distribution of agricultural materials. Rice production increase rate went from 13\% in 2004 to $15 \%$ in 2005, in the Province of Antananarivo and in the Regions of Menabe, Boeny, and Alaotra Mangoro. as concerns land ownership security, a $40 \%$ increase was recorded between 2004 and 2005 in the number of land titles that were distributed in the Regions of Menabe and Alaotra Mangoro which are part of high potential Regions. Income generating activities, which was financed by PSDR, contributed to increase the production in fish breeding, poultry farming, and apiculture in such Regions.

- lake fish restocking and good management of fishing schedule allowed the revitalization of the fishing sector. Fresh water fish production increased by $10.2 \%$ between 2004 and 2005, especially in the Regions of Itasy, Alaotra Mangoro, and Betsiboka. Furthermore, cattle immunization coverage rate went from $65 \%$ in 2004 to $82.2 \%$ in 2005 . The best performances are recorded especially in the extensive breeding areas such as the Regions of Menabe, Androy, Sofia, Melaky, and Bongolava. Thus, the $2 \%$ average annual cattle head increase rate is achieved in these Regions.

- Environment, Water and Forests: environment management was transferred to grassroots communities regarding about $69 \%$ of renewable natural resources, especially in the Regions of Menabe, Androy, Anosy, and Melaky. It is also important to mention that operations of reforestation, bushfire prevention, and erosion prevention were conducted. Reforestation operations involve especially the Regions of Bongolava, Alaotra Mangoro, and Atsinanana. Various crops which are likely to generate additional incomes were introduced to rural populations.

- Land Management: Master town planning Schemes were developed (Antananarivo, Antsirabe, Tsiroanomandidy, Manjakandriana); urban communes were endowed with materials, commune infrastructure were built and repaired, especially in the Provinces of Toamasina and Mahajanga.

- Transportation and roads: the national road network and rural roads were maintained and repaired, engineering works were maintained and repaired (essentially bridges) especially in the Provinces of Antananarivo and Toliary; transportation licenses and authorizations were issued; bus stations were rearranged and cleaned in the Regions of Atsinanana and Analamanga.

- Meteorology: meteorological centers were set up in the high agricultural potential Regions such as Bongolava, Analanjirofo, and Itasy; provincial services were created in Toamasina and Antananarivo.

- Post and Telecommunication, Communication: new products such as postal savings, post transportation services were started; fixed and GSM mobile phone coverage has extended; VSAT and CDMA were set up for isolated areas especially in the Provinces de Toliary and Toamasina; 
journalists were trained, and radio and TV studios were endowed with digital video/audio editing materials for the 22 Regions.

- Trade and Private Sector Development: operational regional branches of CAPE and GUIDE were set up; artisans and SMEs were trained and formalized especially in the Regions of Atsinanana, Haute Matsiatra, and Amoron'i Mania; information systems were set up and databases were managed; import products were checked and standardized; export was promoted, and the related revenues reached ten times more their value in 2004 for the Province of Fianarantsoa.

- Tourism: Madagascar is promoted as a destination, hence double number of foreign tourist arrivals in 2005 versus 2004 especially for the Provinces of Antananarivo, Toliary, and Mahajanga; tourism activities and buildings were standardized and checked; new tourism sites were prospected; ecotourism was started and valorized; tourist tax stamps were collected, and the collection rate reached $65 \%$ in 2005 in the provinces of Fianarantsoa and Antananarivo.

- Mining: mining artisans were trained; mining royalties were collected and the related rate went from $4.49 \%$ in 2004 to $52.14 \%$ in 2005 in the Regions of Ihorombe, Androy and the Province of Antananarivo; export of processed mining products was promoted; research and operating permits were granted; Regional Mining - Forest Committees were set up in the Regions of DIANA, Ihorombe, and Androy; rushes towards mining operations sites were contained through accountability of regional authorities and officials.

\section{Social Aspects}

In the social area, the achievements and results which are deemed relevant are listed herein after:

- Education: enrolment fees and FRAM teacher subsidy management was continued; in service/on the job training was provided to teachers at all levels especially regarding competency based approach; chefs ZAP and chefs CISCO were trained and equipped with materials; kit and textbook provision was continued, hence decrease in repetition rate $28 \%$ in 2004 to $16.2 \%$ in 2005 in the Province of Fianarantsoa.

- Vocational Training and Technical Education: interest bearing clusters were created in the Provinces of Fianarantsoa and Antananarivo (in Mantasoa); itinerary training was organized among the rural population, especially in the Region of Amoron'i Mania.

- Health: mother and child health was promoted, allowing an increase of the immunization rate from $46.1 \%$ in 2004 to $80.93 \%$ in 2005 among children under 1 year old in the Province of Toliary; safe motherhood was promoted, and this engendered an increase in the rate of professionally assisted births which moved from $13.58 \%$ in 2004 to $21 \%$ in 2005 in the Regions of Bongolava, d'Atsimo Atsinanana; equity funds for poor people was established in each CSB; family planning was promoted, and a $12 \%$ increase in contraceptive coverage rate was recorded from $12 \%$ in 2004 to $25 \%$ in 2005 through the application of the Rapid Result Initiative (RRI) in the Region of Analamanga; CTV, PMTCT sites and Referral centers were set up in AIDS prevention; transmissible and non transmissible disease prevention was continued; STD/AIDS management continued among health centers which are scattered in all Regions.

- Safety Net and Social Protection: provisional AGR was created through HIMO (labor intensive work) system in community infrastructure construction and repair, which were financed by FID, ONN/SEECALINE, and CCPREAS, particularly in the Regions of Analamanga, Haute Matsiatra, and Androy; basic commodities distribution was continued to civil servants and wage earners whose monthly income is lower than or equal to $\operatorname{Ar} 100,000$ in all Regions.

- Population: the EKA operation continued, green cards were distributed to elderly people, literacy tuition to young school dropouts in all Provinces.

- Youth and Sport: sport facilities were built; SRA was extended; mass and high level sport events were held; cultural festivals were organized.

- Culture: librarians were trained; CLEFs were established especially in the Provinces of Fianarantsoa and Antananarivo; regional cultural events were organized. 


\section{MAIN RECOMMENDATIONS}

The information provided by Ministries under PRSP implementation monitoring for 2005 was used and this identified two categories of constraint: (i) general constraints, and (ii) specific constraints.

General constraints involve the execution of public expenditure and the coordination of development actions. As the Program Budget has been published since 2005, public expenditure execution indicated some delay that was due to the necessity to appoint and train new officials (Ordonnateurs Secondaires, Gestionnaires d'Activités), and People in charge of Public Procurement. In the area of national and sectoral policy coordination, constraints are recorded at various levels. Regarding national and sectoral policy coordination, low institutional capacities among institutions and ministries reflected in the delay noticed in the process for developing or updating national plans or programs that involve several ministries and integrate donor support.

In that respect, effort should continue in order to improve inter ministry coordination regarding the process of building institutional capacities among coordination bodies at all levels: Presidency (strategic coordination), Prime Minister's Office (operational coordination), MEFB, the other Ministries and the Regions. The clarification of missions, roles and institutional responsibilities in conjunction with the promotion of local governance should considerably improve the results and impacts of development actions. For the case of sectoral coordination, one Ministry involved might be appointed as a Leader for the achievement of some specific objectives.

The improvement of transparency and information flow among Ministries through the establishment of an inter-ministry data base within the State Intranet should contribute to strengthening the government coordination schemes.

With regards to the specific constraints recorded among the 3 strategic orientations of PRSP, as well as the related major recommendations, they are the following:

\subsection{ORIENTATION 1: GovernANCE AND RULE OF LAW}

\subsubsection{MAIN CONSTRAINTS}

The main issues recorded among the Ministries in charge of programs related to good governance and establishing the Rule of Law relate essentially to institutional, technical, and financial aspects.

At the institutional level, a lack of coordination among Ministries involved in achieving the overall objectives stands as the main constraint. The low level of inter ministry coordination in security and defense restricts efficiency over the activities, as a whole, which are conducted by the various ministries involved.

At the technical and financial levels, what is noticed is the lack of arbitration tool regarding the allocation of financial means required for completing the missions of various ministries involved in defense and security. The ministries in charge of national security and defense lack technical resources to face the magnitude of security problems in both urban and rural areas.

Similarly, the decentralization/deconcentration process may run the risk of being delayed by slow process in strengthening the Decentralized Local Collectivities [Collectivités Territoriales Décentralisées (CTD)] and Deconcentrated Services in terms of human, material and budget means.

\subsubsection{MAJOR RECOMMENDATIONS}

A national policy relative to the integrated defense concept that includes security and safety has to be elaborated. At least, 5 Ministries are directly involved by defense and security, namely: the Ministry of National Defense, the Ministry in charge of Foreign Affairs, and the Secretariat in charge of Public Security. A set of institutional, legal, technical, and financial schemes have to be attached to such Policy, allowing for the achievement of the Government objectives regarding security and defense. The mainstreaming of the security dimension into the national, regional, commune development Programs should be envisaged in a systematic manner.

Similarly, each Ministry should establish and implement a work plan relative to the national decentralization/ deconcentration policy under the coordination of the Presidency, the Prime Minister's Office, and the Ministry in charge of Decentralization. Furthermore, Ministries should be subject to a capacity building plan regarding decentralization/deconcentration.

\subsection{ORIENTATION 2: PROdUCtion AND ECONOMY}

\subsubsection{MAIN CONSTRAINTS}

At the institutional level, poor inter ministry coordination is very much felt in the implementation of economic development programs. Interdependence among some sectors is generally not taken considered when scheduling government actions at various sector levels. As an example, the 
development of telecommunication services and the promotion of processing (agro-industry, small manufacturing companies,) units, in emote areas is considerably handicapped by the delay in the electrification program progress. Similarly, the promotion of Tourism Investment Areas [Zones d'Investissement Touristique (ZIT)] is hindered by non programming of other services and infrastructure which are required (roads, electricity, water, telecommunication,).

At the technical and financial levels, private operator intervention capacities are overall limited compared with the needs expressed in the transportation and road sectors, rural development (agroindustry) and energy. Such constraints are noticed in multiple shortcomings recorded in the implementation of projects for road building, construction and rehabilitation, as well as electrification projects (execution time frame, contract termination to the fault of contractors)

\subsubsection{MAJOR RECOMMENDATIONS}

The following is necessary:

- To improve inter ministry coordination in terms of sectoral policy development and implementation, at large, and public investment projects, in particular; in that respect, the Land Management Master Plans should serve as a reference framework for infrastructure project coordination at national, regional, and commune levels; and

- To develop and implement a specific work plan for the promotion of Public/ Private Partnership , the aim of which is not only to improve the institutional and legal framework, but also technical and financial capacity building among private operators in priority and interest bearing sectors (infrastructure, rural development, energy, and tourism);

\subsection{ORIENTATION 3: SOCIAL ASPECTS}

\subsubsection{MAIN CONSTRAINTS}

The constraints that are estimated as the most important involve the implementation of social programs, and they include the following:

- At institutional level, the poor institutional capacity of Ministries in programming, management, and monitoring and evaluation of public policies;

- At technical and financial levels, the non-appropriateness of the available means to the needs, especially in sub sectors: Non Formal Education (ENF), Post Fundamental Education, among which are: Technical Education and Vocational Training, Tertiary Education, Research, Water and Sanitation, Youth and Sport. The lack of visibility is also worth mentioning regarding the sustainability of investment in social infrastructure;

\subsubsection{MAJOR RECOMMENDATIONS}

With a target of addressing such main constraints, the following actions and provisions have to be taken:

- Prioritize support to Ministries in charge of social sectors in keeping with the program for strengthening public policy planning, programming, monitoring and evaluation capacities; such support should provide for mastery of tools to evaluate financing needs for the achievement of medium and long term objectives;

- Develop and implement Public/ private partnership strategies in social sectors so as to ensure actions and investment sustainability.

Moreover, in order to prevent the risks of non achievement of objectives in the health sector, the Ministry in charge of this sector should decide with MEFB about the solutions aiming at improving budget execution performance. Such solutions should provide, amongst others, for procedure simplification, and capacity building to officials in deconcentrated services. 


\section{MONITORING AND EVALUATION}

\subsection{ACTIONS COMPLETED IN MONITORING WORK}

Since the implementation of PRSP in July 2003, improvements have been brought to monitoring work. In the light of acquired experience, work methodology and organization improved in the relationships between various institutions that are involved in the national monitoring system, working tools, thematic and regional workshops, information processing and analyses, and plans that were adopted for various monitoring reports.

\subsubsection{Actions undertaken by the Government (Presidency, Prime Minister's office, Technical Secretariat to Adjustment, instat, Directorate General of Planning, MINISTRIES):}

The Technical Secretariat to Adjustment, which is the secretariat to PRSP Technical Units, ensures the coordination and the facilitation for works related to the PRSP implementation monitoring. In that regard, STA organizes all monitoring technical works and ensures the task to summarize analyses in collaboration with:

- Ministries and deconcentrated Services which provide information relative to achievements and indicator evolution

- INSTAT which analyzes the poverty evolution with the main PRSP monitoring indicators, the Directorate General of Economy for the analysis of the economic and financial evolution, as well as budget execution per strategic orientation

- The Directorate General of Planning regarding project and program performance

In keeping with the improvement of the monitoring system at national level, the Prime Minister's Office initiated with the above mentioned various ministries series of work meetings (April, May, December 2005, and February 2006) so as to harmonize approaches and working tools. The results of such work converged in the improvement and articulation of working tools in PRSP monitoring, of the General Policy of the State, of Public Investment Program and Public Expenditure Program.

Furthermore, the Directorate General of Planning conducted capacity building workshops for officials at of regional, commune, district, and deconcentrated service level, as well as for the civil society in the Regions Bongolava and Itasy. The training sessions focused on result oriented management, and the themes related to: (i) the main lines and interrelations between the Millennium Development Goals, the Vision Madagascar Naturally the PRSP, and the PRDs, (ii) the monitoring and evaluation tools (logical framework, Indicators, reporting format) and (iii) the manual of procedures for the regional monitoring and evaluation system. ..

\subsubsection{QUARTERLY WORKSHOPS FOR THEMATIC GROUPS:}

During the year 2005, the 3 thematic groups for PRSP implementation monitoring met every quarter with the participation of Ministries, projects, programs, private sector, and civil society. Such thematic workshops were conducted by the PRSP Technical Unit, and coordinated and facilitated by the Technical Secretariat to Adjustment:

- February 09 and 10, 2005: situation from September to December 2004, and preparation of annual report for the year 2004.

- May 10 and 11, 2005: situation from January to March 2005, and preparation of annual report for the year 2004

- July 21 and 22, 2005: situation from April to June 2005

- December 20 -21, 2005: situation from July to September 2005

January 27, 2006: informative meeting for the preparation of 2005 annual report the thematic groups was organized as follows:

- Governance: public finance, public security, national defense, decentralization, foreign affairs, administrative reform, and interior, civil service, labor and social laws, corruption prevention

- Economy: public management and finance, private sector / industry / handicraft / trade, tourism, agriculture / fishery / livestock, environment/ water and forests, energy / mining, transportation / public works / land management, post / telecommunication / communication

- Social Aspects: health, STD/ AIDS, education, population, youth and sports, safety nets, culture, water / sanitation, nutrition 


\subsubsection{Regional Workshops in Faritany}

Biannual workshops were organized in the main provincial towns, complying with the Public/ Private Partnership principle and the participative process during the months of February and March 2005 regarding achievements during the year 2004 and during the months of August and September 2005 regarding the achievements during the first semester 2005. Considering the limited number of Ministries having Regional Directorates in Regions, holding workshops in Regions is still difficult.

These workshops provided STA with the opportunity to present and distribute the various reports of the PRSP implementation at national and regional levels:

- $\quad$ Annual PRSP implementation report for the year 2004

- $\quad$ PRSP implementation report in the provinces (per Faritany)

- $\quad$ PRSP update in June 2005

\subsubsection{PRSP IMPLEMENTATION REPORTS}

In order to have the PRSP monitoring reports to coincide with budget year, a monitoring report covering the whole year 2004 was developed in June 2005. For the year 2005, a semester PRSP implementation report was developed in November 2005. Furthermore, regional PRSP implementation reports were developed in May 2005 regarding the 2004 achievements, and in September 2005 regarding the first semester 2005 achievements.

\subsection{HAVING AN OPERATIONAL PRSP IMPLEMENTATION MONITORING SYSTEM}

\subsubsection{LESSONS LEARNT}

\subsubsection{What was gained from the process}

Periodical and regular workshops and working meeting at national and regional levels have facilitated the establishment of ongoing and monitored professional relationships between STA and its various partners.

The PRSP implementation monitoring contributed to the improvement of the information collection system at national and regional levels. Effective ownership was noticed among the various Ministries and diverse deconcentrated services, as well as project and program tools, and working methodology.

On the other hand, these meetings allowed Ministries to exchange inter sector information and to create synergies in the implementation of program. The cases of water and health sectors, FID and CEPREAS are illustrative of this point.

As regards the relationships with technical and financial partners, a partnership framework was set up to monitor the PRSP implementation. Joint Government/ donors reviews were held twice a year in April and September of each year.

\subsubsection{Improvements brought about}

With the aim of improving the quality of information and analyses included in the PRSP monitoring report, innovations were brought in at technical and organizational levels. Specific and intermediate indicators linked to the objectives of each subprogram were identified to improve analyses compared with the objectives. Furthermore, social indicators were harmonized with technical and financial partners in the programs of support to the implementation of the PRSP. Moreover, budget executions were analyzed per strategic axis of the PRSP regarding the financing of poverty reduction strategy.

At organizational level, in order to have information on public expenditures through every four months review of the public expenditure and to coordinate monitoring actions, thematic workshops will be organized every four months.

\subsubsection{Implementing the PRSP at regional level: stakes and challenges}

Regarding the implementation of the monitoring system of the PRSP at regional level, working meetings were held with officials from 22 regions and with STA to explain the current PRSP monitoring system. The plan for system implementation at regional level was put forward, for better articulation of actions at national and regional levels.

Holding workshops to monitor the implementation of the PRSP was still difficult at technical and logistic levels because only the Ministry of Agriculture, Livestock, and Fisheries, and the Ministry of Health and Family Planning have Regional Departments. Furthermore, most Regions do not have a monitoring structure and system yet that is defined to implement the programs at regional level.

The officials at regional level raised the issue of information sharing between deconcentrated services and regions because the texts are not applied and the Region officials do not have any effective power 
over the deconcentrated services. Moreover, technical capacity in monitoring and evaluation among human resources, and the means at the Region disposal are still limited.

To make STA and INSTAT monitoring activities operational,, the current financing that is allocated does not cover the actions that were programmed.

\section{Plan for an operational monitoring system}

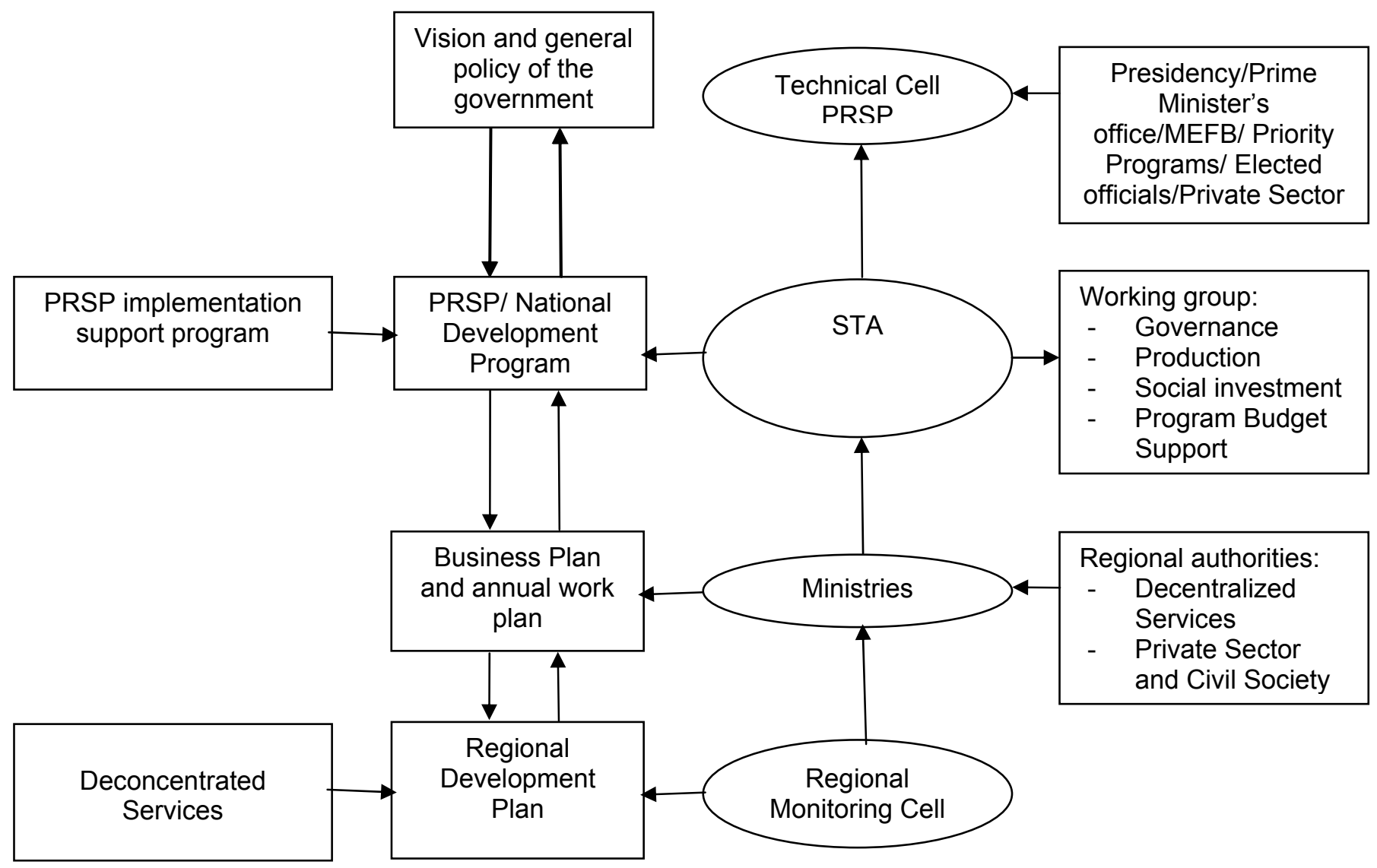

\subsubsection{Challenges}

\section{Ministries}

A structure in charge of monitoring and evaluation has to be set up within each Ministry to improve the information system to have timely and reliable data. This system will have to allow for complete information on the sector achievements including those from private sector, NGOs, and projects.

Considering the first activity experiences in the monitoring of the PRSP implementation, capacity building actions among institutions in charge of PRSP monitoring prove to be necessary in order to improve capacities to analyze and process information. Particular problems were noticed among the indicators regarding their identification and interpretation.

\section{Regions}

At regional level, monitoring structures have to be set up to coordinate actions for the collection and the processing of information on achievements made by Regional Directorates, the private sector, and the civil society in keeping with the implementation of Regional Development Programs.

Regarding the establishment of an operational national coordination system for PRSP monitoring, the actions to be undertaken must aim at the capacity building, the standardization of working tools, the , consideration of each region's specificities, especially on the opening up plan, and the decision making at strategic level to clarify and establish the roles and powers of Regional Officials over Deconcentrated Services. Furthermore technical support from STA was solicited by the Regions to set up monitoring structures and to have an operational system.

Harmonization and coordination 
The efforts undertaken to harmonize the working tools, that were already initiated within the President's Office, the Prime Minister's Office, the Technical Secretariat to Adjustment, and the Directorate General of Planning are to be continued. In order to harmonize indicators among all actors, a committee will be set up to harmonize the choice of the indicators and to validate their costing. This committee will be consisted of representatives from INSTAT, the Managing Director of Planning, the Technical Secretariat to Adjustment and the Ministries that are involved (Health, Education, MEFB).

Regarding enterprises data collection,, collaboration with the Chairpersons of the private sector is needed.

As regard financing, the needs must be considered in accordance with the actions programmed under the monitoring of the PRSP implementation and advocacy actions have to be conducted among technical and financial partners. 


\section{CONCLUSION}

In the course of the last three years, the implementation of the PRSP left its mark in the area of the planning and the programming process by bringing in a number of innovations in terms of conducting the development of the country,, by combining PARTICIPATION - PARTNERSHIP and RESULTS.

After two years and a half of PRSP implementation, the following paradigms are worth highlighting:

1. The PRSP process enabled a noticeable and tangible increase in Madagascar PHYSICAL and HUMAN CAPITAL, because many results and achievements were obtained in the country as a whole. Physical and economic infrastructures are spreading and their development contributes gradually to smooth down the deficits and imbalances inside and between regions.

2. Nevertheless, despite many achievements, the poverty reduction strategy which was conducted during the exercise was not usually in favor of poor people because the fruit of growth was rather gathered by those who do not immediately need it, and this was due to a lack of a fairly rigorous targeting process. Such an issue will have to be solved urgently so as to sustain the actions undertaken for those who should really benefit from them.

3. Furthermore, despite the partnership process that was engaged, it seems that the private sector contribution as a leverage for development remains relatively weak in spite of its effort in some privileged areas and sectors.

It is obvious that the assets of the PRSP process will be capitalized and improved within the framework of the Madagascar Action Plan (MAP) process, which will start in 2007. It is a question of improving:

- the analysis of the public policies

- the macro-economic policy in the medium term that supports the objectives of development

- the development and the coordination of the programs in order to improve their effectiveness

- the requirement assessment in means and costing

- the priority of the governmental actions by considering the means and the risks of extreme shocks

- the clarification of the institutional arrangements of the monitoring and evaluation system , and

- the reinforcement of the institutional capacities as regards budget process (development, execution, control) at the central, regional and commune level 


\section{ERRATA}

Table 15: Social Sector specific Indicators

The following indicators, specific to health and education sectors will be monitored in the same way as the first 31 indicators

\begin{tabular}{|c|c|c|c|c|c|c|c|c|}
\hline Subprogram & Interim indicators & $\begin{array}{c}\text { Achievement } \\
2003\end{array}$ & $\begin{array}{c}2004 \\
\text { Objective }\end{array}$ & $\begin{array}{c}\text { Achievement } \\
2004\end{array}$ & $\begin{array}{c}2005 \\
\text { Objective }\end{array}$ & $\begin{array}{c}\text { Achievement } \\
2005\end{array}$ & $\begin{array}{c}2006 \\
\text { Objective }\end{array}$ & $\begin{array}{c}2007 \\
\text { Objective }\end{array}$ \\
\hline \multirow{10}{*}{$\begin{array}{l}\text { Fundamental } \\
\text { education }\end{array}$} & $\begin{array}{l}\begin{array}{l}\% \text { of } 6 \text { year old enrolled children } \\
\text { in }\end{array} \quad \text { primary/fundamental } \\
\text { education }\end{array}$ & 80.0 & 81.0 & 94.0 & 94.0 & 94.0 & 94.0 & 94.0 \\
\hline & \begin{tabular}{|ll} 
MENRES budget share \\
allocated to EPPs (in \%)
\end{tabular} & 53.0 & 58.0 & 54.3 & 60.0 & 64.0 & 67.0 & 66.0 \\
\hline & \multirow{2}{*}{$\begin{array}{l}\text { MENRES budget execution } \\
\text { Non salary recurrent } \\
\text { Capital expenditures } \\
\end{array}$} & 97.4 & 95.0 & 93.15 & 93.0 & & 95.0 & 95.0 \\
\hline & & 93.7 & 95.0 & 84.8 & 90.0 & & 92.0 & 92.0 \\
\hline & \multirow{3}{*}{$\begin{array}{l}\text { Repetition percentage: public + } \\
\text { private in \% } \\
\text { Public + private in \%. urban } \\
\text { Public + private in \%. rural } \\
\end{array}$} & 29.0 & 22.0 & 29.9 & 19.0 & 18.2 & 15.0 & 12.0 \\
\hline & & 20.0 & 19.0 & 17.5 & 11.0 & & 8.0 & 6.0 \\
\hline & & 32.0 & 29.0 & 31.4 & 27.0 & & 15.0 & 12.0 \\
\hline & \multirow{3}{*}{$\begin{array}{l}\text { Pupil/ teacher ratio in all Public } \\
\text { primary schools } \\
\text { The whole } \\
\text { urban } \\
\text { rural }\end{array}$} & 59 & 57 & 56 & 56 & 60.0 & 54 & 53 \\
\hline & & 46 & 46 & & 49 & & 48 & 46 \\
\hline & & 60 & 58 & & 56 & & 54 & 53 \\
\hline \multirow{11}{*}{ Health } & $\begin{array}{l}\text { Drug availability rate in CSBs in } \\
\% \\
\text { Chloroquine or equivalent }\end{array}$ & 89.9 & 95.0 & 96.0 & 90.0 & 56.091 .7 & 90.0 & 90.0 \\
\hline & \multirow{4}{*}{$\begin{array}{l}\text { FAF or equivalent } \\
\text { Cotrimoxazole or equivalent } \\
\text { Paracetamol or equivalent } \\
\text { Vitamin A or equivalent } \\
\end{array}$} & 83.7 & 95.0 & 84.5 & 85.0 & 38.185 .5 & 85.0 & 85.0 \\
\hline & & 83.0 & 95.0 & 94.7 & 90.0 & 56.195 .2 & 90.0 & 90.0 \\
\hline & & 79.4 & 95.0 & 90.6 & 90.0 & 55.291 .2 & 90.0 & 90.0 \\
\hline & & 93.4 & 95.0 & 93.5 & 90.0 & 65.090 .9 & 90.0 & 90.0 \\
\hline & $\begin{array}{l}\text { MSPF budget share allocated to } \\
\text { SSDs (in \%) }\end{array}$ & 53.65 & 44.0 & 54.07 & 44.20 & 54.20 & 55.0 & 56.0 \\
\hline & \multirow{2}{*}{$\begin{array}{l}\text { MSPF Budget execution: } \\
\text { Non salary recurrent } \\
\text { Capital expenditures }\end{array}$} & 95.0 & 70.7 & 83.7 & 85.0 & & 87.0 & 90.0 \\
\hline & & 99.4 & 86.2 & 86.2 & 90.0 & 57.8 & 95.0 & 95.0 \\
\hline & \multirow{2}{*}{$\begin{array}{l}\text { Delivery rate with professional } \\
\text { assistance in all: } \\
\text { Public CSB and CHD 1, in \% } \\
\text { Public CHD 2, in \% }\end{array}$} & 28.04 & 35.0 & 26.10 & 27.10 & 19.723 & 28.5 & 29.9 \\
\hline & & 2.08 & 2.1 & 2.2 & 2.1 & 1.5 & 2.15 & 2.2 \\
\hline & $\begin{array}{l}\text { Medical cure consultation rate in } \\
\text { public CSBs, new case/ year }\end{array}$ & 0.57 & 0.4 & 0.49 & 0.58 & $0,450.41$ & 0.61 & 0.64 \\
\hline
\end{tabular}

Note: Health indicators that are jointly agreed by donors and used in EU/PARP for determining variable tranche. For 2005, the levels are provisional and based on $80 \%$ of CSB and $71.7 \%$ of CHD reporting.

Table 52: Indicators for Health

\begin{tabular}{|c|c|c|c|c|}
\hline \multirow{2}{*}{ Specific objectives } & \multirow{2}{*}{ Indicators } & \multirow{2}{*}{2004} & \multicolumn{2}{|r|}{2005} \\
\hline & & & Objectives & Achievements \\
\hline $\begin{array}{l}\text { Promote Mother } \\
\text { and Child health }\end{array}$ & $\begin{array}{l}\text { Specific/ overall } \\
\text { Maternal mortality rate for } 100,000 \text { living births } \\
\text { Child and infant mortality rate for } 1,000 \text { living } \\
\text { births } \\
\text { DTC, Hepatitis B3 Immunization coverage rate } \\
\text { for children under one year (\%) } \\
\text { Rate of professionally assisted births in CSBs } \\
(\%) \\
\text { Complete immunization rate for children from } 1 \\
\text { to } 11 \text { months }(\%)\end{array}$ & $\begin{array}{l}469(\mathrm{a}) \\
94(\mathrm{~b}) \\
75.1 \\
26,1 \\
53 @\end{array}$ & $\begin{array}{l}285 \\
84,8 \\
84,8 \\
27,1 \\
58,4\end{array}$ & $\begin{array}{l}\text { Non available } \\
\text { Non available } \\
87 \\
19.723 \\
\text { ND }\end{array}$ \\
\hline $\begin{array}{l}\text { Intensify } \\
\text { transmissible } \\
\text { disease prevention }\end{array}$ & Plague lethality rate $(\%)$ & & $<14$ & 8,3 \\
\hline $\begin{array}{ll}\text { Intensify } & \text { non- } \\
\text { transmissible } & \\
\text { disease } & \text { (MNT) } \\
\text { prevention } & \end{array}$ & Number of centers caring for equipped MNT & & 46 & 92 \\
\hline
\end{tabular}




\begin{tabular}{|c|c|c|c|c|}
\hline \multirow{2}{*}{ Specific objectives } & \multirow{2}{*}{ Indicators } & \multirow{2}{*}{2004} & \multicolumn{2}{|c|}{2005} \\
\hline & & & Objectives & Achievements \\
\hline $\begin{array}{lr}\text { Improve } & \text { access to } \\
\text { quality } & \text { health } \\
\text { services } & \end{array}$ & $\begin{array}{l}\text { Specific/ overall } \\
\text { Population ratio for one CSB } \\
\text { Medical cure consultation rate in the CSB } \\
\text { Chloroquine } \\
\text { Iron, folic acid } \\
\text { Cotrimoxazole } \\
\text { Paracetamol } \\
\text { Vitamin A } \\
\text { Medical prescription execution rate in the CSB } \\
\text { Number of functional public CSB } \\
\text { - } 1 \text { new international hospital } \\
3 \text { CHR operational } \\
2 \text { CHD2 operational } \\
5 \text { welcoming, sorting-out and emergency } \\
\text { (centers) operational, } 23 \text { dentistry offices } \\
30 \text { CSB equipped } \\
80 \% \text { poor have access to free Medicare (list set } \\
\text { by communes) }\end{array}$ & $\begin{array}{l}1 / 5612 \\
49 \\
96 \\
84,5 \\
94,7 \\
90,6 \\
93,5 \\
\\
85,5 \\
2383\end{array}$ & $\begin{array}{l}1 / 7523 \\
58 \\
90 \\
85 \\
90 \\
90 \\
90 \\
\\
90 \\
2266 \\
\end{array}$ & $\begin{array}{l}\text { Non available } \\
4541 \\
5691.7 \\
38.185 .5 \\
56.195 .2 \\
55.291 .2 \\
6590.9 \\
\\
88,2 \\
\\
\\
30 \% \\
\\
75 \% \\
100 \% \\
100 \% \\
+ \text { de } 100 \% \\
60 \% \\
100 \%\end{array}$ \\
\hline $\begin{array}{l}\text { Improve } \\
\text { performance } \\
\text { health system }\end{array}$ & $\begin{array}{l}\text { Specific } \\
\text { CSB1 and CSB2 staff coverage rate (\%) } \\
\text { Intermediate } \\
\text { SSD allocated MPSF budget share (\%) } \\
\text { recurrent non salary } \\
\text { Capital expenditures } \\
\text { PGE } \\
\text { National health program approved }\end{array}$ & $\begin{array}{l}54,07 \\
83,7 \\
86,2\end{array}$ & $\begin{array}{l}100 \\
44,20 \\
85 \\
90\end{array}$ & $\begin{array}{l}92 \\
54,20 \\
92,56 \\
57,8 \\
100 \%\end{array}$ \\
\hline
\end{tabular}

(a, b, c) source EDS 2003/2004

Objectives and achievements (Non available) Next survey in 2009: maternal mortality rate reduced to 36285 for 100,000 living births, infant and juvenile mortality rate reduced to 7284.8 for 1,000 , complete immunization coverage rate at $7558.4 \%$, Plague lethality rate to be replaced by tuberculosis prevalence rate because tuberculosis is a chronic disease prevailing all over the country, whereas plague prevails in 41 SSD foci, poverty index, in relation with HIVIAIDS 